\title{
Konwergencja gospodarcza w Polsce \\ i jej znaczenie w osiąganiu celów polityki spójności
}


$\frac{3}{40}$ 


\section{Ewa Kusideł}

\section{Konwergencja gospodarcza w Polsce \\ i jej znaczenie w osiagganiu celów polityki spójności}

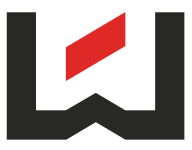

WYDAWNICTWO

UNIWERSYTETU

ŁÓDZKIEGO

ŁÓDŹ 2013 
Ewa Kusideł - Katedra Ekonometrii Przestrzennej, Wydział Ekonomiczno-Socjologiczny Uniwersytet Łódzki, 90-214 Łódź, ul. Rewolucji 1095 r. nr 39

\author{
RECENZENT \\ Elżbieta Sobczak \\ SKŁAD, ŁAMANIE, EDYCJA TEKSTU \\ Emilia Modranka
}

PROJEKT OKŁADKI

Adam Suchecki

(C) Copyright by Uniwersytet Łódzki, Łódź 2013

Wydane przez Wydawnictwo Uniwersytetu Łódzkiego

Wydanie I (dodruk). W.06208.13.0.H

ISBN 978-83-7525-877-6

Wydawnictwo Uniwersytetu Łódzkiego

90-131 Łódź, ul. Lindleya 8

www.wydawnictwo.uni.lodz.pl

e-mail: ksiegarnia@uni.lodz.pl

tel. (42) 66558 63, faks (42) 6655862

Druk i oprawa: Quick Druk 


\section{SPIS TREŚCI}

WSTĘP

CZĘŚĆ I. KONWERGENCJA GOSPODARCZA. ZAGADNIENIA TEORETYCZNE, METODOLOGICZNE I APLIKACYJNE

ROZDZIAŁ 1. KONWERGENCJA GOSPODARCZA. DEFINICJE, ŹRÓDŁA, RODZAJE

1.1. Spór o konwergencję i dywergencję gospodarczą w świetle teorii ekonomicznych $\quad 16$

1.2. Neoklasyczna teoria wzrostu gospodarczego a konwergencja 20

1.2.1. Funkcje produkcji typu Cobba-Douglasa i stabilne stany równowagi 24

1.3. Rodzaje konwergencji gospodarczej 26

1.3.1. Konwergencja PKB per capita i WDB na pracującego 26

1.3.2. Konwergencja technologiczna 29

1.3.2.1. Ustalenie wartości zmiennych i parametrów w formule TFP 32

1.3.2.2. Potencjalne i efektywne TFP 34

$\begin{array}{ll}\text { 1.3.2.3. Endogenizacja TFP } & 35\end{array}$

1.3.3. Konwergencja sektorowa 36

1.3.4. Konwergencja wewnętrzna i hipoteza Williamsona 39

1.4. Podsumowanie 42

ROZDZIAŁ 2. RODZAJE KONWERGENCJI WEDŁUG METOD

2.1. Konwergencja typu beta 46

2.1.1. Empiryczna weryfikacja hipotezy o beta-konwergencji dla danych przekrojowych 47

2.1.2. Empiryczna weryfikacja hipotezy o beta-konwergencji dla danych panelowych $\quad 50$

2.2. Konwergencja typu sigma

2.2.1. Miary nierówności $\quad 53$

$\begin{array}{ll}\text { 2.2.2. Weryfikacja hipotezy o sigma-konwergencji } & 60\end{array}$

2.2.3. Zależność pomiędzy beta i sigma-konwergencją oraz efekty przestrzenne 63

2.3. Konwergencja typu gamma 65

2.3.1. Weryfikacja hipotezy o gamma-konwergencji za pomocą testu

Boyle'a-McCathy'ego

2.3.2. Weryfikacja hipotezy o gamma-konwergencji za pomocą modyfikacji testów Boyle'a-McCarthy'ego

2.4. Konwergencja stochastyczna 71

2.4.1. Kointegracja pomiędzy dwoma regionami. Podejście Engle’a i Grangera 72

2.4.2. Kointegracja pomiędzy więcej niż dwoma regionami. Podejście Johansena 73

2.4.3. Postacie modeli VECM i ich wpływ na wnioskowanie o kointegracji $\quad 75$

2.4.4. Testowanie liczby wektorów kointegracyjnych - rzędu kointegracji $\quad 76$

$\begin{array}{ll}\text { 2.5. Podsumowanie } & 77\end{array}$

ROZDZIAE 3. KONWERGENCJA GOSPODARCZA W POLSCE 79

3.1. Dane statystyczne, metodologia pomiaru zmiennych i problemy z tym związane $\quad 80$

3.1.1. PKB per capita i wydajności pracy $\quad 80$

$\begin{array}{ll}\text { 3.1.2. Łączna produktywność czynników produkcji } & 83\end{array}$

$\begin{array}{ll}\text { 3.1.3. Stopy deprecjacji kapitału regionalnego } & 88\end{array}$

$\begin{array}{ll}\text { 3.1.4. Dane sektorowe } & 90\end{array}$

3.2. Konwergencja PKB per capita i WDB na pracującego 93

$\begin{array}{ll}\text { 3.2.1. Beta-konwergencja absolutna i warunkowa } & 93\end{array}$

$\begin{array}{ll}\text { 3.2.2. Sigma-konwergencja } & 98\end{array}$

$\begin{array}{lr}\text { 3.2.3. Gamma-konwergencja } & 102\end{array}$

$\begin{array}{lr}\text { 3.2.4. Konwergencja stochastyczna } & 104\end{array}$ 
3.3. Konwergencja TFP i stany równowagi wojewódzkiej 106

$\begin{array}{ll}\text { 3.3.1. Beta konwergencja absolutna i warunkowa } & 107\end{array}$

3.3.2. Sigma-konwergencja 110

$\begin{array}{ll}\text { 3.3.3. Gamma-konwergencja } & 111\end{array}$

3.3.4. Wyznaczenie stanów równowagi wojewódzkiej 113

$\begin{array}{ll}\text { 3.4. Konwergencja sektorowa } & 117\end{array}$

3.4.1. Ocena poziomu rozwoju województw przy wykorzystaniu sektorowej struktury $\begin{array}{ll}\text { pracujących } & 117\end{array}$

3.4.2. Konwergencja struktury pracujących w 4 sektorach gospodarki $\quad 120$

3.4.3. Konwergencja wydajności pracy w 4 sektorach gospodarki 125

$\begin{array}{lr}\text { 3.4.4. Konwergencja TFP w } 4 \text { sektorach gospodarki } & 128\end{array}$

$\begin{array}{ll}\text { 3.5. Podsumowanie } & 132\end{array}$

\section{CZEŚĆC II. POLITYKA SPÓJNOŚCI I JEJ WPLYW NA SYTUACJE
GOSPODARCZĄ WOJEWÓDZTW I ICH KONWERGENCJE}

ROZDZIAŁ 4. PROCESY KONWERGENCJI GOSPODARCZEJ W EUROPIE I NA ŚWIECIE WOBEC REALIZACJI POLITYKI SPÓJNOŚCI

4.1. Konwergencja gospodarcza na świecie i w Europie $\quad 137$

4.2. Polityka spójności jako odpowiedź na rosnące nierówności gospodarcze w UE 145

$\begin{array}{ll}\text { 4.3. Konwergencja regionalna i wewnętrzna } & 147\end{array}$

4.3.1. Hipoteza Williamsona i konwergencja wewnętrzna 148

4.4. Realizacja polityki spójności w Polsce 152

4.4.1. Transfery z UE do Polski na realizację polityki spójności 153

4.4.2. Alokacje wojewódzkie transferów z polityki spójności 155

$\begin{array}{ll}\text { 4.5. Podsumowanie } & 157\end{array}$

ROZDZIAŁ 5. EWALUACJA POLITYKI SPÓJNOŚCI 159

$\begin{array}{ll}\text { 5.1. Metody ewaluacji polityki spójności } & 160\end{array}$

5.1.1. Przegląd modeli wykorzystywanych w Europie do ewaluacji polityki spójności 162

5.1.1.1. Historia, opis i zastosowania wybranych modeli 164

5.1.1.2. Wybór modelu do ewaluacji polityki spójności 166

5.1.2. Przegląd makromodeli stosowanych w ewaluacji polityki spójności w Polsce $\quad 168$

5.2. Rola czynników demograficznych w analizie wpływu polityki spójności 170

$\begin{array}{lr}\text { 5.3. Kryteria ewaluacyjne } & 172\end{array}$

$\begin{array}{ll}\text { 5.4. Podsumowanie } & 175\end{array}$

ROZDZIAŁ 6. WPŁYW POLITYKI SPÓJNOŚCI NA GOSPODARKI WOJEWÓDZTW I ICH KONWERGENCJĘ

6.1. Zmiany we wskaźnikach monitorujących politykę spójności w okresie po akcesji do Unii - efekt brutto

6.2. Wpływ polityki spójności na wskaźniki gospodarcze wg makromodeli gospodarki stosowanych w Polsce do ewaluacji funduszy

$\begin{array}{lr}\text { 6.3. Wpływ polityki spójności na polskie regiony i ich konwergencję } & 182 \\ \text { 6.3.1. Trafność } & 183\end{array}$

$\begin{array}{ll}\text { 6.3.2. Użyteczność } & 186\end{array}$

$\begin{array}{lr}\text { 6.3.3. Skuteczność } & 188\end{array}$

$\begin{array}{lr}\text { 6.3.4. Efektywność } & 190\end{array}$

$\begin{array}{lr}\text { 6.4. Podsumowanie } & 193\end{array}$

$\begin{array}{ll}\text { ZAKOŃCZENIE } & 195\end{array}$

$\begin{array}{ll}\text { BIBLIOGRAFIA } & 201\end{array}$

$\begin{array}{lr}\text { WYKAZ OZNACZEŃ } & 215\end{array}$ 


\section{WSTĘP}

Pojęcie konwergencji w sensie używanym w tej książce narodziło się z neoklasycznych teorii wzrostu (lata 50. i 60. XX wieku), w których to konwergencja oznaczała proces wyrównywania dochodów (produktów per capita) pomiędzy krajami. Najbardziej intensywne, światowe badania konwergencji przypadają na lata 80. i 90. XX wieku, natomiast w Polsce temat ten stał się popularny wraz z akcesją do Unii w 2004 r., od kiedy Polska jest beneficjentem polityki spójności - polityki regionalnej Unii Europejskiej, dążącej do podwyższenia poziomu spójności gospodarczej, społecznej i terytorialnej.

Badania nad konwergencją są ważne $\mathrm{z}$ wielu powodów, z których najważniejszy jest wymiar społeczno-gospodarczy. Współczesny świat cechuje bowiem silne rozwarstwienie dochodów, które zapoczątkowane zostało wraz $\mathrm{z}$ industrializacją w XIX w. Ówczesne różnice pomiędzy najzamożniejszymi i najbiedniejszym gospodarkami są dziś kilkakrotnie większe. Duże dysproporcje są obserwowane nie tylko pomiędzy krajami, ale również wewnątrz poszczególnych państw; gospodarki w których mieszkają najbogatsi mieszkańcy świata, to często kraje o najwyższym odsetku ludzi żyjących na granicy ubóstwa. Tak duże różnice w poziomach dochodów powodują silne dysproporcje w poziomach życia oraz niepokoje społeczne i wydają się, z czysto ludzkiego punktu widzenia, niesprawiedliwe.

Odpowiedź na pytanie o przyczyny tak dużego rozwarstwienia dochodowego na świecie badacze próbują znaleźć w teoriach wzrostu gospodarczego, stąd następny asumpt do podejmowania badań nad konwergencją - wyniki badań dostarczają argumentów do rozstrzygnięcia sporu naukowego co do czynników i konsekwencji wzrostu gospodarczego. Wg szkoły neoklasycznej i modelu Solowa konwergencja jest zjawiskiem, które jest wynikiem wzrostu gospodarczego. Inaczej twierdzą zwolennicy teorii wzrostu endogenicznego, którego konsekwencją może być przeciwne zjawisko - dywergencja. W niektórych źródłach uważa się, że stwierdzenie występowania zjawiska konwergencji jest potwierdzeniem słuszności założeń Solowa, a stwierdzenie, że konwergencja nie występuje przemawia za poprawnością teorii wzrostu endogenicznego.

Badania nad konwergencją są w Polsce ważne są również z praktycznego punktu widzenia. Otóż Polska zobowiązana jest do rozliczenia efektów płatności przekazywanych przez Komisję Europejską na realizację polityki spójności. Głównym celem tej polityki jest zmniejszanie nierówności gospodarczych wśród regionów-beneficjentów. W Polsce wszystkie regiony NUTS $2^{1}$ są objęte

\footnotetext{
${ }^{1} \mathrm{~W}$ literaturze przedmiotu funkcjonują różne definicje regionu. W pracy tej rozumiany jest on jako obszar NUTS 2 zdefiniowany wg europejskiej Klasyfikacji Jednostek Terytorialnych do Ce-
} 
pierwszym celem tej polityki o nazwie „Konwergencja”. Tymczasem wiele badań wskazuje, że o ile w Polsce zachodzą procesy konwergencji zewnętrznej (rozumianej jako proces gospodarczego doganiania średnich dla UE), to nie zachodzą procesy konwergencji wewnętrznej (rośnie zróżnicowanie gospodarcze wewnątrz kraju). Generalnie, spójność regionalna, która była normą do późnych lat 70. jest coraz trudniejsza do osiągnięcia, a współczesną Unię Europejską charakteryzuje następująca rozbieżność - malejące nierówności dochodowe w stosunku do średnich UE, przy jednoczesnym rosnącym rozwarstwieniu wewnątrz krajów. Stosunkowo konsyliacyjnym wyjaśnieniem tego ostatniego faktu jest hipoteza Williamsona mówiąca o tym, że wewnątrzkrajowe nierówności gospodarcze są przejściowe i tylko w początkowym etapie doganianie (nazywane w literaturze przedmiotu efektem catch-up) ma postać specjalizacji, polaryzacji i regionalnego zróżnicowania ${ }^{2}$. Bardziej pesymistyczny punkt widzenia przedstawiają inni autorzy (np. Boldrin i Canova [2001], Puga [2002]) twierdząc, że alokacja inwestycji w najgorzej rozwiniętych regionach (tzw. podejście wyrównawcze) jest nieefektywnym i utrudniającym doganianie procesem, a wspierane regiony wykazują niezdolność do samodzielnego wzrostu po wstrzymaniu pomocy zewnętrznej. Dyskusja nad rolą polityki spójności w osiąganiu konwergencji jest trzecim powodem podjęcia badań nad tym zjawiskiem - wyniki analiz mogą stanowić źródło wiedzy dla aktorów sceny politycznej odpowiedzialnych za decyzje o modelu finansowania polityki spójności.

\section{Obszar badawczy i zakres danych statystycznych}

Pisząc $w$ tej pracy o konwergencji domyślnie przyjęto jej wymiar gospodarczy, której oznaką jest zmniejszanie dysproporcji w miernikach aktywności gospodarczej takich jak PKB per capita. Tymczasem zagadnienie konwergencji można rozszerzyć na wiele innych płaszczyzn życia. W szczególności realizowana w ramach polityki regionalnej UE polityka spójności, dąży do podwyższania poziomu nie tylko spójności gospodarczej, ale również społecznej i terytorialnej (przestrzennej). Praca niniejsza dotyczy jedynie konwergencji gospodarczej (o społecznym i przestrzennym wymiarze konwergencji autorka pisała w innych swoich pracach).

\footnotetext{
lów Statystycznych NUTS (Nomenclature of Units for Territorial Statistics). Poziom NUTS 2 służy identyfikacji obszarów kwalifikujących się do wsparcia w ramach polityki spójności (obszary problemowe o niskim poziomie rozwoju).

${ }^{2}$ Co tłumaczy się tym, że w początkowych stadiach rozwoju powiązania międzyregionalne, przepływ czynników produkcji oraz centralna polityka władz działają selektywnie na korzyść ośrodków i centrów dobrze rozwiniętych. Natomiast stały wzrost dochodów per capita, przyczynia się do odwrócenia trendu w kolejnych stadiach (por. Gawlikowska-Hueckel, Zielińska-Głębocka, [2004, s.223]).
} 
W celu oceny, czy w Polsce zachodzi szeroko pojęta konwergencja gospodar$\mathrm{cza}^{3}$ przeprowadzono w rozdziale 3 . wiele badań, w których przedmiotem oceny były procesy gospodarcze mierzone wskaźnikami opartymi o PKB per capita, wydajność pracy (wartość dodaną brutto na pracującego) i TFP (łączną produktywność czynników produkcji). Podmiotem oceny było 16 polskich województw. Analiza obejmowała okres 1995-2010 (lub, jak w przypadku niektórych analiz sektorowych, 1995-2009). Dolny zakres czasowy jest najwcześniejszym okresem dla którego można prowadzić w Polsce badania dla podziału wojewódzkiego zgodnego z europejską klasyfikacją NUTS 2. Rok końcowy 2010 - jest ostatnim, dla którego były dostępne dane $\mathrm{z}$ rachunków regionalnych.

Przedmiotem oceny w drugiej części pracy (której celem jest ocena wpływu realizacji polityki spójności na konwergencję) są procesy gospodarcze mierzone wskaźnikami opartymi głównie o PKB per capita oraz PKB per capita, które zrealizowałoby się, gdyby polityka spójności nie była realizowana. Podmiotem oceny jest 16 polskich województw. Analiza obejmuje głównie zakres czasowy 2003-2009. Jego dolna granica wyznaczona jest przez moment akcesji Polski do Unii (rok 2003 jest ostatnim dla którego wskaźniki gospodarcze nie mogą zawierać wpływu realizacji polityki spójności), górna - limitacją danych $\mathrm{z}$ rachunków regionalnych dostępnych $\mathrm{w}$ momencie przeprowadzania obliczeń. Taki zakres czasowy analiz wpływu polityki spójności sprawia, że ewaluacji podlega głównie pierwszy okres jej programowania, którego ramy zostały zapisane w Narodowym Planie Rozwoju 2004-2006.

\section{Cele główne i szczególowe pracy}

Praca składa się z dwóch części. Części pierwszej (którą tworzą rozdziały 1 - 3) przyświecają dwa główne cele:

1) uporządkowanie i sklasyfikowanie różnych rodzajów konwergencji wraz z podaniem możliwych źródeł występowania tego zjawiska,

2) ocena, czy zachodzi proces szeroko pojętej konwergencji gospodarczej wśród polskich województw.

W części drugiej pracy (na którą składają się rozdziały 4 - 6) przeprowadzono badania umożliwiające realizację trzeciego głównego celu pracy:

3) ocenę wpływu realizacji polityki spójności na osiąganie konwergencji gospodarczej przez polskie województwa.

\footnotetext{
${ }^{3}$ Pod nazwą ,szeroko pojętej konwergencji” rozumieć należy zarówno szeroki zestaw zmiennych w stosunku do których stosowano testy konwergencji, jak i duży zakres samych testów konwergencji.
} 
Realizacja powyższych celów wiązała się z odpowiedzią na szereg szczegółowych pytań badawczych, które uporządkowano poniżej wg głównych celów pracy.

1) Uporządkowanie i sklasyfikowanie różnych rodzajów konwergencji wraz z podaniem możliwych źródeł występowania tego zjawiska związane było z odpowiedzią na następujące pytania badawcze:

- Czy istnieje jednoznaczna definicja konwergencji?

- W jakich teoriach ekonomicznych można odnaleźć informacje o źródłach i naturze zjawiska konwergencji?

- Czy różne wnioski co do konwergencji mogą wypływać z przyjęcia innej jej definicji?

- Czy weryfikacja hipotezy o konwergencji za pomocą różnych metod jej pomiaru może prowadzić do przeciwnych wniosków?

2) W celu oceny, czy w Polsce zachodzi proces konwergencji gospodarczej, sformułowano poniższe pytania szczegółowe:

- Jakich mierników aktywności gospodarczej używa się w badaniach konwergencji?

- Czy wojewódzkie PKB per capita oraz wydajność pracy charakteryzuje konwergencja?

- Czy w Polsce zachodzi proces konwergencji technologicznej?

- Czy województwa dążą do wspólnego stanu równowagi gospodarczej i jaki jest im czas potrzebny do jej osiągnięcia?

- Czy parametryzacja modelu Solowa i funkcji produkcji ma wpływ na wnioski o konwergencji?

- Czy podział województw Polski na bardziej homogeniczne grupy zmienia wnioski o występowaniu różnych rodzajów konwergencji gospodarczej?

- Czy wyższy stopień konwergencji występuje na zagregowanym, czy sektorowym poziomie?

- W którym sektorze gospodarki występuje najsilniejsza konwergencja (dywergencja) i jakie są tego przyczyny?

3) Realizacja trzeciego celu pracy: ocenę wpływu realizacji polityki spójności na osiąganie konwergencji w Polsce, wiązała się z odpowiedzią na poniższe pytania badawcze:

- Jak przebiegał proces zwiększania się nierówności gospodarczych na świecie i w Europie?

- Czy osiąganie konwergencji zewnętrznej, przy jednoczesnym zwiększaniu nierówności gospodarczych wewnątrz kraju, jest typową rozbieżnością wśród krajów realizujących politykę spójności? 
- Jakie metody używane są w Polsce i w Europie do ewaluacji polityki spójności?

- W jakim stopniu cele polityki spójności odpowiadają potrzebom poszczególnych województw (kryterium trafności)?

- W których regionach efektywność wsparcia jest największa (kryterium efektywności)?

- Czy oddziaływanie polityki spójności odpowiada potrzebom poszczególnych województw (kryterium użyteczności)?

- Do jakiego stopnia cele polityki spójności zdefiniowane na etapie jej programowania zostały osiągnięte (kryterium skuteczności)?

- Czy realizacja polityki spójności przyczynia się do osłabienia dywergencji gospodarczej polskich województw?

\section{Struktura książki}

Praca składa się ze wstępu, sześciu rozdziałów oraz zakończenia, w którym zawarto główne konkluzje z przeprowadzonych badań. Dodatkowo każdy rozdział opatrzono podsumowaniem, w którym starano się odpowiedzieć na najważniejsze pytania szczegółowe i gdzie zamieszczono wnioski z danego rozdziału.

Rozdział pierwszy ma za zadanie wprowadzić czytelnika w tematykę konwergencji - dlatego znalazły się w nim definicje różnych rodzajów tego zjawiska, jego źródła, mierniki oraz podstawy teoretyczne wraz z nakreśleniem idei sporu naukowego, który toczy się wśród zwolenników i przeciwników konwergencji. $\mathrm{Na}$ uwagę w tym rozdziale zasługuje część, która wskazuje, że parametryzacja modelu służącego do oceny konwergencji może wpływać na uzyskiwane wnioski o jej występowaniu, część dotycząca roli postępu technologicznego w osiąganiu konwergencji oraz podsumowanie, w którym dokonano sklasyfikowania różnych definicji konwergencji.

Rozdział drugi porządkuje rodzaje konwergencji wg różnych metod jej weryfikacji. Zawarto w nim szeroką gamę narzędzi weryfikujących różne rodzaje konwergencji: typu beta, sigma, gamma, a także konwergencji stochastycznej. Ta ostatnia zasługuje na szczególną uwagę, z powodu rzadkości badań tego typu w Polsce, jak i faktu stosowania metodologii wektorowych modeli korekty błędem (dla których zaproponowano dodatkowe, poza wskazaniami literaturowymi, przeznaczenie w badaniach konwergencji). W rozdziale drugim podano również bardzo wyczerpującą listę miar zróżnicowania i koncentracji zjawisk, którą uzupełniono o miary szczególnie użyteczne w badaniach w podziale na sektory gospodarki (wykorzystywane w statystyce i ekonometrii przestrzennej). Wydaje się, że brak jest innej pozycji w polskiej literaturze przedmiotu, która przedstawiałaby równie wyczerpujący zestaw narzędzi do pomiaru i weryfikacji zjawiska konwergencji, szczególnie, że jest on uzupełniony o autorskie modyfikacje niektórych wzorów i testów. 
W rozdziale trzecim znajdują się analizy konwergencji gospodarczej w Polsce. Ze względu na rozliczne przykłady badania konwergencji dochodowej (na podstawie PKB per capita) - poświęcono temu zagadnieniu stosunkowo mało uwagi. Skupiono ją na badaniach innych zmiennych, w szczególności łącznej produktywności czynników produkcji - TFP. Zwrócono uwagę na konsekwencje, jakie dla szacunków TFP może mieć parametryzacja wyjściowej funkcji produkcji, jak i uwzględnienie innej definicji zmiennych i współczynników stosowanych w obliczaniu kapitału regionalnego. Na uwagę w rozdziale trzecim zasługują również badania sektorowe, które pokazały, że procesy konwergencji w sektorach gospodarki (rolnictwa, przemysłu, usług rynkowych i nierynkowych) przebiegają inaczej niż na poziomie zagregowanym. Sektorowe badania konwergencji: frakcji pracujących, wydajności pracy oraz łącznej produktywności czynników produkcji nie były jeszcze w Polsce prowadzone, a w każdym razie nie na taką skalę (użyto większości opisywanych w rozdziale drugim testów konwergencji) - dlatego ich wyniki stanowią nowy wkład w literaturę przedmiotu. Przeprowadzone w rozdziale trzecim badania pozwoliły odpowiedzieć na wszystkie pytania szczegółowe związane z realizacją drugiego głównego celu pracy: oceny, czy wśród województw Polski zachodzi proces szeroko pojętej konwergencji.

Rozdział czwarty, piąty i szósty składają się na drugą część pracy, dotyczącą wpływu realizowanej w Polsce polityki spójności na konwergencję - co nadaje pracy praktyczny wymiar, bowiem uzyskane wyniki mogą być wykorzystane przez odpowiednie władze jako wkład do ewaluacji polityki spójności w Polsce, jak i jako argument do dyskusji nad przyszłością tej polityki. Przeprowadzone w tej części badania (w szczególności z rozdziału 6) pozwoliły odpowiedzieć na pytania związane z trzecim głównym celem pracy - w szczególności o trafność, użyteczność, skuteczność i efektywność realizowanej w Polsce polityki spójności. 


\section{Część I}

\section{KONWERGENCJA GOSPODARCZA. ZAGADNIENIA TEORETYCZNE, METODOLOGICZNE, APLIKACYJNE}





\section{ROZDZIAL 1 \\ KONWERGENCJA GOSPODARCZA. DEFINICJE, ŹRÓDŁA, RODZAJE}

Pojęcie konwergencji stało się popularne w krajach, które zobowiązano do wypełnienia kryteriów konwergencji zawartych w traktacie z Maastricht ${ }^{1}$, co jednocześnie doprowadziło do pewnej polisemii tego zjawiska. Kryteria konwergencji zawarte w traktacie z Maastricht dotyczyły grupy warunków (dotyczących stabilności cen, wahań kursów walutowych, poziomów stóp procentowych, stabilnej sytuacji finansów publicznych w szczególności w sferze deficytu budżetowego), jakie musi spełnić kraj, aby przystąpić do Unii Walutowej. Tymczasem konwergencja o której mowa w tej pracy, oznacza, najogólniej mówiąc, proces upodabniania się do siebie badanych gospodarek (regionów, krajów) i wywodzi się od (ang., fr.) convergence ${ }^{2}$, co oznacza dosłownie zbieżność (jak i tworzenie się jakichś zbieżności) lub spójność ${ }^{3}$.

Jak widać konwergencja w rozumieniu kryteriów z Maastricht i konwergencja gospodarcza, o której mowa w tej książce to dwa różne zjawiska, nazywane $\mathrm{w}$ literaturze przedmiotu konwergencja nominalna i realną. Pierwsza oznacza spełnienie przez kraje pewnych (wspomnianych powyżej) nominalnych warunków określonych w traktacie z Maastricht. Drugi rodzaj konwergencji dotyczy realnych procesów gospodarczych, których analiza jest celem niniejszej pracy.

Intensywne badania nad zjawiskiem konwergencji realnej w latach 80. XX w. oraz późniejszych doprowadziły do zdefiniowania wielu jego typów i odmiennych sposobów weryfikacji. W literaturze przedmiotu wymienia się konwergencje typu beta, sigma, gamma, a ostatnio stochastyczną, konwergencję społeczną, przestrzenną, dochodową, technologiczną, sektorową, klubową i inne. Różnorodność definicji i metod pomiaru zjawiska konwergencji skłania do refleksji nad samym pojęciem, jego źródłami, rodzajami i metodami badania. Uporządkowaniu i sklasyfikowaniu tych pojęć został poświęcony niniejszy rozdział (następny porządkuje rodzaje konwergencji ze względu na metody jej weryfikacji).

\footnotetext{
${ }^{1}$ Traktat o Unii Europejskiej (Traktat z Maastricht) z 1992 r.

2 Por. Uniwersalny Stownik Języka Polskiego [2008, s. 232], Stownik Języka Polskiego [1978, t.1, s. 1004].

${ }^{3}$ Choć najstarsza etymologia tego pojęcia pochodzi ze średniowiecznołacińskeigo, gdzie convergo oznaczało sktaniać się ku czemuś (por. Stownik wyrazów obcych [1980, s.389]). Obecnie pojęcie konwergencji funkcjonuje w wielu innych, poza ekonomią, dziedzinach nauki (ewolucji, politologii, biologii, medycynie, etnografii). Ekonomiczna geneza tego terminu jest związana z debatą nad teorią systemów ekonomicznych z lat pięćdziesiątych i sześćdziesiątych, gdzie problemem spornym była kwestia, czy pomiędzy systemem kapitalistycznym i socjalistycznym zachodzi proces upodabniania się czy też nie (por. Brelik, Grzelak [2011]).
} 


\subsection{Spór o konwergencję i dywergencję gospodarczą w świetle teorii ekonomicznych}

A. Gerschenkron, profesor Universytetu Harvarda w połowie XX w. sformułował model spóźnionego rozwoju gospodarczego i koncepcje zacofania, w których jedną z tez jest to, że w warunkach względnego zacofania możliwe jest gwałtowne przyspieszenie rozwoju (efekt doganiania: catch-up effect ${ }^{4}$ ). Empirycznym poparciem tej tezy były dane statystyczne pokazujące, że w niektórych krajach słabo rozwiniętych wskaźniki wzrostu gospodarczego były wyższe niż w krajach wysoko rozwiniętych, co doprowadziło do wyrównania poziomów gospodarczych wśród krajów ${ }^{5}$. Podobne implikacje wynikają z modelu Solowa [1956], a późniejszy rozwój teorii wzrostu gospodarczego polegał w dużej mierze na weryfikacji głównej implikacji modelu Solowa dla wzrostu, czyli efektu doganiania gospodarek o wyższym poziomie dochodu przez gospodarki znajdujące się początkowo na niższym poziomie dochodu. Tego rodzaju zależność (ujemna korelacja pomiędzy początkową wartością cechy a jej tempem wzrostu) jest weryfikowana w ramach najbardziej popularnej hipotezy o konwergencji (tzw. beta-konwergencji - por. p. 2.1). Fakty empiryczne pokazywały jednakże, że konwergencja taka nie zawsze zachodzi, a nowe teorie wzrostu - szczególnie teoria wzrostu endogenicznego - wskazywały na możliwość wystąpienia przeciwnej konsekwencji wzrostu gospodarczego - dywergencji ${ }^{6}$. Spór o konwergencję rozgrywa się głównie pomiędzy szkołą neoklasyczną a endogenicznego wzrostu i dotyczy roli czynników produkcji (praca, kapitał, wiedza), które w modelu Solowa są egzogeniczne, a w modelu wzrostu endogenicznego są generowane przez badany system (endogeniczne $)^{7}$.

Zgodnie z neoklasyczną teorią wzrostu, warunkiem koniecznym do zaistnienia konwergencji między badanymi obszarami (krajami, regionami) są malejące produktywności krańcowe kapitału. Oznacza to, że różnice pomiędzy obszarami zmniejszają się, bowiem te biedniejsze, konkurując niższymi cenami i kosztami, przyciągają inwestycje. Inaczej mówiąc spadająca produktywność w regionach

\footnotetext{
${ }^{4} \mathrm{~W}$ niektórych popularnych źródłach internetowych, konwergencja jest utożsamiana z efektem catch-up (doganiania). Biorąc jednakże pod uwagę różne rodzaje konwergencji, o których jest mowa w rozdziale drugim, efekt ten należy połączyć z konwergencją typu beta.

${ }^{5}$ Por. http://www.economicprincipals.com/issues/2005.04.24/145.html, pobrane 07.05.2012).

${ }^{6}$ Choć są opinie (por. Carree, Klomp [1997, s. 686]), że poszukiwania w kierunku modeli wzrostu endogenicznego wynikające $\mathrm{z}$ braku konwergencji w modelach neoklasycznych mogą być wynikiem stosowania w stosunku do tych drugich procedur, które są obciążone popełnieniem błędu II rodzaju (odrzucaniem hipotezy o konwergencji podczas, gdy jest ona prawdziwa).

${ }^{7}$ Choć Sala-i-Martin [1996, s. 1345-1347] przywołuje również przykłady modeli wzrostu endogenicznego, które potwierdzają hipotezę o konwergencji oraz pokazuje, jak możliwe rozszerzenia modelu Solowa: o endogenizację stopy oszczędności, stopy deprecjacji, stopy wzrostu populacji (zatrudnienia) wpływają na konwergencję.
} 
bogatszych skłania przedsiębiorców do realokacji kapitału do regionów o mniejszych jego zasobach - w celu podniesienia wydajności produkcji. Prowadzi to do wyrównywania się kapitału (i kapitału na zatrudnionego) pomiędzy krajami (regionami), co przy założeniu podobnego zaawansowania technologicznego ${ }^{8}$ powoduje wyrównywanie produkcji (produkcji na zatrudnionego) a więc konwergencję.

Ferment w tak pojmowanym mechanizmie konwergencji wywołała teoria wzrostu endogenicznego oraz przedstawiciele Nowej Geografii Ekonomicznej. Stosowana w teorii wzrostu endogenicznego rozszerzona (o kapitał ludzki) definicja kapitału godziła w prawo malejących przychodów. Najnowszy wkład do dyskusji za i przeciw konwergencji prezentują teoretycy regionalnej aglomeracji, na czele z P. Krugmanem - twórcą Nowej Geografii Ekonomicznej ${ }^{9}$. Prace Krugmana dostarczyły nowych argumentów do dyskusji o czynnikach wzrostu, z których wynika, że w układach regionalnych możliwa jest zarówno konwergencja, jak i dywergencja. Na przykład różnice w płacach mogą sprzyjać konwergencji poprzez lokalizację produkcji w regionach o niższych kosztach pracy - to tradycyjne podejście do teorii lokalizacji przedsiębiorstw. Z drugiej strony wzajemne powiązania przedsiębiorców stymulują innowacje, a powstające w ten sposób technologie są zasadniczym źródłem rosnącej krańcowej produktywności kapitału (czemu dodatkowo sprzyjają lepiej rozwinięta infrastruktura oraz bliskość odbiorców, kooperantów, lepiej wykwalifikowana siła robocza). Ostatecznie, w niektórych sytuacjach można mieć do czynienia nie z malejącymi (jak to postuluje teoria neoklasyczna), lecz rosnącymi przychodami skali. Dopuszczenie ich istnienia stwarza teoretyczne podstawy samonapędzającego się procesu rozwoju gospodarczego, który skupia aktywność ekonomiczną wokół dużych ośrodków miejskich - metropolii ${ }^{10}$. Czy możliwa jest w takich warunkach konwergencja? Tak, ale nie (tylko) jako konsekwencja akumulacji kapitału, lecz (również) jako konsekwencja dyfuzji innowacji i technologii.

\footnotetext{
${ }^{8} \mathrm{O}$ roli zaawansowania technologicznego w teoriach ekonomicznych traktuje osobny podrozdział (1.3.2)

${ }^{9}$ Paul Krugman został w 2008 r. uhonorowany Nagrodą Nobla za analizę wzorów handlowych i lokalizacji działalności gospodarczej, w której wyjaśniał, dlaczego w międzynarodowej wymianie handlowej dominują nie tylko kraje o podobnych warunkach, ale także te handlujące zbliżonymi produktami.

10 Koncepcja rosnących przychodów skali została sformułowana przez Myrdala [1944] już w pierwszej połowie XX wieku. Zakładała ona, że proces wzrostu gospodarczego ma charakter kumulatywny, tzn. po osiągnięciu pewnego krytycznego poziomu aktywności ekonomicznej, ośrodek metropolitalny może rozwijać się coraz szybciej dzięki występowaniu sprzężeń zwrotnych (por. Spójność wewnętrzna a konkurencyjność..., [2009], s. 15). Gorzelak [2008, s. 77] podkreśla, że obserwowana ostatnio metropolizacja rozwoju, wynika z koncentrowania się segmentu produkcji i usług o wysokim zaawansowaniu technologicznym w największych miastach, bowiem inne regiony nie są w stanie sprostać wymaganiom takiego segmentu.
} 
Teoretycznie, tempo dyfuzji zależy od wielkości luki technologicznej - w miarę zmniejszania się luki technologicznej jej dalsze ograniczanie staje się coraz trudniejsze (por. Kudełko [2011, s. 30]). Oznaczałoby to łatwość doganiania przez obszary o najniższym zaawansowaniu technologicznym. Lecz nieprzygotowanie otoczenia biznesu (warunki, które można nazwać wspólnym mianem socjopolitycznych o których szerzej napisano na początku podrozdziału 1.3.2) może ostatecznie znacząco ograniczać absorpcję innowacji, a w konsekwencji konwergencję.

Ostatecznie, spór o konwergencję nie jest na gruncie teorii ekonomii rozstrzygnięty, natomiast w różnych koncepcjach można doszukać się pewnej gamy czynników sprzyjających konwergencji, jak i takich, które ten proces utrudniają lub uniemożliwiają. Do pierwszej grupy należą:

- prawo malejących przychodów (ta sama ilość kapitału zainwestowana w gospodarce o niższym kapitale początkowym daje wyższy zwrot niż w gospodarce o początkowo wyższym kapitale, czemu sprzyja małe zaawansowanie technologiczne regionów zacofanych gospodarczo - ułatwiające zwiększanie tego potencjału w regionach uboższych),

- możliwość imitowania już istniejących technologii, co jest znacznie tańsze niż opracowywanie nowych (w modelu Solowa długookresowy wzrost zależy, podobnie jak w modelu wzrostu endogenicznego, od postępu technologicznego, różnica dotyczy źródeł - egzogenicznych lub endogenicznych tego zjawiska),

- przekształcenia strukturalne i segmentacja gospodarki - struktura sektorowa gospodarki ma wpływ na konwergencję (por. Boldrin, Cannova [2001]), podobnie do jej segmentacji (por. Gorzelak [2007]), zgodnie z którą w segmentach gospodarczych o niskim poziomie innowacyjności i zaawansowania technicznego i niskich kosztach produkcji konwergencja jest bardziej prawdopodobna (w sektorach tych można spodziewać się przewag komparatywnych - ze względu na dążenie do minimalizacji kosztu produkcji można oczekiwać przenoszenia kapitału pomiędzy regionami),

- teoria wymiany międzynarodowej Heckeshera-Ohlina-Samuelsona, wg której mobilność czynników wytwórczych (doprowadzająca do wyrównywania się krańcowych produktów pracy) oraz wymiana handlowa (doprowadzająca do wyrównywania się cen) sprzyja zmniejszaniu różnic w poziomie płac i dochodów (zgodnie z tą teorią integracja europejska powinna mieć pozytywny wpływ na spójność gospodarczą).

Z drugiej strony funkcjonują hipotezy głoszące, że osiąganie konwergencji nie jest konsekwencją wzrostu gospodarczego (lub ma inne podłoże niż początkowo sądzono albo wręcz jest niemożliwe). Wśród tych argumentów należy przywołać: 
- prawo rosnących przychodów, które wg badaczy wywodzących się ze szkoły keynesowskiej, a także Nowej Geografii Ekonomicznej (por. Krugman [1991]) dotyczy w szczególności nakładów na badania i rozwój; nowe teorie wzrostu (endogenicznego) uchylają prawa malejących przychodów z zastosowanego kapitału (kapitał fizyczny rozszerzony o kapitał ludzki i wiedzę nie musi dostarczać malejących przychodów),

- nierównomierne rozłożenie bogactw naturalnych dających przewagę ekonomiczną krajom o większym dostępie do bogactw, a jeśli były one położone na obszarach państw kolonizowanych - rabunkową eksploatację tych zasobów (często też kraje kolonialne służyły jedynie za rynek zbytu i źródło taniej siły roboczej),

- teorię kumulatywnego uwarunkowania, zgodnie z którą zacofanie, jak i rozwój, uwarunkowane są pozycją wyjściową danego kraju, która ma tendencję do utrwalania się. Jest to zjawisko nazywane również "pułapką biedy", polegające na niedoskonałości otoczenia społecznego lub instytucjonalno-infrastrukturalnego, z powodu którego niemożliwe jest efektywne przetwarzanie sygnałów płynących z rynku (np. brak właściwego otoczenia biznesu, brak uregulowań prawno-instytucjonalnych, korupcja, zbyt wysoka dzietność, powodująca „rozcieńczenie” kapitału pracy ${ }^{11}$ ),

- przekształcenia strukturalne i segmentację gospodarki - w wysokich segmentach gospodarczych (o wysokim poziomie innowacyjności i zaawansowania technicznego tj. działalność badawczo-rozwojowa) bardziej prawdopodobna jest koncentracja niż konwergencja (ze względu na konieczność wystąpienia określonych warunków dla rozwoju innowacji, które mogą zaistnieć w miejscach już wysoko rozwiniętych (por. Gorzelak [2008, s.77], Kusidel [2010a]),

- teorię wymiany międzynarodowej, która wymieniona była wśród czynników ułatwiających konwergencję, lecz jeśli wymiana nie opiera się na sprawiedliwych kryteriach (kiedy to kraje zacofane otrzymują relatywnie przestarzałe technologie, a lokowanie zasobów nowoczesnych związane jest z utrzymaniem praw do nich przez liderów), to pomimo pewnych początkowych korzyści z transferu kapitału i technologii, może to utrwalać zacofanie (por. Fiedor, Kociszewski [2010]).

\footnotetext{
${ }^{11}$ Zjawisko to nosi nazwę pułapki malthusiańskiej i streszcza je anglosaskie przysłowie: „każdym ustom towarzyszy para rąk, ale nie zawsze ręce te wytworzą więcej, niż skonsumują usta".
} 


\subsection{Neoklasyczna teoria wzrostu gospodarczego a konwergencja}

Efekt doganiania, oznaczający osiąganie przez obszary biedniejsze wyższych stóp wzrostu gospodarczego niż kraje bogatsze, leżący u podstaw najbardziej klasycznie pojętej (beta) konwergencji, sugeruje silne powiązanie tego procesu ze wzrostem gospodarczym. Modelem wzrostu gospodarczego wyjaśniającym zjawisko konwergencji gospodarczej jest model Solowa [1956] (czasami łączony również z nazwiskiem Swana [1956]) oraz związana z nim neoklasyczna teoria wzrostu gospodarczego, która stanowiła w swoim czasie próbę odpowiedzi na pytanie o czynniki długookresowego wzrostu gospodarczego. Wg szkoły neoklasycznej konwergencja jest zjawiskiem będącym naturalną konsekwencją wzrostu gospodarczego, bowiem w warunkach malejącej krańcowej produktywności kapitału (która jest jednym z założeń modelu Solowa) w miarę dochodzenia gospodarki do długookresowej równowagi - długookresowa stopa wzrostu produkcji będzie asymptotycznie malała. W związku z malejącą krańcową produktywnością kapitału, przepływa on do krajów (regionów), w których jego zasób (w przeliczeniu na mieszkańca lub pracownika) jest mniejszy, czyli do obszarów uboższych. Stąd wyrównywanie poziomów kapitału, co implikuje konwergencję dochodów (produktów) i wydajności pracy. Formalnie rzecz ujmując, opisywany model uzależnia wzrosty produkcji $Y$ od wzrostu trzech czynników ja warunkujących: zatrudnienia $-L$, kapitału $-K$, łącznej produktywności czynników produkcji $-A^{12}$ :

$$
Y_{t}=F\left(A_{t}, K_{t}, L_{t}\right)^{13}
$$

Zasadniczym, dla konwergencji, założeniem modelu Solowa jest warunek malejącej produktywności krańcowej, który określa, że powyższa funkcja produkcji jest rosnąca, lecz z malejącymi kolejnymi przyrostami. Oznacza to że w miarę przyrostu $K$ (przy stałości pozostałych czynników ${ }^{14}$ ), przyrosty $Y$ są coraz mniejsze. Podstawowe znaczenie dla wzrostu ma zatem zmiana kapitału w gospodarce, która jest równa:

$$
K_{t}=K_{t-1}+I_{t}-\delta K_{t-1}=(1-\delta) K_{t-1}+I_{t}
$$

\footnotetext{
${ }^{12}$ Łączna produktywność czynników produkcji (TFP - Total Factor Productivity) jest syntetycznym sposobem oceny zmian efektywności procesów produkcyjnych, zachodzących pod wpływem postępu technicznego, dlatego czasem zamiennie używa się terminów TFP i postęp technologiczny (techniczny) - o czym szerzej traktuje podrozdział 1.3.2.

${ }^{13} \mathrm{~W}$ całej książce $t$ jest indeksem czasu. Jest on czasami pomijany we wzorach w niniejszym rozdziale, lecz zawsze obecny.

${ }^{14}$ Załóżmy, że zatrudnienie $(L)$ i technologia $(A)$ rosną ze stałą stopą równą odpowiednio $n, g$.
} 
stąd:

$$
K_{t}-K_{t-1}=I_{t}-\delta K_{t-1} \rightarrow \Delta K=I_{t}-\delta K_{t-1}
$$

gdzie: $K$ jest, jak powyżej, miarą kapitału (który się zużywa z pewną stopą deprecjacji $\delta$ ), a $I$ miarą inwestycji (o miarach tych szerzej traktuje rozdział 1.3.2).

Równanie (1.2.3) pokazuje, że zmiana kapitału (inwestycji netto - por. Barro [1997]) zależy od relacji inwestycji faktycznych (brutto) - I, pomniejszonych o amortyzację - $\delta K$ (inwestycji odtworzeniowych, restytucyjnych). Sala-i-Martin [1996, s. 1343] nazywa wykres inwestycji faktycznych - krzywą oszczędności (która przecina się z krzywą deprecjacji), co wynika z założenia modelu Solowa, że inwestycje równają się oszczędnościom, które z kolei są pewną częścią (równą stopie oszczędności $s$ ) produkcji: $s Y=I$. Biorąc pod uwagę te założenia, równanie (1.2.3) można zapisać jako:

$$
\Delta K_{t}=s Y_{t}-\delta K_{t}=s F\left(A_{t}, K_{t}, L_{t}\right)-\delta K_{t}
$$

Punkt równowagi w modelu Solowa można zatem wyprowadzić z równania akumulacji kapitału, w którym kapitał zmienia się poprzez: zasób kapitałowy $(K)$, strumień kapitałowy $(I)$ oraz deprecjację $(\delta)$, co zobrazowano na rysunku 1.2.1 (pokazującym punkt równowagi w modelu Solowa w wersji uproszczonej $\left.{ }^{15}\right)$.

\footnotetext{
${ }^{15} \mathrm{~W}$ wersji uproszczonej zakłada się, że jedynie zmiana kapitału powoduje zmianę produkcji, czyli zatrudnienie $(L)$ i technologia $(A)$ nie zmieniają się. W wersji pośredniej zmianie ulega dodatkowo (oprócz kapitału) zatrudnienie, przy niezmiennej technologii, a w wersji rozszerzonej modelu Solowa wzrost produkcji zależy od zmian wszystkich czynników wzrostu gospodarczego wymienionych we wzorze (1.2.4): kapitału, pracy i postępu technologicznego. Założenia te będą powodowały, że linia inwestycji odtworzeniowych opisana na rysunku 1.2.1 jako $\delta K$, będzie opisywana przez $(\delta+n) K$ w wersji pośredniej lub $(\delta+n+g) K$ w wersji rozszerzonej, gdzie $\delta, n, g$ oznacza odpowiednio stopę deprecjacji kapitału, stopę wzrostu zatrudnienia i stopę wzrostu łącznej produktywności czynników produkcji.
} 
Rys.1.2.1. Punkt równowagi w modelu Solowa

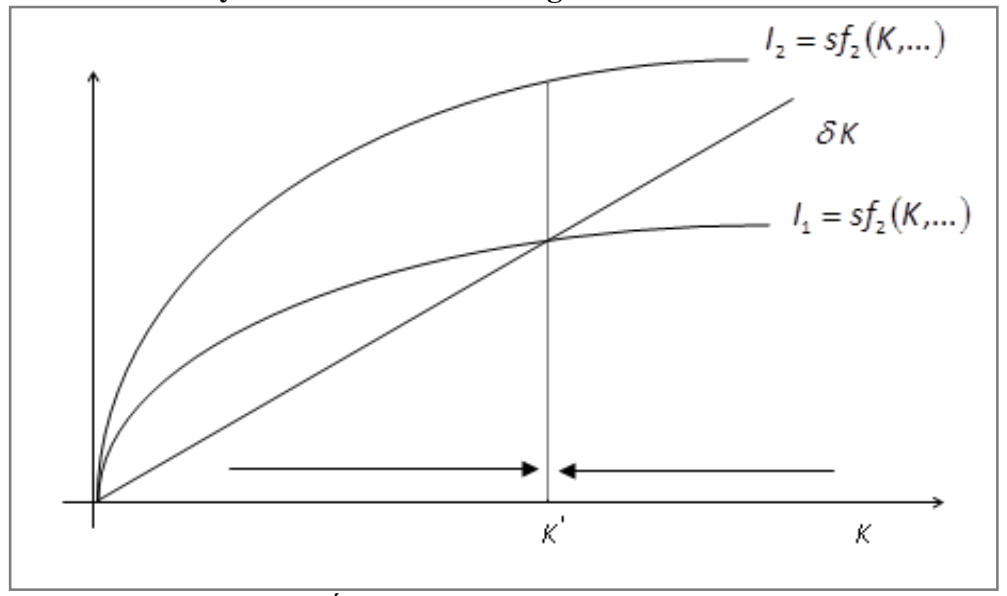

Źródło: opracowanie własne

$\mathrm{Z}$ rysunku 1.2.1 wynika, że jeśli inwestycje faktyczne $I$ będą większe (mniejsze) od odtworzeniowych $\delta K$, to kapitał będzie rósł (malał).W punkcie równowagi, gdy inwestycje faktyczne są równe odtworzeniowym, kapitał nie zmienia się. W przypadku intensywnej wersji funkcji $(1.2 .4)^{16}$ równowaga pojawia się, gdy kapitał na zatrudnionego nie zmienia się. Gdy kapitał na zatrudnionego rośnie (akumulacja kapitału na zatrudnionego), tzn. gdy inwestycje na zatrudnionego są większe od inwestycji odtworzeniowych na zatrudnionego, wtedy rośnie również produkcja. Rosnąca produkcja w następnym okresie powiększa kapitał dzięki wzrostowi oszczędności (lub inwestycji, które są iloczynem produkcji i stopy oszczędności), co z kolei prowadzi do dalszego akumulowania kapitału i dalszego wzrostu produkcji. Proces powiększania produkcji trwa do momentu zrównania inwestycji faktycznych z odtworzeniowymi: $I=\delta K$, potem przyrosty produkcji są mniejsze niż przyrosty kapitału, co jest manifestacją głównego założenia modelu Solowa - malejącej produktywności krańcowej. A zatem założenie o malejącej produktywności kapitału powoduje, że przy tych samych stopach oszczędności i dostępie do identycznej technologii, kraje o niższym nasyceniu kapitału powinny rozwijać się szybciej niż kraje o wysokim jego nasyceniu i ostatecznie kraje biedne będą, przeciętnie biorąc, wzrastały szybciej niż bogate (por. Barro, [1997, s. 304]). Im niższa będzie początkowa wartość kapitału (im wcześniejsza faza rozwoju gospodarki), tym wyższa stopa wzrostu produktu ${ }^{17}$. Szybkość, z którą opóźnione obszary będą doganiać bardziej rozwinięte zależy od:

\footnotetext{
${ }^{16}$ Założenie o stałych korzyściach skali pozwala na przedstawienie funkcji w formie intensywnej, tzn. na jednego pracownika $(L)$ lub na jednostkę pracy efektywnej $(A L)$.

${ }^{17}$ Niska wartość kapitału na zatrudnionego sugeruje również wysoki krańcowy produkt kapitału i związaną z nim wysoką realną stopę procentową $-r$. W podręczniku Barro [1997, rozdział 9]
} 
a) spadku nachylenia krzywej $I=s f(K, \ldots)$ - jeśli krzywa szybko zmienia swój kształt na bardziej płaski $\left(I_{1}\right)$, to szybkość, z jaką przy danej liczbie pracujących (i innych czynnikach) zaczyna działać prawo malejących przychodów, jest większa (im wyższa elastyczność produkcji względem kapitału, tym później osiągany jest stan równowagi, a dla elastyczności rzędu 1, krzywa ta staje się prostą i brak jest punktu przecięcia - nie ujawnia się działanie prawa malejących przychodów);

b) kąta nachylenia linii inwestycji odtworzeniowych, który zależy od stopy deprecjacji kapitału $\delta$, tempa wzrostu pracujących $n$ oraz stopy wzrostu postępu technicznego $g$ - im mniejsze wartości tych stóp, tym ostrzejszy kąt tworzy prosta $\delta K$ (lub w wersji rozszerzonej $(\delta+n+g) K$ ) i tym szybciej nastąpi przecięcie z krzywą $I=s f(K, \ldots)^{18}$.

Ostatecznie, z powyższych rozważań wynika związek pomiędzy parametrami modelu Solowa a konwergencją. Otóż szybkość konwergencji zwiększa się wraz ze wzrostem stopy deprecjacji $-\delta$, tempa wzrostu pracujących (liczby ludności) - $n$ i tempa wzrostu postępu technologicznego $-g$ oraz maleje wraz ze wzrostem elastyczności produkcji względem kapitału $-\alpha^{19}$ :

$$
\beta=(\delta+n+g)(1-\alpha)
$$

pokazano, że inwestorzy przyrównują krańcowy produkt kapitału do $r+\delta$. Wynika z tego, że w miarę podwyższania kapitału, i co za tym idzie zmniejszania jego produktu krańcowego, realne stopy procentowe powinny maleć.

${ }^{18}$ W podręczniku Barro [1997, s. 307] można przeczytać, że „właczenie postępu technicznego wplywa na niektóre wnioski dotyczace konwergencji. Podstawowa nowa myśl sprowadza się do spostrzeżenia, że stopa wzrostu na 1 mieszkańca jest wysoka nie wtedy, gdy Y/L jest niskie w sensie absolutnym, lecz wówczas, gdy Y/L dzieli duża odległość od zmiennego w czasie $(Y / L)^{*}$ [gdzie $(Y / L)^{*}$ oznacza wydajność pracy w stanie równowagi - przyp. aut.]. Dla grup krajów o takiej samej funkcji produkcji (oraz takich samych $\delta$ i $s$ ) z modelu nadal wynika, że produkt na 1 mieszkańca w krajach o niższej produkcji na 1 mieszkańca będzie róst szybciej. Proces uczenia się i przyswajania nowoczesnej techniki jest kolejnym mechanizmem umożliwiającym uboższym zakatkom globu doganianie zamożniejszych".

${ }^{19}$ Przy założeniach stałych korzyści skali (a takie założenie jest rozsądne, jeśli możemy wykluczyć ziemię jako istotny czynnik produkcji - por. Barro [1997, s. 302]), ustalone wielkości produkcji na zatrudnionego i kapitału na zatrudnionego są niezależne od wielkości zatrudnienia. 


\subsubsection{Funkcje produkcji typu Cobba-Douglasa i stabilne stany równowagi}

Najczęściej wykorzystywaną postacią funkcji produkcji w modelu Solowa jest funkcja Cobba-Douglasa postaci ${ }^{20}$ :

$$
Y_{t}=A_{t} K_{t}^{\alpha} L_{t}^{(1-\alpha)}
$$

lub w postaci funkcji wydajności pracy (po podzieleniu obu stron równania przez $\left.L_{t}\right)$ :

$$
y_{t}=A_{t} k_{t}^{\alpha}
$$

gdzie: $K_{t}$ - kapitał fizyczny, $L_{t}$-zatrudnienie, $Y_{t}$ - produkcja, $\alpha$ - elastyczność produkcji względem kapitału, $y_{t}$ - produkcja na zatrudnionego (wydajność pracy), $k_{t}$ - kapitał na zatrudnionego (techniczne uzbrojenie pracy), $A_{t}-$ zmienna reprezentująca postęp technologiczny (o sposobach pomiaru tych zmiennych szerzej traktuje podrozdział 1.3.2).

Inkorporując funkcję produkcji Cobba-Douglasa daną równaniem (1.2.1.1) do równania przyrostu kapitału z modelu Solowa postaci (1.2.4) otrzyma się następujące równanie:

$$
\Delta K_{t}=s Y_{t}-\delta K_{t}=s\left(A_{t} K_{t}^{\alpha} L_{t}^{(1-\alpha)}\right)-\delta K_{t}
$$

które można zapisać w przeliczeniu na zatrudnionego:

$$
\Delta k_{t}=s y_{t}-(\delta+n) k_{t}=s\left(A_{t} k_{t}^{\alpha}\right)-(\delta+n) k_{t}
$$

lub w postaci stopy wzrostu kapitału na zatrudnionego:

$$
\frac{\Delta k_{t}}{k_{t}}=\frac{s\left(A_{t} k_{t}^{\alpha}\right)}{k_{t}}-(\delta+n)
$$

gdzie: $s, \delta, n$ - oznacza, podobnie jak we wzorze (1.2.5), stopę oszczędności (inwestycji), stopę deprecjacji kapitału oraz tempo wzrostu zatrudnienia ${ }^{21}$.

\footnotetext{
${ }^{20} \mathrm{~W}$ równaniu pomijamy składnik losowy.

${ }^{21}$ Podobny wzór (por. np. Sala-i-Martin [1996, s. 1342]) można zastosować do kapitału per capita (zamiast na pracującego), zastępując stopę wzrostu zatrudnienia - stopą wzrostu liczby ludności (por. przypis nr 33).
} 
W przypadku badań konwergencji przedmiotem specjalnego zainteresowania są wartości, kiedy to dynamika produkcji (produkcji na zatrudnionego) jest zerowa. Zgodnie z założeniem modelu Solowa stan równowagi, czy inaczej mówiąc stan ustalony (w anglosaskiej literaturze mówi się o tzw. steady-state ${ }^{22}$ ) występuje wówczas, gdy stopy wzrostu produkcji są zerowe. Taki poziom kapitału fizycznego na pracującego $k_{t}{ }^{*}$ wynosi ${ }^{23}$ :

$$
k_{t}^{*}=\left(\frac{A_{t} s}{n+\delta}\right)^{\frac{1}{1-\alpha_{i}}}
$$

Podstawienie powyższej wartości do równania (1.2.1.2) wyznacza stan równowagi dla wydajności pracy:

$$
y_{t}^{*}=A_{t}\left(\left(\frac{A_{t} s}{n+\delta}\right)^{\frac{1}{1-\alpha}}\right)^{\alpha}=A_{t}\left(\frac{A_{t} s}{n+\delta}\right)^{\frac{\alpha}{1-\alpha}}
$$

Z powyższych wzorów wynika, że stan równowagi rośnie w czasie wraz ze wzrostem stopy oszczędności (inwestycji) i wzrostem postępu technicznego oraz spada wraz ze wzrostem stopy deprecjacji. W powyższym wzorze, postęp technologiczny zmienia się w czasie, co oznacza, że stan równowagi również zmienia się w czasie - rośnie wraz ze wzrostem $A_{t}$ (por. Barro [1997, s. 306, rysunek 11.5]) . Jeśli uznaje się, że postęp techniczny jest stały w czasie (jak np. w pracy Kliber, Malaga [2007, s.36]), wówczas powyższe wzory można zapisać w postaci (statycznych) stanów równowagi ${ }^{24}$ :

$$
k^{*}=\left(\frac{A s}{n+\delta}\right)^{\frac{1}{1-\alpha}}
$$

\footnotetext{
${ }^{22} \mathrm{~W}$ polskiej wersji podręcznika Barro [1997, s. 635] steady-state thumaczy się jako stan ustalony (i definiuje jako sytuację, w której stopa wzrostu gospodarki wynosi zero, a zasób kapitału, produkt, konsumpcja, inwestycje brutto i nakłady pracy są stałe).

${ }^{23}$ Por. Malaga, Kliber [2007, s. 36].

${ }^{24}$ Lecz jak podkreśla w swoim podręczniku Barro [1997, s. 306] wprowadzenie regularnych usprawnień technicznych polega właśnie na tym, że nie wyznacza się konkretnych wartości stanu ustalonego (jak we wzorach 1.2.1.8 i 1.2.1.9), lecz zamiast tego wartości właściwe dla stanu ustalonego zmieniają się w czasie (jak we wzorach 1.2.1.6 i 1.2.1.7). Regularne usprawnienia techniczne (zmieniający się w czasie postęp technologiczny) sprawia, że zamiast wyznaczania stanu ustalonego (steady-state) wyznacza się ścieżkę stanu ustalonego, którą można nazwać dynamicznym stanem równowagi.
} 


$$
y^{*}=A\left(\frac{A s}{n+\delta}\right)^{\frac{\alpha}{1-\alpha}}
$$

Powracając do polemiki odnośnie do źródeł konwergencji, to ze wzorów (1.2.1.6)-(1.2.1.9) widać, jak ogromną rolę w osiąganiu konwergencji ma postęp technologiczny $(A)^{25}$. To, co powoduje niezgodność pomiędzy zwolennikami neoklasycznego i endogenicznego modelu wzrostu, to nie tyle rola postępu technologicznego w osiąganiu wzrostu, lecz jego źródła. Można powiedzieć, że badacze spierają się o czynniki wypełniające resztę Solowa określoną wzorem (1.3.2.2) lub, mówiąc kolokwialnie, o to czy postęp techniczny można „wziąć z zewnątrz" co zakłada jego egzogeniczna postać w modelu Solowa ${ }^{26}$.

\subsection{Rodzaje konwergencji gospodarczej}

\subsubsection{Konwergencja PKB per capita i WDB na pracującego}

Najczęściej stosowanym miernikiem w badaniach konwergencji gospodarczej jest PKB per capita (PKB pc ${ }^{27}$ ), którego używa się zarówno do badań konwergencji pomiędzy krajami, jak i regionami. Jego popularność wynika z faktu możliwości w miarę obiektywnego porównania dobrobytu obywateli zamieszkujących różne regiony ${ }^{28}$. Ten obiektywizm jest jednak krytykowany z powodu

\footnotetext{
${ }^{25}$ Barro [1997, s. 306] podkreśla, że postęp technologiczny miał „(...) decydujące znaczenie dla dtugookresowego wzrostu na 1 mieszkańca $w$ gospodarce amerykańskiej w ciagu ostatnich dwóch stuleci. Gdyby położenie krzywej produkcji nie uległo zmianom, wówczas działanie prawa malejących przychodów uniemożliwiłoby utrzymanie wzrostu na 1 mieszkańca przez tak długi okres po prostu $w$ drodze wzrostu wielkości kapitatu na 1 zatrudnionego. Postęp techniczny, umożliwiając ucieczkę od nieuchronności tego prawa, pozwala gospodarce wzrastać $w$ kategoriach produktu na 1 mieszkańca, $i$ to nawet $w$ dlugim okresie".

${ }^{26}$ Sala-i-Martin [1996, s. 1344-1345] określa ten spór wprost jako polemikę co do istnienia samego mechanizmu konwergencji - malejącej produktywności czynników produkcji (warunki Inady). Ponieważ modele wzrostu endogenicznego nie zakładają tego mechanizmu, to Sala-i-Martin twierdzi, że hipoteza konwergencji jest $\mathrm{w}$ istocie hipotezą co do istnienia prawa malejących przychodów.

${ }^{27}$ Którego szacunki są oparte o SNA - System of National Account, opublikowane przez ONZ po raz pierwszy w 1952 r. jako zbiór zasad pomiaru wyników pracy społeczeństwa, por. Fiedor, Kociszewski [2010, s. 27].

${ }^{28} \mathrm{~W}$ przypadku porównań międzynarodowych należy zadbać, aby miernik ten miał podobny zakres i sposób mierzenia w poszczególnych krajach, był wyrażony w takiej samej jednostce miary i wyrażał ten sam poziom cen (por. J. Wolszczak-Derlacz [2007, s. 96]). Pierwszy warunek jest spełniony, jeśli do obliczania PKB jest stosowany jeden z dwóch międzynarodowych systemów rachunków narodowych: SNA 93 (System of National Accoutns 1993) lub ESA95 (European System of Accoutns 1995). W celu spełnienia dwóch następnych warunków, PKB przelicza się wg
} 
zawyżenia tej miary na obszarach posiadających silne aglomeracje, do których dojeżdżają do pracy osoby $\mathrm{z}$ innych regionów ${ }^{29}$. W Polsce dotyczy to głównie Warszawy, a w Europie takich aglomeracji jak np. Londyn, Wiedeń, Hamburg, Praga, czy Luxemburg. Krytyka PKB per capita dotyczy również faktu, że nie uwzględnia on negatywnych następstw wzrostu gospodarczego (np. zanieczyszczenia środowiska naturalnego); nie uwzględnia produktów pracy takich osób jak gospodynie domowe oraz produktów niematerialnych jak np. czas wolny; ujmuje koszty społeczne, które nie przyczyniają się do wzrostu dobrobytu, np. wydatki państwa na obronę i administrację. $\mathrm{Z}$ tych względów próbuje się tworzyć alternatywne do PKB per capita mierniki dobrobytu ekonomicznego społeczeństwa, na przykład measure of economic welfare, net economic welfare, Human Development Index ${ }^{30}$.

Pomimo, że nie zawsze można traktować PKB na mieszkańca regionu jako równoważnego dobrobytowi, czy dochodom pierwotnym w regionie, to pozostaje on najpopularniejszą zmienną wykorzystywaną w badaniach konwergencji na szczeblu krajowym i międzynarodowym, a badania oparte o ten miernik nazywane są konwergencja dochodowa.

Ponieważ zwiększanie stopy życiowej jest zależne w długim czasie od wzrostu wydajności pracy, niektórzy autorzy (np. Le Gallo, Dall'erba [2007]) polecają

parytetu siły nabywczej (Purchasing Power Parity) i wyraża w sztucznej walucie zwanej pps (Purchasing Power Standard). Operacja ta pozwala na porównanie siły nabywczej różnych walut krajowych i co za tym idzie na porównania PKB per capita według pps, które jest również kluczową zmienną dla ustalenia kwalifikowalności regionów NUTS $2 \mathrm{w}$ ramach polityki strukturalnej Unii Europejskiej (choć należy pamiętać, że prowadzenie obliczeń w pps zamiast w euro lub rodzimych walutach, może prowadzić do różnic w rankingu regionów - np. w $2008 \mathrm{r}$. dla szwedzkiego regionu Östra Mellansverige PKB per capita wynosiło 30800 EUR, czyli więcej niż w przypadku włoskiego regionu Marche o PKB per capita rzędu 26700 EUR. Jednak w przeliczeniu na pps region Marche miał PKB pc. w wysokości 26500 pps i wyprzedził Östra Mellansverige, w którym PKB pc. wyniosło 26200 pps - por. PKB na poziomie regionalnym, s.3).

${ }^{29}$ Efekt dojeżdżania do pracy powoduje zawyżanie PKB w stolicy i innych dużych miastach, gdzie wielu ludzi pracuje (produkuje), ale nie zamieszkuje, a zaniżania go dla „strefy dojazdowej” lub „regionów sypialni”, por. Łaźniewska i in. [2011, s. 99]. W kontekście badań nad konwergencją w regionach NUTS 2 , o ile efekt ten może zawyżać wartość współczynników zmienności dla PKB per capita, to nie powinien wpływać istotnie na jego rozkład w czasie (należy sądzić, że nawet jeśli zmienność ta jest zawyżona, to podobny efekt występuje w każdym punkcie czasowym). Bardziej istotny jest inny mechanizm, nazwijmy go - demograficzny. W analizowanym okresie zwiększyła się zmienność liczby ludności w Polsce, głównie za sprawą zwiększonego zróżnicowania liczby osób najmłodszych i najstarszych.

${ }^{30}$ Mierniki te są jednak najczęściej nieużyteczne w przypadku badań na poziomie regionalnym (które są prowadzone w tej pracy) ze względu na braki w danych statystycznych, dlatego nie omówiono ich szerzej (o sposobie konstrukcji niektórych z nich można przeczytać w pracy Fiedor, Kociszewski [2010, s. 27-41], zaś w pracy Kusideł [2013a] podjęto próbę konstrukcji regionalnych Human Development Index). 
stosowanie wydajności pracy, a nie PKB per capita, jako podstawowego miernika w badaniach konwergencji gospodarczej. Pomiar konwergencji za pomoca wydajności pracy nazywany jest czasami konwergencją technologiczną, choć częściej takim mianem nazywa się badania oparte o łączną produktywność czynników produkcji. Ponieważ istotą konwergencji technologicznej jest pomiar poziomu technologicznego zaawansowania jako czynnika odpowiedzialnego za gospodarczą zbieżność, wzorem pracy Bernarda i Jonesa [1996] oraz Islama [2003], termin konwergencja technologiczna został zarezerwowany w tej pracy dla badań w oparciu o łączą produktywność czynników produkcji-TFP.

Powracając do badań konwergencji opartych o wydajność pracy (TFP zostanie omówione bardziej szczegółowo w następnym podrozdziale) najprecyzyjniej określa je anglosaski termin productivity convergence i w pracy tej, w celu uniknięcia możliwych nieporozumień zastosowano wierne thumaczenie tego zwrotu: konwergencja wydajnościowa (produktywnościowa) lub konwergencja wydajności pracy (produktu na zatrudnionego) pomimo pewnej niezręczności językowej w takim sformułowaniu tego terminu.

Badania na podstawie wydajności pracy (liczonej w tej pracy jako wartość dodana brutto na pracującego) mają tutaj pracy praktyczne znacznie: zapewnienia porównywalności z wynikami badań sektorowych dla których zastosowanie mierników w przeliczeniu na mieszkańca jest nieuzasadnione ${ }^{31}$. Dodatkowymi argumentami stosowania wydajności pracy jest, że zmienna ta nie jest obarczona takim, jak w przypadku PKB per capita, prawdopodobieństwem przeszacowania na obszarach aglomeracyjnych ${ }^{32}$ oraz jest bezpośrednią konsekwencją

\footnotetext{
${ }^{31}$ Wiele badań pokazuje (zob. podpunkt 1.3.3), że konwergencja na poziomie zagregowanym jest silniejsza niż w sektorach gospodarki. Aby wiarygodnie porównywać takie badania, należy na poziomie zagregowanym i sektorowym stosować ten sam miernik.

${ }^{32}$ Choć może tu wystąpić inny problem, wynikający z metodologii szacowania wartość dodanej brutto - WDB (która jest podstawą szacunków wydajności pracy), polegającej na metodzie jednostek lokalnych rodzajów działalności (zob. Produkt Krajowy Brutto...[dowolne wydanie]). W uproszczeniu sprowadza się ona do tego, że wypracowany przez przedsiębiorstwo produkt przypisuje się faktycznej lokalizacji jego wytworzenia, a nie lokalizacji siedziby przedsiębiorstwa. Siedziby lub centra zarządcze zlokalizowane w metropoliach, pełniące funkcje usługowe najwyższego rzędu o charakterze decyzyjnym, kierowniczym, zarządczym, czy kontrolującym, potrzebują do tego wysoko kwalifikowanej kadry (kapitału ludzkiego). Można założyć, że kapitał ludzki w metropoliach, nawet jeśli nie bierze bezpośrednio udziału w wypracowaniu WDB, to poprzez transfer wiedzy, technologii, innowacji itp. ma swój udział w WDB całego przedsiębiorstwa (bez względu na lokalizację filii). Tymczasem jeśli lokalizacja jego wytworzenia leży poza aglomeracją, to wartość ta nie jest ujmowana w rachunkach dla niej. Ostatecznie wartość produktu wytworzonego w metropolii jest $\mathrm{w}$ przeliczeniu na pracowników z wyższym wykształceniem niższa niż faktyczny ich udział w tym procesie - por. Kusideł [2010a].
} 
stosowania funkcji produkcji w której liczba pracujących (a nie mieszkańców) jest jednym z czynników produkcji ${ }^{33}$.

\subsubsection{Konwergencja technologiczna}

Dyskusja o przyczynach i występowaniu konwergencji gospodarczej dotyczy w szczególności źródeł postepu technologicznego i roli jaką pełni on we wzroście gospodarczym. W modelu Solowa postęp technologiczny jest egzogeniczny i może być „przenoszony” pomiędzy gospodarkami. Zwolennicy teorii neoklasycznej i wynikającej z niej naturalnej konwergencji na poparcie tej tezy przytaczają następujące argumenty: po pierwsze zaawansowanie technologiczne uzbrojenia pracy w regionach najuboższych jest początkowo niskie (najpierw należy je nasycić kapitałem, potem technologią), po drugie, w warunkach zwiększania tego zaawansowania, można zawsze odpowiednie technologie imitować (czego przykładem są „,azjatyckie tygrysy”, które rozwój swoich gospodarek oparły na transferze technologii z krajów zachodnich), co jest znacznie tańsze i mniej czasochłonne niż ich „odkrywanie”. Inaczej twierdzą zwolennicy teorii wzrostu endogenicznego argumentując, że luka technologiczna pomiędzy krajami (regionami) wysoko i nisko rozwiniętymi jest zbyt duża, aby mogły ją pokonać kraje zacofane. Teoretycznie zatem możliwe jest zastosowanie istniejących już technologii, lecz w praktyce proces ten może być zaburzony przez warunki socjopolityczne ${ }^{34}$. Zakładając zatem nawet, że stosowana technologia jest mobilna, to otoczenie biznesu i struktury społeczne mogą nie być gotowe, aby je przejąć (bowiem wymaga to np. wprowadzenia uregulowań prawnych, czy nawet zmian kulturowych ${ }^{35}$ ). W szczególności tempo przejmowania nowych technologii zależy od zdolności absorpcyjnych kraju (regionu) naśladującego, które z kolei zależą od jakości instytucji badawczych i edukacyjnych oraz środowiska biznesowego i politycznego (por. Kudełko [2011, s. 30], Parente, Prescot [2003], Gorzelak [2008]). Podsumowując, przeciwnicy naturalnej konwergencji twierdzą, że postępu technologicznego nie da się po prostu przenieść z bogatszego obszaru do biedniejszego (czy to na skutek dyfuzji, czy imitacji),

\footnotetext{
${ }^{33}$ Co prawda w długim okresie czasu zmiany liczby pracujących wynikają ze zmian liczby ludności (por. Barro [1997, s. 304]), lecz jest to ciągle przybliżenie i trudno mówić o długim okresie w przypadku badań obejmujących kilka lub kilkanaście lat.

${ }^{34}$ Ciekawy przykład podają Parante i Prescott [1999] - Indian, których znacznie niższa (od Amerykanów) produktywność wynika właśnie z niewykorzystanej wiedzy i technologii, które teoretycznie są dla nich dostępne, lecz w praktyce są nieużywane.

${ }^{35}$ C. Udry [1996] pokazuje konkretny przykład nieefektywnego wykorzystania pól uprawnych w Afryce, który można ulepszyć przez prostą realokację zasobów między polami uprawianymi przez kobiety i mężczyzn, co prowadziłoby do wzrostu wydajności pracy. Nie pozwala na to jednakże sztywna struktura społeczna.
} 
bowiem nie tyle jest on czynnikiem, co rezultatem wzrostu gospodarczego i zależy od szeroko rozumianej polityki gospodarczej.

Bez wątpienia postęp technologiczny jest motorem nowej gospodarki ${ }^{36}$, której cechą jest koncentracja na zasobach niematerialnych, a szczególnie na kapitale intelektualnym. Tym samym głównym wyznacznikiem wartości w nowej ekonomii staje się wiedza (wartość ekonomiczna powstaje w procesie tworzenia, dystrybucji i konsumpcji wiedzy oraz produktów opartych na wiedzy) $)^{37}$, czy ogólniej zasoby niematerialne ${ }^{38}$ (intangible resources), które, oprócz wiedzy, obejmują innowacyjność i technologie informacyjne, ale również kulturę organizacyjną, reputację przedsiębiorstwa, marki produktów, kreatywność i przedsiębiorczość, sieć relacji, prawa do własności intelektualnej, kapitał intelektualny, kapitał społeczny, kapitał strukturalny, informację i bazy danych, umiejętności i doświadczenie, stosunki międzyludzkie w organizacji, zaufanie i wiarygodność, lojalność, zdolności, postawy i zaangażowanie (por. Bryan, Kay [1999, s.102], Głuszek [2004, s. 235], Kostro [2005, s. 3], Stobińska [2004, s. 33]).

Tak szeroko zdefiniowane efekty działania postępu technologicznego są niemożliwe do skwantyfikowania. Dlatego na użytek tej pracy postęp technologiczny zdefiniowano jako zmiany $w$ technologii i organizacji produkcji prowadzące do zwiększania efektywności procesów gospodarowania (por. Dańska [2012]), zaś jako syntetyczny miernik oceny tych zmian przyjęto wzrost łącznej produktywności czynników produkcji (TFP - Total Factor Productivity). Poniżej przyjęto, że postęp technologiczny jest utożsamiany ze wzrostem TFP (co zawęża znacznie definicję postępu technologicznego, ale też pozwala go jednoznacznie skwantyfikować), zaś badania konwergencji przy pomocy tej zmiennej nazywane są konwergencja technologiczna ${ }^{39}$.

\footnotetext{
${ }^{36}$ Określenie nowa gospodarka łączone bywa z takimi terminami jak nowy ład ekonomiczny, nowa era, gospodarka wiedzy (lub GOW - gospodarka oparta na wiedzy), gospodarka elektroniczna, gospodarka sieciowa, nowa ekonomia czy ekonomia wiedzy. Postęp technologiczny wywołuje również zespół zjawisk i zależności nie tylko o charakterze ekonomicznym, ale i kulturowym (por. Glińska-Neweś [2007, s.16]), choć te zmiany są bardzo trudne do skwantyfikowania i nie są przedmiotem badań w niniejszej pracy.

${ }^{37}$ Por. Harris [2001, s. 21].

${ }^{38}$ Pojawiają się nawet opinie, że cechą nowej ekonomii w funkcjonowaniu przedsiębiorstw jest to, że tradycyjne czynniki produkcji - ziemia, praca, kapitał - stają się raczej zasobami hamującymi niż napędzającymi, centralnym zaś i kluczowym zasobem staje się wiedza (por. Knosala [2004, s. 282]), choć z drugiej strony niektóre badania pokazują (por. Pawłowski [2005]), że współczesne organizacje wykorzystują zaledwie 10-20\% posiadanej wiedzy i 10-15\% kapitału intelektualnego.

${ }^{39} \mathrm{~W}$ celu empirycznej weryfikacji hipotezy konwergencji technologicznej (rozumianej jako przyczyna wyrównywania się poziomów produktu per capita) stosuje się również podejście, gdzie technologia nie występuje explicite, lecz jej oceny wpływu dokonuje się na podstawie typowej
} 
W pracy niniejszej TFP wyliczane jest na podstawie przekształcenia równania funkcji produkcji typu Cobba-Douglasa (por. podrozdział 1.2.1) do postaci:

$$
T F P_{t}=\frac{Y_{t}}{K_{t}^{\alpha} L_{t}^{(1-\alpha)}}
$$

lub w postaci temp wzrostu $(\Delta)$, tzw. reszty Solowa:

$$
\Delta \ln T F P_{t}=\Delta \ln Y_{t}-\left(\alpha \Delta \ln K_{t}+(1-\alpha) \Delta \ln L_{t}\right)
$$

gdzie: TFP - łączna produktywność czynników produkcji, $K_{t}$-kapitał fizyczny, $L_{t}$ - zatrudnienie, $Y_{t}$ - produkcja, $\alpha$ - elastyczność produkcji względem kapitahu.

Podczas wyliczania TFP pojawia się szereg problemów, bowiem właściwie każdy element powyższych wzorów stanowi kwestię do decyzji badacza. Sam miernik produkcji $(Y)$, nawet jeśli uznamy, że jest to wartość dodana brutto (jak przyjęto $\mathrm{w}$ badaniach $)^{40}$, pozostawia do rozstrzygnięcia, czy mają to być wartości faktyczne, czy potencjalne (por. podrozdział 1.3.2.1). Podobny dylemat dotyczy wielkości pracy - najpopularniejszą metodą jest zastępowanie jej liczbą zatrudnionych, lecz w przypadku badań produkcji potencjalnej, należy wyliczyć efektywne zasoby pracy. Kapitał fizyczny może być aproksymowany przez różne zmienne (wartość brutto środków trwałych lub zakumulowane inwestycje, gdzie należy określić wartość kapitału początkowego oraz stopę deprecjacji), również elastyczność produkcji $\alpha$ może być wyliczana według różnych formuł i podejść. Zazwyczaj badacze nie przedstawiają szczegółowych wyjaśnień co do zastosowanej metody wyliczeń, pomimo, że sposób wyznaczenia zmiennych i parametrów we wzorze 1.3.2.1 lub 1.3.2.2 wpływa na wielkość i dynamikę $T F P$ oraz, co za tym idzie, wnioski co do konwergencji. Poniżej omówiono bardziej szczegółowo kwestie związane z wyliczaniem, jak również endogenizacją TFP.

regresji wzrostu produktu per capita, gdzie początkowy poziom produktu interpretowany jest jako dystans technologiczny między daną gospodarką i technologicznym liderem (por. Nowak [2006]). ${ }^{40}$ Można również używać PKB, jak i wartości produkcji sprzedanej. Użycie wartości dodanej brutto wynika z dostępności odpowiednich danych dla wszystkich sektorów gospodarczych. 


\subsubsection{Ustalenie wartości zmiennych i parametrów w formule $T F P$}

Przy ustalaniu wartości elastyczności $\alpha$ we wzorze (1.3.2.1) możliwe są następujące podejścia:

1) przyjęcie pewnej, z góry określonej wartości; w literaturze przedmiotu, np. u Welfe [2001, 2009], Gradzewicza i Kolasy [2004], Florczaka [2001], jest to wartość $\alpha=0.5$,

2) wykorzystanie wyników klasycznej teorii produkcji (jak np. w pracy Malaga, Kliber [2007]),

3) oszacowanie parametru $\alpha$ metodami ekonometrycznymi,

z których szerszego omówienia wymaga drugie i trzecie.

Ad 2) Wykorzystanie wyników klasycznej teorii produkcji polega na aproksymacji wartości $\alpha$ przez udział nadwyżki operacyjnej brutto w produkcji, co przy założeniu, że nadwyżkę tworzy wielkość produkcji skorygowana o koszty pracy, może być tożsame z przyjęciem, że elastyczność produkcji względem liczby pracujących (1- $\alpha$ ) jest równa udziałowi wynagrodzenia $z$ tytułu pracy (koszty pracy) w produkcji danego regionu ${ }^{41}$.

Ad 3) Szacowanie parametru $\alpha$ metodami ekonometrycznymi, na przykład przy wykorzystaniu funkcji produkcji Cobba-Douglasa (por. podpunkt 1.2.2), przekształconej do postaci równania wydajności pracy ${ }^{42}$ (gdzie nieznane wartości TFP są zastępowane przez zmienną czasową) $)^{43}$ :

$$
\ln \left(\frac{Y_{t}}{L_{t}}\right)=g t+\alpha \ln \left(\frac{K_{t}}{L_{t}}\right)
$$

lub w postaci temp wzrostu:

$$
\ln \left(\frac{Y_{t}}{L_{t}}\right)-\ln \left(\frac{Y_{t-1}}{L_{t-1}}\right)=\alpha\left(\ln \left(\frac{K_{t}}{L_{t}}\right)-\ln \left(\frac{K_{t-1}}{L_{t-1}}\right)\right)
$$

\footnotetext{
${ }^{41}$ Niektórzy autorzy (Welfe [2006, s.187]) twierdzą jednakże, że sposób ten nasuwa wątpliwości wobec niejednolitych definicji kosztów pracy. Z badań przeprowadzonych w niniejszej książce wynika jednakże, że wątpliwość ta ma zastosowanie głównie do kosztów pracy w poszczególnych sektorach gospodarki (por. tabela 3.4.4.1), zaś dla całej gospodarki doprowadza do dość wiarygodnych szacunków elastyczności (por. tabela 3.1.2.1).

Pozostaje kwestia jakiego miernika produkcji należy użyć. Suma nadwyżki operacyjnej brutto i kosztów pracy jest najbliższa wartości dodanej brutto, a nie PKB, w którego skład wchodzi również wartość podatków, ani tym bardziej produkcji sprzedanej.

42 Przekształcenie funkcji produkcji Cobb-Douglasa do postaci funkcji wydajności pracy pozwala uniknąć nakładania restrykcji na oryginalne równanie (1.2.2.1), co do sumowania się elastyczności do 1 .

${ }^{43} \mathrm{~W}$ równaniach pominięto składnik losowy i wyraz wolny.
} 
Równanie (1.3.2.1.2) pozwala na uniknięcie efektów ewentualnej niestacjonarności zmiennych, lecz jednocześnie nie pozwala na oszacowanie efektów postępu technologicznego (parametru $g$ ). Sposobem, który rozwiązuje oba te problemy i dodatkowo porządkuje kwestię egzogeniczności zmiennych jest zastosowanie modelu typu Vector Error Correction Model - VECM (użyty w tym samym celu przez Gradzewicza i Kolasę [2004, s. 15-16]). Model VECM, eliminuje negatywne skutki niestacjonarności zmiennych oraz pozwala na oszacowanie parametru $\alpha$ (odczytywanego z relacji długookresowej), jak i na oszacowanie stopy postępu technologicznego $g$ (dzięki zastosowaniu postaci VECM $\mathrm{z}$ tzw. ograniczonym trendem ${ }^{44}$ ).

Powracając do wzorów (1.3.2.1.1) - (1.3.2.1.2) umożliwiających oszacowanie elastyczności produkcji względem kapitału $\alpha$ należy w nich również zdefiniować zmienną, która będzie reprezentowała kapitał fizyczny (majątek produkcyjny przedsiębiorstw) ${ }^{45}$. Zmienna ta może być aproksymowana za pomocą wartości brutto środków trwałych, lub szeregu wyliczanego wg formuły akumulacji (zmiany) kapitału (por. wzór 1.2.2):

$$
K_{t}=K_{t-1}+I_{t}-\delta K_{t-1}=(1-\delta) K_{t-1}+I_{t}
$$

gdzie: $\delta$-współczynnik deprecjacji kapitału, $I_{t}$ - wartość inwestycji, $K_{t}-$ wartość kapitału.

Zaletą pierwszego podejścia ( $K$ - jako wartość brutto środków trwałych) jest stosunkowo duża aktualność danych statystycznych (na początku roku 2012, kiedy dopiero od niedawna były znane dane dotyczące regionalnego PKB za 2009 r., były już dostępne wojewódzkie wartości brutto środków trwałych za rok 2010). Natomiast mankamentem tych danych jest fakt, że wyrażają one jedynie księgowy zapis stanu tych środków według cen ich nabycia $\mathrm{z}$ uwzględnieniem procesów likwidacji majątku (co, jak wynika z innych analiz autorki, może być przyczyną niezbyt realnego odzwierciedlenia majątku rolnictwa w niektórych latach).

W przypadku drugiego podejścia w wyznaczaniu kapitału $K_{t}$ (wzór 1.3.2.1.3), przed przystąpieniem do obliczeń, należy ustalić parametry: $K_{0}$ (kapitał początkowy) oraz stopę deprecjacji $\delta$, co może nastręczać pewnych trudności. W zależności od przyjętego sposobu wyliczania kapitału początkowego $K_{0}$ (któ-

\footnotetext{
${ }^{44} \mathrm{~W}$ modelach VECM wyraźnie odróżnia się pozycję wyrazu wolnego i trendu: włączone w relację kointegracyjną (postać ograniczona) lub poza nią (postać nieograniczona) - zob. podrozdział 2.4.3. Ma to wpływ na procesy generujące zmienne i, w konsekwencji, na liczbę wektorów kointegracyjnych i ich postać.

${ }^{45}$ Kapitał ludzki jest uwzględniany w czynnikach wyjaśniających $T F P$ - por. p. 1.3.2.3.
} 
ry przyjmuje się na poziomie wielokrotności - ustalanej przy użyciu stopy deprecjacji i/lub stopy wzrostu inwestycji - inwestycji, rzadziej produkcji) jego początkowo wyższa (niższa) wartość obniża (podwyższa) dynamikę całego szeregu $K_{t}$. Ustalenie stopy deprecjacji $\delta$ we wzorze (1.3.2.1.3) wymaga podjęcia decyzji, czy ma ona być stała, czy zróżnicowana w poszczególnych regionach, sektorach oraz czasie. Przy ustaleniu stopy deprecjacji można przyjąc następujące sposoby postępowania:

1) przyjąć pewną arbitralną (na przykład na podstawie studiów literaturowych) wartość, często jest to $\delta=0,05$ (rzadziej 0,06$)^{46}$,

2) oszacować stopę deprecjacji przy wykorzystaniu formuły (1.2.2) oraz danych o wartości inwestycji $(I)$ i środkach trwałych $(K)$,

3) oszacować stopę deprecjacji wykorzystując wiedzę o strukturze majątku produkcyjnego przedsiębiorstw i stopie amortyzacji poszczególnych jego składników. W tym celu można wykorzystać ustawy podatkowe (o podatku dochodowym, w których określa się czas amortyzacji poszczególnych składników majątku ${ }^{47}$ ), a w celu wyliczenia wspólnej dla całego majątku produkcyjnego stopy - strukturę majątku trwałego (raportowaną w opracowaniach „Środki trwate w gospodarce narodowej”).

\subsubsection{Potencjalne i efektywne TFP}

W funkcjach produkcji Cobba-Douglasa przyjmuje się zazwyczaj, że dostępne czynniki produkcji zostają w pełni wykorzystane, co oznacza, że popyt efektywny na produkcję jest równy produkcji potencjalnej. Tymczasem założenie to jest bardzo rzadko spełnione $-\mathrm{z}$ reguły potencjalna produkcja nie jest $\mathrm{w}$ pełni wykorzystana ${ }^{48}$.W literaturze przedmiotu nie ma jednomyślności co do definicji i pomiaru produkcji potencjalnej. Wśród dostępnych procedur ${ }^{49}$ można zastosować postępowanie wykorzystane w artykule Florczaka [2011, s. 11], zwane metodą Whartona (metoda funkcji produkcji). W metodzie tej najpierw wylicza się kapitałochłonność potencjalną, następnie produkcję potencjalną, efektywne zatrudnienie, a na ich podstawie - efektywne TFP:

\footnotetext{
${ }^{46}$ Stopy te są inne w zależności od rodzaju inwestycji. Na przykład dla skumulowanych nakładów na B\&R przyjmuje się stopę deprecjacji wiedzy technicznej rzędu $\delta=0,05-0,15$ (por. Welfe [2004, s.28]).

${ }^{47}$ Zgodnie z zapisami ustawowymi (por. p. 3.1.3) czas amortyzacji poszczególnych rodzajów środków trwałych może znacznie się od siebie różnić, co jest argumentem za dokonywaniem, jeśli jest to możliwe, podziału poszczególnych składników majątku i ustalaniu dla nich osobnych stóp amortyzacji.

${ }^{48}$ Zob. Welfe [2006, s. 185].

${ }^{49}$ Zob. Florczak [2011, s. 9], Gradzewicz, Kolasa [2004, s. 14].
} 


$$
T F P E_{t}=\frac{Y_{t}}{K E_{t}^{\alpha} L E_{t}^{(1-\alpha)}}
$$

gdzie $T F P E_{t}$ - efektywny poziom łącznej produktywności czynników produkcji, $Y_{\leftarrow}-$ wartość produkcji, $K E_{t}$ - efektywny wolumen (wartość) kapitału rzeczowego $\left(K E_{t}=W W M_{t} * K_{t}\right.$, gdzie $W W M-$ współczynnik wykorzystania mocy produkcyjnych wyznaczony metodą Whartona, $K$ - księgowa wartość kapitału rzeczowego), $L E_{t}$ - efektywne nakłady pracy mierzone (najczęściej) liczbą przepracowanych godzin.

Na użytek tej pracy dokonano symulacji stopy wzrostu TFP przy użyciu wzoru (1.3.2.1) oraz TFPE przy użyciu wzoru (1.3.2.2.1), co pokazało pewne różnice w tempach wzrostu obu zmiennych (tempa wzrostu TFPE były, dla niektórych województw, nieco wyższe niż $T F P^{50}$ ), choć ostatecznie przyjęto definicję $T F P$ wg $(1.3 .2 .1)^{51}$.

\subsubsection{Endogenizacja TFP}

Jak pisano na początku podrozdziału 1.3.2 niezgodność pomiędzy zwolennikami neoklasycznego i endogenicznego modelu wzrostu dotyczy głównie źródeł postępu technologicznego (TFP). „Technicznie” rzecz ujmując spór toczy się o endogenizację TFP.

Popularnością w próbach endogenizacji TFP cieszą się nakłady na $\mathrm{B} \& \mathrm{R}$ (powiększających kapitał wiedzy ucieleśniony w środkach trwałych) ${ }^{52}$, nakłady na edukację (stanowiących inwestycje w kapitał ludzki), oraz czasami wydatki na oprogramowanie (software) - określane przez OECD wspólnym mianem inwestycji w wiedzę ${ }^{53}$.

Generalnie, zmiany postępu technologicznego można rozpatrywać bądź łącznie, bądź właśnie zdekomponowane na czynniki: efekty postępu technologicznego

\footnotetext{
${ }^{50}$ Dodatkowo, oszacowane wartości poziomów TFPE były niższe niż TFP (co oznaczało, że reszty $\mathrm{z}$ równania produkcji Solowa dla produkcji potencjalnej są mniejsze, a samo równanie lepiej dopasowanie do danych empirycznych).

${ }^{51}$ Co było podyktowane głównie problemami z niektórymi danymi do wzoru (1.3.2.2.1) w dezagregacji jednocześnie wojewódzkiej i sektorowej.

${ }^{52}$ Choć w pracy Zienkowskiego [2003] sformułowano wątpliwości co do zasadności traktowania wydatków na badania podstawowe jako nakładów na wiedzę, ze względu na ich luźny związek $\mathrm{z}$ nagromadzeniem wiedzy.

${ }^{53}$ Ideę endogenizacji postępu technicznego wysunął w 1966 r. K. Shell. Z jego modelu wynikało, że ponieważ proces akumulacji wiedzy naukowo-technicznej ma charakter endogeniczny, to gospodarka może skutecznie podnieść stopy wzrostu gospodarczego poprzez podnoszenie stóp inwestycji w zasób kapitału i wiedzę naukowo-techniczną (por. Welfe [2001, s.17]). W pracy Dańskiej-Borsiak [2011, s. 183] można znaleźć przykłady pionierskich prac z tej dziedziny.
} 
ucieleśnionego w środkach trwałych $\left(A^{K}\right)$, w pracujących $\left(A^{N}\right)$ oraz efekty ogólnego postępu wiedzy $\left(A^{W}\right)^{54}$. Ostatni komponent - efekty ogólnego postępu wiedzy są czasami traktowane jako ciągłe i stąd przyjmuje się, że są funkcją czasu. Postęp technologiczny, ucieleśniony w środkach trwałych wiąże się z oddziaływaniem wydatków poniesionych na $B \& R$, co można przestawić, jak w pracy Świeczewskiej [2012], jako funkcję skumulowanych wartości nakładów na badania i rozwój, poniesionych zarówno w kraju, jak i zagranicą:

$$
\ln \left(A^{K}\right)=\lambda_{1} \ln (B R S)+\lambda_{2} \ln (B R S F)
$$

gdzie: $B R S$ - skumulowane nakłady na $\mathrm{B} \& \mathrm{R}$ w kraju, $B R S F$ - skumulowane nakłady na $B \& R$ zagranicą.

Efekty postępu technicznego ucieleśnionego w pracujących tj. kapitale ludzkim, odwzorowują różnego rodzaju mierniki akumulacji kapitału ludzkiego (którego sposoby pomiaru mogłyby stanowić przedmiot osobnej rozprawy). W niniejszej pracy dwojako zdefiniowano kapitał ludzki: jako udział pracujących z wyższym wykształceniem oraz poprzez indeks edukacyjny (podobnie jak w pracy Durlaufa, Johnsona [1995], s. 368) ${ }^{55}$.

\subsubsection{Konwergencja sektorowa}

Struktura sektorowa gospodarki jest jednym z czynników decydującym o konwergencji. Boldrin i Canova [2001, s. 211] stwierdzają, że szczególnie udział rolnictwa jest jednym z głównych czynników które mają wpływ na rozwarstwienie regionalnych dochodów - dywergencję. W artykule Gorzelaka [2008, s. 76] można przeczytać, że należy spodziewać się procesów koncentracyjnych w przypadku wysokich segmentów gospodarki, w których przewagę uzyskuje się dzięki innowacjom oraz procesów konwergencyjnych w przypadku segmentu niskiego (w którym dąży się do uzyskania przewagi komparatywnej wytwarzaniu po niskich kosztach).

Z badań Kolko [1999] wynika, że usługi wykazują tendencje koncentracyjne w przeciwieństwie do pozostałych sektorów, a w badaniu Doyle i O'Leary'ego (prowadzonego dla 11 krajów UE i lat 1970-1990) potwierdzono dywergencję

\footnotetext{
${ }^{54}$ Por. Welfe [2004, s.26].

55 Sposób wyliczenia indeksu edukacyjnego dla województw Polski podaje praca Kusideł [2013a], zaś liczbę pracujących z wykształceniem wyższym (w przekroju województw i sektorów gospodarki) otrzymano dzięki indywidualnym ankietom z BAEL (Badanie Aktywności Ekonomicznej Ludności).
} 
w sektorze rolniczym i przemysłowym i konwergencję w usługach ${ }^{56}$. Również w badaniu Bernarda i Jonesa [1996] stwierdzono brak konwergencji w produkcji przemysłowej i silną konwergencję w sektorze usług ${ }^{57}$. Podobny wniosek wysnuli Le Gallo i Dall'erba [2007, s. 506] badając regiony NUTS 2 w UE (pokazują oni brak konwergencji dla sektora przemysłowego, w przeciwieństwie do sektora usług). Generalnie, we wszystkich cytowanych badaniach, można odnaleźć wspólny wniosek, że większy stopień konwergencji występuje na poziomie zagregowanym niż sektorowym ${ }^{58}$.

W badaniach ekonomicznych określających poziom rozwoju lub innowacyjności gospodarki stosuje się różne mierniki. Jednym z podejść jest tzw. teoria trzech sektorów, która stwierdza, że kraje lub regiony znajdujące się na wyższych etapach rozwoju, charakteryzują się relatywnie wysokim udziałem sektora usługowego (sektor III), niskim udziałem sektora rolniczego (sektor I) i umiarkowanym udziałem sektora przemysłowego (sektor II). O ile wątki związane z rolą poszczególnych sektorów gospodarczych można odnaleźć nawet w odległej historii ekonomii, to główna teoria trzech sektorów powstała w latach trzydziestych XX wieku. Za twórców badań nad prawidłowościami rozwoju trzech głównych działów gospodarki uznaje się ekonomistów: A. Fishera, C. Clarka i J. Fourastié'a ${ }^{59}$. Według tych autorów rozwój gospodarczy

\footnotetext{
${ }^{56}$ Autorzy znaleźli wytłumaczenie tego faktu w przemianach strukturalnych: zmiany strukturalne w udziale sektorowego zatrudnienia stanowiły 50-66\% całej stopy wzrostu zbieżności (konwergencji) zagregowanej produktywności. Kraje o niskiej produktywności zagregowanej najbardziej skorzystały na przemianach strukturalnych.

${ }^{57} \mathrm{Na}$ tej podstawie stwierdzono, że to sektor usług, a nie przemysł, doprowadził do ogólnej konwergencji. W artykule Wei-Kang Wonga [2006] pokazano, że nie tylko konwergencja w usługach, ale również w rolnictwie powoduje, że biedniejsze kraje OECD rozwijają się szybciej niż bogatsze.

${ }^{58}$ Z badania Dollara i Wolffa [1988] wynika, że dotyczy to każdego poziomu agregacji (nie tylko narodowego), bowiem odkryto, że konwergencja produktywności pracy jest wyższa dla całego sektora przemysłowego niż dla jego poszczególnych działów.

${ }^{59}$ Wspomniani badacze nieco inaczej definiowali poszczególne sektory. Podstawą podziału stworzonego przez Allana Fishera był wskaźnik dochodowej elastyczności popytu, wg którego do sektora I należały gałęzie wytwarzające dobra pierwszej potrzeby o wskaźniku elastyczności poniżej 0,5 , do sektora II należały gałęzie produkujące dobra o elastyczności między 0,5 a 1 , zaś do sektora III zaliczył on gałęzie produkujące dobra luksusowe, o elastyczności dochodowej powyżej 1 (taki podział zawężał się wszak jedynie do dóbr konsumpcyjnych oraz był nieodporny na zmiany zakresów trzech sektorów, które dokonywały się pod wpływem zmian dochodów). Colin Clark zaproponował nazwy dla sektorów I, II, III: rolniczy, przemysłowy i usługowy, a za podstawę klasyfikacji przyjął prawo malejących (w sektorze rolniczym) lub rosnących (w sektorze przemysłowym) przychodów. Podkreślał, że produkcja rolnicza polega na pozyskiwaniu zasobów przyrody, a przemysłowa na ich przetwarzaniu. Zauważył również, że towary rolnicze i przemysłowe podlegają obrotowi handlowemu, w przeciwieństwie do usług. Ostatecznie, podstawą podziału gospodarki według Clarka stało się kryterium wymienialności dóbr: sektory rolniczy i przemysłowy to te, które wytwarzają dobra dające się transportować i co za tym idzie podlegające
} 
narodów wynika głównie ze zmieniającej się roli poszczególnych sektorów w procesie kształtowania gospodarek - por. rys. 1.3.3.1.

Rys. 1.3.3.1. Ewolucja przekształceń trójsektorowej struktury zatrudnienia

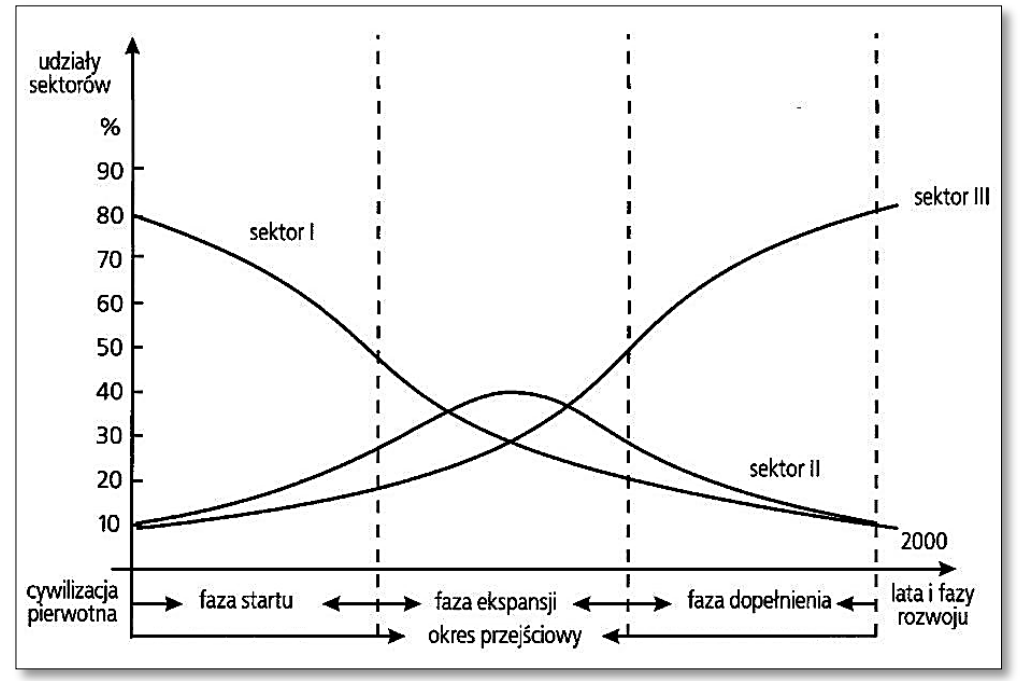

Źródło: E. Kwiatkowski [1980, s. 98]

Zgodnie z trójsektorową teorią zatrudnienia (por. Kwiatkowski [1980, s. 100]), należy wymienić następujące stadia rozwoju gospodarczego cywilizacji:

1) stadium cywilizacji pierwotnej, które trwało do około 1800 r., kiedy to gospodarki rozwijały się stosunkowo wolno i kiedy dominował udział zatrudnienia w sektorze I; rewolucja przemysłowa, szybki wzrost produkcji i poprawienie się poziomu życia umożliwiły przejście do wyższego stadium rozwojowego,

2) stadium okresu przejściowego ${ }^{60}$, na który składają się: faza startu (kiedy to następuje dynamiczny wzrost zatrudnienia w sektorze II, czemu towarzyszy powolny wzrost jakości życia społeczeństwa), faza ekspansji (maksymalne zatrudnienie w przemyśle, czemu towarzyszy wzrost jakości życia i, dzięki dynamice postępu technologicznego, wydajności pracy), faza do-

obrotowi handlowemu, natomiast sektor usługowy charakteryzuje się produkcją dóbr niematerialnych, których transport nie jest możliwy (podobne kryterium stanowi podstawę podziału sektorowego w modelu HERMIN). Jean Fourastié za podstawę podziału gospodarki przyjął dynamikę postępu technicznego, zgodnie z którą sektor I, II, III charakteryzuje się odpowiednio umiarkowaną, silną i słabą dynamiką postępu technicznego, por. Kwiatkowski [1980]. Współcześnie podstawą podziału na sektory gospodarcze jest Polska Klasyfikacji Działalności (PKD), o której szerzej traktuje rozdział 3.1.4.

${ }^{60}$ Które rozpoczęło się wg Fishera na przełomie XVIII i XIX w. 
pełnienia (kiedy to w sektorze II następuje spadek zatrudnienia, które dynamicznie rośnie w sektorze III),

3) stadium cywilizacji tercjarnej, kiedy to sektor III ma dominujące znacznie; stadium to może charakteryzować się nawet $80 \%$ udziałem usług w ogólnym zatrudnieniu i może wystąpić w najbardziej rozwiniętych krajach około 2020 roku (udział usług w Luxemburgu osiągnął już ten próg).

Historia krajów europejskich dowodzi słuszności teorii trzech sektorów w kwestii jej przełożenia na poziom rozwoju gospodarczego (i, pośrednio, na poziom zaawansowania technicznego). Otóż kraje, w których można zaobserwować relacje pomiędzy sektorami takie, jak w trzeciej części rysunku 1.3.3.1, są krajami o wysokim poziomie rozwoju gospodarczego. Luksemburg, Belgia, Holandia, Francja, Niemcy, Dania, Wielka Brytania, Szwecja to kraje o najwyższym, ponad $70 \%$, udziale zatrudnienia w usługach oraz udziale pracujących w rolnictwie poniżej 5\% (w Luksemburgu udział pracujących w usługach wynosi nawet $80 \%$, przy zaledwie $2 \%$ zatrudnieniu w rolnictwie).

\subsubsection{Konwergencja wewnętrzna i hipoteza Williamsona}

Jednym z kryteriów podziału konwergencji jest jej podział wg zakresu terytorialnego badań - obszaru statystycznego. Badania konwergencji można prowadzić dla krajów i dla mniejszych obszarów statystycznych, które dotyczą najczęściej regionów NUTS $2^{61}$. Można tutaj wyróżnić badania, które traktują regiony NUTS 2 pochodzące $\mathrm{z}$ wielu krajów razem (np. konwergencja wśród NUTS 2 dla krajów UE, lub inaczej zdefiniowanej grupy krajów - np. Europy Wschodniej, Krajów Wyszechradzkich itp.), jak i takie, które dotyczą jedynie terytorium danego kraju. W celu rozróżnienia badań prowadzonych dla grupy państw od badań dla regionów jednego państwa rozróżnia się je pojęciowo: na konwergencję międzykrajowa i wewnątrzkrajowa ${ }^{62}$ lub konwergencję zewnętrzna i wewnętrzna (por. np. Łaźniewska i in. [2011, s. 5], gdzie tę ostatnią nazywa się również regionalną i międzyregionalną). Konwergencja wewnętrzna (wewnątrzkrajowa) może dotyczyć jednostek statystycznych NUTS 2, jak i NUTS 3. Jak piszą jednakże Boldrinii i Cannova [2001, s. 212] o rozmiarach terytoriów podlegających badaniom konwergencji: „,należy rozważać wystarczajaco duży obszar co do wielkości populacji $i$ wystarczajaco heterogeniczny co do wyposażenia w czynniki produkcji”. Wg tych autorów większość regio-

\footnotetext{
${ }^{61}$ Od 1988 r. Wspólnota Europejska posługuje się w operacjach polityki regionalnej jednolitą strukturą jednostek terytorialnych - systemem NUTS. System ten dzieli państwo (NUTS 0) na 5 poziomów podziału regionalnego: NUTS 1 (makroregiony, których w Polsce jest 6), NUTS 2 (województwa), NUTS 3 (podregiony), NUTS 4 (powiaty), NUTS 5 (gminy).

${ }^{62}$ Jest to wierne tłumaczenie pojęć funkcjonujących w anglosaskiej literaturze: between-country i within-country convergence.
} 
nów NUTS 3 nie spełnia tych warunków, co nie pozwala traktować ich jako niezależnych obszarów ekonomicznych. Z drugiej strony obszary NUTS 2 odzwierciedlają czasami kondycję ekonomiczną swojej aglomeracji w przypadku badań polskich dotyczy to województwa mazowieckiego, dla którego wysokie wskaźniki ekonomiczne charakteryzują głównie aglomerację warszawską, a nie całe województwo.

Wiele krajów-beneficjentów polityki spójności notuje podobną do Polski rozbieżność: doganianie średnich europejskich przez gospodarkę całego kraju (konwergencja zewnętrzna) przy jednoczesnym rosnącym zróżnicowaniu gospodarczym wewnątrz kraju (dywergencja wewnętrzna). Jedną z teorii thumaczących brak konwergencji wewnętrznej jest hipoteza Williamsona [1965], zgodnie z którą ze zjawiskiem konwergencji spotkać się można dopiero na wyższych etapach rozwoju poszczególnych gospodarek. Dla krajów opóźnionych rozwojowo wzrost dochodów powoduje początkowo wzrost nierówności pomiędzy poszczególnymi regionami. Dzieje się tak ze względu na początkowy szybszy wzrost ośrodków dobrze prosperujących ${ }^{63}$. W miarę wzrostu dochodów, wzrost nierówności ma tendencję malejącą (por. np. GawlikowskaHueckel, Zielińska-Głębocka [2004, s. 223], Geodecki [2006, s.76]). Graficzne odzwierciedlenie tego procesu nosi nazwę hipotezy odwróconego $U$ - jak na rysunku 1.3.4.1 $1^{64}$.

\footnotetext{
${ }^{63}$ Zgodnie z hipotezą dywergencji (polaryzacji) im bogatszy region (im wyższe techniczne uzbrojenie pracy), tym szybciej może się rozwijać (tym większy przychód z inwestycji). Dodatkowo, regiony takie przyciągają kapitał ludzki, co pozwala im szybciej i efektywniej wdrażać nowe technologie.

${ }^{64}$ Krzywa Wiliamsona do złudzenia przypomina zbudowaną i opisaną 10 lat wcześniej krzywą Kuznetza [1955], który starał się odpowiedzieć na pytanie, czy nierówności wynikające z dystrybucji dochodu rosną czy maleją w trakcie wzrostu gospodarczego. Kuznetz odpowiada na to pytanie formułując podobną, do Williamsona, zależność, wg której wzrost w początkowej fazie prowadzi do zwiększenia, a później do spadku nierówności dochodowych czego powodem są m.in. zmiany struktury sektorowej gospodarki, które dokonują się wraz ze wzrostem gospodarczym (o zastosowaniach krzywej Kuznetza w podobnym, do hipotezy Williamsona, kontekście pisze P. Kumor [2009]).
} 
Rys. 1.3.4.1. Krzywa Williamsona - odwróconego U

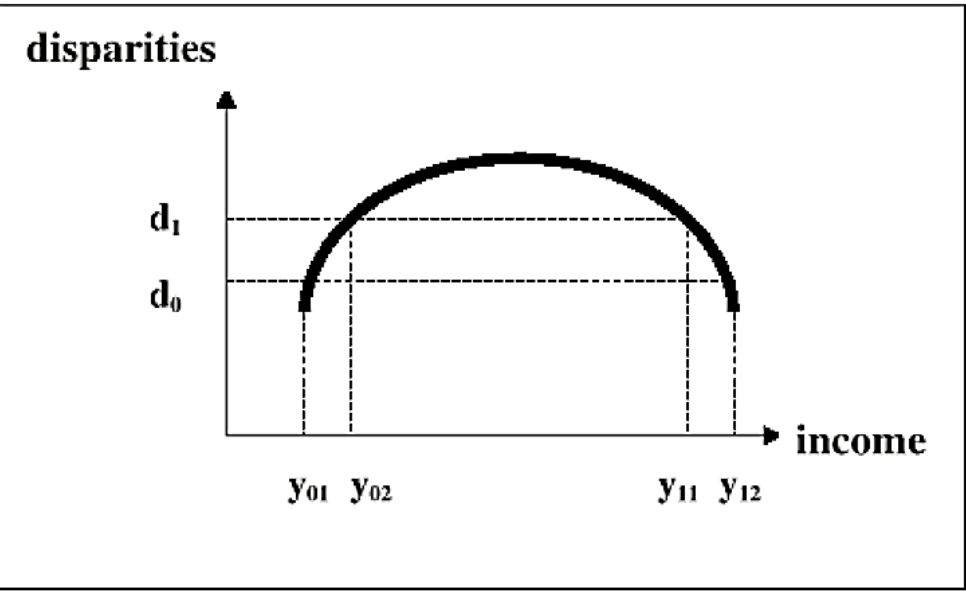

Źródło: Davies, Hallet [2002, s. 5]

Wg Williamsona istnieje optymalny punkt dochodów i nierówności regionalnych, w którym realizowane są preferencje społeczne. Osiągnięcie tego punktu jest łatwiejsze w gospodarkach wolnorynkowych (o dużym stopniu decentralizacji) i regionalnych (bowiem centralne polityki, przynajmniej na początku silnego wzrostu, są nastawione na rozwój ośrodków najsilniejszych - co początkowo powoduje wzrost nierówności regionalnych). Dopiero w dłuższym okresie, dzięki dyfuzji i polaryzacji, rozwój ośrodków centralnych, pociąga za sobą rozwój całego regionu, co prowadzi ostatecznie do zmniejszania się dysproporcji.

Model empiryczny, pozwalający weryfikować hipotezę Williamsona, polega na oszacowaniu parametrów wielomianu drugiego stopnia (paraboli) postaci:

$$
y_{t}=\alpha_{0}+\alpha_{1} x_{t}+\alpha_{2} x_{t}^{2}
$$

gdzie: $y_{t}$ - zmienna reprezentująca zróżnicowanie badanego zjawiska w czasie (np. współczynnik zmienności PKB pc. w kolejnych okresach $t$ ), $x_{t}$ - wskaźnik wzrostu gospodarczego (PKB pc. w kolejnych okresach $t$ ).

Jeżeli estymator parametru $\alpha_{1}$ jest dodatni, a estymator parametru $\alpha_{2}$ ujemny, można potwierdzić, że wzrost gospodarczy jest powiązany z jego regionalnym zróżnicowaniem poprzez krzywą w kształcie odwróconego U (paraboliczną). 


\subsection{Podsumowanie}

W literaturze ekonomicznej brak jest jednoznacznego rozstrzygnięcia co do istnienia i źródeł konwergencji gospodarczej. Podobnie jest w tej pracy - opisane koncepcje ekonomiczne i wynikające $\mathrm{z}$ nich argumenty za i przeciw konwergencji dają negatywną odpowiedź na pytanie o jednoznaczną definicję, czy istnienie tego zjawiska, choć są teoretycznym uzasadnieniem badań konwergencji w rozdziałach empirycznych.

Również intensywnie prowadzone badania empiryczne nie dostarczają jednoznacznych wniosków co do istnienia konwergencji gospodarczej, co więcej, są one nawet czasami ze sobą sprzeczne. Wynika to między innymi z mnogości koncepcji i metod pomiaru tego zjawiska - w literaturze przedmiotu funkcjonują określenia: stochastyczna, deterministyczna, beta-, sigma-, gammakonwergencja; konwergencja do stanów równowagi; konwergencja gospodarcza (dochodowa, technologiczna), społeczna, przestrzenna (a także ostatnio zrównoważonego rozwoju); konwergencja sektorowa czy klubowa. Określenia te dotyczą różnych kryteriów podziału konwergencji i są jedną z przyczyn różnych (także sprzecznych) wyników tylko na pozór tego samego zjawiska. Z rozważań z niniejszego rozdziału wynika, że w celu uporządkowania tych pojęć (i częściowej realizacji pierwszego głównego celu pracy) należy wyróżnić (przynajmniej) następujące kryteria podziału zjawiska konwergencji.

1. Obszar tematyczny badań konwergencji i związany z nim rodzaj użytego indykatora (wskaźnika, miernika, zmiennej, cechy). Jeżeli badaną cechą jest PKB per capita lub inne indykatory aktywności gospodarczej (o których szerzej traktują podrozdziały 1.3.1-1.3.3), to mówimy o konwergencji gospodarczej (ekonomicznej) - najczęściej weryfikowanej koncepcji w literaturze przedmiotu ze względu na jej duże powiązania z teoriami wzrostu gospodarczego i wynikającymi z nich implikacjami (np. dla prowadzonej polityki gospodarczej). Badaną zmienną może być jednakże dowolna cecha charakteryzująca wiele innych, niż jedynie gospodarka, płaszczyzn życia. W szczególności realizowana w ramach polityki regionalnej UE - polityka spójności, dąży do podwyższenia poziomu, nie tylko spójności gospodarczej, ale również społecznej i terytorialnej (przestrzennej), co jest często przyczynkiem do badań konwergencji społecznej, czy terytorialnej. Obszar badań w niniejszej książce odnosi się do szeroko pojętej konwergencji gospodarczej ${ }^{65}$. „Szerokość” pojęcia dotyczy zakresu badanych indykatorów gospodarczych, który zawiera nie tylko najpopularniejszy wskaźnik PKB

\footnotetext{
${ }^{65}$ Wątek konwergencji społecznej i przestrzennej był rozważany w innych pracach autorki (por. Kusideł, Górniak [2012], Kusideł [2010b], Kusideł [2013a], Kusideł [2013b]).
} 
per capita, lecz również wydajność pracy oraz łączną produktywność czynników produkcji ${ }^{66}$.

Należy jednocześnie podkreślić, że w ramach konwergencji gospodarczej funkcjonują dwa zasadnicze i całkowicie odmienne sposoby jej rozumienia: konwergencja nominalna (dotycząca spełnienia przez poszczególnych kraje tzw. kryteriów z Maastrich, o których pisano na początku tego rozdziału) oraz konwergencja realna (dotycząca przemian gospodarczych doprowadzających do większej zbieżności badanych gospodarek), której dotyczy niniejsza praca.

2. Zasięg terytorialny badań i rodzaj jednostek statystycznych NUTS. Badania konwergencji prowadzone są dla krajów - jednostek statystycznych NUTS 0 (between-country convergence), jak i dla regionów - jednostek statystycznych NUTS 2 (rzadziej NUTS 3) - wówczas mówimy o konwergencji regionalnej (międzyregionalnej). Badania regionalne można prowadzić dla regionów wielu krajów jednocześnie, jak i regionów wewnątrz jednego kraju. W tym drugim przypadku mówimy o konwergencji wewnętrznej (withincountry convergence), która jest również rodzajem konwergencji regionalnej (międzyregionalnej), lecz w ramach jednego kraju - takie badania są prowadzone w niniejszej książce.

3. Metodologia pomiaru konwergencji, która dzieli to zjawisko na konwergencję: beta (absolutną i warunkową), sigma, gamma, stochastyczną i do stanów równowagi ${ }^{67}$. O rodzajach tych traktuje szerzej rozdział 2.

4. Homogeniczność badanej grupy. Jednym z głównych założeń zaistnienia procesu konwergencji jest podobieństwo (przynajmniej co do pewnych początkowych warunków) badanych gospodarek (dlatego łatwiej jest osiągnąć konwergencję gospodarczą w skali Europy niż w skali świata - por. rozdział 4). Na początku drugiej połowy lat 90 . XX w. (por. Durlauf, Johnson [1995], Galor [1996]) pojawiła się koncepcja klubowej konwergencji (club convergence), zgodnie $\mathrm{z}$ którą tylko pewne grupy (kluby, klastry) regionów osiągają konwergencję, podczas gdy pomiędzy klubami, pomimo, że charakteryzują ten sam obszar statystyczny (np. to samo państwo), mogą

\footnotetext{
${ }^{66}$ Różnice terminologiczne (konwergencja dochodowa, wydajnościowa, TFP) mogłyby być właściwie pominięte, bowiem wszystkie tego rodzaju badania można nazwać wspólnym mianem badań konwergencji gospodarczej, ze względu na fakt, że badane zmienne (PKB per capita, wydajność pracy, TFP) charakteryzują gospodarki regionów - w odróżnieniu od konwergencji społecznej i przestrzennej. Niemniej dla zapewnienia większej przejrzystości pracy wprowadzono rozróżnienie pomiędzy konwergencją dochodową (poprzez badania regionalnych PKB per capita), wydajnościową (wydajność pracy) i technologiczną (łączna produktywność czynników produkcji).

${ }^{67}$ Konwergencja do stanów równowagi nie stanowi właściwie osobnego rodzaju, bowiem główną ideą zjawiska konwergencji jest dążenie badanych obszarów do stanu równowagi. Wyróżniono ją ze względu na metodę wyznaczania stanu równowagi (por. podrozdział 1.2.1).
} 
zachodzić procesy dywergencji. W literaturze przedmiotu wspomina się $\mathrm{w}$ tym kontekście o konwergencji globalnej i lokalnej (klubowej).

5. Podział badanej gospodarki na sektory gospodarcze i badanie konwergencji nie tylko na poziomie zagregowanym, lecz również w poszczególnych sektorach - jeśli takiego podziału dokonano (jak w podrozdziale 3.4), to można mówić o konwergencji sektorowej.

Powyższy podział pozwala na częściową realizację pierwszego głównego celu pracy: uporządkowania i sklasyfikowania różnych rodzajów konwergencji oraz pokazuje, że nie istnieje jednoznaczna definicja tego zjawiska (co jest odpowiedzią na pierwsze szczegółowe pytanie badawcze). Można się w związku z tym domyślać (co zostało empirycznie potwierdzone w rozdziale 3), że w zależności od przyjętej definicji konwergencji, wyniki weryfikacji hipotezy o występowaniu tego zjawiska mogą być inne, co jest odpowiedzią na następne pytanie badawcze, postawione w kontekście realizacji jej pierwszego celu. Odpowiedź na kolejne, z tej serii, pytanie szczegółowe - o teorie, które wyjaśniają źródła i naturę zjawiska konwergencji starano się zawrzeć w podrozdziałach 1.1-1.2 oraz 1.3.2, gdzie przywołano dwie koncepcje: neoklasyczną i endogenicznego wzrostu, które reprezentują dwa przeciwstawne bieguny, jeśli chodzi o konwergencję gospodarczą jako konsekwencję wzrostu gospodarczego. 


\section{ROZDZIAL 2}

\section{RODZAJE KONWERGENCJI WEDLUG METOD ICH WERYFIKACJI}

W rozdziale pierwszym wspomniano o różnych rodzajach konwergencji, które można wyróżnić z punktu widzenia: obszaru tematycznego badań, zasięgu terytorialnego i rodzaju badanych jednostek, ich stopnia homogeniczności, podziału gospodarki na sektory gospodarcze. W niniejszym rozdziale dokonano jeszcze jednego podziału zjawiska konwergencji - według metod jego weryfikacji, co pozwala wyróżnić konwergencję typu beta, sigma, gamma i stochastyczną ${ }^{1}$. Dopełniono w ten sposób zrealizowany częściowo w rozdziale pierwszym cel pracy polegający na uporządkowaniu i sklasyfikowaniu różnych rodzajów konwergencji.

Najważniejsze różnice dotyczą konwergencji zaliczanych do klasycznych: typu beta (omówionej w podrozdziale 2.1) i sigma (w podrozdziale 2.2). Pierwszy rodzaj oznacza, najogólniej mówiąc, doganianie (catch-up effect) początkowo bogatszych obszarów (krajów, regionów) przez biedniejsze, drugi zakłada redukcję nierówności w czasie ${ }^{2}$. Rozróżnienie pomiędzy beta- i sigma-konwergencją nabiera specjalnego znaczenia w sytuacjach, gdy wyniki badania tych dwóch rodzajów pozostają ze sobą w sprzeczności: można otrzymać dla tej samej cechy pozytywnie zweryfikowaną beta-konwergencję i brak sigma-konwergencji. Formalnie, beta-konwergencja jest warunkiem koniecznym, lecz niewystarczającym do występowania typu sigma ${ }^{3}$ (zob. Quah [1993], Sala-i-Martin [1995, 1996]), co oznacza, że sytuacja, gdy biedne regiony rozwijają się szybciej niż bogate, nie musi oznaczać zmniejszania dystansu między nimi.

Pewnym kompromisem pomiędzy tymi dwoma typami jest jeszcze inny rodzaj konwergencji - gamma-konwergencja, którą omówiono w trzeciej kolejności (w podrozdziale 2.3). Stosunkowo nowy sposób podejścia do konwergencji stanowi podejście stochastyczne, którego doniosłość w traktowaniu ekonomicznego wymiaru czasu podkreślają niektóre źródła. Ten typ konwergencji omówiono na końcu niniejszego rozdziału.

\footnotetext{
${ }^{1}$ Powyższe rodzaje konwergencji nie wyczerpują wszystkich jej typów ze względu na metody weryfikacji. Omówiono tutaj jedynie te, które wykorzystane zostały w niniejszej pracy.

${ }^{2}$ Procesy odwrotne - gdy kraje (regiony) o początkowo niższych (wyższych) wartościach badanej zmiennej charakteryzują się jej niższą (wyższą) stopą zwrotu oraz gdy zwiększa się dyspersja badanej cechy w czasie - nazywane są odpowiednio beta-dywergencją i sigma-dywergencją.

${ }^{3}$ Jednocześnie sigma-konwergencja jest wystarczającym, lecz niekoniecznym warunkiem konwergencji typu beta (co oznacza, że brak sigma-konwergencji nie pozwala jednocześnie stwierdzić, że biedniejsze początkowo kraje nie rozwijają się szybciej niż inne).
} 


\subsection{Konwergencja typu beta}

Jak już wspominano, konwergencja typu beta zachodzi, jeśli obszary o początkowo mniejszej wartości badanej cechy (np. PKB per capita) wykazują szybsze tempo wzrostu niż obszary o początkowo jej wyższej wartości. Statystycznym narzędziem weryfikacji tego faktu są najczęściej modele ekonometryczne, w których zmienną objaśnianą jest tempo wzrostu badanej cechy, a zmienną objaśniającą jej początkowa wartość. Jeśli jest to jedyna zmienna objaśniająca, to testowana jest hipoteza o występowaniu konwergencji absolutnej lub bezwarunkowej. Jeśli w modelu występują dodatkowe czynniki warunkujace wzrost to testowana jest hipoteza o konwergencji warunkowej. Jej weryfikacji dokonuje się najczęściej w ramach modelu Solowa, bowiem konwergencja jest konsekwencją stosowania neoklasycznej funkcji produkcji (por. p. 1.2), w której zakłada się malejące krańcowe produktywności kapitału (będące bezpośrednią przyczyną konwergencji). W klasycznym podejściu zaprezentowanym w pracy Barro i Sala-i-Martina [1990] zastosowano funkcję produkcji typu Cobba-Douglasa, gdzie zmienną objaśnianą było tempo wzrostu produkcji na jednostkę efektywnej pracy, a zmienną objaśniającą kapitał na jednostkę efektywnej pracy. Uogólniając model zastosowany przez wspomnianych autorów można go zapisać jako ${ }^{4}$ :

$$
\begin{aligned}
& \ln \left(\frac{y_{i t}}{y_{i, t-1}}\right)=x_{i}+\left(1-e^{-\beta}\right) x_{i, t-1}+\left(1-e^{-\beta}\right)\left[\ln \left(y_{i}^{*}\right)-\ln \left(y_{i, t-1}\right)\right]+u_{i t}, \text { lub } \\
& \ln \left(\frac{y_{i t}}{y_{i, t-1}}\right)=a_{i}-\left(1-e^{-\beta}\right)\left[\ln \left(y_{i, t-1}\right)-x_{i, t-1}\right]+u_{i t}
\end{aligned}
$$

gdzie:

$a_{i}=x_{i}+\left(1-e^{-\beta}\right) \ln \left(y_{i}^{*}\right)$,

$y_{i t}$ - wartość badanej cechy na obszarze $i$ w okresie $t$ (w oryginalnym modelu wartość produkcji na jednostkę pracy),

$x_{i t}$ - wartości dodatkowych charakterystyk badanych gospodarek $i$ w okresie $t$,

$y_{i}^{*}$ - wartość $y_{i} w$ stanie równowagi - tzw. steady-state (por. 1.2.1),

$\beta$ - szybkość zbieżności do stanu równowagi,

$u_{i t}-$ zakłócenia losowe.

\footnotetext{
${ }^{4}$ Por. Papadas, Efstratoglou [2004, s. 6].
} 
Pomijając efekty oddziaływania innych zmiennych $(x)$, powyższe równanie można przekształcić do:

$$
\ln \left(\frac{y_{i t}}{y_{i, t-1}}\right)=a_{i}-\left(1-e^{-\beta}\right)\left[\ln \left(y_{i}^{*}\right)-\ln \left(y_{i, t-1}\right)\right]+u_{i t}
$$

Jeśli dodatkowo założyć, że stany równowagi $y$ dla poszczególnych regionów $i$ są takie same, tzn. $y_{i}^{*}=y^{*}$, to można zapisać:

$$
\ln \left(\frac{y_{i t}}{y_{i, t-1}}\right)=a_{i}-\left(1-e^{-\beta}\right) \ln \left(y_{i, t-1}\right)+u_{i t}
$$

Powyższe równanie można również zapisać w postaci liniowej względem parametrów jako:

$$
\ln \left(\frac{y_{i t}}{y_{i, t-1}}\right)=a_{i}+b \ln \left(y_{i, t-1}\right)+u_{i t}
$$

gdzie: $b=-\left(1-e^{-\beta}\right)$, stąd $\beta=-\ln (1+b)$.

Równania (2.1.1)- (2.1.4) są modelami (dynamicznymi) dla danych panelowych, o których szerzej traktuje rozdział 2.1.2. Ich stosowanie ma zdecydowanie krótszą historię niż modele beta-konwergencji szacowane dla danych przekrojowych, które opisano w pierwszej kolejności - w podrozdziale 2.1.1.

\subsubsection{Empiryczna weryfikacja hipotezy o beta-konwergencji dla da- nych przekrojowych}

Do weryfikacji hipotezy beta-konwergencji przy użyciu danych przekrojowych używa się modelu objaśniającego przyrost badanej cechy w regionach $i=1, \ldots, N$, pomiędzy okresem $t_{0}$ i $t_{0}+T$ za pomocą początkowej wartości tej cechy $\mathrm{w}$ regionach ${ }^{5}$ :

$$
\ln \left(\frac{y_{i t_{0}+T}}{y_{i t_{0}}}\right)=a+b \ln \left(y_{i t_{0}}\right)+u_{i t_{0}, t_{0}+T}
$$

gdzie ujemna (dodatnia) i istotna statystycznie wartość estymatora $b$ :

\footnotetext{
${ }^{5}$ Równanie (2.1.1.1) opisuje całkowite tempo wzrostu y. Można również rozpatrywać je w wersji dla średnich (średniorocznych) temp wzrostu $y$ - por. wzór (2.1.1.4).
} 
oznacza występowanie konwergencji (dywergencji) ${ }^{6}$. Brak istotności parametru $b$ oznacza, że nie występuje ani konwergencja, ani dywergencja badanego zjawiska ${ }^{7}$.

Estymator $b$ służy najczęściej do wyliczenia kluczowego, dla konwergencji, parametru $\beta$ zwanego współczynnikiem zbieżności, który wylicza się z przekształcenia równania (2.1.1.1a), do postaci:

$$
\beta=-\ln (1+b) / T
$$

gdzie $T$ jest interwałem pomiędzy pierwszą i ostatnią obserwacją.

Znak parametru $\beta$, podobnie do $b$, informuje o występowaniu konwergencji lub dywergencji, a mianowicie, jeżeli:

- $\quad \beta<0$, zachodzi proces dywergencji (rozbieżności) pomiędzy regionami $i$, - $\quad \beta>0$, zachodzi proces konwergencji (zbieżności) pomiędzy regionami $i^{8}$.

\footnotetext{
${ }^{6}$ Czasami regresję (2.1.1.1) zapisuje się z ujemnym znakiem przed parametrem $b$ i wówczas dodatnia (ujemna) wartość $b$ oznacza konwergencję (dywergencję), zaś współczynnik zbieżności należy wyliczyć jako $\beta=-\ln (1-b) / T$.

${ }^{7}$ Badanie istotności statystycznej $b$ jest, w literaturze przedmiotu, czasami pomijane. Usprawiedliwieniem takiego postępowania może być fakt, że parametr ten wykorzystywany jest głównie do oszacowania tempa konwergencji danego wzorem (2.1.1.2) - wówczas nieistotna statystycznie wartość $b$ przełoży się na niskie tempo konwergencji (dywergencji). Należy jednakże zauważyć, że postępowanie takie jest słuszne tylko do pewnego stopnia, bowiem dla dużych wartości odchylenia standardowego $S(b)$ (w 2.1.1.1) jeden z krańców przedziału ufności dla $b$ może mieć inny znak niż parametr. W takim przypadku należy założyć, że istnieje prawdopodobieństwo, że prawdziwa wartość estymatora parametru $b$ ma nie tylko inną wartość (co wpływa na tempo zbieżności), ale również inny znak - co zmienia wniosek co do istnienia konwergencji. Istotność statystyczna $b$ daje gwarancję, że taka sytuacja nie wystąpi, lecz jednocześnie, przy standardowo przyjmowanych w badaniach ekonomicznych poziomach ufności nie niższych niż $90 \%$ powoduje, że w wielu analizach, pomimo ujemnej wartości $b$ należałoby stwierdzić brak konwergencji. W szczególności w regresjach przekrojowych dla stosunkowo niewielkich prób - np. próby 16 województw Polski - standardowe błędy estymatorów są zazwyczaj na tyle duże (ze względu na małą liczbę obserwacji-regionów występujących w mianowniku tej formuły), że często nie można potwierdzić istotności statystycznej estymatorów parametrów. W takich sytuacjach wydaje się lepszym rozwiązaniem „złagodzenie” reżimu poziomu ufności, niż nie przeprowadzanie w ogóle testów istotności.

${ }^{8} \mathrm{~W}$ praktyce, jeśli wartość $b$ z regresji (2.1.1.1) jest mniejsza od -1, wówczas na podstawie wzoru (2.1.1.2) nie można obliczyć współczynnika zbieżności (dla $b$ bliskich -1 szybkość zbieżności jest bardzo wysoka, np. dla $b=-0,99$ i $T=15$ współczynnik beta wynosi $\beta=31 \%$, a okres połowicznej zbieżności to zaledwie $h l=2,3$ roku). Wartości $b<-1$ świadczą o tak dużej szybkości zbieżności, że proces doganiania zamienia się w proces przeganiania obszarów bogatszych przez początkowo biedniejsze. Jest to zjawisko nazwane przez Sala-i-Martina [1996, s. 1329] leapfrogging lub overshooting (można się wówczas spodziewać występowania gamma-konwergencji).
} 
W kategoriach konwergencji do stanów równowagi (por. p. 1.2.1) współczynnik zbieżności $\beta$ informuje o tym, jaki procent odległości od stanu równowagi zostaje pokonany w jednym okresie (najczęściej jednym roku) lub o ile zmniejsza się w danej jednostce czasu różnica między faktyczną wartością badanej zmiennej a wartością tej zmiennej w stacjonarnym stanie równowagi (por. Malaga, Kliber [2007, s. 85]). Im wyższa wartość (co do modułu) współczynnika $\beta$, tym szybsze tempo konwergencji (dywergencji). Na podstawie współczynnika zbieżności można obliczyć tzw. half-life informujący, jaki czas jest potrzebny, aby obecne różnice zostały zredukowane o połowę?:

$$
h l=\frac{\ln 2}{\beta}
$$

W niektórych pracach, w szczególności w pracach Sala-i-Martina [1996, s. 1334]), analizuje się średni (a nie całkowity, jak w przypadku 2.1.1.1) przyrost $y_{i}$ (średnie tempo wzrostu). Wówczas równanie (2.1.1.1) ma postać:

$$
(1 / T) \ln \left(\frac{y_{i t_{0}+T}}{y_{i t_{0}}}\right)=a+b \ln \left(y_{i t_{0}}\right)+u_{i t_{0}, t_{0}+T}
$$

gdzie: $\quad b=-\frac{\left(1-e^{-\beta T}\right)}{T}$.

Dla wniosków o szybkości konwergencji $\beta$ nie ma znaczenia, czy użyto do jej oszacowania regresji (2.1.1.1), czy (2.1.1.4), należy jedynie pamiętać o właściwym obliczeniu parametru $\beta$, który w przypadku regresji (2.1.1.4) będzie miał $\operatorname{postać}^{10}$ :

${ }^{9}$ Lub, jak definiują to autorzy pracy Malaga, Kliber [2007, s. 85], wartość ta określa liczbę lat
niezbędną do zmniejszenia o połowę różnicy między wartością badanej zmiennej w regionie
$i$ w momencie $t$ a jej wartością w stacjonarnym stanie równowagi. Autorzy nazywają ten współ-
czynnik okresem połowicznej zbieżności (op.cit, s. 78).
${ }^{10}$ Dla przykładu, jeśli wartość $b$ w regresji postaci $(2.1 .1 .1)$ wynosi $b=-0,1898$, to po zastosowa-
niu wzoru (2.1.1.2) dla $T=15$ otrzyma się szybkość zbieżności rzędu $\beta=1,4 \%$ (czas redukowania
różnic o połowę wynosi $h l=49$ lat). Zastosowanie tych samych danych w regresji dla średniego (a
nie całkowitego) tempa wzrostu (2.1.1.4) prowadzi do otrzymania wartości estymatora rzędu $b=-$
0,01265 , co przy zastosowaniu wzoru (2.1.1.5) daje to samo tempo zbieżności $\beta=1,4 \%$. Nie roz-
różnianie wzorów $(2.1 .1 .2)$ i $(2.1 .1 .5)$ prowadzi do absurdalnych wyników - obliczone tempo
zbieżności za pomocą wzoru (2.1.1.2) na podstawie $b$ z regresji (2.1.1.4) daje tempo zbieżności
$\beta=0,08 \%$ co oznacza, że czas potrzebny do zredukowania różnic o połowę jest liczony w setkach
lat. W literaturze przedmiotu można spotkać jeszcze jedną postać równania (2.1.1.1):
$\frac{1}{T} \ln \frac{Y_{i t_{0}+T}}{Y_{i t_{0}}}=a+b\left(\frac{\ln y_{i t_{0}}}{T}\right)$, której zastosowanie prowadzi do otrzymania identycznego jak w (2.1.1.1) estymatora $b$ i wymaga stosowania wzoru (2.1.1.2) w celu oszacowania współczynnika zbieżności $\beta$. 


$$
\beta=-\frac{\ln (1+b T)}{T}
$$

Regresje typu (2.1.1.1) lub (2.1.1.4) ${ }^{11}$ są prostym i intuicyjnym sposobem badania konwergencji, do których można sformułować jednak pewne zarzuty (por. np. Quah [1992], Friedman [1992], Ciołek [2007]). Jednym z nich jest to, że pomija się w nich inne, niż początkowa wartość analizowanej zmiennej, cechy indywidualne każdej gospodarki. Ich pominięcie sprawia, że stanowią one czynnik zakłócający, w związku z czym warunek o nieskorelowaniu składnika losowego ze zmiennymi objaśniającymi często nie jest spełniony, co powoduje niezgodność lub obciążoność estymatorów (powoduje również niskie wartości $R^{2}$ w regresjach przekrojowych, bowiem nieuwzględnione explicite zmienne znajdują swoje odbicie w składniku losowym).

Uzupełnienie powyższych równań beta-konwergencji absolutnej o dodatkowe czynniki wzrostu $y$ prowadzi do modelu konwergencji warunkowej. Jej weryfikacji dokonuje się zazwyczaj w ramach modelu Solowa, w którym przyjmuje się najczęściej, że poziom technologii i siła robocza rosną w stałym tempie odpowiednio $g$ i n, każdy region ma swój specyficzny poziom oszczędności (inwestycji) $s_{i}$, a stopa deprecjacji kapitału $\delta$ jest stała. Można pokazać (por. Durlauf, Johnson [1995, s. 366]), że powyższe założenia prowadzą do wniosku, że dla dowolnego odstępu czasu: $t_{0}, t_{0}+T$, przyrost produkcji na zatrudnionego $y$ może być zapisany jako:

$$
\ln \left(\frac{y_{i t_{0}+T}}{y_{i t_{0}}}\right)=a+b \ln \left(y_{i t_{0}}\right)+\Pi X_{i}+u_{i t_{0}, t_{0}+T}
$$

gdzie: $X_{i}=\left[\ln \left(s_{i}\right), \ln \left(n_{i}+g+\delta\right)\right], n_{i}-$ stopa wzrostu siły roboczej w regionie $i$, $g$ - stopa postępu technicznego, $\delta$ - stopa deprecjacji kapitału, $s_{i}-$ stopa inwestycji ${ }^{12}$.

\footnotetext{
${ }^{11}$ Które nazywane są czasami w literaturze przedmiotu regresjami Barro.

${ }^{12}$ Model (2.1.1.6) może być uzupełniony o akumulację kapitału ludzkiego (wówczas $X_{i}=\left[\ln \left(s_{i}^{K}\right), \ln \left(s_{i}^{H}\right), \ln \left(n_{i}+g+\delta\right)\right]$, gdzie: $s^{K}, s^{H}$ oznaczają stopę oszczędności (inwestycji) odpowiednio w kapitał fizyczny i ludzki), co znane jest pod nazwą modelu Makiewa-RomeraWeila (MRW) lub rozszerzonego modelu Solowa.
} 


\subsubsection{Empiryczna weryfikacja hipotezy o beta-konwergencji dla danych panelowych}

W ostatnich latach coraz większą popularnością cieszy się weryfikacja hipotezy beta-konwergencji w oparciu o dane panelowe. Połączenie danych czasowych i przekrojowych w jedną próbę - panelową - pozwala znacznie zwiększyć liczbę stopni swobody modelu oraz zastosować takie metody estymacji (specyficzne dla danych panelowych), które pozwalają na uwzględnienie efektów charakterystycznych dla regionów i/lub dla czasu. Równania dla danych panelowych, pozwalające zweryfikować hipotezę o konwergencji były przywoływane na początku rozdziału 2.1. Można je rozpisać w dwóch wersjach, modelu konwergencji absolutnej:

$$
\ln \left(\frac{y_{i t}}{y_{i t-1}}\right)=a-\left(1-e^{-\beta}\right) \ln \left(y_{i t-1}\right)+\eta_{i}+v_{i}+u_{i t}
$$

lub konwergencji warunkowej:

$$
\ln \left(\frac{y_{i t}}{y_{i t-1}}\right)=a-\left(1-e^{\beta}\right) \ln \left(y_{i t 1}\right)+\delta x_{i t}+\eta_{i}+v_{i}+u_{i t}
$$

gdzie:

$y_{i t}, x_{i t}$ - jak we wzorze (2.1.1),

$\eta_{i}$ - efekty specyficzne dla poszczególnych obszarów $i$, które pokazują zróżnicowanie pomiędzy nimi wynikające $\mathrm{z}$ innych, niż uwzględnione po prawej stronie równania, czynników (które mogą być niemierzalne i dlatego nie mogą explicite zostać uwzględnione w równaniu);

$v_{t}$ - efekty okresowe dla okresu (roku) $t$, odzwierciedlają wspólne dla wszystkich obszarów wydarzenia w latach objętych analizą;

$u_{i t}$ - składnik losowy równania.

W celu oszacowania powyższych modeli stosuje się zazwyczaj postać zlinearyzowaną względem parametrów, tzn.:

$$
\begin{aligned}
& \ln \left(\frac{y_{i t}}{y_{i t-1}}\right)=a+b \ln \left(y_{i t-1}\right)+\eta_{i}+v_{i}+u_{i t}, \quad \text { lub } \\
& \ln \left(\frac{y_{i t}}{y_{i t-1}}\right)=a+b \ln \left(y_{i t-1}\right)+\delta X_{i t}+\eta_{i}+v_{i}+u_{i t}
\end{aligned}
$$

gdzie: $b=-\left(1-e^{-\beta}\right) \Rightarrow \beta=-\ln (1+b)$. 
Modele panelowe mogą przybrać postać tzw. pooled regression, dla której próbę łączy się w panel, lecz poza zwiększeniem liczby stopni swobody nie dokonuje się wyróżnienia żadnych dodatkowych efektów (model szacowany jest KMNK). Najczęściej jednak szacuje się model z efektami nielosowymi (nazywanymi czasami ustalonymi), tzw. FEM - Fixed Effects Model oraz modele $\mathrm{z}$ efektami losowymi REM - Random Effects Model ${ }^{13}$. Wyboru jednego z tych trzech typów modeli (pooled, FEM, REM) można dokonać na podstawie testów statystycznych, najczęściej: Chowa, Breucha-Pagana oraz Hausmana ${ }^{14}$.

Znamienną pracą, w której do estymacji modeli konwergencji (modeli wzrostu) użyto metod dla danych panelowych była praca Islama [1995]. Pokazał on, że tempo konwergencji wyznaczone na podstawie modeli panelowych jest szybsze niż wyznaczone na podstawie regresji przekrojowej, a oszacowane wartości elastyczności produkcji względem kapitału - niższe i bardziej akceptowalne (por. Dańska-Borsiak [2011, s.186]). W świetle dzisiejszej wiedzy wiadomo, że szacowanie modeli typu (2.1.2.3), czy (2.1.2.4) metodami typowymi dla danych panelowych (UMNK, estymator wewnątrzgrupowy, metoda Husmana-Taylora) prowadzi do obciążenia estymatorów ${ }^{15}$. Rozwój wiedzy o metodach szacowania modeli konwergencji przyniosły prace Arellano i Bonda [1991] oraz Blundella i Bonda [1998], które pokazały że estymacje panelowe nie eliminują podstawowego w analizie konwergencji problemu - endogeniczności zmiennych objaśniających i wynikających z tego błędów ich pomiaru, czy autokorelacji składnika losowego. Należy bowiem zauważyć, że modele wzrostu stosowane w analizie konwergencji są $\mathrm{w}$ istocie modelami autoregresyjnymi, bowiem można je zapisać w postaci:

$$
\ln \left(y_{i t}\right)=a+(1+b) \ln \left(y_{i t-1}\right)+\delta X_{i t}+\eta_{i}+v_{i}+u_{i t}
$$

W przypadku dynamicznej postaci modelu panelowego (jakim jest powyższe równanie), literatura zaleca stosowanie specjalnych metod estymacji. Wśród tych metod (których przegląd można znaleźć u Baltagi [1995] oraz DańskiejBorsiak [2011]), większość wykorzystuje Uogólnioną Metodę Momentów (GMM).

\footnotetext{
13 FEM pozwalają na uwzględnienie efektów specyficznych dla poszczególnych obszarów. W REM natomiast efekty indywidualne wynikają z efektów losowych i nie ulegają zmianom w czasie. Różnice między poszczególnymi regionami w REM odwzorowane są w postaci wariancji międzygrupowej błędu (por. Dańska [2000]).

${ }^{14}$ Test Chowa służy do wyboru pomiędzy modelami pooled i FEM, Breuscha-Pagana do wyboru pomiędzy modelami pooled i REM, a test Hausmana do wyboru pomiędzy modelami REM i FEM. Opis tych testów można znaleźć np. w Gruszczyński [2006, ss. 558-559; 649-650], Dańska-Borsiak [2011, ss.39-51].

${ }^{15}$ Choć szacunki tego typu mogą być wstępnym etapem analizy danych, bowiem estymatory KMNK i within wyznaczają górną i dolną granicę przedziału, w którym powinien znaleźć się zgodny i nieobciążony estymator.
} 


\subsection{Konwergencja typu sigma}

Od końca lat 80. ubiegłego wieku coraz więcej mówiło się o pewnej kontradykcji pojawiającej się w wynikach testów na konwergencję polegającej na tym, że fakt występowania beta-konwergencji (ujemnej zależności pomiędzy stopą wzrostu i początkową wartością zmiennej, będącą odzwierciedleniem idei betakonwergencji) nie musi oznaczać zmniejszania dyspersji rozkładu badanej zmiennej ${ }^{16}$. W niektórych artykułach (w szczególności Friedmana [1992] i Quaha [1993], a także Lichtenberga [1994]) sprzeciwiano się badaniom konwergencji za pomocą testów, które jedynie pokazują, że biedne regiony rozwijają się szybciej niż bogate, skoro może okazać się, że nierówności pomiędzy nimi nie ulegają zmniejszeniu. Krytyka beta-konwergencji sprzyjała zdefiniowaniu i ugruntowaniu się innej jej koncepcji: sigma-konwergencji, oznaczającej zmniejszanie się nierówności badanej cechy w czasie. Pierwszym krokiem w ocenie tego rodzaju konwergencji jest oszacowanie miary nierówności (zróżnicowania, zmienności, dyspersji, rozproszenia) badanego zjawiska wśród analizowanych obszarów w kolejnych okresach analizy. W praktyce można do tego celu wykorzystywać bardzo duży zestaw mierników, który oprócz miar rozproszenia uzupełnia się również o mierniki koncentracji (obie grupy opisane zostały w podrozdziale 2.2.1). W kroku drugim należy ocenić, czy zastosowane miary nierówności (koncentracji) badanego zjawiska istotnie zmniejszyły się w czasie (por. podrozdział 2.2.2). Jeśli tak, to występuje sigma-konwergencja.

\subsubsection{Miary nierówności}

Weryfikacja hipotezy o występowaniu sigma-konwergencji wymaga zdefiniowania miary nierówności lub koncentracji badanego zjawiska. Wybór metodologii pomiaru nasilenia nierówności pozostaje przedmiotem ciągłych rozważań. Istnieje bowiem wiele sposobów pomiaru różniących się stopniem trudności i stopniem spełnienia układu aksjomatów stawianych przed miarami nierówności (por. Laskowska [2012, s. 90]). Przegląd literatury przedmiotu pokazuje, że w badaniach sigma-konwergencji stosuje się różnego rodzaju mierniki. Poniżej dokonano przeglądu możliwych do zastosowania wzorów mierzących zarówno dyspersję, jak i koncentrację zjawisk, w tym wzory szczególnie przydatne w analizach sektorowych.

We wszystkich poniższych wzorach przyjęto następujące oznaczenia:

$y_{i t}$ - wartość cechy $y$ na obszarze $i$, w okresie $t$,

$\bar{y}_{t}-$ średnia arytmetyczna cechy $y_{i}$ (dla $i=1, \ldots, N$ obszarów) dla okresu $t$,

\footnotetext{
${ }^{16}$ Podobne zjawisko opisywane jest w paradoksie regresji w stronę średniej (paradoks Galtona), który polega na błędnej interpretacji przejściowej natury obserwacji skrajnych, jako dowodu na zmniejszanie się dyspersji rozkładu.
} 
$p_{i t} / P_{t}$ - odsetek ludności całego kraju zamieszkujących region $i$,

$N$ - liczba badanych obszarów (krajów, regionów): $i=1, \ldots, N$,

$T$ - liczba badanych okresów (najczęściej lat): $t=1, \ldots, T$.

Najprostszą miarą, często powoływaną w porównaniach międzynarodowych, mierzącą dystans pomiędzy regionem o najwyższej i najniższej wartości badanego zjawiska (np. dystans jaki dzieli gospodarki najbiedniejsze od najbogatszych) jest $D_{t}$ :

$$
D_{t}=y_{t, \max } y_{t, \min }
$$

gdzie: $y_{t, \max }, y_{t, \min }$ jest odpowiednio maksymalną i minimalną wartością badanej cechy $y$ wśród badanych $N$ regionów w danym okresie $t$.

Powyższy wskaźnik jest prostą i popularną w badaniach konwergencji miarą, uwzględnia jednak jedynie wartości skrajne (minimalne i maksymalne) badanego rozkładu. Aby uwzględnić zmiany, jakie zaszły we wszystkich analizowanych regionach stosuje się najczęściej wspótczynnik zmienności $V_{t}$ :

$$
V_{t}=\frac{S_{t}}{\bar{y}_{t}}
$$

gdzie: $S_{t}$ jest odchyleniem standardowym (pierwiastkiem kwadratowym estymatora wariancji $\sigma_{t}^{2}$ ) badanego zjawiska $y_{i t}$ wśród $N$ obiektów (regionów):

$$
S_{t}=\sqrt{\hat{\sigma}_{t}^{2}}=\sqrt{\frac{\sum_{i=1}^{N}\left(y_{i t}-\bar{y}_{t}\right)^{2}}{(N-1)}}
$$

Zamiast współczynnika zmienności stosowane jest również odchylenie standardowe logarytmów $l S_{t}$ :

$$
l S_{t}=\frac{\sqrt{\sum_{i=1}^{N}\left(\ln y_{i t}-\ln \bar{y}_{t}\right)^{2}}}{(N-1)}
$$

Obie powyższe miary dyspersji $(2.2 .1 .2-2.2 .1 .3)$ mogą być wyrażone procentowo, a zestawione dla kolejnych okresów $t$ mówią o zmianie zróżnicowania wśród badanych obszarów w czasie. Należy ich jednakże ostrożnie używać w przypadkach porównań różnych grup regionów (jak w przypadku porównań wewnętrznego zróżnicowania różnych państw), bowiem ich wartości są zależne od liczby regionów $N$ (która w różnych państwach jest inna) ${ }^{17}$. Do takich po-

${ }^{17}$ Dodatkowo, wadą odchylenia standardowego logarytmów jest to, że nie może ono być stosowane wówczas gdy wartości y przyjmują zerowe wartości. Tak się dzieje w przypadku miar syn- 
równań można użyć ważonego wspótczynnika zmienności $R V_{t}$, w którym poszczególne regiony $i$ są ważone odsetkiem ludności całego kraju zamieszkujących region $i\left(p_{i t} / P_{t}\right)^{18}$ :

$$
R V_{t}=\frac{\sqrt{\frac{p_{i t}}{P_{t}} \sum_{i=1}^{N}\left(y_{i t}-\bar{y}_{t}\right)^{2}}}{\bar{y}_{t}}
$$

Współczynnik zmienności opisany wzorem (2.2.1.2) jest także wrażliwy na obserwacje nietypowe (odchylenia od wartości średniej są podnoszone do kwadratu). Jeśli takie obserwacje występują, lepiej jest posługiwać się średnim odchyleniem $V_{a t}$ :

$$
V_{a t}=\frac{\frac{1}{N} \sum_{i=1}^{N}\left|y_{i t}-\bar{y}_{t}\right|}{\bar{y}_{t}}
$$

Odchylenie średnie, podobnie jak standardowe, należy ostrożnie stosować w przypadku porównań pomiędzy obszarami o różnej liczbie regionów $N$. Przeszkodę tę można ominąć, podobnie jak w przypadku współczynnika $V$, używając, jak we wzorze (2.2.1.4), odpowiednich wag. Zabieg ten doprowadza do formuły na relatywne średnie odchylenie $R V_{a t}$ :

$$
R V_{a t}=\frac{\sum_{i=1}^{N}\left|y_{i t}-\bar{y}_{t}\right| \frac{p_{i t}}{P_{t}}}{\bar{y}_{t}}
$$

Używaną w tej książce, ciekawą miarą zróżnicowania regionalnego, jest indeks Theila $T_{t}$ :

$$
T_{t}=\sum_{i=1}^{N}\left(\frac{y_{i t}}{Y_{t}} \ln \left(\frac{\frac{y_{i t}}{Y_{t}}}{\frac{l_{i t}}{L_{t}}}\right)\right)
$$

Indeks Theila jest ważoną (udziałami badanej cechy w danym regionie w wartości dla całego kraju: $y_{i} / Y$ ) sumą logarytmów ilorazów frakcji badanej

tetycznych, których zmienność leży w przedziale $\langle 0 ; 1\rangle$. Logarytmy wartości bliskich zeru są bardzo duże, co wpływa na zwiększenie odchylenia standardowego logarytmów i powoduje, że miara ta może mieć zupełnie inne wartości niż współczynnik zmienności.

${ }^{18}$ Należy jednakże zauważyć, że w badaniach konwergencji najczęściej same obserwacje $y_{i t}$ są już „zważone”, bowiem najczęściej oznaczają wartości przeliczone na mieszkańca (lub na pracującego). 
cechy w regionie $\left(y_{i} / Y\right)$ i frakcji pracujących w tym regionie $\left(l_{i} / L\right)^{19}$. Im wartość $T$ jest mniejsza, tym mniejsze są dysproporcje pomiędzy poszczególnymi regionami. Interesującą możliwością, szczególnie w kontekście badań nad konwergencją klubową, jest dezagregacja współczynnika Theila w różne podzbiory (np. grupy regionów). Dla $G$ podgrup (w badaniach w niniejszej książce województwa Polski są dzielone na 3 lub 4 grupy, tzn. $G=3$ lub $G=4$ ), o liczebnościach $S_{g}$ (w przypadku podziału Polski na $G=3$ podgrupy województw liczebności poszczególnych grup mogą być następujące $S_{1}=5, S_{2}=5, S_{3}=6$ ) współczynnik Thaila można zapisać jako:

$$
T_{t}=\sum_{i=1}^{N}\left(\frac{y_{i t}}{Y_{t}} \ln \left(\frac{\frac{y_{i t}}{Y_{t}}}{\frac{l_{i t}}{L_{t}}}\right)\right)=\left(\sum_{g=1}^{G} \frac{y_{g t}}{Y_{G t}} \ln \frac{\frac{y_{g t}}{Y_{t}}}{\frac{l_{g t}}{L_{t}}}\right)+\left(\sum_{g=1}^{G} \sum_{r=1}^{S} \frac{S_{i t}}{Y_{G t}} \ln \frac{\frac{y_{i t}}{y_{g t}}}{\frac{l_{i t}}{l_{g t}}}\right)=T_{g t}+T_{r t}
$$

gdzie:

$y_{g t} / Y_{t}$ - udział wartości badanej cechy (np. wartości dodanej brutto) w grupie regionów $g$ (suma wartości w regionach składających się na daną grupę) w całkowitej wartości cechy $Y$ w okresie $t$,

$l_{g t} / L_{t}-$ udział pracujących $\mathrm{w}$ grupie regionów $g$ (suma liczby pracujących w regionach składających się na daną grupę) w liczbie pracujących w kraju w okresie $t$,

$y_{i t} / y_{g t}-$ udział wartości badanej cechy $y w$ regionie $i \mathrm{w}$ wartości tej cechy dla grupy regionów $g$ w okresie $t$,

$l_{i l} / l_{g t}$ - udział liczby pracujących w regionie $i$ w liczbie pracujących w grupie regionów $g w$ okresie $t$,

$T_{g t}$ - zróżnicowanie międzygrupowe, wynikające ze zróżnicowania pomiędzy $g$ grupami regionów w okresie $t$,

$T_{r t}-$ zróżnicowanie wewnątrzgrupowe w poszczególnych $g$ grupach regionów W okresie $t$,

$g=1, \ldots, G$, gdzie $G$ oznacza liczbę grup (klubów, klastrów) regionów, $r=1, \ldots, S_{g}$, gdzie $S_{g}$ oznacza liczbę regionów w grupie $g$.

Dekompozycja współczynnika Thaila $T_{t}$ postaci (2.2.1.8) pozwala zarówno śledzić zmiany zróżnicowania międzygrupowego $T_{g t}$ i wewnątrzgrupowego $T_{r t}$ jak i obliczać udział różnic wewnątrzgrupowych oraz różnic międzygrupowych w całkowitym zróżnicowaniu ${ }^{20}$.

\footnotetext{
${ }^{19}$ Najczęściej indeks Thaila odnosi się do frakcji ludności (a nie pracujących) danego regionu. Ponieważ jednak badania w niniejszej pracy koncentrują się przede wszystkim na współczynnikach wyrażonych na pracującego (a nie na mieszkańca) podano już tak zmodyfikowaną formułę.

${ }^{20}$ Należy zauważyć, że współczynniki Thaila, w przeciwieństwie do poprzednich miar, należy stosować jedynie do zmiennych nie przeliczonych na liczbę mieszkańców, czy pracujących (wynika to $\mathrm{z}$ faktu, że wielokrotnie wykorzystuje się w nim udział badanej zmiennej w danym regio-
} 
W badaniach nad konwergencją zamiast klasycznych miar dyspersji stosuje się coraz częściej miary koncentracji, w szczególności wspótczynnik Giniego ${ }^{21}$ (który jest stosowany przede wszystkim w analizach rozkładu dochodów lub bogactwa poszczególnych regionów, krajów - por. np. Martin, Sanz [2003], Monfort [2008]) $)^{22}$ :

$$
G_{t}=\left(\frac{1}{2 \bar{y}_{t}}\right) \frac{1}{N(N-1)} \sum_{i}^{N} \sum_{m}^{N}\left|y_{i t}-y_{m t}\right|
$$

lub

$$
G_{t}=\frac{2}{N^{2} \bar{u}_{i t}} \sum_{i=1}^{N}\left[\left(i-\frac{N+1}{2}\right) u_{i t}\right]
$$

gdzie: $u_{i t}$ - oznacza udział cechy $y$ w regionie $i, m(i, m=1, \ldots N)$ w wartości tej cechy dla sumy regionów.

Współczynnik Giniego przyjmuje wartości z przedziału od 0 do 1 (gdzie 0 oznacza doskonałą równość, a 1 - pełną nierówność rozkładu cechy y wśród badanych regionów).

\section{Mierniki specjalizacji regionalnei}

$\mathrm{W}$ badaniach sektorowych specjalnego znaczenia nabierają mierniki specjalizacji regionalnej. Z powyżej opisanych mierników zarówno indeks Giniego, jak $\mathrm{i}$ indeks Theila mają szerokie zastosowanie $\mathrm{w}$ analizie koncentracji przestrzennej, zwłaszcza w badaniach nad koncentracją poszczególnych gałęzi przemysłu w regionach (por. Suchecki, red.,[2010, ss. 132-161]), czy ogólnie koncentracją danego sektora gospodarczego. Należy jednocześnie zaznaczyć, że wszystkie miary opisane wzorami (2.2.1.1) - (2.2.1.10) mogą być stosowane do badania dyspersji i koncentracji w wybranym sektorze gospodarki. Jeśli jednak celem jest obserwowanie jednocześnie zmian $w$ regionach i sektorach warto zastosować specjalne wskaźniki, które opisano poniżej i które nazwać można ogólnie indeksami specjalizacji regionalnej.

nie w wartości agregatowej, co nie miałoby sensu w przypadku takich wskaźników jak PKB per capita, czy WDB na pracującego).

${ }^{21} \mathrm{~W}$ przypadku danych przestrzennych jednym z podstawowym narzędzi badania jest krzywa Lorenza. W wariancie klasycznym, gdy wszystkie regiony, w których rozmieszczone są wartości analizowanej zmiennej są identyczne, krzywa Lorenza pokazuje skumulowane udziały wartości badanej zmiennej. Syntetyczną miarą koncentracji w wielkościach absolutnych, wynikającą z geometrycznej konstrukcji empirycznej krzywej Lorenza, jest indeks Giniego, który jest funkcją aproksymacyjną powierzchni pola wyznaczanego przez krzywą Lorenza (por. Suchecki, red., [2010, s. 132-161]).

${ }^{22}$ Pierwszy wzór należy stosować, jeśli badana cecha ma postać wskaźnika np. regionalne PKB per capita (wtedy podstawą obliczeń są odleglości pomiędzy tymi wskaźnikami w poszczególnych regionach), drugi, gdy analizujemy wartości w postaci bezwzględnej, np. regionalne PKB (wówczas brana jest pod uwagę ważona suma udziału cechy w badanym regionie). 
Jedną z prostszych miar stosowanych w przestrzennych badaniach sektorowych jest relatywny indeks koncentracji (Relative Concentration Index) dla sektora gospodarki $j^{23}$ :

$$
R C I_{j}=\frac{1}{2} \sum_{i=1}^{N}\left|\frac{y_{i j}}{Y_{i}}-\frac{Y_{i}}{Y}\right|
$$

gdzie:

$y_{i j}$ - wartość badanej cechy w regionie $i$ oraz sektorze $j$ (np. udział WDB rolnictwa w województwie dolnośląskim),

$Y_{i}$ - całkowita wartość cechy w regionie $i$ (np. WDB w województwie dolnośląskim),

$Y_{j}$ - wartość cechy w sektorze $j$ dla sumy regionów $i$ (np. WDB rolnictwa w Polsce),

$Y$ - całkowita wartość cechy dla sumy regionów $i$ i sumy sektorów $j$ (np. WDB w Polsce),

$i=1, \ldots, N$, gdzie $N$ oznacza liczbę wszystkich analizowanych regionów (np. $N=16$ województw Polski),

$j=1, \ldots S$, gdzie $S$ oznacza liczbę wszystkich analizowanych sektorów (np. $S=3$ dla trzech sektorów gospodarki: rolnictwo, przemysł, usługi).

Powyższy indeks przyjmuje wartości z przedziału od 0 do 1 , gdzie 0 oznacza rozproszenie cechy $\mathrm{w}$ danym sektorze $\mathrm{w}$ regionach podobne do ogólnonarodowego, czyli brak koncentracji.

W przypadku konstrukcji indeksów przestrzennej koncentracji aktywności ekonomicznej dla regionów dużą popularnością cieszą się indeksy specjalizacji regionalnej oparte na ilorazach lokacyjnych $L Q$, które są miarą stopnia koncentracji danej cechy na danym obszarze w porównaniu do obszaru referencyjnego (np. udział zatrudnienia w rolnictwie w województwie dolnośląskim w porównaniu do analogicznego udziału dla Polski). Wartości ilorazu powyżej 1 oznaczają większą koncentrację danej sfery działalności w regionie w porównaniu do Polski i mogą wskazywać na specjalizację regionalną ${ }^{24}$. Ilorazy lokacyjne $L Q_{i j}$ definiowane są wzorem:

\footnotetext{
${ }^{23}$ Por. Papadas, Efstratoglou [2004, s. 9]. Od tego wzoru zrezygnowano z umieszczania subskryptu $t$, który we wzorach (2.1.1.1)-(2.1.1.10) miał podkreślać, że dana miara zmienia się dla różnych okresów badania (ideą sigma-konwergencji jest właśnie ocena zmian w czasie poszczególnych mierników dyspersji międzyregionalnej). Ze względu na konieczność wprowadzenia w wzorach (2.2.1.11) - (2.2.1.15) subskryptów różnicujących je ze względu na region $i, m$ (i, $m=1, \ldots, N)$ oraz sektor $j(j=1, \ldots, S)$ zrezygnowano już z subskryptu $t$, choć należy zaznaczyć, że do oceny sigma-konwergencji wartości te powinny być liczone osobno dla każdego okresu analizy $t(t=1, \ldots, T)$.

${ }^{24}$ Niektórzy autorzy przyjmują, że dopiero, gdy wartość $L Q>1,25$, można mówić o regionalnej koncentracji danej cechy.
} 


$$
L Q_{i j}=\frac{y_{i j} / Y_{i}}{Y_{j} / Y}
$$

gdzie:

$L Q_{i j}$ - iloraz lokacyjny dla regionu $i$ oraz sektora (sekcji) $j$ mówiący, o ile procent udział badanej cechy w regionie jest wyższy (dla $L Q>1$ ) lub niższy (dla $L Q<1)$ od analogicznego udziału dla Polski, reszta oznaczeń jak w (2.2.1.11).

W stosunku do ilorazów lokacyjnych można stosować wszystkie miary zróżnicowania wymienione na początku paragrafu 2.2.1, jak i miary koncentracji, które wymieniono poniżej.

Wartości współczynników Giniego liczone na podstawie ilorazów lokacyjnych nazywane są indeksami koncentracji Giniego lub lokalizacyjnymi indeksami Giniego:

$$
L Q I=\frac{\Delta}{4 L \bar{Q}_{i j}}, \Delta=\frac{1}{N(N-1)} \sum_{i=1}^{N} \sum_{m=1}^{N}\left|L Q_{i j}-L Q_{m j}\right|
$$

gdzie:

$L Q_{i j}, L Q_{m j}$ - ilorazy lokacyjne dla sektora $j$ oraz regionu $i, m(i, m=1, \ldots, N)$.

Lokalizacyjny indeks Giniego charakteryzuje się zmiennością z przedziału $(0 ; 0,5)$, gdzie 0 oznacza, że regionalna struktura działalności ekonomicznej w $j$ tym sektorze jest identyczna ze strukturą krajową zaś wartość 0,5 oznacza, że badana działalność jest całkowicie skoncentrowana na jednym obszarze (por. Suchecki, red., [2010, s. 140]).

Indeks Herfindahla-Hirschmana jest często używany w ekonomice przemysłu dla pomiaru koncentracji produkcji według przedsiębiorstw. Generalnie jest miarą koncentracji rynku określającą poziom „zagęszczenia” w danej branży. Jest ważoną sumą kwadratów współczynników lokalizacji ${ }^{25}$ :

$$
H H I_{j}=\frac{1}{N} \sum_{i=1}^{N}\left[s_{i}\left(L Q_{i j}\right)^{2}\right]
$$

gdzie:

$s_{i}$ - udział sektora $j w$ regionie $i$,

$L Q_{i j}$ - iloraz lokacyjny dla sektora $j$ oraz regionu $i$.

Wartość minimalna jest odwrotnością liczby regionów $(1 / N)$ i oznacza, że działalność badanego sektora jest stosunkowo równomiernie rozłożona pomiędzy regionami. Wartość maksymalna wynosi 1 i oznacza, że działalność badanego sektora jest skupiona $\mathrm{w}$ jednym regionie ${ }^{26}$.

\footnotetext{
${ }^{25}$ Por. Suchecki, red., [2010, s. 144].

${ }^{26}$ Indeks $H H I$ był oryginalnie stosowany do określenia poziomu konkurencji na rynku. Wówczas jest on definiowany jako suma kwadratów udziałów w sprzedaży wszystkich przedsiębiorstw
} 
Indeks Herfindahla-Hirshhmana jest wykorzystywany przez indeks EG (Ellison and Glaeser inde ${ }^{27}$ ) postaci:

$$
E G_{j}=\frac{G_{j}-\left(1-\sum_{i=1}^{N} y_{r}^{2}\right) H H I_{j}}{\left(1-\sum_{i=1}^{N} y_{i}^{2}\right)\left(1-H H I_{j}\right)}
$$

gdzie: $G_{j}=\sum_{i=1}^{N}\left(s_{i}-y_{i}\right)^{2}$ jest indeksem geograficznej koncentracji sektora $j, s_{i}-$ udział sektora $j \mathrm{w}$ regionie $i, y_{i}-$ udział zatrudnienia w regionie $i, H H I_{j}-$ indeks Herfindhala-Hirschmana dla sektora $j^{28}$.

Indeks $E G$ mierzy koncentrację wybranego sektora gospodarki po usunięciu efektu rozmiaru przedsiębiorstw (czasami nazywanego koncentracją przemysłową $)^{29}$. Jeśli dany sektor wykazuje wysoką koncentrację jako efekt występowania dużych przedsiębiorstw, wtedy indeks $E G$ jest równy 1.

\subsubsection{Weryfikacja hipotezy o sigma-konwergencji}

Zgodnie $\mathrm{z}$ tym, co napisano na początku podrozdziału 2.2, sigma-konwergencja występuje, jeśli można pokazać, że rozproszenie (ale też koncentracja) badanej cechy spada. Do tego celu można użyć wszystkich wymienionych w poprzednim paragrafie miar dyspersji i koncentracji, niemniej najbardziej intuicyjną metodą zweryfikowania tego faktu jest (zaproponowane w pracy Lichtenberga [1994]) porównanie wariancji zjawiska w skrajnych okresach (tzn. pierwszym i ostatnim) ${ }^{30}$. Jeśli można wykazać, że wariancja na końcu analizowanego okresu jest istotnie niższa niż na początku, możemy mówić o sigma-konwergencji. W przeciwnym wypadku, tzn. gdy wariancja na końcu okresu jest istotnie wyższa, mówimy o sigma-dywergencji. W celu formalnego zbadania występowania sigma-konwergencji (sigma-dywergencji), należy zweryfikować następujący zespół hipotez:

(a nie regionów). Wartość najwyższa (1) określa przypadek monopolu, najniższa $(1 / N)$ konkurencję doskonałą, a dynamika $H H I$ pozwala badać zmiany siły producentów i konkurencyjności na rynku.

${ }^{27}$ Por. Ellison i Glaeser [1997].

${ }^{28}$ Ellison i Glaeser [1997] odróżniają przy tym efekt rozmiaru przedsiębiorstw, ponieważ celem ich badania było odróżnienie części koncentracji wynikającej z aktywności ekonomicznej, która jest zgodna z koncentracją przemysłową (na przykład sektor, w którym $80 \%$ pracowników pracuje w dwóch dużych firmach) od koncentracji, która jest wyjaśniana przez tzw. wymuszenia aglomeracyjne. Indeks ten może przybrać dowolny znak. Jeśli jest on ujemny, to aktywność ekonomiczna badanego sektora jest mniej skoncentrowana niż ogólne zatrudnienie. Wartość dodatnia występuje, jeśli istnieją „wymuszenia aglomeracyjne” dla danego sektora.

${ }^{29} \mathrm{~W}$ przypadku badań przeprowadzonych w niniejszej książce należałoby raczej mówić o usunięciu efektu rozmiaru regionów.

${ }^{30} \mathrm{~W}$ praktyce porównuje się estymatory $-S^{2}-$ wariancji $-\sigma^{2}$ (por. wzór 2.2 .1 .2 ). 
$H_{0}: \sigma_{1}^{2}=\sigma_{T}^{2}=\sigma^{2}$ (brak konwergencji i dywergencji),

$H_{1}: \sigma_{1}^{2}>\sigma_{T}^{2}$ (występuje konwergencja) lub

$H_{1 a}: \sigma_{1}^{2}<\sigma_{T}^{2}$ (występuje dywergencja),

gdzie: $\sigma_{1}^{2}, \sigma_{T}^{2}$ oznaczają odpowiednio wariancję badanej cechy wśród $N$ badanych obszarów w pierwszym i ostatnim okresie badania.

Do zweryfikowania powyższych hipotez służy statystyka ${ }^{31}$ :

$$
T_{1}=\frac{\hat{\sigma}_{1}^{2}}{\hat{\sigma}_{T}^{2}}
$$

która ma rozkład $F$-Snedecora z $(N-2, N$-2) stopniami swobody. Wartości wyższe od wartości krytycznych pozwalają na odrzucenie hipotezy zerowej mówiącej o równości wariancji (a więc o braku konwergencji na korzyść hipotezy o konwergencji $-H_{1}$ lub dywergencji- $H_{1 \mathrm{a}}$ ).

Niektórzy autorzy twierdzą, że powyższy test nie bierze pod uwagę zależności pomiędzy badanymi wariancjami i, w związku z tym, jest obarczony popełnieniem błędu II rodzaju (niepoprawnego odrzucenia hipotezy o występowaniu konwergencji). Ma to znaczenie szczególnie dla niewielkich prób (a do takich należy zaliczyć próbę 16 województw analizowanych w części empirycznej niniejszej pracy). Caree i Klomp [1997] do zweryfikowania hipotez o równości wariancji proponują statystyki $T_{2}$ i $T_{3}$, które, zdaniem autorów, są wolne od powyższego obciążenia (można je stosować nawet dla krótkich prób).

Statystyka $T_{2}$ ma postać:

$$
T_{2}=(N-2,5) \ln \left[1+\frac{1}{4} \frac{\left(\hat{\sigma}_{1}^{2}-\hat{\sigma}_{T}^{2}\right)^{2}}{\hat{\sigma}_{1}^{2} \hat{\sigma}_{T}^{2}-\hat{\sigma}_{1 T}^{2}}\right]
$$

gdzie: $\hat{\sigma}_{1 T}$ jest kowariancją obliczaną dla pierwszego i ostatniego roku badania: $\hat{\sigma}_{1 T}=\sum_{i}\left(y_{i 1}-\bar{y}_{1}\right)\left(y_{i T}-\bar{y}_{T}\right) / N$. Statystyka (2.2.2.2) ma rozkład $\chi^{2}(1)$.

Statystyka $T_{3}$ ma postać:

$$
T_{3}=\frac{\sqrt{N}\left(\hat{\sigma}_{1}^{2} / \hat{\sigma}_{T}^{2}-1\right)}{2 \sqrt{1-\hat{\pi}^{2}}}
$$

gdzie: $\hat{\pi}$ jest estymatorem z równania: $y_{i T}=\pi y_{i 1}+u_{i}{ }^{32}$.

\footnotetext{
${ }^{31}$ Wzór 2.2.2.1 dotyczy sytuacji, gdy wariancja maleje w czasie: wtedy licznik jest większy od mianownika. Jeśli wariancja rośnie w czasie (wyższa jest wariancja dla końcowego okresu, a niższa dla początkowego) wówczas testowana jest hipoteza o dywergencji, a składniki ilorazu (2.2.2.1) należy odwrócić (tak, aby w liczniku pojawiła się wyższa wartość).
} 
Statystka (2.2.2.3) ma standaryzowany rozkład normalny. Powyższy test, zaproponowany przez Caree i Klomp [1997] do testowania konwergencji można zmodyfikować do celów testowania również dywergencji. Otóż w przypadku, gdy wariancja rośnie w czasie tzn. gdy $\hat{\sigma}_{1}^{2}<\hat{\sigma}_{T}^{2}$ wówczas statystyka $T_{3}$ jest ujemna, lecz wydaje się możliwe wówczas zastosowanie wartości bezwzględnej statystyki i następujący sposób wnioskowania: jeśli $\left|T_{3}\right|>1,64$ (ostatnia wartość jest wartością krytyczną rozkładu normalnego dla 5\% poziomu istotności), to występuje dywergencja dla $\hat{\sigma}_{1}^{2}<\hat{\sigma}_{T}^{2}$ oraz konwergencja dla $\hat{\sigma}_{1}^{2}>\hat{\sigma}_{T}^{2}$.

Carre i Klomp [1997], dokonali porównania wyników dotyczących konwergencji liczonej na podstawie wzorów (2.2.2.2) i (2.2.2.3) z wcześniej przytaczanymi przez Lichtenberga [1994] wykorzystującego wzór (2.2.2.1). Badanie dotyczyło konwergencji produktywności w 22 krajach OECD dla lat 1950-1994 i potwierdziło, że w okresie tym konwergencja występowała. Jednakże dla okresu 1960-1985 (który był przedmiotem badań Lichtenberga) statystyka $T_{1}$ sugeruje brak konwergencji PKB per capita, podczas gdy dwie pozostałe statystyki sugerują jej występowanie. Powodem tej rozbieżności jest stosowanie statystyki $T_{1}$ dla krótkich okresów i związane z tym, prawdopodobieństwo popełnienia błędu II rodzaju.

Sposób testowania sigma konwergencji za pomocą statystyk (2.2.2.1) - (2.2.2.3) pomija zmiany w badanym zjawisku, które występują pomiędzy skrajnymi okresami analizy. Badanie konwergencji typu sigma można wspomóc wizualizacją miar zróżnicowania w poszczególnych okresach na wykresie, który pomaga ocenić, czy spadek zróżnicowania ma charakter ciągły, czy nie. Dla tak stworzonego szeregu danych (składającego się z miar zmienności badanego zjawiska np. regionalnego PKB per capita dla poszczególnych lat) można zastosować linowy model trendu postaci:

$$
S_{y t}=\alpha_{0}+\alpha_{1} t+\xi_{t}
$$

gdzie:

$S_{y t}$ - jest miarą rozproszenia lub koncentracji (dowolną miarą opisaną w podrozdziale 2.2.1) badanej zmiennej y między poszczególnymi obszarami (krajami, regionami) w okresie $t(t=1, \ldots, T), \alpha_{0}, \alpha_{1}$ - parametry strukturalne, $\xi_{t}-$ składnik losowy równania, $t$ - zmienna czasowa.

32 Równanie beta-konwergencji można zapisać w postaci: $y_{i T}-y_{i 0}=b y_{i 1}+u_{i}$, gdzie $\pi=(1+b)$. w przypadku, gdy pomiędzy stopą wzrostu a początkową wartością jest zależność ujemna, tzn. gdy $b<0$, wówczas $\pi \in(0 ; 1)$. Dla dodatniej korelacji pomiędzy stopą wzrostu i początkową wartością badanego zjawiska, wzór (2.2.2.3) nie może być zastosowany, bowiem liczba podpierwiastkowa w mianowniku (2.2.2.3) byłaby ujemna. 
Na podstawie równania (2.2.2.4) wnioskujemy o konwergencji typu sigma, jeśli parametr $\alpha_{1}$ jest ujemny i istotny statystycznie ${ }^{33}$.

\subsubsection{Zależność pomiędzy beta i sigma-konwergencją oraz efekty przestrzenne}

Wnioski z badania sigma- i beta-konwergencji nie muszą być zbieżne (co się często zdarza w przypadku analiz przeprowadzanych w niniejszej książce). Wynika to z przytaczanego już twierdzenia, że konwergencja beta jest warunkiem koniecznym, jednak nie wystarczającym, istnienia konwergencji typu sigma. Pokazał to Sala-i-Martin, który w swoim artykule z 1996 r. (Sala-iMartin [1996, s. 1329]) wykazał, że zależność pomiędzy wariancją badanej cechy a współczynnikiem zbieżności $\beta$ jest następująca:

$$
\sigma_{y t}^{2}=(1-\beta)^{2} \sigma_{y t ~}^{2}+\sigma_{u}^{2}
$$

gdzie: $\sigma_{y t}^{2}$ - wariancja $\ln \left(y_{i t}\right), \sigma_{u}^{2}$ - niezależna od czasu wariancja składnika losowego w (2.1.4). Dla $0<\beta<1$ (a więc, gdy występuje beta-konwergencja) powyższy proces jest stacjonarny, zaś dla $\beta<0$ (brak beta-konwergencji) proces jest niestacjonarny, a wariancja rośnie w czasie (dlatego właśnie betakonwergencja jest warunkiem koniecznym sigma-konwergencji). Równanie (2.2.3.1) pokazuje również, że wariancja rośnie wraz ze wzrostem składnika losowego w (2.1.1.1), czyli również, a czego nie podkreśla się wyraźnie w literaturze, wraz ze spadkiem $\mathrm{R}^{2}$ równania. Steady-state dla wariancji postaci (2.2.3.1) w artykule Sala-i-Martina [1996, s. 1329] jest dane wzorem:

$$
\left(\sigma^{2}\right)^{*} \cong \frac{\sigma_{u}^{2}}{1-(1-\beta)^{2}}
$$

z czego wynika, że wariancja steady-state rośnie wraz z wariancją składnika losowego $\sigma_{u} \mathrm{w}$ (2.1.4) i spada wraz ze wzrostem $\beta$.

Wg autorki wzorem, który miałby bardziej praktyczne, niż (2.2.3.2) zastosowanie, jest powiązanie steady-state nie tyle ze składnikiem losowym, co z popularnym współczynnikiem $\mathrm{R}^{2}$. Uczyniono to poniżej.

Skoro:

$$
R^{2}=1-\frac{\sum\left(y_{t}-\hat{y}_{t}\right)^{2}}{\sum\left(y_{t}-\bar{y}\right)^{2}}=1-\frac{\sigma_{u}^{2}}{\sigma_{y}^{2}} \Rightarrow \sigma_{u}^{2}=\sigma_{y}^{2}-R^{2} \sigma_{y}^{2}
$$

to:

\footnotetext{
${ }^{33}$ Parametr $\alpha_{1}$ ma również sensowną interpretację ekonomiczną. Mówi o tym, o ile rośnie (dla estymatora $\left.\alpha_{1}>0\right)$ lub spada $\left(\alpha_{1}<0\right)$ rozproszenie (lub koncentracja, w zależności od użytego miernika $S$ ) pomiędzy obszarami średnio z okresu na okres (najczęściej z roku na rok). Badanie sigmakonwergencji poprzez analizę trendu we współczynniku zmienności zostało zaproponowane przez Friedmana [1992].
} 


$$
\left(\sigma^{2}\right)^{*}=\frac{\sigma_{y}^{2}-R^{2} \sigma_{y}^{2}}{1-(1-\beta)^{2}}
$$

Ze wzoru (2.2.3.2a) wynika, że $\left(\sigma^{2}\right)^{*}$ maleje wraz ze wzrostem $\mathrm{R}^{2}$ w regresji beta-konwergencji. Wynika $\mathrm{z}$ tego praktyczny wniosek: im niższe $\mathrm{R}^{2}$ $\mathrm{w}$ równaniu pozytywnie weryfikującym beta-konwergencję, tym większe prawdopodobieństwo, że test sigma-konwergencji zostanie zweryfikowany negatywnie.

Wykorzystując równania (2.2.3.1) i (2.2.3.2) można również zapisać (por. Salai-Martin, [1996, s. 1330]):

$$
\sigma_{y t}^{2}=\left(\sigma^{2}\right)^{*}+(1-\beta)^{2}\left[\sigma_{y t-1}^{2}-\left(\sigma^{2}\right)^{*}\right]
$$

Jeśli występuje beta-konwergencja, to wariancja osiąga swój stan równowagi monotonicznie. Kluczowy jest jednakże fakt, że wariancja może zarówno rosnąć, jak i spadać w kierunku punktu równowagi (steady-state) w zależności od tego, czy początkowe wartości leżą poniżej, czy powyżej tego punktu. To ostatnie równanie pokazuje, że beta-konwergencja jest koniecznym lecz niewystarczającym warunkiem dla $\sigma$-konwergencji (por. Sala-i-Martin [1996, ss. 13291330]).

Na koniec uwaga o efektach przestrzennych, do których przywiązuje się coraz większą rolę (większość opublikowanych ostatnio prac B. Baltagi, których wykaz znajduje się na http://econpapers.repec.org/RAS/pba9.htm, porusza problem efektów przestrzennych). W literaturze podaje się (por. Rej, Dev [2006], [za:] LeGallo, Dall'erba [2008, s. 506]), że wariancja próby znacząco przeszacowuje zróżnicowanie populacji, jeśli w danych obecne są efekty przestrzenne. Należy jednakże zauważyć, że to, co podlega ocenie w testach konwergencji, to nie tyle wielkość samej wariancji, co jej zmienność w czasie. Zdaniem autorki, należy zatem oczekiwać, że jeśli jest ona przeszacowana z powodu występowania efektów przestrzennych, to jest to efekt widoczny w każdym momencie badania - co nie powinno znacząco wpłynąć na wyniki badania sigma-konwergencji. Natomiast uwzględnienie efektów przestrzennych w teście beta-konwergencji zwiększa szybkość konwergencji (por. LeGallo, Dall'erba [2008, s. 517]). W niniejszej pracy analizy prowadzone są dla danych wojewódzkich, dla których nie spodziewano się uzyskać jakiś istotnych zależności przestrzennych, niemniej zbadano ten efekt w odniesieniu do podstawowych danych (potwierdzając brak takich efektów dla wojewódzkich PKB per capita i WDB na pracującego). 


\subsection{Konwergencja typu gamma}

Jak już wspominano, pod koniec lat 80 . XX w. pojawiły się głosy, że to nie doganianie (catch-up) będące postawą beta-konwergencji (opisanej w p. 2.1), lecz malejące zróżnicowanie w poszczególnych latach, czyli $\sigma$-konwergencja (opisana w p. 2.2) powinna być podstawą do wnioskowania o konwergencji. Odpierając te zarzuty, Sala-i-Martin [1994] argumentował, że konwergencja jest szeroką koncepcją, która dotyczy oceny mobilności poszczególnych obszarów w czasie w ramach rozkładu badanej cechy (np. dochodów per capita). Sala-iMartin zrównuje jednocześnie ten intra-rozkład mobilności z koncepcją betakonwergencji. Jeśli taka interpretacja Sala-i-Martina [1994] beta-konwergencji jest właściwa, to równie właściwe wydaje się zbadanie zmian w rankingu badanych obiektów. Podejście to, zaprezentowane przez Boyle'a i McCarthy'iego [1997a, ss. 257-264], nazywane jest gamma-konwergencja. Autorzy cytowanej pracy ponownie przeliczyli dane z artykułu Barro i Sala-i-Martina [1992] i pokazali, że w przeciwieństwie do wniosków Barro i Sala-i-Maritna nie można stwierdzić konwergencji pomiędzy krajami OECD wokresie po roku 1972. Sprzeczność tę Boyle, McCarthy [1997a, s. 263] wyjaśniają obciążeniem estymatorów, które dla podejścia Barro i Sala-i-Martina jest 20 razy większe niż w przypadku podejścia konkordancji rang, będącego podstawą gammakonwergencji.

\subsubsection{Weryfikacja hipotezy o gamma-konwergencji za pomocą testu Boyle'a-McCathy'ego}

W teście Boyla-McCathy'ego, w celu stwierdzenia, ze obszary o niższej wartości rangi wyprzedziły obszary o początkowo jej wyższej wartości, dokonuje się analizy uporządkowań obiektów w różnych okresach badania. Aby dokonać takiej analizy, należy uszeregować poszczególne obszary wg badanej cechy rosnąco lub malejąco, następnie zbadać, czy po upływie pewnego czasu nastąpiło „przerangowanie” obszarów. W celu weryfikacji tej hipotezy Boyle i McCathy (op.cit) proponują wykorzystanie współczynnika zgodności (konkordancji) rang Kendalla. W przypadku użycia tej miary do badania konwergencji (zazwyczaj jest ona wykorzystywana do analizy danych pochodzących z wielu źródeł, np. od różnych osób lub, jak w niniejszej książce, z różnych województw), rangi (tzn. liczby porządkowe wg rosnącej lub malejącej wartości cechy np. dla województw Polski liczby od 1 do 16) przyporządkowuje się każdemu regionowi (uwzględnionemu w badaniu) w kolejnych latach badania (np. PKB per capita dla województwa mazowieckiego będzie miało rangę 1 we wszystkich latach 
badania). Następnie należy obliczyć wspótczynnik konkordancji rang Kendalla, o następującej postaci ${ }^{34}$ :

$$
R C_{t}=\frac{\operatorname{wariancja}\left(\sum_{t=0}^{T} A R(Y)_{i t}\right)}{\operatorname{wariancja}\left((T+1) \times A R(Y)_{i 0}\right)}
$$

gdzie:

$A R(Y)_{i t}$ - ranga (pozycja) badanego regionu $i$ pod względem badanej cechy W okresie $t$,

$A R(Y)_{i 0}$ - ranga (pozycja) badanego regionu $i$ pod względem badanej cechy w okresie początkowym $t=0$,

$T$ - interwał pomiędzy pierwszym i ostatnim okresem badania $(T+1$ - liczba lat badania).

Współczynnik ten można również zapisać w postaci tzw. binarnej (kiedy do badania używa się tylko skrajnych okresów: pierwszego i ostatniego):

$$
R C_{\text {bin }}=\frac{\text { wariancja }\left(A R(Y)_{i t}+A R(Y)_{i 0}\right)}{\operatorname{wariancja}\left(2 * A R(Y)_{i 0}\right)}
$$

Współczynnik (2.3.1.1) i (2.3.1.2) mierzy zgodność rang w przedziale $(0,1)$. Im bliższa zeru jest wartość współczynnika konkordancji, tym zmiany wewnątrz rozkładu są większe - występuje konwergencja. Jeśli współczynnik przyjmuje wartość 1, oznacza to brak jakichkolwiek zmian - brak konwergencji ${ }^{35}$. Zespół weryfikowanych hipotez może być zapisany jako:

$H_{0}: R C_{T}\left(R C_{b i n}\right)=0$ (występuje gamma-konwergencja),

$H_{1}: R C_{T}\left(R C_{b i n}\right) \neq 0$ (brak gamma-konwergencji).

Do zweryfikowania powyższych hipotez (badania istotności współczynnika konkordancji rang) Boyle i McCarthy [1997a] proponują następujące statystyki:

$$
\begin{aligned}
& \chi^{2}=T(N-1) R C_{T} \\
& \chi^{2}=2(N-1) R C_{b i n}
\end{aligned}
$$

gdzie: $T$ - liczba lat badania, $N$ - liczba regionów ${ }^{36}$.

\footnotetext{
${ }^{34}$ Por. Boyle, McCarthy [1997a, s. 259] lub Fiedor, Kociszewski [2010, s. 189].

35 Należy zauważyć, że współczynnik konkordancji rang nawiązuje do koncepcji sigmakonwergencji, kiedy to współczynnik zmienności w kolejnych latach jest dzielony przez współczynnik zmienności w roku początkowym.

${ }^{36}$ Ponieważ statystyka testowa dla współczynnika w postaci binarnej jest znacznie niższa niż w postaci obejmującej wszystkie lata analizy, to (przy tych samych wartościach krytycznych) znacznie łatwiej jest odrzucić hipotezę o konwergencji za pomocą testu wykorzystującego 2.3.1.4 niż 2.3.1.3. Boyle i McCarthy [1997a, s. 260] wykazali się również pewną niekonsekwencją, bowiem we wzorze (2.3.1.1) numeracja zaczyna się od $t=0$, co oznacza, że liczba obserwacji (lat
} 
Statystyki powyższe, przy założeniu prawdziwości hipotezy zerowej, mówiącej o braku powiązania pomiędzy uporządkowaniem obszarów w poszczególnych latach - występowaniu konwergencji, mają rozkład $\chi^{2}$ o $(N-1)$ stopniach swobody.

Do powyższego sposobu wnioskowania o konwergencji można wysunąć pewne zastrzeżenia, szczególnie ważne w wypadku małych prób. W przypadku badania polskich województw $(N=16)$ i przyjmowanego, zazwyczaj w badaniach ekonomicznych, poziomu istotności rzędu 0,01, 0,05 lub 0,1, wartość krytyczna rozkładu $\chi^{2}$ wynosi odpowiednio 30,$6 ; 25,0 ; 22,3$. Przy całkowitym braku zmiany uporządkowania województw (a więc i braku gamma-konwergencji), tzn. gdy współczynnik konkordancji rang $R C_{\text {bin }}$ jest równy 1 , wartość statystyki (2.3.1.4) wynosi $\chi^{2}=2(N-1) R C_{b i n}=2 * 15 * 1=30$. Wartość ta jest mniejsza od wartości krytycznej przy minimalnym (z powyżej uwzględnionych) $1 \%$ poziomie istotności i nie pozwala na odrzucenie hipotezy zerowej o występowaniu konwergencji. Jest to oczywista sprzeczność: z jednej strony otrzymano wartość współczynnika konkordancji rang świadczącą o całkowitym braku zmian w uporządkowaniu województw - a więc o braku konwergencji, z drugiej zaś strony test istotności stwierdza coś przeciwnego: nie pozwala na odrzucenie hipotezy zerowej mówiącej o występowaniu konwergencji ${ }^{37}$. Co ciekawe liczebność polskich województw stanowi punkt krytyczny takiej inferencji, bowiem dla $N>16$, opisany dylemat już nie zachodzi (dla $N=17$, statystyka 2.3.1.4, przy maksymalnej wartości współczynnika konkordancji rang, wynosi $2 * 16 * 1=32$, a wartość krytyczna wynosi $\chi_{0,01 ; 16}^{2}=31,999$ i jest (minimalnie) mniejsza od wartości statystyki testu, co pozwala na podjęcie właściwej decyzji: odrzucenie hipotezy zerowej mówiącej o występowaniu gamma-konwergencji).

W przypadku współczynnika konkordancji rang danego wzorem (2.3.1.1) i statystyki (2.3.1.3) dla danych wojewódzkich i lat analizy 1995-2010 (czyli gdy $N=16$, a $T=16$ ) może wystąpić odwrotny, do opisanego powyżej, problem (błędnego wnioskowania o braku konwergencji). Otóż konstrukcja statystyki (2.3.1.3) powoduje, że nawet dla bardzo małych wartości współczynnika konkordancji rang (które powinny świadczyć o braku zgodności uporządkowańczyli gamma-konwergencji) wartość statystyki (2.3.1.3) jest na tyle duża, że nie pozwala stwierdzić o występowaniu badanego typu konwergencji. Na przykład dla $R C_{T}=0,2$ wartość statystyki (2.3.1.3) wynosić będzie $15 * 16 * 0,2=48$, a więc

badania) jest określona przez $T$-1, tymczasem we wzorach (2.3.1.3)-(2.3.1.4) $T$ określono jako liczbę lat badania.

${ }^{37}$ Należy podkreślić, że zarysowany problem nie występuje już przy wyższych $(5 \%, 10 \%)$ poziomach istotności, bowiem wówczas wartość statystyki testowej jest większa od wartości krytycznych, co pozwala na odrzucenie hipotezy zerowej i podjęcie właściwej decyzji o braku gamma-konwergencji. 
więcej niż jakakolwiek wartość krytyczna, co prowadzi do odrzucenia hipotezy zerowej, która w przypadku tak niskiej konkordancji rang jak $R C_{t}=0,2$ może być prawdziwa (por. p. 2 w p.2.3.2).

Ostatecznie stosowanie podejścia Boyle'a i McCarthy [1997a] do badań gamma-konwergencji dla próby polskich województw może prowadzić zarówno do popełnienia błędu pierwszego, jak i drugiego rodzaju, dlatego na użytek badań gamma-konwergencji w tej książce poniżej zaproponowano inne podejścia weryfikacji występowania tego zjawiska.

\subsubsection{Weryfikacja hipotezy o gamma-konwergencji za pomocą mo- dyfikacji testów Boyle'a-McCarthy'ego}

Na użytek badań w niniejszej książce rozszerzono zestaw stosowanych testów gamma-konwergencji o trzy następujące modyfikacje testów:

1) zastosowanie, w charakterze testu wstępnego, funkcji trendu kolejnych współczynników konkordancji rang. W przypadku, gdy można stwierdzić, że kolejne współczynniki wykazują istotną statystycznie, malejącą, tendencję można przejść do innych testów weryfikujących istotność ostatniej (lub innej, wybranej) statystyki mierzącej zmianę uporządkowania; w przeciwnym wypadku (braku istotnej statystycznie malejącej tendencji we współczynnikach konkordancji rang $R C_{t}$ ) można stwierdzić brak gamma-konwergencji;

2) zmianę statystyk testowych (2.3.1.3) - (2.3.1.4) na inną, której konstrukcja pozbawiona jest mankamentów, o których pisano pod koniec rozdziału 2.3.1;

3) zastosowanie innej miary (niż konkordancja rang $R C_{t}$ ) liczącej zmianę uporządkowania obszarów, np. współczynnik korelacji rang Spearmana wraz z zastosowaniem odpowiednich testów istotności.

Ad 1) Współczynnik zgodności rang postaci (2.3.1.2) obliczany jest w skrajnych latach analizy, a (2.3.1.1) dla wszystkich lat analizowanego okresu. Można jednakże wyliczać współczynniki konkordancji w dowolnym okresie analizy, w szczególności we wszystkich kolejnych, następujących po $t=0$, latach: $t=1, \ldots, T$ (gdzie $T$ jest interwałem pomiędzy pierwszym i ostatnim rokiem badania, a liczba obserwacji wynosi $T+1)$. Wykorzystując wzór:

$$
R C_{t}=\frac{\operatorname{wariancja}\left(\sum_{t=0}^{T} A R(Y)_{i t}\right)}{\operatorname{wariancja}\left((T+1) \times A R(Y)_{i 0}\right)}
$$

dla dwóch okresów analizy $(t=0,1)$ obliczony zostanie jeden współczynnik o wartości: 


$$
R C_{1}=\frac{\operatorname{wariancja}\left(\sum_{t=0}^{1} A R(Y)_{i t}\right)}{\text { wariancja }\left(2 \times A R(Y)_{i 0}\right)}
$$

Dla trzech okresów analizy $(t=0,1,2)$ zostaną obliczone dwa współczynniki: pierwszy o formule (2.3.2.1a), a drugi o formule:

$$
R C_{2}=\frac{\operatorname{wariancja}\left(\sum_{t=0}^{2} A R(Y)_{i t}\right)}{\text { wariancja }\left(3 \times A R(Y)_{i 0}\right)}
$$

Obliczając kolejne $R C_{t}$ dla $t=1, . ., T$ otrzymuje się szereg współczynników konkordancji rang:

$$
R C_{1}, R C_{2}, \ldots, R C_{T}
$$

Sednem proponowanej procedury jest sformułowanie dla szeregu współczynników (2.3.2.2) modelu trendu postaci:

$$
R C_{t}=\alpha_{0}+\alpha_{1} t+\xi_{t}
$$

Jeśli estymator parametru $\alpha_{1}$ jest nieistotny statystycznie (brak jest znaczącej tendencji malejącej w kolejnych $R C_{t}$ ) to oznacza, że brak jest również istotnych zmian w pozycjach analizowanych zmiennych w rankingu badanych obszarów w kolejnych latach analizy - brak jest gamma-konwergencji ${ }^{38}$. W przeciwnym wypadku, tzn. gdy współczynnik $\alpha_{1}$ jest ujemny i istotny statystycznie nie należy wykluczać tego rodzaju konwergencji i wykonać dodatkowe testy (na przykład zaproponowane w punkcie 2 i 3 poniżej) na jej potwierdzenie ${ }^{39}$.

Ad 2) Zamiast stosowania statystyk (2.3.1.3)-(2.3.1.4) można zaproponować zastosowanie statystyki (2.3.2.6), gdzie zamiast $r_{s}$ należy wstawić $R C_{T}\left(R C_{b i n}\right)$,

\footnotetext{
${ }^{38}$ Ujemna wartość estymatora $\alpha_{1}$ jest właściwie przesądzona, bowiem kolejne współczynniki $R C_{t}$ będą najprawdopodobniej uszeregowane malejąco - bowiem im dłuższy czas upływa od okresu początkowego, tym większe prawdopodobieństwo zmiany uporządkowania. Dlatego ważne jest spełnienie jednocześnie obu warunków: ujemności i statystycznej istotności estymatora $\alpha_{1}$.

${ }^{39}$ Początkowym zamiarem było zaproponowanie jeszcze jednej modyfikacji podobnej do powyższej, lecz wykorzystującej współczynnik korelacji rang Spearmana $r_{s}$. Otóż można, podobnie do (2.3.2.3) policzyć wartości współczynnika rang Spearmana $r_{s}$ dla kolejnych okresów analizy $\left(r_{S 1}\right.$, $\left.r_{S 2}, \ldots, r_{S T}\right)$, zbudować dla nich model trendu $\left(r_{s t}=\alpha_{0}+\alpha_{1} t+\xi_{t}\right)$, a badanie istotności $\alpha_{1}$ traktować, podobnie do trendu w kolejnych współczynnikach konkordancji rang Kendalla, jako test wstępny badania gamma-konwergencji. Lecz z doświadczeń autorki wynika, że kolejne $r_{s t}$ zawsze (w przeprowadzanych badaniach) wykazywały istotną statystycznie malejącą tendencję (w przeciwieństwie do konkordancji rang Kendalla), zatem test taki w żaden sposób nie „filtrował” wstępnie wyników.

${ }^{40}$ Które, jak już wspomniano, mogą, w przypadku próby 16 województw, prowadzić do popełnienia błędu I lub II rodzaju.
} 
lub użycie uproszczonego testu, w którym sprawdza się, czy konkordancja rang w pierwszym i ostatnim roku badania jest mniejsza od 0,25 :

$$
R C_{\text {bin }}<0,25
$$

Jeśli warunek (2.3.2.4) jest spełniony należy spodziewać się, że występuje gamma-konwergencja. Wartość 0,25 wynika z badań symulacyjnych, które pokazały, że w punkcie wyrównania się poziomów wszystkich zmiennych (osiągnięcia konwergencji), tzn. gdy ranga (pozycja) wszystkich obszarów jest taka sama, wówczas, bez względu na początkowe uporządkowanie obszarów, wartość $R C_{b i n}$ (danego wzorem 2.3.1.2) jest równa 0,25. Jeśli zatem $R C_{b i n}<0,25$ należy spodziewać się, że punkt ten został przekroczony. Oznacza to, że obszary początkowo biedniejsze wykazały tak wysokie tempa wzrostu, że nie tylko dogonily (co ma miejsce dla $R C_{b i n}=0,25$ ) lecz przegonily obszary początkowo bogatsze, czego konsekwencją jest zmiana uporządkowania obszarów - leapfrogging (co Sala-i-Martin [1996, s. 1329] określił również jako overshooting).

Ad 3) Jeśli liczenie konkordancji rang jest $\mathrm{z}$ jakiegoś powodu utrudnione lub niemożliwe, można rozważyć użycie innej miary zależności rang - współczynnik korelacji rang Spearmana ${ }^{41}$ :

$$
r_{S}=1-\frac{6 \sum_{i=1}^{n} d_{i}^{2}}{N^{3}-N}
$$

gdzie: $d_{i}-$ dystans (różnica) pomiędzy rangami, która oznacza w badaniach konwergencji dystans pomiędzy rangami cechy w dwóch różnych (skrajnych) okresach analizy (np. dystans pomiędzy rangą PKB per capita dla poszczególnych województw pomiędzy rokiem 1995 i 2010), $N$ - liczebność próby.

Zgodnie z klasyczną interpretacją współczynnika rang Spearmana, jego poszczególne wartości oznaczają:

- pełną zgodność uporządkowań, gdy korelacja rang jest doskonała, tzn. $r_{S}=1$,

- pełną przeciwstawność (niezgodność) uporządkowań, gdy korelacja rang jest przeciwna: $r_{S}=-1$,

- brak zgodności (losowość) uporządkowań, gdy $r_{S}=0$.

Znak otrzymanego współczynnika informuje zatem o tym, czy doszło do zmiany uporządkowania badanych regionów (gamma-konwergencji). Potwierdza to ujemna wartość $r_{s}$. Lecz nie tylko ujemna, bowiem również zerowa wartość współczynnika (2.3.2.5), którą standardowo interpretuje się jako brak zgodności rang, w przypadku badań konwergencji oznacza, że początkowe uporządkowa-

\footnotetext{
${ }^{41}$ Należy zauważyć, że współczynnik rang Spearmana w postaci (2.3.2.5) zakłada brak rang wiązanych. Jeśli założenie to ma być uchylone, należy zastosować właściwą formułę korelacji rang dla przypadku rang wiązanych.
} 
nie regionów pod względem danej cechy jest inne - losowe - w stosunku do uporządkowania w końcowym okresie badania. Wydaje się, że jest to warunek wystarczający, aby stwierdzić, że uporządkowanie regionów istotnie się zmieniło (występuje gamma-konwergencja). A zatem dla $r_{\mathrm{s}}>0$ (w celu stwierdzenia, czy $r_{s}$ nieistotnie różni się do 0) można zastosować statystykę postaci ${ }^{42}$ :

$$
t_{r_{s}}=\frac{r_{s} \sqrt{N-2}}{\sqrt{1-r_{s}^{2}}}
$$

pozwalającą na zweryfikowanie następującego zespółu hipotez:

$H_{0}: r_{\mathrm{s}}=0$ (występuje gamma-konwergencja),

$H_{1}: r_{\mathrm{s}}>0$ (brak gamma-konwergencji).

Jeśli wartości statystyki (2.3.2.6) są niemniejsze od wartości krytycznych (odczytanych z rozkładu $t$-Studenta) należy odrzucić hipotezę zerową i stwierdzić brak gamma-konwergencji. W przeciwnym przypadku (gdy wartość 2.3.2.6 jest mniejsza od wartości krytycznych) nie ma podstaw do odrzucenia hipotezy zerowej (ponieważ początkowe uporządkowanie regionów jest losowe w stosunku do końcowego uporządkowania - występuje gamma-konwergencja).

\subsection{Konwergencja stochastyczna}

Koniec lat osiemdziesiątych i początek lat dziewięćdziesiątych, to okres opracowywania metod służących weryfikacji hipotezy o występowaniu konwergencji na podstawie szeregów czasowych. Ten rodzaj konwergencji zakłada ewolucję rozkładu badanej cechy w czasie. Mając na uwadze stochastyczny charakter szoków związanych z różnymi zmiennymi ekonomicznymi, przyjmuje się, że częstość i siła tych szoków mają większy wpływ na państwa zacofane niż rozwinięte i powodują w efekcie większe rozproszenie badanej cechy (zob. Fiedor, Kociszewski [2010, s. 189]). Podkreśla się również, że tradycyjne metody badania konwergencji nie mogą być stosowane do szeregów niestacjonarnych, bowiem występuje wówczas prawdopodobieństwo regresji pozornej (otrzymania pozornie istotnych powiązań zmiennych). Jedną z metod pomiaru w obszarze koncepcji stochastycznej konwergencji jest podejście oparte o kointegrację szeregów czasowych. Skointegrowanie dowodzi, iż szeregi dążą do stanu równowagi w długim okresie, zaś odchylenia od długookresowej ścieżki są stacjonarne. Jeśli zatem zmienne charakteryzowane za pomocą szeregów danych pochodzących z różnych lokalizacji (regionów, krajów) są skointegrowa-

\footnotetext{
${ }^{42}$ Wykorzystano test istotności współczynnika autokorelacji $i$-tego rzędu (przyjęto, że $i=0$ ) podany w Strahl [2002, s.190]. Pominięto liczenie wartości bezwzględnej z $r_{s}$, bowiem test poleca się przeprowadzać jedynie dla dodatnich wartości współczynnika korelacji (dla wartości ujemnych $r_{s}$ można bez dodatkowych testów stwierdzić gamma-konwergencję).
} 
ne, to mówimy, że pomiędzy badanymi regionami zachodzi konwergencja stochastyczna.

\subsubsection{Kointegracja pomiędzy dwoma regionami. Podejście Engle’a i Grangera}

Jeśli istnieje długookresowy związek pomiędzy dwiema (lub więcej) niestacjonarnymi zmiennymi, to odchylenia od tej długookresowej ścieżki powinny być stacjonarne $^{43}$, a zmienne są skointegrowane. Matematyczny zapis tej zależności przypisuje się laureatom Nagrody Nobla z 2003 r. - R. Engle'owi (nagrodzonemu za metody analizy ekonomicznych szeregów czasowych ze zmienną w czasie wariancją - model ARCH) i sir C. Grangerowi (za metody analizy ekonomicznych szeregów czasowych ze wspólnymi trendami - kointegrację), którzy sformułowali definicję kointegracji dwóch zmiennych ${ }^{44}$. Uogólnieniem tej definicji na przypadek $N$ zmiennych (reprezentujących, w przypadku badań konwergencji, $N$ obszarów) jest następujące twierdzenie:

Jeśli $\mathbf{X}_{t}$ oznacza $N \mathrm{x} 1$ wektor zmiennych $x_{1 t}, x_{2 t}, \ldots, x_{N t}$ oraz:

a) każda z nich jest integrowana rzędu $d$, co zapisuje się jako $I(d)^{45}$,

b) istnieje $N x 1$ wektor $\boldsymbol{\beta}$ taki, że $\mathbf{X}_{t}^{\prime} \boldsymbol{\beta} \sim I\left(\begin{array}{ll}d & b\end{array}\right)$,

to: $\mathbf{X}_{t}^{\prime} \boldsymbol{\beta} \sim C I(d, b)$, a wektor $\boldsymbol{\beta}$ nazywamy wektorem kointegracyjnym ${ }^{46}$.

Współczynniki $\boldsymbol{\beta}$ wyznaczają parametry długookresowej równowagi pomiędzy zmiennymi wchodzącymi w skład wektora $\mathbf{X}$, co w przypadku badań konwergencji oznacza długookresową równowagę pomiędzy badanymi $N$ obszarami pod względem analizowanej cechy.

Popularnym niegdyś algorytmem badającym skointegrowanie zmiennych był test Engle'a-Grangera (por. Engle, Granger [1987, ss. 251-256]). W procedurze tej w pierwszym kroku bada się rząd integracji zmiennych, a następnie estymuje związek długookresowej równowagi postaci:

$$
x_{1 t}=\beta_{0}+\beta_{1} x_{2 t}+\xi_{t}
$$

\footnotetext{
${ }^{43}$ Niestacjonarność w tym wypadku oznacza, że zmienne są integrowane rzędu pierwszego. Więcej o niestacjonarności zmiennych, jej rodzajach i metodach weryfikacji można przeczytać np. u Kusideł [2000, ss. 17-23].

${ }^{44}$ Por. Engle, Granger [1987].

${ }^{45} \mathrm{~W}$ ekonometrii empirycznej najczęstszym przypadkiem jest sytuacja, gdy badane szeregi $x_{t}$ są integrowane rzędu pierwszego, tzn. $d=1$, rzadziej $d=2$.

${ }^{46} \mathrm{~W}$ literaturze funkcjonuje zarówno pojęcie wektor kointegracyjny, jak i kointegrujący. Autorka używa jednakże pierwszego, chcąc zachować spójność z poprzednimi swoimi pracami. Jednocześnie nie wydaje się, aby takie nazewnictwo było mylące - oba określenia oznaczają to samo (co potwierdza autor bardzo wyczerpującej pozycji o analizie kointegracyjnej pt. Wielowymiarowa analiza kointegracyjna w ekonomii - M. Majsterek).
} 
Reszty z powyższego równania są odchyleniami od długookresowej równowagi. Jeśli odchylenia te są stacjonarne, to zmienne $x_{1 t}, x_{2 t} \sim C I(1,1)$, a wektor kointegracyjny ma postać $\left[\begin{array}{lll}1 & -\beta_{0} & -\beta_{1}\end{array}\right]$. Powyższe równanie może być przydatne do testowania kointegracji pomiędzy dwoma obszarami, np. PKB per capita dwóch krajów (regionów), czy w szczególności danym obszarem a obszarem referencyjnym (np. PKB per capita Polski w stosunku do PKB per capita UE 27).

Metoda Engle'a i Grangera jest dość prostym narzędziem testowania kointegracji, lecz tylko w przypadku dwóch analizowanych zmiennych związek długookresowej równowagi można wyznaczyć jednoznacznie (lub stwierdzić, że zmienne nie są skointegrowane). Jeśli rośnie liczba regresorów w (2.4.1.1) rośnie liczba możliwych związków kointegracyjnych. W przypadku większej liczby zmiennych pojawia się również dylemat, która z nich wystąpi w roli zmiennej objaśnianej, co jest szczególnie trudne do rozstrzygnięcia w badaniach konwergencji. Wówczas bowiem poszczególne zmienne charakteryzują różne regiony i kraje - a wskazanie, które $\mathrm{z}$ nich wybrać jako zmienną objaśnianą (wówczas pozostałe są objaśniającymi) - nie jest łatwe, a czasami wręcz niemożliwe do rozstrzygnięcia. Tego rodzaju dylematów pozbawiona jest, opisana poniżej, procedura Johansena służąca do badania kointegracji (konwergencji stochastycznej) wielu zmiennych.

\subsubsection{Kointegracja pomiędzy więcej niż dwoma regionami. Podejście Johansena}

Metoda Engle'a i Grangera (opisana w powyższym punkcie) jest prostym narzędziem testowania kointegracji, lecz ze względu na swoje ograniczenia, coraz rzadziej stosowanym. W jej miejsce stosuje się procedurę opracowaną przez S. Johansena [1988, s. 231-254], wykorzystującą tzw. VECM-y (Vector Error Correction Model) postaci:

$$
\Delta \mathbf{X}_{t}=\boldsymbol{\Psi}_{0} \mathbf{D}_{t}+\boldsymbol{\Pi} \mathbf{X}_{t-1}+\sum_{i=1}^{k-1} \Pi_{i} \Delta \mathbf{X}_{t-i}+\mathbf{e}_{t}
$$

$\mathbf{X}_{t}$ - wektor obserwacji na bieżących wartościach $N$ zmiennych modelu: $\mathbf{X}_{t}=\left[\begin{array}{llll}x_{1 t} & x_{2 t} \ldots & x_{N t}\end{array}\right]$,

$\mathbf{D}_{t}$ - wektor deterministycznych składników równań, takich jak wyraz wolny, zmienna czasowa, zmienne zero-jedynkowe lub inne niestochastyczne regresory,

$\boldsymbol{\Psi}_{0}-$ macierz parametrów przy zmiennych wektora $\mathbf{D}_{t}$, nie zawierająca zerowych elementów,

$\Pi-$ macierz parametrów przy zmiennych wektora $\mathbf{X}_{t}$,

$\mathbf{e}_{t}-$ wektory stacjonarnych zakłóceń losowych: $\mathbf{e}_{t}=\left[\begin{array}{lll}e_{1 t} & e_{2 t} \ldots & e_{N t}\end{array}\right]$. 
Kluczowym parametrem w badaniach konwergencji stochastycznej jest rząd macierzy $\Pi$, który jest równy liczbie niezależnych wektorów kointegracyjnych. Jeśli rząd $\Pi$ wynosi 0 , to nie występuje kointegracja zmiennych, co oznacza jednocześnie brak konwergencji stochastycznej. Jeśli macierz $\Pi$ jest rzędu pierwszego, istnieje tylko jeden wektor kointegracyjny a wyrażenie $\Pi \mathbf{\Pi} \mathbf{X}_{t} \mathrm{w}$ (2.4.2.1) jest czynnikiem korekty błędu (error correction term). Jeśli macierz $\Pi$ jest pełnego rzędu $(N)$, wtedy szeregi wektora $\mathbf{X}_{t}$ są stacjonarne i model (2.4.2.1) może być zapisany $\mathrm{w}$ postaci modelem VAR (vector autoregressive model) dla poziomów zmiennych (por. Kusidel [2000]).

W niniejszej pracy modele VECM wykorzystywane są nie tylko do wyznaczania liczby wektorów kointegracyjnych na podstawie których istnienia wnioskuje się o konwergencji. Wykorzystano je również do wyznaczenia elastyczności produkcji względem kapitału (w podrozdziale 3.1.2), która jest kluczowym parametrem w szacunkach regionalnego TFP. Taki sposób wyznaczania tego parametru jako jedyny, wg niektórych autorów (np. Gradziwicz, Kolasa [2004]), gwarantuje otrzymanie zgodnych i nieobciążonych jego szacunków w przypadku niestacjonarności zmiennych.

Innym jeszcze zastosowaniem VECM na który można wskazać w kontekście badań w tej książce jest wykorzystanie ich w ewaluacji polityki spójności. Jedną z metod oceny wpływu programów unijnych jest metoda polegająca na wyliczeniu efektu, który te programy mogą wywoływać. Efekt ten liczy się najczęściej jako różnicę pomiędzy wartością badanego wskaźnika (np. PKB per capita) w symulacji ,bez funduszy” i ,z funduszami”, do czego używa się dużych, skomplikowanych i drogich modeli makroekonomicznych. $\mathrm{Z}$ drugiej strony, w niektórych badaniach wylicza się tzw. efekt brutto, który jest różnicą w wartości wskaźników wynikającą z funkcji trendu dla danych zawierających efekt działania programu i funkcji trendu dla danych wcześniejszych (sprzed realizacji programu lub polityki) - podejście takie opisane zostało za pomocą wzoru (5.1.1). O ile wykorzystanie modeli makroekonomicznych nie zawsze jest możliwe (ich poziom skomplikowania wykracza poza ramy standardowego badania ewaluacyjnego), to druga metoda polegająca na prostych, jednorównaniowych modelach trendu (w których badana zmienna jest funkcją, najczęściej liniową, czasu) wydaje się znów nazbyt upraszczające. Tymczasem bardziej zaawansowanym narzędziem do ekstrapolacji badanych wskaźników mogą być właśnie modele VECM (lub $\mathrm{VAR}^{47}$ ), które mogą stanowić pomost pomiędzy dwoma wcześniej wspomnianymi metodami wyznaczania efektu wpływu funduszy. Modele te pozwalają na bardziej precyzyjne prognozy bowiem, w przeciwieństwie do prostej ekstrapolacji trendu, uwzględniają wpływ innych

${ }^{47}$ Użycie tych modeli w takim celu zostało wykorzystane przez autorkę w pracy Drążkiewicz i in. [2007]. 
zmiennych ujętych w systemie równań (2.4.2.1). Mają jednocześnie tę przewagę nad innymi modelami służącymi do prognozowania, że nie trzeba w nich dokonywać założeń co do kształtowania się zmiennych objaśniających w prognozowanym okresie (które w przypadku ewaluacji musiałyby zawierać w sobie wpływ ewaluowanej polityki, której wartość właśnie należy wyliczyć przy zastosowaniu prezentowanej metodologii).

\subsubsection{Postacie modeli VECM i ich wpływ na wnioskowanie o kointegracji}

W procedurze Engle'a i Grangera (opisanej w p. 2.4.1) włączenie do równania zmiennej czasowej, wyrazu wolnego lub innych deterministycznych regresorów, jest jednoznaczne $\mathrm{z}$ pojawieniem się reprezentacji tych zmiennych $\mathrm{w}$ wektorze kointegracyjnym. W przypadku procedury Johansena (opisanej w $\mathrm{p}$. 2.4.2), elementy wektora $\mathbf{D}_{t} \mathrm{w}(2.4 .2 .1)$ nie mają swojej reprezentacji w wektorze lub wektorach kointegracyjnych. Generalnie szacowanie modelu postaci (2.4.2.1) z tzw. nieograniczonym wyrazem wolnym, powoduje wygenerowanie liniowego trendu w poziomach zmiennych wektora $\mathbf{X}_{t}$ (lecz nie w wektorze kointegracyjnym). Można także włączyć wyraz wolny do wektora kointegracyjnego (model z ograniczonym wyrazem wolnym), co spowoduje, że poziomy zmiennych nie wykazują trendu liniowego. Dodatkowo, jeśli w modelu (2.4.2.1) uwzględniono trend liniowy, tzn. gdy $\mathbf{D}_{t}=[1 t]$, to spowoduje to wygenerowanie kwadratowego trendu w procesach generujących zmienne wektora $\boldsymbol{X}_{t}$. Relacja długookresowa $\boldsymbol{\beta} \mathbf{X}_{t}$, będzie natomiast charakteryzowała się trendem liniowym. Można, podobnie jak w przypadku wyrazu wolnego, spowodować, że reprezentacja zmiennej $t$ pojawi się w wektorze kointegracyjnym (model z ograniczonym trendem). Takie postępowanie powoduje, że trend liniowy będzie obecny w relacji kointegracyjnej (taką wersję modelu zastosowano do wyznaczenia elastyczności produkcji względem kapitału w regionach, co umożliwiło oszacowanie efektów postępu technologicznego - por. tabela 3.1.2.2). Ponieważ sposób uwzględnienia wyrazu wolnego i/lub trendu ma wpływ na wnioski dotyczące kointegracji, a więc i konwergencji zmiennych, należy prawidłowo wyspecyfikować VECM, przed przystąpieniem do testowania liczby wektorów kointegracyjnych (por. S. Johansen, 1995, s. 82) ${ }^{48}$.

$\mathrm{W}$ celu przetestowania hipotezy zerowej o obecności wyrazu wolnego lub trendu liniowego w wektorze kointegracyjnym przeciwko hipotezie alternatywnej o nieograniczonym modelu VECM należy estymować obie wersje modelu. Oznaczyć uporządkowane malejąco pierwiastki charakterystyczne nieograniczonej

\footnotetext{
${ }^{48} \mathrm{Na}$ temat konsekwencji i sposobów uwzględniania wyrazu wolnego oraz trendu w VECM można przeczytać u Kusideł [2000, rozdział 3.2], gdzie podano testy statystyczne umożliwiające wybór odpowiedniego modelu.
} 
macierzy $\Pi$ jako $\lambda_{1}, \lambda_{2}, \ldots, \lambda_{N}$, a pierwiastki ograniczonej macierzy $\Pi$ jako $\lambda_{1}^{*}, \lambda_{2}^{*}, \ldots, \lambda_{N}^{*}$. Jeśli nieograniczona forma modelu posiada $r$ niezerowych pierwiastków charakterystycznych, to statystyka ilorazu wiarygodności:

$$
L R=-T \sum_{i=r+1}^{N}\left[\ln \left(1-\lambda_{i}^{*}\right)-\ln \left(1-\lambda_{i}\right)\right]
$$

ma asymptotyczny rozkład $\chi^{2} \mathrm{z}(N-r)$ stopniami swobody.

Jeśli wartości (2.4.3.1) są mniejsze od wartości krytycznych to nie ma podstaw do odrzucenia hipotezy zerowej dotyczącej danego ograniczenia (włączenia wyrazu wolnego lub zmiennej czasowej do relacji kointegracyjnej). Wartości (2.4.3.1) większe od wartości krytycznej powodują odrzucenie hipotezy zerowej na korzyść alternatywnej mówiącej o nieograniczonej postaci macierzy $\Pi$ (jak we wzorze (2.4.2.1).

\subsubsection{Testowanie liczby wektorów kointegracyjnych - rzędu kointe- gracji}

W badaniu rzędu macierzy $\Pi$ w modelu (2.4.2.1) wykorzystuje się fakt, że rząd macierzy jest równy liczbie jej niezerowych pierwiastków charakterystycznych. Liczba różnych (liniowo niezależnych) wektorów kointegracyjnych może być zatem wyznaczana poprzez badanie pierwiastków charakterystycznych macierzy $\Pi$. Dla $N$ pierwiastków charakterystycznych (uporządkowanych tak, że $\lambda_{1}>\lambda_{2}>, \ldots, \lambda_{N}$ ), jeśli zmienne wchodzące w skład wektora $\mathbf{X}_{t}$ są nieskointegrowane, rząd macierzy $\Pi$ wynosi 0 i wszystkie pierwiastki charakterystyczne są równe zero. Jeśli rząd macierzy $\Pi$ wynosi 1 , to tylko jeden z pierwiastków charakterystycznych jest różny od zera, a dokładnie: $\lambda_{1}>0$, pozostałe zaś są zerowe. Ogólnie, jeśli rząd macierzy $\Pi$ wynosi $r$ to $r$ pierwszych pierwiastków charakterystycznych jest różnych od zera.

Do ustalania liczby niezerowych pierwiastków charakterystycznych - rzędu kointegracji można użyć następujących statystyk:

$$
\begin{gathered}
\lambda_{\text {trace }}(r)=-T \sum_{i=r+1}^{N} \ln \left(1-\lambda_{i}\right) \\
\lambda_{\max }(r, r+1)=-T \ln \left(1-\lambda_{r+1}\right)
\end{gathered}
$$

gdzie: $\lambda_{i}$ - oszacowane wartości pierwiastków charakterystycznych (wartości własne), $T$ - liczba dostępnych obserwacji, $N$ - liczba regionów.

Pierwsza statystyka służy do testowania hipotezy zerowej, że liczba różnych od siebie wektorów kointegracyjnych jest mniejsza lub równa $r$. Hipoteza alternatywna zakłada, że liczba ta jest większa od $r$.

Druga statystyka służy do testowania hipotezy zerowej, że liczba wektorów kointegracyjnych wynosi $r$ przeciwko hipotezie alternatywnej, że jest ich $r+1$. 
W przypadku, gdy obliczona wartość jednej z wymienionych statystyk jest mniejsza od wartości krytycznej (z rozkładu $\chi^{2} \mathrm{z}(N-r)$ stopniami swobody) nie ma podstaw do odrzucenia hipotezy zerowej. Wartości większe od wartości krytycznych pozwalają na odrzucenie hipotezy zerowej na korzyść alternatywnej - w tym ostatnim przypadku stwierdzenie kointegracji pozwala na wnioskowanie o występowaniu konwergencji stochastycznej wśród $N$ analizowanych obszarów (np. 16 województw Polski) pod względem badanej cechy (np. PKB per capita).

\subsection{Podsumowanie}

Hipoteza konwergencji gospodarczej została spopularyzowana w literaturze ekonomicznej wraz z neoklasyczną teorią wzrostu i modelem Solowa [1956]. Początkowo konwergencja rozumiana była jako zbliżanie się, wyrównywanie, narodowych dochodów per capita, co statystycznie weryfikowano poprzez pokazanie, że kraje o początkowo niższych wartościach PKB per capita charakteryzują się wyższym tempem wzrostu niż kraje o początkowo wyższych wartościach PKB pc. Proces ten nazywany jest w literaturze (por. np. Sala-i-Martin [1992]) efektem doganiania (catch-up effect) i opisywany jest najczęściej za pomocą modeli beta-konwergencji absolutnej (por. De Long [1988], Baumol [1986], Sala-i-Martin [1992], podrozdział 2.1).

Brak konwergencji absolutnej nie wyklucza występowania innego jej rodzaju: konwergencji warunkowej (por. Mankiw, Romer, Weil [1992], Barro, Sala-iMartin [1992]). O ile istotą zbieżności absolutnej jest fakt, iż wszystkie badane gospodarki dążą do tego samego, ustalonego stanu równowagi długookresowej $^{49}$, to istotą konwergencji warunkowej jest założenie, że poszczególne gospodarki mogą mieć własne stany równowagi długookresowej, uzależnione od pewnych stałych czynników dla nich charakterystycznych (takich jak postęp technologiczny, stopa inwestycji i zatrudnienia - które warunkuja wzrost gospodarczy).

Od końca lat 80. ubiegłego wieku, wraz z krytyką własności estymatorów modeli beta-konwergencji (dobitnie sformułowaną przez Quaha [1993] i Friedmana [1992]), coraz więcej mówiło się o pewnej antynomii polegającej na tym, że faktowi istnienia beta-konwergencji może towarzyszyć zwiększanie zróżnicowania rozkładu badanej zmiennej. Krytyka beta-konwergencji sprzyjała zdefiniowaniu i ugruntowaniu się innej jej koncepcji: sigma-konwergencji, oznaczającej zmniejszanie się dyspersji rozkładu badanej cechy w czasie, której poświęcono podrozdział 2.2 (w którym omówiono szerokie spektrum narzędzi do weryfikacji tego rodzaju konwergencji wraz z pewnymi modyfikacjami niektó-

${ }^{49}$ Por. Próchniak, Rapacki [2009, ss. 148-149]. 
rych testów - (2.2.2.3) i (2.2.3.2) - co jeszcze bardziej rozszerza, i tak już bogate, możliwości testowania sigma-konwergencji).

Odpierając zarzuty sformułowane przez Quaha [1993] i Friedmana [1992], Sala-i-Martin [1996] argumentował, że koncepcja sigma-konwergencji również nie jest pozbawiona wad, a w niektórych przypadkach w ogóle nie wnosi żadnych informacji; w cytowanym artykule Sala-i-Martin przywołał przykład rankingu drużyn NBA, dla których zróżnicowanie jest stałe w czasie - nie mają więc zastosowania testy sigma-konwergencji, podczas gdy testy beta-konwergencji pokażą, czy słabsze drużyny pną się w rankingach w górę, czy nie. Sala-i-Martin [1996, s. 1328] podkreślił, że obie koncepcje konwergencji mogą dostarczać interesujących wniosków, choć są ideologicznie inne: sigmakonwergencja bada jak rozkład cechy zmienia się w czasie a beta-konwergencja bada mobilność tej cechy wewnątrz rozkładu.

Powodem sprzeczności we wnioskach dla beta i sigma-konwergencji może być również zjawisko nazywane w literaturze przedmiotu leapfrogging - tak szybkiego rozwoju obszarów biedniejszych, że nie tylko występuje efekt doganiania, ale wręcz przeganiania - co tłumaczy zwiększenie nierówności wśród badanych obszarów. Do testowania tego efektu można użyć podejścia, zaprezentowanego przez Boyle'a i McCarthy'ego [1997a], nazywanego gamma-konwergencją. Jak jednak stwierdzono w podrozdziale 2.3.1, konstrukcja statystyk testowych zaproponowanych przez wspomnianych powyżej autorów, w przypadku próby 16 województw może prowadzić do popełnienia zarówno błędu pierwszego i drugiego rodzaju. Dlatego, na użytek badań w niniejszej książce, zaproponowano własne podejście do testowania gamma-konwergencji opisane w podrozdziale 2.3.2.

Ostatecznie, pomimo krytyki klasycznego podejścia beta-konwergencji można stwierdzić, że testy tego rodzaju powinny być punktem wyjścia wszystkich badań. Brak beta-konwergencji cenzuruje poszukiwania innych jej rodzajów. Występowanie beta-konwergencji powinno być natomiast asumptem do poszukiwania innych jej typów - sigma i gamma. W tym kontekście konwergencja stochastyczna, zakładająca ewolucję rozkładu badanej cechy w czasie oraz stochastyczny charakter szoków oddziałujących na zmienne ekonomiczne powinna być traktowana raczej jako komplementarne, niż substytucyjne narzędzie do wcześniej wymienionych. Wobec przedstawionych w tym rozdziale faktów, formalnością wydaje się odpowiedź na ostatnie z pytań sformułowanych w odniesieniu do pierwszego celu pracy, a mianowicie, że weryfikacja hipotezy o konwergencji za pomocą różnych metod jej pomiaru może prowadzić do przeciwnych wniosków. 


\section{ROZDZIAL 3 \\ KONWERGENCJA GOSPODARCZA W POLSCE}

Celem niniejszego rozdziału jest przeprowadzenie badań pozwalających na zrealizowanie drugiego głównego celu rozprawy: ocenę, czy zachodzi proces szeroko pojętej konwergencji gospodarczej wśród polskich województw ${ }^{1}$. Pod nazwą „szeroko pojętej konwergencji” należy rozumieć szeroki zakres badanych zmiennych, który zawiera nie tylko najpopularniejszy wskaźnik PKB per capita, lecz również wydajność pracy oraz łączną produktywność czynników produkcji zarówno w ujęciu zagregowanym jak i w podziale na sektory gospodarcze. Szerokie ujęcie tematu dotyczy również zestawu zastosowanych narzędzi: beta-, sigma-, gamma-konwergencji, konwergencji stochastycznej oraz konwergencji do stanów równowagi.

$\mathrm{W}$ podrozdziale 3.1 zdefiniowano zmienne (indykatory aktywności gospodarczej) będące przedmiotem badań konwergencji w tej książce. Ze względu na ścisły związek konwergencji ze wzrostem gospodarczym, szeroko wykorzystywanym $w$ badaniach miernikiem jest PKB per capita (PKB pc.). Niektórzy autorzy (Le Gallo, Dall'erba [2007]) polecają stosowanie wydajności pracy, a nie PKB pc, jako podstawowego miernika w badaniach konwergencji gospodarczej. Aby nie rozstrzygać, który z tych wskaźników gospodarczych jest lepszy, badania $\mathrm{w}$ oparciu o PKB pc. są prowadzone równolegle $\mathrm{z}$ badaniami wydajności pracy (w podrozdziale 3.2). Wobec polemiki pomiędzy zwolennikami neoklasycznego i endogenicznego modelu wzrostu i wynikającego z niej sporu, co do roli i źródeł postępu technologicznego we wzroście gospodarczym, zbadano również konwergencję TFP (w podrozdziale 3.3). W rozdziale 3.4 zbadano zaś konwergencję w podziale na 4 sektory gospodarki.

Najważniejsze wnioski $\mathrm{z}$ przeprowadzonych badań umieszczono w podsumowaniu.

\footnotetext{
${ }^{1}$ Województwa są nazywane w dalszej części pracy również regionami (jak już wcześniej wspominano pod nazwą region rozumie się w tej pracy jednostki statystyczne NUTS 2).
} 


\subsection{Dane statystyczne, metodologia pomiaru zmiennych i problemy z tym związane}

\subsubsection{PKB per capita i wydajności pracy}

Dane o PKB per capita wyliczone zostały jako iloraz wartości Produktu Krajowego Brutto i liczby mieszkańców Polski (ludność faktycznie zamieszkała w dn. 30.VI). Dane te są zgodne z wartościami publikowanymi przez GUS. Jeśli chodzi o źródło danych statystycznych o wydajności (produktywności) pracy, to nie wykorzystano w tym celu szacunków GUS, lecz policzono iloraz wartości dodanej brutto (WDB) i liczby pracujących wg BAEL. Tak policzona wydajność pracy nieznacznie różni się od wartości monitorowanej przez GUS (por. rachunki regionalne w BDL), który do przeliczeń używa innej liczby pracujących - która jest skorygowaną wartością pochodzącą $\mathrm{z}$ rachunków narodowych $^{2}$. Na decyzję o wykorzystaniu własnych szacunków wydajności pracy wpłynął przede wszystkim fakt, że sposób ten pozwala na znaczne wydłużenie szeregów czasowych (GUS publikuje swoje szacunki od roku 2002) 3 $^{3}$.

W literaturze przedmiotu PKB per capita i wydajność pracy stanowią czasem alternatywne mierniki, na podstawie których wnioskuje się o konwergencji gospodarczej. Powstaje pytanie, czy zmienne te należy rzeczywiście stosować zamiennie, czy raczej komplementarnie? Różnice w dynamice PKB per capita i WDB na pracującego wynikają z innej dynamiki mianownika (licznik różni się o względnie stałą, w regionach i czasie, wartość), w szczególności od 2004 r., od kiedy to liczba pracujących rośnie, zaś spada liczba mieszkańców Polski. Zmiany w dynamice mianownika wskaźników PKB per capita i WDB na pracującego (WDB pp.) nie wpływają radykalnie na uszeregowanie województw pod względem analizowanych wskaźników - na poniższych mapach wyraźnie zaznacza się uboższa - wschodnia część Polski, oraz grupa najzamożniejszych województw, które tworzą województwa: mazowieckie, śląskie, dolnośląskie, wielkopolskie, zachodnio-pomorskie, pomorskie - por. mapy 3.1.1.1-3.1.1.4.

\footnotetext{
${ }^{2}$ Do przeliczeń wartości dodanej brutto na pracującego GUS używa przeciętnej liczby pracujących w gospodarce narodowej, którą zwiększa o pracujących w jednostkach sektora budżetowego, szarej strefie i działalności ubocznej. Ostatecznie liczba pracujących stosowana przez GUS do szacunków wartości dodanej brutto na 1 pracującego, bliższa jest, przyjętej w tej pracy, liczbie pracujących według BAEL niż pracujących w gospodarce narodowej.

${ }^{3}$ Pewne znaczenie miał również fakt, że dla danych BAEL dostępne były autorce dane o liczbie pracujących z wykształceniem wyższym (w szczególności w sektorach gospodarczych).
} 
Mapa 3.1.1.1. Rozkład* PKP per capita w 1995 r.

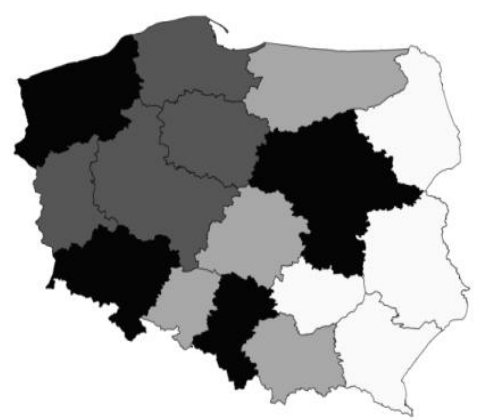

Mapa 3.1.1.3. Rozklad WDB na pracującego w 1995 r.

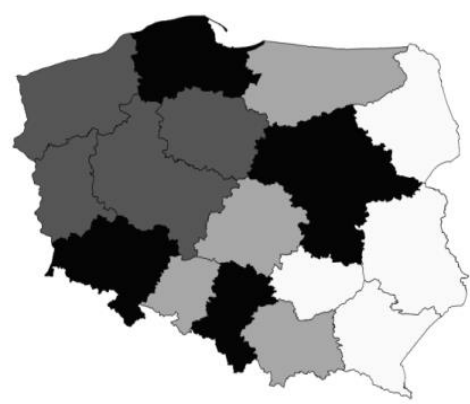

Mapa 3.1.1.2. Rozkład PKB per capita w 2010 r.

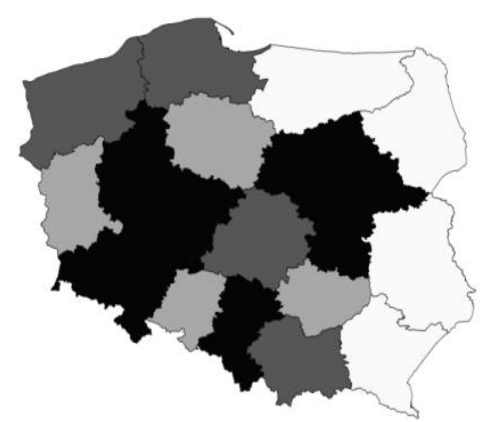

Mapa 3.1.1.4. Rozkład WDB na pracującego w 2010 r.

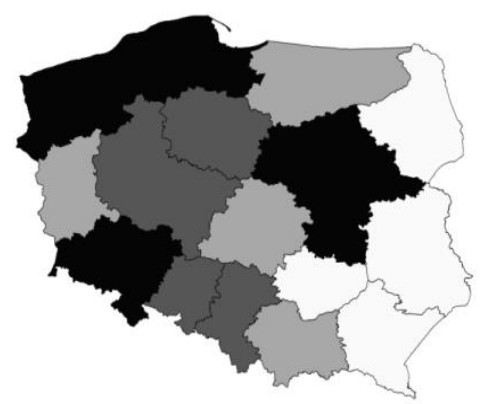

Źródło: opracowanie własne

*Im ciemniejsze (jaśniejsze) pole tym wyższy (niższy) kwartyl rozkładu

Z powyższych map wynika, że rozkład kwartylowy obu wskaźników w $1995 \mathrm{r}$. jest niemalże identyczny. Zmieniła się jedynie pozycja zachodniopomorskiego które w 1995 r., pod względem PKB per capita należało do pierwszej czwórki województw, do której, pod względem wydajności pracy, należało wówczas pomorskie. Różnice w 2010 r. są większe i dotyczą większości województw. Tylko dla sześciu (podlaskie, lubelskie, podkarpackie, lubuskie, dolnośląskie i mazowieckie) przynależność do odpowiedniego kwartyla pod względem PKB pc. pokrywa się z tym samym kwartylem pod względem WDB pp. Różnice w rankingu województw pod względem obu wskaźników ukazuje tabela 3.1.1. 
Tabela 3.1.1. Ranking województw pod względem PKB per capita i WDB na pracującego

\begin{tabular}{|c|c|c|c|c|}
\hline \multirow{2}{*}{ Województwo } & \multicolumn{2}{|c|}{ Rok 1995} & \multicolumn{2}{|c|}{ Rok 2010} \\
\hline & $P K B$ pc & $W D B p p$ & $P K B p c$ & $W D B p p$ \\
\hline dolnośląskie & 3 & 3 & 2 & 2 \\
\hline kujawsko-pomorskie & 6 & 7 & 10 & 8 \\
\hline lubelskie & 14 & 15 & 15 & 16 \\
\hline lubuskie & 7 & 6 & 9 & 10 \\
\hline łódzkie & 10 & 12 & 6 & 12 \\
\hline małopolskie & 11 & 11 & 8 & 9 \\
\hline mazowieckie & 1 & 2 & 1 & 1 \\
\hline opolskie & 9 & 10 & 11 & 7 \\
\hline podkarpackie & 15 & 13 & 16 & 14 \\
\hline podlaskie & 15 & 14 & 14 & 13 \\
\hline pomorskie & 5 & 4 & 5 & 4 \\
\hline śląskie & 2 & 1 & 3 & 6 \\
\hline świętokrzyskie & 13 & 16 & 12 & 15 \\
\hline warmińsko-mazurskie & 12 & 9 & 13 & 11 \\
\hline wielkopolskie & 7 & 8 & 4 & 5 \\
\hline zachodniopomoskie & 4 & 5 & 7 & 3 \\
\hline
\end{tabular}

Źródło: obliczenia własne

Mapy 3.1.1.1-3.1.1.4 oraz dane $\mathrm{z}$ tabeli 3.1.1 pokazują, że różnice w rankingu województw pod względem analizowanych zmiennych rosną w czasie, co może mieć znaczenie dla wniosku o konwergencji tych zjawisk i jest argumentem do osobnego analizowania obu wskaźników i nietraktowania ich substytucyjnie.

Różnice w rankingu województw ukazane w tabeli 3.1.1 powodują pewną trudność w ich jednoznacznym podziale na grupy zamożności, czy dobrobytu gospodarczego. Wynika to zarówno $\mathrm{z}$ faktu, że pozycje województw w rankingu wg PKB pc. i WDB pp. są nieco inne, jak i z faktu, że pod względem tego samego wskaźnika pozycja danego województwa była różna w zależności od roku badania ${ }^{4}$. Ostatecznie, w badaniach, w których wyróżniano kluby (klastry) województw, podział dotyczył następujących 3 grup „zamożności”:

1) województwa najuboższe w których skład wchodzą województwa Polski Wschodniej: lubelskie, podkarpackie, podlaskie, świętokrzyskie, warmińsko-mazurskie;

2) województwa o średnim poziomie zamożności: kujawsko-pomorskie, lubuskie, łódzkie, małopolskie, opolskie.

\footnotetext{
${ }^{4}$ Jedynie mazowieckie, w całym okresie badania (1995-2010) nie zmieniło swojej pierwszej pozycji pod względem PKB per capita. Stosunkowo największe zmiany w rankingu zanotowały województwa zaliczone do średniej grupy zamożności: łódzkie (pozycja 6-11 w zależności od roku analizy), zachodniopomorskie (4-7), kujawsko-pomorskie (6-10). Natomiast stosunkowo stabilne pozycje miały województwa najbiedniejsze - Polski Wschodniej.
} 
3) województwa najbogatsze składające się $\mathrm{z}$ województw: dolnośląskiego, pomorskiego, zachodniopomorskiego, śląskiego, wielkopolskiego ${ }^{5}$.

Województwo mazowieckie było albo wyłączane $\mathrm{z}$ analiz (tworzyło osobny „klub”), albo włączane było do grupy 3 - starano się wyraźnie to zaznaczyć w badaniach.

\subsubsection{Lączna produktywność czynników produkcji}

Weryfikacja występowania konwergencji technologicznej (TFP-konwergencji por. p. 1.3.2) wymagała kwantyfikacji wojewódzkich wartości $T F P$, które nie są bezpośrednio obserwowalne i wyznaczone zostały na podstawie formuly (por. podrozdział 1.3.2):

$$
T F P_{t}=\frac{Y_{t}}{K_{t}^{\alpha} L_{t}^{(1-\alpha)}}
$$

gdzie:

TFP - łączna produktywność czynników produkcji, $K_{t}$-kapitał fizyczny mierzony wartością brutto środków trwałych w cenach stałych z roku 2000, $L_{t}-$ zatrudnienie mierzone liczbą pracujących wg BAEL, $Y_{t}$ - produkcja mierzona wartością dodaną brutto $\mathrm{w}$ cenach stałych $\mathrm{z}$ roku 2000, $\alpha$ - elastyczność produkcji względem kapitału.

$\mathrm{W}$ pracy tej nie omówiono szerzej problemu sygnalizowanego w rozdziale 1.3.2.1, związanego ze sposobem wyznaczenia kapitału. Przyjęto, że będzie to wartość brutto środków trwałych (WBŚT) ${ }^{6}$.

Więcej miejsca zarezerwowano na ustalenie elastyczności produkcji względem kapitału $\alpha$ we wzorze (3.1.2.1). Jak już wspominano w podpunkcie 1.3.2.1 przy ustalaniu wartości elastyczności produkcji względem kapitału $\alpha$ możliwe są różne podejścia. Poniżej parametr ten oszacowano przy wykorzystaniu dwóch metod. Pierwsza polegała na wykorzystaniu wyników klasycznej teorii produkcji, tzn. przyjęcie, że wartość elastyczność produkcji względem liczby pracujących $(1-\alpha)$ jest równa udziałowi wynagrodzenia z tytułu pracy (koszty pracy)

\footnotetext{
${ }^{5}$ Mówienie o województwach najbogatszych (najzamożniejszych) i najbiedniejszych (najuboższych) jest może nazbyt wartościujące, lecz w intuicyjny (i czytelny) sposób obrazuje czytelnikowi różnice w poziomach gospodarczych mierzonych wartością PKB per capita.

${ }^{6}$ Choć należy zaznaczyć, że przy innej definicji tej zmiennej (kapitał wyliczany wg formuły 1.2.2, w której należy zadecydować o początkowej wartości kapitału oraz stopie jego deprecjacji) można otrzymać słabsze lub silniejsze tempo konwergencji technicznego uzbrojenia pracy (kapitału na pracującego). Po przeprowadzeniu wielu symulacji wydawało się, że przyjęcie wartości brutto środków trwałych (wraz z odpowiednim ich deflatorem) jest optymalnym rozwiązaniem.
} 
w produkcji danego regionu ${ }^{7}$. Wartości tak wyliczonej elastyczności podaje tabela 3.1.2.1.

Tabela 3.1.2.1. Oszacowanie parametru $\alpha$ przy wykorzystaniu relacji kosztów pracy w wielkości produkcji

\begin{tabular}{|l|c|c|c|}
\hline \multicolumn{1}{|c|}{ Województwo } & Rok 1995 & Rok 2010 & $\begin{array}{c}\text { Średnia } \\
\text { dla lat 1995-2010 }\end{array}$ \\
\hline dolnośląskie & 0,55 & 0,60 & 0,56 \\
\hline kujawsko-pomorskie & 0,58 & 0,59 & 0,57 \\
\hline lubelskie & 0,57 & 0,57 & 0,56 \\
\hline lubuskie & 0,54 & 0,59 & 0,57 \\
\hline tódzkie & 0,57 & 0,60 & 0,58 \\
\hline małopolskie & 0,54 & 0,56 & 0,55 \\
\hline mazowieckie & 0,55 & 0,58 & 0,57 \\
\hline opolskie & 0,54 & 0,58 & 0,56 \\
\hline podkarpackie & 0,54 & 0,55 & 0,53 \\
\hline podlaskie & 0,57 & 0,60 & 0,58 \\
\hline pomorskie & 0,56 & 0,58 & 0,56 \\
\hline śląskie & 0,49 & 0,56 & 0,53 \\
\hline świętokrzyskie & 0,58 & 0,59 & 0,58 \\
\hline warmińsko-mazurskie & 0,56 & 0,59 & 0,56 \\
\hline wielkopolskie & 0,58 & 0,60 & 0,59 \\
\hline zachodniopomorskie & 0,56 & 0,61 & 0,58 \\
\hline Średnia & $\mathbf{0 , 5 5}$ & $\mathbf{0 , 5 8}$ & $\mathbf{0 , 5 6}$ \\
\hline
\end{tabular}

Źródło: obliczenia własne

Z powyższej tabeli wynika, że ani różnice w czasie, ani w przestrzeni tak oszacowanego parametru $\alpha$ nie są duże. Różnice w czasie pokazują niewielkie fluktuacje, które można podzielić (czego nie widać w powyższej tabeli) na trzy podokresy: 1995-1998, 1999-2003, 2004-2010, kiedy to wartości $\alpha$ odpowiednio malały, rosły i ponownie malały. Różnice w przestrzeni mogą być zobrazowane zmiennością średnich wartości dla poszczególnych województw (z ostatniej kolumny tabeli 3.1.2.1), które znajdują się w przedziale 0,53-0,59 (średnio 0,56 jak dla Polski).

Drugim sposobem ustalenia regionalnych elastyczności $\alpha$ jest oszacowanie równania funkcji wydajności pracy postaci ${ }^{8}$ :

\footnotetext{
${ }^{7}$ Por. Malaga [2010, s. 44]. Pozostaje kwestia jakiego miernika produkcji należy użyć. Suma nadwyżki operacyjnej brutto i kosztów pracy jest najbliższa wartości dodanej brutto, a nie PKB, ani tym bardziej produkcji sprzedanej.

${ }^{8}$ Przekształcenie funkcji produkcji (1.2.1.1) do postaci funkcji wydajności pracy pozwala uniknąć nakładania restrykcji na oryginalne równanie, w którym zakłada się sumowalność do 1 wszystkich elastyczności produkcji. W równaniu tym, jak i poniższych pominięto wyraz wolny i składnik losowy.
} 


$$
\left(\frac{Y}{L}\right)_{i t}=T F P_{i t}^{g_{i}} *\left(\frac{K}{L}\right)_{i t}^{\alpha_{i}} \rightarrow \ln \left(\frac{Y}{L}\right)_{i t}=g_{i} \ln (T F P)_{i t}+\alpha_{i} \ln \left(\frac{K}{L}\right)_{i t}
$$

gdzie:

- $\left(\frac{Y}{L}\right)_{i t}$ - wydajność pracy w regionie $i$, okresie $t$,

- $T F P_{i t}$ - łączna produktywność czynników produkcji w regionie $i$, okresie $t$,

- $\left(\frac{K}{L}\right)_{i t}$ - techniczne uzbrojenie pracy (kapitał na pracującego) w regionie $i$ okresie $t$,

- $\quad \alpha_{i}$ - elastyczność produkcji względem kapitału w regionie $i$,

- $g_{i}$ - tempo wzrostu TFP (postępu technologicznego) w regionie $i$,

- $\quad i=1, \ldots, 16, t=1995, \ldots, 2010$.

W równaniu tym, nieznane są wartości TFP, co rozwiązuje się najczęściej poprzez przyjęcie, że jest to wykładnicza funkcja czasu (lub po prostu zmienna czasowa, jeśli weźmie się pod uwagę logarytmy zmiennych). Przyjmując, że równanie to będzie szacowane dla poszczególnych regionów osobno, to dla poszczególnych województw będzie ono miało postać:

$$
\ln \left(\frac{Y_{t}}{L_{t}}\right)=g t+\alpha \ln \left(\frac{K_{t}}{L_{t}}\right)
$$

lub w postaci temp wzrostu:

$$
\ln \left(\frac{Y_{t}}{L_{t}}\right)-\ln \left(\frac{Y_{t-1}}{L_{t-1}}\right)=\alpha\left(\ln \left(\frac{K_{t}}{L_{t}}\right)-\ln \left(\frac{K_{t-1}}{L_{t-1}}\right)\right)
$$

Równanie (3.1.2.4) pozwala na uniknięcie efektów ewentualnej niestacjonarności zmiennych lecz jednocześnie nie pozwala na oszacowanie efektów postępu technicznego. Sposobem, który rozwiązuje oba te problemy i dodatkowo porządkuje kwestię egzogeniczności zmiennych jest zastosowanie modelu typu Vector Error Correction Model - VECM (użytego w tym samym celu przez Gradzewicza i Kolasę [2004, s. 15-16]). Model VECM, eliminuje negatywne skutki niestacjonarności zmiennych oraz pozwala na oszacowanie parametru $\alpha$ (odczytywanego z relacji długookresowej), jak i na oszacowanie stopy postępu technologicznego (dzięki zastosowaniu postaci VECM z tzw. ograniczonym trendem ${ }^{9}$ ).

9 W modelach VECM wyraźnie odróżnia się pozycję wyrazu wolnego i trendu: włączone w relację kointegracyjną (postać ograniczona) lub poza nią (postać nieograniczona) - por. p. 
Wyniki oszacowania elastyczności $\alpha$ kolejno dla 16 województw wg różnych wariantów równania (3.1.2.3) pokazane w tabeli 3.1.2.2 wskazują na zdecydowanie większe (niż w przypadku wyników z tabeli 3.1.2.1) zróżnicowanie tych wartości pomiędzy województwami. Widać również, że wysokie wartości elastyczności produkcji względem kapitału są zazwyczaj ujemnie skorelowane z tempem wzrostu postępu technologicznego, co poprzez wzór 1.2.1.2 ma wpływ na konwergencję: im wyższa elastyczność produkcji względem kapitału (niższe tempo postępu technologicznego) tym niższe tempo konwergencji.

Tabela 3.1.2.2. Oszacowanie elastyczności produkcji względem kapitału na podstawie różnych wariantów równania 3.1.2.3

\begin{tabular}{|c|c|c|c|c|c|c|c|}
\hline \multirow{2}{*}{$\begin{array}{c}\text { Równanie: } \\
\text { Nr kolumny: }\end{array}$} & \multicolumn{2}{|c|}{$\begin{array}{c}\text { 3.1.2.3 z wyrazem } \\
\text { wolnym }\end{array}$} & \multicolumn{2}{|c|}{$\begin{array}{c}\text { 3.1.2.3 bez wyrazu } \\
\text { wolnego }\end{array}$} & \multirow{2}{*}{$\begin{array}{c}3.1 .2 .4 \\
(5)\end{array}$} & \multicolumn{2}{|c|}{$\begin{array}{l}\text { 3.1.2.3 w postaci } \\
\text { VECM }\end{array}$} \\
\hline & (1) & $(2)$ & (3) & (4) & & (6) & (7) \\
\hline Województwo & $g$ & $\alpha$ & $g$ & $\alpha$ & $\alpha$ & $\alpha$ & $g$ \\
\hline dolnośląskie & $2,1 \%$ & 0,61 & $1,5 \%$ & 0,82 & 0,58 & 0,64 & $1,9 \%$ \\
\hline kujawsko-pom. & $1,6 \%$ & 0,76 & $1,4 \%$ & 0,82 & 0,81 & 0,40 & $2,1 \%$ \\
\hline lubelskie & $2,5 \%$ & 0,09 & $1,5 \%$ & 0,76 & 0,17 & 0,40 & $2,1 \%$ \\
\hline lubuskie & $0,7 \%$ & 0,66 & $0,4 \%$ & 0,82 & 0,81 & 0,81 & $0,3 \%$ \\
\hline łódzkie & $2,0 \%$ & 0,73 & $1,8 \%$ & 0,80 & 0,64 & 0,89 & $1,4 \%$ \\
\hline małopolskie & $4,3 \%$ & $-0,04$ & $1,8 \%$ & 0,80 & 0,43 & 0,83 & $1,1 \%$ \\
\hline mazowieckie & $3,5 \%$ & 0,44 & $2,8 \%$ & 0,79 & 0,26 & 0,53 & $1,5 \%$ \\
\hline opolskie & $2,8 \%$ & 0,52 & $2,2 \%$ & 0,75 & 0,50 & 0,53 & $2,8 \%$ \\
\hline podkarpackie & $1,0 \%$ & 0,61 & $0,4 \%$ & 0,80 & 0,53 & 0,68 & $0,6 \%$ \\
\hline podlaskie & $1,9 \%$ & 0,70 & $1,7 \%$ & 0,77 & 0,78 & 0,77 & $1,5 \%$ \\
\hline pomorskie & $2,2 \%$ & 0,64 & $1,9 \%$ & 0,81 & 0,67 & 0,94 & $1,4 \%$ \\
\hline śląskie & $1,9 \%$ & 0,72 & $1,7 \%$ & 0,82 & 0,60 & 0,76 & $1,7 \%$ \\
\hline świętokrzyskie & $2,5 \%$ & 0,71 & $2,4 \%$ & 0,76 & 0,56 & 0,73 & $2,5 \%$ \\
\hline warmińsko-maz. & $1,6 \%$ & 0,49 & $1,4 \%$ & 0,79 & 0,24 & 0,70 & $1,2 \%$ \\
\hline wielkopolskie & $3,9 \%$ & 0,16 & $1,9 \%$ & 0,81 & 0,58 & 0,76 & $1,5 \%$ \\
\hline zachodniopom. & $2,9 \%$ & 0,22 & $1,5 \%$ & 0,80 & 0,32 & 0,43 & $2,4 \%$ \\
\hline Średnia & $2,3 \%$ & $\mathbf{0 , 5 0}$ & $1,6 \%$ & $\mathbf{0 , 8 0}$ & $\mathbf{0 , 5 3}$ & 0,67 & $1,6 \%$ \\
\hline
\end{tabular}

Źródło: obliczenia własne

Najbardziej zróżnicowane pomiędzy województwami są oszacowania $\alpha$ z drugiej kolumny (gdzie dodatkowo uzyskano mało wiarygodną wartość dla województwa małopolskiego). Stosunkowo najmniej zróżnicowane są wyniki z kolumny nr 4 - lecz uzyskane wartości są tak wysokie, że trudno znaleźć ich potwierdzenie w literaturze przedmiotu. Tymczasem wartości parametru $\alpha$ są wg VECM wyższe (przeciętnie) zaś tempo wzrostu postępu technicznoorganizacyjnego niższe niż w przypadku jednorównaniowych modeli dla poszczególnych regionów w postaci równania (3.1.2.3).

2.4.2. Ma to wpływ na procesy generujące zmienne i w konsekwencji na liczbę wektorów kointegracyjnych i ich postać. W niniejszym rozdziale wybrano model z nieograniczonym wyrazem wolnym i ograniczonym trendem, co z jeden strony pozwala dobrze odzwierciedlić procesy generujące zmienne, z drugiej - umożliwia oszacowanie efektów postępu techniczno-organizacyjnego. $\mathrm{W}$ modelach tych używano takiego rzędu autoregresji, który eliminował autokorelację składnika losowego. 
Wobec takiej różnorodności wyników w tabeli 3.1.2.2 (która jednocześnie potwierdza wagę wyboru metody szacowania $\alpha$ ) zdecydowano ostatecznie, że w badaniach, w których różnicowano regionalnie wartości elastyczności produkcji, przyjęto wyniki z ostatniej kolumny tabeli 3.1.2.1.

W badaniach gdzie przyjmowano taką samą we wszystkich województwach elastyczność $\alpha$, przyjęto wartość $\alpha=0,57$, która jest średnią arytmetyczną z wartości 0,56 (średniej dla województw z ostatniej komórki w tabeli 3.1.2.1) oraz wartości 0,58 , która wynika $\mathrm{z}$ funkcji regresji typu (3.1.2.3) dla danych połączonych w panel (tzw. pooled regression) - przeprowadzonej w celu otrzymania wspólnej dla województw wartości $\alpha^{10}$ :

$$
\ln \left(\frac{Y}{L}\right)_{i t}=0,95+0,02 * t+0,58 * \ln \left(\frac{K}{L}\right)_{i t}
$$

Na koniec pokazano wpływ jaki mają różne wartości parametru $\alpha$ na dynamikę regionalnych $T F P$ por. tabela 3.1.2.3.

Tabela 3.1.2.3. Średnioroczna dynamika TFP w zależności od wartości parametru $\alpha$ w równaniu 3.1.2.1

\begin{tabular}{|c|c|c|c|c|c|c|}
\hline Województwo & $\begin{array}{c}\alpha=0,57 \text { we } \\
\text { wszystkich } \\
\text { wojew. }\end{array}$ & $\begin{array}{c}\alpha \text { wg kol. } \\
(2) \\
\text { z tabeli } \\
3.1 .2 .2 \\
\end{array}$ & $\begin{array}{c}\alpha \text { wg kol. } \\
(4) \\
\text { z tabeli } \\
3.1 .2 .2 \\
\end{array}$ & $\begin{array}{c}\alpha \text { wg kol. } \\
(5) \\
z \text { tabeli } \\
\text { 3.1.2.2 } \\
\end{array}$ & $\begin{array}{c}\alpha \text { wg kol. } \\
(7) \\
\text { z tabeli } \\
\text { 3.1.2.2 } \\
\end{array}$ & $\begin{array}{c}\alpha \text { wg ost. } \\
\text { kol. } \\
\text { z tabeli } \\
\text { 3.1.2.1 } \\
\end{array}$ \\
\hline dolnośląskie & $2,0 \%$ & $1,8 \%$ & $1,1 \%$ & $1,9 \%$ & $1,7 \%$ & $2,0 \%$ \\
\hline kujawsko-pom. & $1,9 \%$ & $1,3 \%$ & $1,1 \%$ & $1,2 \%$ & $2,4 \%$ & $1,9 \%$ \\
\hline lubelskie & $1,6 \%$ & $2,5 \%$ & $1,2 \%$ & $2,3 \%$ & $1,9 \%$ & $1,6 \%$ \\
\hline lubuskie & $0,7 \%$ & $0,5 \%$ & $0,1 \%$ & $0,1 \%$ & $0,1 \%$ & $0,7 \%$ \\
\hline łódzkie & $2,2 \%$ & $1,8 \%$ & $1,6 \%$ & $2,0 \%$ & $1,4 \%$ & $2,2 \%$ \\
\hline małopolskie & $2,3 \%$ & $4,4 \%$ & $1,5 \%$ & $2,8 \%$ & $1,4 \%$ & $2,4 \%$ \\
\hline mazowieckie & $3,0 \%$ & $3,4 \%$ & $2,5 \%$ & $3,9 \%$ & $3,1 \%$ & $3,0 \%$ \\
\hline opolskie & $2,4 \%$ & $2,6 \%$ & $1,9 \%$ & $2,6 \%$ & $2,6 \%$ & $2,5 \%$ \\
\hline podkarpackie & $1,0 \%$ & $0,8 \%$ & $0,2 \%$ & $1,1 \%$ & $0,6 \%$ & $1,1 \%$ \\
\hline podlaskie & $2,1 \%$ & $1,7 \%$ & $1,5 \%$ & $1,4 \%$ & $1,5 \%$ & $2,1 \%$ \\
\hline pomorskie & $2,3 \%$ & $2,1 \%$ & $1,7 \%$ & $2,0 \%$ & $1,4 \%$ & $2,3 \%$ \\
\hline śląskie & $1,7 \%$ & $1,5 \%$ & $1,3 \%$ & $1,7 \%$ & $1,4 \%$ & $1,8 \%$ \\
\hline świętokrzyskie & $2,7 \%$ & $2,5 \%$ & $2,4 \%$ & $2,7 \%$ & $2,4 \%$ & $2,7 \%$ \\
\hline warmińsko-maz. & $1,4 \%$ & $1,5 \%$ & $1,2 \%$ & $1,8 \%$ & $1,3 \%$ & $1,4 \%$ \\
\hline wielkopolskie & $2,3 \%$ & $3,8 \%$ & $1,3 \%$ & $2,2 \%$ & $1,5 \%$ & $2,2 \%$ \\
\hline zachodniop. & $1,8 \%$ & $2,8 \%$ & $1,1 \%$ & $2,5 \%$ & $2,2 \%$ & $1,8 \%$ \\
\hline Średnia & $2,0 \%$ & $2,2 \%$ & $1,4 \%$ & $2,0 \%$ & $1,7 \%$ & $2,0 \%$ \\
\hline
\end{tabular}

Źródło: obliczenia własne

${ }^{10}$ Należy zauważyć jednocześnie, że tempo wzrostu postępu technologicznego z równania (3.1.2.5) na poziomie $2 \%$ rocznie jest zbliżone do szacunków widocznych w ostatnim wierszu tabeli 3.1.2.2, jak i tabeli 3.1.2.3. 


\subsubsection{Stopy deprecjacji kapitału regionalnego}

Stopa deprecjacji kapitału $\delta$ jest parametrem, który oddziałuje na konwergencję w wieloraki sposób: jest jedną ze zmiennych objaśniających w modelu Solowa postaci (2.1.1.6), podwyższa tempo konwergencji we wzorze (1.2.5) oraz wpływa na wartości w stacjonarnych stanach równowagi (por. wzory 1.2.1.61.2.1.9).

Jak już pisano w podrozdziale 1.3.2.1 przy ustaleniu stopy deprecjacji kapitału można używać różnych podejść. Jednym z nich jest przyjęcie pewnej arbitralnej wartości. Na podstawie studiów literaturowych można zauważyć, że stosunkowo często wykorzystywaną wartością jest $\delta=0,05$ lub rzadziej $\delta=0,06$, choć jak już sygnalizowano w podrozdziale 1.3.2.1, stopa amortyzacji kapitału może się różnić zarówno pomiędzy sektorami gospodarki, jak i regionami.

W niniejszej pracy przeprowadzono dwa eksperymenty w celu ustalenia właściwej, dla okresu analizy, stopy deprecjacji oraz stwierdzenia, czy można przyjąć, ze jest ona regionalnie niezróżnicowana. Pierwszy polegał na oszacowaniu stopy deprecjacji przy wykorzystaniu zależności:

$$
K_{t}=K_{t-1}+I_{t}-\delta K_{t-1}=(1-\delta) K_{t-1}+I_{t}
$$

którą przekształcono do postaci:

$$
\delta=1-\frac{K_{t}-I_{t}}{K_{t-1}}
$$

gdzie: $K$ jest miarą kapitału w poszczególnych regionach, a $I$ miarą inwestycji.

Przy założeniu znajomości zmiennych $K$ i $I$ ( $K$ - przyjęto na poziomie wartości brutto środków trwałych, $I$ - nakładów brutto na środki trwałe) wyliczono stopy deprecjacji w kolejnych latach, a następnie policzono średnią. Efekty tej procedury przedstawia tabela 3.1.3.1 z której wynika, że stopa deprecjacji różni się pomiędzy województwami (oraz, co pokazały szczegółowe wyniki nie zawarte w tabeli, nieznacznie rośnie też w czasie). Jej średnia wartość $(0,054)$ jest bliska wartościom przyjmowanym w literaturze.

Wykorzystano również metodę zaproponowaną w podrozdziale 1.3.2.1, nazwijmy ją „księgową”, polegającą na wykorzystaniu wiedzy o strukturze mająt$\mathrm{ku}$ produkcyjnego przedsiębiorstw i stopie amortyzacji poszczególnych jego składników. Zgodnie z zapisami ustawowymi ${ }^{11}$ czas amortyzacji środka trwałego takiego jak budynki i budowle to $2,5 \%$ rocznie (dla budynków niemieszkalnych) lub 4,5\% (dla podziemnych garaży i zadaszonych parkingów), co odpo-

\footnotetext{
${ }^{11}$ Zob. Ustawa o podatku dochodowym od osób fizycznych, Dz.U., 2012 poz. 361 oraz Ustawa o podatku dochodowym od osób prawnych, Dz.U.,2011, 74, poz. 397.
} 
wiada 22-letniemu do 40-sto letniemu okresowi ich użytkowania i przekłada się na współczynnik amortyzacji rzędu $\delta_{\text {bud }}=0,025-0,045$ (średnio $\left.\delta_{\text {bud }}=0,035\right)^{12}$. Stawka amortyzacyjna dla maszyn i urządzeń to od $7 \%$ (np. dla kotłów i maszyn energetycznych) do $30 \%$ (dla zespołów komputerowych) rocznie. Dla trzeciego, ostatniego składnika majątku przedsiębiorstw - środków transportu, przyjmuje się najczęściej 5-cio letni okres amortyzacji (choć przepisy przewidują zmniejszenie tego okresu do minimalnie 30-stu miesięcy) co odpowiada $\delta_{\text {transp }}=0,2$. Ostatecznie wartości stóp amortyzacji dla różnych składników majątku są zróżnicowane: od $\delta=0,025$ dla wybranych budynków i budowli do ośmiokrotnie wyższego $\delta=0,2$ dla środków transportu. Dostępne autorce dane statystyczne nie pozwalały na dokonanie podobnych wyliczeń w poszczególnych województwach, dlatego powyższe dane posłużyły jedynie do wyliczenia średniej stopy deprecjacji (do czego wykorzystano dodatkowo udział, jaki ma dany rodzaj środka trwałego w ogólnej wartości środków trwałych raportowany w opracowaniach ,Środki trwate w gospodarce narodowej, [różne lata]"). Z obliczeń wynika, że tak oszacowana (tzn. poprzez wykorzystanie wiedzy o strukturze środków trwałych oraz wiedzy o czasie amortyzacji poszczególnych składników majątku przedsiębiorstw), średnia stopa deprecjacji kapitału dla wszystkich składników majątku wynosi $\delta=0,074$.

Tabela 3.1.3.1. Stopa deprecjacji kapitału w województwach

\begin{tabular}{|l|c|}
\hline \multicolumn{1}{|c|}{ Województwo } & $\begin{array}{c}\text { Średnia (2000-2010) stopa deprecjacji wyliczona } \\
\text { ze wzoru 3.1.3.2 }\end{array}$ \\
\hline dolnośląskie & 0,059 \\
\hline kujawsko-pomorskie & 0,060 \\
\hline lubelskie & 0,043 \\
\hline lubuskie & 0,051 \\
\hline lódzkie & 0,062 \\
\hline małopolskie & 0,057 \\
\hline mazowieckie & 0,060 \\
\hline opolskie & 0,037 \\
\hline podkarpackie & 0,039 \\
\hline podlaskie & 0,046 \\
\hline pomorskie & 0,067 \\
\hline śląskie & 0,060 \\
\hline świętokrzyskie & 0,055 \\
\hline warmińsko-mazurskie & 0,055 \\
\hline wielkopolskie & 0,062 \\
\hline zachodniopomorskie & 0,050 \\
\hline Średnia & $\mathbf{0 , 0 5 4}$ \\
\hline
\end{tabular}

Źródło: obliczenia własne

${ }^{12} \mathrm{~W}$ badaniu Welfe, Florczak [2004] przyjęto wartość $\delta_{b u d}=0,0135$, choć autorzy przyznają, że przyjęta przez nich wartość jest niższa niż dla standardów europejskich. 
Ostatecznie, biorąc pod uwagę obie powyższe symulacje, w których uzyskano średnie (dla województw) stopy amortyzacji rzędu $\delta=0,054$ i $\delta=0,074$, wspólną dla wszystkich regionów stopę deprecjacji przyjęto na poziomie $\delta=0,06$.

\subsubsection{Dane sektorowe}

Pewnym problemem związanym z danymi używanymi do badań sektorowych był sposób ich agregacji do sektorów gospodarczych: według klasyfikacji PKD 2004 lub PKD 2007 - por. tabela 3.1.4.1 ${ }^{13}$. Ostatecznie, pomimo, że klasyfikacja PKD 2004 nie obowiązuje w Polsce od początku roku 2010, to zdecydowano się jej użyć jako podstawy agregacji, a klasyfikację PKD 2007 wykorzystano jedynie do przedłużenia szeregów danych o rok 2009 (WDB) i 2010 (liczba pracujących). Powód takiego działania był natury praktycznej: w momencie przystępowania do obliczeń nie było informacji dotyczących niektórych zmiennych według PKD 2007. Problem stanowiły głównie dane z rachunków regionalnych, a w szczególności wartość dodana brutto, której wartości według PKD 2007 w ogóle nie były znane w momencie tworzenia banków danych do obliczeń (pierwsze dane o wojewódzkim WDB według PKD 2007 - za 2009 r. zostały opublikowane przez GUS 03.01.2012 r., a w dniu 29 lutego 2012 r., w rachunkach regionalnych były trzy obserwacje roczne o wojewódzkich $\left.\mathrm{WDB}^{14}\right)$.

Rozszerzenie liczby sekcji, zmiana ich zawartości i „lokalizacji” w nowej klasyfikacji PKD (por. tabela 3.1.4.1) powodują, że brak jest porównywalności pomiędzy klasyfikacjami PKD 2004 i PKD 2007 na poziomie sekcji, a w konsekwencji na poziomie sektorów. Pełna zgodność została zachowana jedynie na ogólnonarodowym poziomie. W przypadku podziału sektorowego, stosunkowo niewielkie różnice występują w sektorze rolnym i przemysłowym, ale już w przypadku usług rynkowych i nierynkowych różnice są znaczące. Fakty te powodują niemożność stosowania wprost klasyfikacji PKD 2007 w celu uzupełnienia szeregów danych o wartości dla roku 2009 i 2010, niemniej przyjęty algorytm postępowania (wykorzystujący dynamiki, a nie bezwzględne wartości zmiennych $\mathrm{w}$ obu klasyfikacjach) doprowadził do stosun-

\footnotetext{
${ }^{13}$ Polska Klasyfikacji Działalności 2004 (PKD 2004) jest zgodna z europejską klasyfikacją statystyczną NACE rev. 1.1, (Nomenclature statistique des Activités économiques dans la Communauté Européenne, revision 1.1 - Statystyczna Klasyfikacja Działalności Gospodarczych w Unii Europejskiej) i stosowana była w Polsce do końca roku 2009. Od początku roku $2010 \mathrm{w}$ Polsce obowiązuje Polska Klasyfikacja Działalności 2007 (PKD 2007) - opracowana w ramach "Operacji 2007", na podstawie statystycznej klasyfikacji działalności gospodarczej NACE rev.2 (która zastąpiła NACE rev. 1.1.). Nowa klasyfikacja PKD 2007 spowodowała zmianę liczby sekcji (z 17 do 21) i zmianę ich grupowania do poszczególnych sektorów - por. tabela 3.1.4.1.

${ }^{14}$ GUS ma w planach przeliczenie danych wg PKD 2007 do 2000 r., lecz proces ten będzie zakończony najwcześniej w połowie roku 2012.
} 
kowo dużej zgodności obu klasyfikacji i, w konsekwencji, umożliwił ciągłość danych statystycznych dla 4 sektorów gospodarczych.

Tabela 3.1.4.1. Agregacja sekcji PKD 2004 i PKD 2007 do czterech sektorów gospodarki

\begin{tabular}{|c|c|c|c|c|}
\hline Sektory & \multicolumn{2}{|r|}{ Sekcje PKD 2004} & \multicolumn{2}{|r|}{ Sekcje PKD 2007} \\
\hline \multirow{2}{*}{ Sektor rolniczy } & A & Rolnictwo, łowiectwo, leśnictwo & \multirow{2}{*}{ A } & \multirow{2}{*}{$\begin{array}{l}\text { Rolnictwo, leśnictwo, łowiectwo } \\
\text { i rybactwo }\end{array}$} \\
\hline & B & Rybactwo & & \\
\hline \multirow{5}{*}{$\begin{array}{l}\text { Sektor prze- } \\
\text { mysłowy }\end{array}$} & $\mathrm{C}$ & Górnictwo & $\mathrm{B}$ & Górnictwo i wydobywanie \\
\hline & $\mathrm{D}$ & Przetwórstwo przemysłowe & $\mathrm{C}$ & Przetwórstwo przemysłowe \\
\hline & \multirow[t]{2}{*}{$\mathrm{E}$} & \multirow{2}{*}{$\begin{array}{l}\text { Wytwarzanie i zaopatrywanie } \\
\text { w energię elektryczną, gaz wodę }\end{array}$} & $\mathrm{D}$ & $\begin{array}{l}\text { Wytwarzanie i zaopatrywanie w energie } \\
\text { elektryczną, gaz, parę wodną gorącą wo- } \\
\text { dę i powietrze do układów klimatyzacyj- } \\
\text { nych }\end{array}$ \\
\hline & & & $\mathrm{E}$ & $\begin{array}{l}\text { Dostawy wody; gospodarowanie ściekami } \\
\text { i odpadami oraz działalność związana } \\
\text { z rekultywacją }\end{array}$ \\
\hline & $\mathrm{F}$ & Budownictwo & $\mathrm{F}$ & Budownictwo \\
\hline \multirow{6}{*}{$\begin{array}{l}\text { Sektor usług } \\
\text { rynkowych }\end{array}$} & G & $\begin{array}{l}\text { Handel hurtowy i detaliczny; napra- } \\
\text { wa pojazdów samochodowych, mo- } \\
\text { tocykli oraz artykułów użytku osobi- } \\
\text { stego i domowego }\end{array}$ & G & $\begin{array}{l}\text { Handel hurtowy i detaliczny; naprawa po- } \\
\text { jazdów samochodowych, włączając mo- } \\
\text { tocykle }\end{array}$ \\
\hline & $\mathrm{H}$ & Hotele i restauracje & $\mathrm{H}$ & Transport i gospodarka magazynowa \\
\hline & \multirow{2}{*}{ I } & \multirow{2}{*}{$\begin{array}{l}\text { Transport, gospodarka magazynowa } \\
\text { i łączność }\end{array}$} & I & $\begin{array}{l}\text { Działalność związana z zakwaterowaniem } \\
\text { i usługami gastronomicznymi }\end{array}$ \\
\hline & & & $\mathrm{J}$ & Informacja i komunikacja \\
\hline & $\mathrm{J}$ & Pośrednictwo finansowe & $\mathrm{K}$ & Działalność finansowa i ubezpieczeniowa \\
\hline & $\mathrm{K}$ & $\begin{array}{l}\text { Obsługa nieruchomości, wynajem } \\
\text { i usługi związane z prowadzeniem } \\
\text { działalności gospodarczej }\end{array}$ & $\mathrm{L}$ & $\begin{array}{l}\text { Działalność związana z obsługą rynku } \\
\text { nieruchomości }\end{array}$ \\
\hline
\end{tabular}

${ }^{15} \mathrm{~W}$ tym sektorze zlokalizowane są głównie usługi oparte na zaawansowanej wiedzy - KIS (ang. knowledge-intensive services), które obejmują następujące sekcje i działy PKD 2004: sekcja J; sekcja K (w tym, dział 72: Informatyka i 73: Działalność badawczo-rozwojowa należące do tzw. usług opartych na wysoko zaawansowanej wiedzy - high-tech KIS). Do KIS należą również wybrane działy sekcji I.

Dwie pierwsze sekcje (J, K) należą do grupy, którą można nazwać rynkowymi usługami nowoczesnymi, sekcja M należy do sektora usług nierynkowych (które wraz z sekcjami dot. administracji publicznej i ochrony zdrowia są głównymi składowymi usług nierynkowych, czy mówiąc precyzyjnie: pozostałych). Sektor rynkowych usług tradycyjnych (sekcje G, H, I) zawiera, co prawda, jakąś część innowacyjnych usług sekcji I, lecz jest to udział na tyle niewielki, że trudno zaliczać tradycyjne usługi do KIS. 


\begin{tabular}{|c|c|c|c|c|}
\hline \multirow{9}{*}{$\begin{array}{l}\text { Sektor usług } \\
\text { nierynkowych } \\
\text { (pozostałych) }^{16}\end{array}$} & $\mathrm{~L}$ & $\begin{array}{l}\text { Administracja publiczna i obrona na- } \\
\text { rodowa; obowiązkowe ubezpieczenia } \\
\text { społeczne i powszechne ubezpiecze- } \\
\text { nie zdrowotne }\end{array}$ & M & $\begin{array}{l}\text { Działalność profesjonalna, naukowa } \\
\text { i techniczna }\end{array}$ \\
\hline & M & Edukacja & $\mathrm{N}$ & $\begin{array}{l}\text { Działalność w zakresie usług admini- } \\
\text { strowania i działalność wspierająca }\end{array}$ \\
\hline & $\mathrm{N}$ & Ochrona zdrowia i pomoc społeczna & $\mathrm{O}$ & $\begin{array}{l}\text { Administracja publiczna i obrona naro- } \\
\text { dowa; obowiązkowe zabezpieczenia spo- } \\
\text { łeczne }\end{array}$ \\
\hline & $\mathrm{O}$ & $\begin{array}{l}\text { Działalność usługowa komunalna, } \\
\text { społeczna i indywidualna, pozostała }\end{array}$ & $\mathrm{P}$ & Edukacja \\
\hline & $\mathrm{P}$ & $\begin{array}{l}\text { Gospodarstwa domowe zatrudniające } \\
\text { pracowników }\end{array}$ & Q & Opieka zdrowotna i pomoc społeczna \\
\hline & Q & Organizacje i zespoły eksterytorialne & $\mathrm{R}$ & $\begin{array}{l}\text { Działalność związana z kulturą, rozryw- } \\
\text { ka i rekreacją }\end{array}$ \\
\hline & & & S & Pozostała działalność usługowa \\
\hline & & & $\mathrm{T}$ & $\begin{array}{l}\text { Gospodarstwa domowe zatrudniające } \\
\text { pracowników; gospodarstwa domowe } \\
\text { produkujące wyroby i świadczące usługi } \\
\text { potrzeby }\end{array}$ \\
\hline & & & $\mathrm{U}$ & Organizacje i zespoły eksterytorialne \\
\hline
\end{tabular}

Źródło: opracowanie własne

$\mathrm{Na}$ koniec uwaga terminologiczna. Usługi podzielono na rynkowe i nierynkowe, podczas gdy w tym ostatnim sektorze można wskazać wiele działalności, które trudno nazwać nierynkowymi (publicznymi). Bardziej adekwatną nazwą dla tych usług byłoby „usługi świadczone w interesie ogólnym”"17, który to termin jest stosowany w niektórych krajach europejskich. Pomimo tych kontrowersji zastosowano nazwę , usługi nierynkowe” przy zastrzeżeniu, że jest to sektor zdefiniowany jak w tabeli 3.1.4.1.

\footnotetext{
${ }^{16}$ Należy zauważyć, że do $2006 \mathrm{r}$. dane prezentowane w podziale na sektory ekonomiczne, pochodzące z „Produkt Krajowy Brutto - Rachunki regionalne [różne lata]” były podzielone na pięć grup sekcji PKD 2004. W odróżnieniu od sposobu agregacji sekcji PKD prezentowanego w wydaniach z 2007 i 2008 r. sekcje "Działalność usługowa komunalna, społeczna i indywidualna, pozostała" oraz "Gospodarstwa domowe zatrudniające pracowników" były zaliczane do sektora usług rynkowych.

${ }^{17}$ Usługi świadczone w interesie ogólnym (services of general interest) obejmują zarówno usługi interesu ogólnego świadczone na zasadach rynkowych - komercyjnych (market services of general interest), jak i nierynkowych - niekomercyjnych (non-market services of general interest).
} 


\subsection{Konwergencja PKB per capita i WDB na pracującego}

\subsubsection{Beta-konwergencja absolutna $i$ warunkowa}

Test beta konwergencji absolutnej postaci (2.1.1.1) nie wskazuje na ten proces w Polsce ani dla WDB na pracującego (WDB_pp), ani dla PKB na mieszkańca $\left(P K B \_p c\right)$, o czym świadczą wykresy $3.2 .1 \mathrm{a}-3.2 .1 \mathrm{~b}$ oraz oszacowania równania $(2.1 .1 .1)^{18}$ :

$$
\begin{aligned}
& \ln \left(\frac{P K B_{-} p c_{i, 2010}}{P K B_{-} p c_{i, 1995}}\right)=-0,13+0,28^{*} \ln \left(P K B_{-} p c_{i, 1995}\right), \mathrm{R}^{2}=0,14 \\
& \ln \left(\frac{W D B_{-} p p_{i, 2010}}{W D B_{-} p p_{i, 1995}}\right)=0,34+0,04 \ln \left(W D B_{-} p p_{i, 1995}\right), \mathrm{R}^{2}=0,01^{19}
\end{aligned}
$$

gdzie: $i=1, \ldots, 16^{20}$.

Znaki parametrów przy zmiennych objaśniających są dodatnie, co mogłoby wskazywać na dywergencję zarówno PKB per capita, jak i WDB na pracującego (z tempem rozbieżności rzędu odpowiednio $1,6 \%$ oraz $0,3 \%$ rocznie ${ }^{21}$. Należy jednakże podkreślić, że współczynnik przy zmiennej objaśniającej w równaniu dla WDB jest nieistotny statystycznie (co przekłada się na niewielkie tempa rocznej rozbieżności). Ostatecznie, jeśli poszukuje się jedynie konwer-

\footnotetext{
${ }^{18}$ Należy zauważyć, że w regresjach przekrojowych typu (3.2.1.1a)-(3.2.1.1b) nie ma dużego znaczenia, czy zmienne są wyrażone w cenach bieżących, czy w cenach stałych. Ma to wpływ głównie na wyraz wolny, jeśli deflator PKB (WDB) jest taki sam w poszczególnych województwach (a tak przyjęto w niniejszym badaniu). Kwestia urealniania danych nabiera znaczenia w przypadku dołączenia do równania beta-konwergencji dodatkowych zmiennych (ze względu na inny deflator dla tych zmiennych). Niemniej od początku wszystkie dane zostały wyrażone w cenach stałych (z 2000 r.). Do przeliczeń użyto delfatora PKB i WDB pochodzącego z baz Eurostatu (Annual national accounts $\rightarrow$ GDP and main components - Price indices $\rightarrow$ Gross domestic product at market prices oraz Gross value added).

${ }^{19}$ Brak gwiazdek przy oszacowaniach parametrów oznacza, że były one nieistotne statystycznie (tzn. wówczas gdy empiryczny poziom istotności testu $p$ był mniejszy od 0,15 ). Jedna, dwie lub trzy gwiazdki oznaczają istotność statystyczną oszacowania odpowiednio na poziomie $15 \%, 10 \%$ i $5 \%$.

${ }^{20}$ Subskrypt $i$ oznacza w tym rozdziale zawsze tę samą próbę: $i=1, \ldots, 16$ województw, dlatego nie będzie dalej wyjaśniany.

${ }^{21}$ Należy przypomnieć, że alternatywną wersją równań (3.2.1.1a)-(3.2.1.1b) mogła być postać (2.1.1.4) wówczas oszacowania przy zmiennej objaśniającej byłyby 15 razy mniejsze $(0,0186$ zamiast 0,28 oraz 0,0026 zamiast 0,04 ), lecz użycie wówczas właściwego wzoru dla $\beta$, tzn. (2.1.1.5) zamiast (2.1.1.2) prowadzi to tych samych wniosków, co do tempa zbieżności (rozbieżności). Natomiast użycie wzoru (2.1.1.5) do wyników regresji (3.2.1.1a)-(3.2.1.1b) prowadziłoby do znacznego przeszacowania tempa rozbieżności.
} 
gencji - można stwierdzić jej brak w przypadku obu badanych zmiennych - co potwierdzają nachylenia prostych na poniższych wykresach.

Wykres 3.2.1a. Beta-konwergencja absolutna wojewódzkich PKB per capita

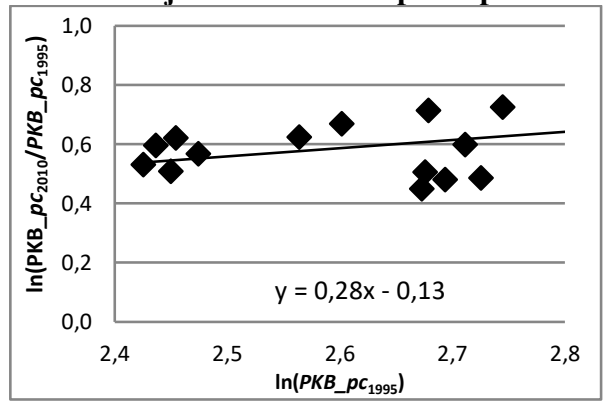

Wykres 3.2.1b. Beta-konwergencja absolutna wojewódzkich WDB na pracującego

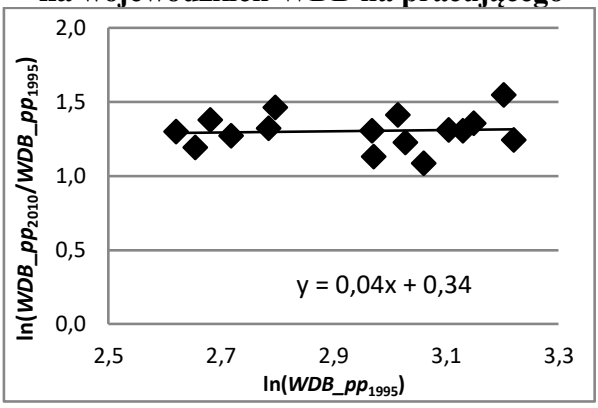

Źródło: opracowanie własne

Brak beta-konwergencji absolutnej nie wyklucza występowania innego jej rodzaju - beta-konwergencji warunkowej (por. p. 1.2.1). Ideą beta-konwergencji absolutnej jest odwrotnie proporcjonalna zależność pomiędzy początkową wartością zjawiska a jego tempem wzrostu (co oznacza, że województwa początkowo biedniejsze powinny wykazać się wyższymi tempami wzrostu gospodarczego niż początkowo bogatsze). Wiadomo jednakże, że oprócz początkowego poziomu zmiennej, której tempo wzrostu jest badane, zależy ono od wielu innych czynników, które go warunkują. Czynnikami tymi mogą być różnorakie zmienne społeczno-gospodarcze, a ich uwzględnienie w modelach wzrostu prowadzi do weryfikacji hipotezy o konwergencji warunkowej ${ }^{22}$. W przypadku powyższych regresji wprowadzenie dodatkowych zmiennych jest uzasadnione również bardzo niskimi wartościami $\mathrm{R}^{2}$, świadczącymi o niedostatecznym objaśnieniu wzrostu gospodarczego ${ }^{23}$.

Najpierw uzupełniono równania (3.2.1.1a) - (3.2.1.1b) o zmienną wynikającą ze specyfikacji funkcji produkcji Cobba-Douglasa (por. 1.2.1) - o zmianę war-

${ }^{22}$ Równanie beta-konwergencji można również uzupełnić o efekty przestrzenne (por. p. 2.2.3), których występowanie jest jednakże mało prawdopodobne w przypadku próby 16 województw. Potwierdzają to statystyki Morana, których wartości dla dwóch skrajnych lat analizy nie pozwalały na odrzucenie hipotezy o braku autokorelacji przestrzennej (brak efektów przestrzennych) w wojewódzkich wartościach PKB per capita, jak i wydajności pracy. Dodanie wag przestrzennych do równań beta-konwergencji absolutnej dla tych zmiennych również pokazało, że oszacowania parametrów przy opóźnieniu przestrzennym (spatial lag), jak i błędzie przestrzennym (spatial error) są nieistotne statystycznie.

${ }^{23}$ Choć należy zauważyć, że w modelach dla danych przekrojowych o stosunkowo niewielkiej liczbie obserwacji (jak w przypadku próby 16 województw) nie należy spodziewać się wysokich wartości $\mathrm{R}^{2}$. Na niską wartość współczynników determinacji wpływa także transformacja zmiennej objaśnianej (przyrost) - wiadomo, że w modelach dla przyrostów zmiennych $\mathrm{R}^{2}$ jest niższy niż dla poziomów. 
tości kapitału (kapitał na pracującego $K \_p p$ dla równania wzrostu wydajności pracy, lub kapitału per capita - $K \_p c$ dla równania wzrostu PKB per capita) co doprowadziło do następujących oszacowań ${ }^{24}$ :

$\ln \left(\frac{P K B_{-} p c_{i, 2010}}{P K B_{-} p c_{i, 1995}}\right)=0,47 \ln \left(P K B_{-} p c_{i, 1995}\right)+0,21 \ln \left(\frac{K_{-} p c_{i, 2010}}{K_{-} p c_{i, 1995}}\right), \mathrm{R}^{2}=0,25$

$\ln \left(\frac{W D B_{-} p p_{i, 2010}}{W D B_{-} p p_{i, 1995}}\right)=0,02 \ln \left(W D B_{-} p p_{i, 1995}\right)+0,6 \ln \left(\frac{K_{-} p p_{i, 2010}}{K_{-} p p_{i, 1995}}\right), \mathrm{R}^{2}=0,28$

Zgodnie z modelem Solowa i koncepcją wysuniętą przez Barro i Sala-i-Martina [1992] warunkiem koniecznym zaistnienia konwergencji między regionami są malejące krańcowe produktywności kapitału (por. podrozdziały $1.1-1.2$ ). Jeśli jest on spełniony, to kapitał napływa do regionów, w których jego zasób (na pracującego lub na mieszkańca) jest niższy, a zatem produkt krańcowy - wyższy. Jeśli poziom stosowanej w regionach technologii jest zbliżony, to konwergencja technicznego uzbrojenia pracy (lub kapitału per capita) przekłada się na konwergencję wydajności pracy (lub PKB per capita). W przypadku polskich regionów szybkość zbieżności technicznego uzbrojenia pracy (lub kapitału na pracującego) wynosi $0,31 \%(0,47 \%)$ - jest niska, lecz dodatnia (wskazuje na zbieżność do stanu równowagi, a nie rozbieżność). Tymczasem, $\mathrm{z}$ równań (3.2.1.2a)-(3.2.1.2b) wynika, że pomimo dodatnia do nich kapitału ( $\left.k \_p c, k \_p p\right)$, ani wydajność pracy, ani PKB per capita nie wykazują zbieżności. Może to oznaczać, że albo nie jest spełnione założenie o malejącej krańcowej produktywności kapitału, albo założenie o podobnym poziomie zaawansowania technologicznego regionów, albo też analizowane regiony nie stanowią spójnej grupy gospodarek.

Aby to wyjaśnić przeprowadzono dodatkowy eksperyment polegający na rozszerzeniu grupy zmiennych objaśniających o czynniki z modelu Solowa postaci (2.1.1.6). W pierwszej kolejności należało przeprowadzić jego parametryzację, tzn. ustalić wartość stopy wzrostu pracujących $\left(n_{i}\right)$, stopy inwestycji $\left(s_{i}\right)$, stopy deprecjacji kapitału $(\delta)$ oraz tempo wzrostu postępu technologicznego $(g)$. Stopę deprecjacji ustalono na poziomie $\delta=0,06$ (zob. wyliczenia w podrozdziale 3.1.3), tempo wzrostu TFP na poziomie $g=2 \%$ (por. wartość oszacowania z mo-

\footnotetext{
${ }^{24}$ Pomijamy na razie zmienną wyrażającą łączną produktywność czynników produkcji (w funkcji Cobb-Douglasa TFP zastępuje się zmienną czasową, lecz jej wprowadzenie nie ma sensu w przypadku regresji przekrojowej). $\mathrm{W}$ równaniach pominięto oszacowanie wyrazu wolnego, który był obecny we wszystkich regresjach w tym rozdziale.
} 
delu 3.1.2.5), natomiast dwie pozostałe zmienne wyznaczono na podstawie danych o pracujących (lub ludności) i nakładach brutto na środki trwałe (z okresu 1995-2010), czego wyniki znajdują się w tabeli 3.2.1.1.

Tabela 3.2.1.1. Wartości wybranych zmiennych (zróżnicowanych regionalnie) w modelu Solowa (średnia dla lat 1995-2010)

\begin{tabular}{|l|c|c|c|}
\hline \multicolumn{1}{|c|}{ Województwo } & $\begin{array}{c}\text { Średnie tempo wzro- } \\
\text { stu ludności } \boldsymbol{n}_{\mathbf{i}}\end{array}$ & $\begin{array}{c}\text { Średnie tempo wzro- } \\
\text { stu pracujących } \boldsymbol{n}_{\mathbf{i} 2}\end{array}$ & $\begin{array}{c}\text { Średnia stopa inwe- } \\
\text { stycji } \boldsymbol{s}_{\boldsymbol{i}}\end{array}$ \\
\hline dolnośląskie & $-0,3 \%$ & $0,3 \%$ & $24 \%$ \\
\hline kujawsko-pomorskie & $-0,1 \%$ & $0,4 \%$ & $20 \%$ \\
\hline lubelskie & $-0,3 \%$ & $-0,3 \%$ & $20 \%$ \\
\hline lubuskie & $-0,1 \%$ & $0,1 \%$ & $23 \%$ \\
\hline tódzkie & $-0,4 \%$ & $1,4 \%$ & $21 \%$ \\
\hline małopolskie & $0,2 \%$ & $0,6 \%$ & $24 \%$ \\
\hline mazowieckie & $0,2 \%$ & $-0,2 \%$ & $28 \%$ \\
\hline opolskie & $-0,5 \%$ & $0,9 \%$ & $22 \%$ \\
\hline podkarpackie & $-0,1 \%$ & $-1,2 \%$ & $23 \%$ \\
\hline podlaskie & $-0,2 \%$ & $0,2 \%$ & $23 \%$ \\
\hline pomorskie & $0,2 \%$ & $-0,4 \%$ & $24 \%$ \\
\hline śląskie & $-0,4 \%$ & $0,5 \%$ & $20 \%$ \\
\hline świętokrzyskie & $-0,4 \%$ & $0,5 \%$ & $22 \%$ \\
\hline warmińsko-mazurskie & $-0,2 \%$ & $0,1 \%$ & $22 \%$ \\
\hline wielkopolskie & $0,1 \%$ & $1,2 \%$ & $24 \%$ \\
\hline zachodniopomorskie & $-0,2 \%$ & $0,1 \%$ & $22 \%$ \\
\hline
\end{tabular}

Źródło: obliczenia własne

Przy przyjęciu powyższych założeń, oszacowania modelu wzrostu Solowa postaci (2.1.1.6) są następujące:

(3.2.1.3a)

$$
\mathrm{R}^{2}=0,61
$$

$\ln \left(\frac{P K B_{-} p c_{i, 2010}}{P K B_{-} p c_{i, 1995}}\right)=0,07 \ln \left(P K B_{-} p c_{i, 1995}\right)+1,12^{* * * *} \ln \left(s_{i}\right)-0,53 \ln \left(n_{i 1}+g+\delta\right)$

$\mathrm{R}^{2}=0,66$

$\ln \left(\frac{W D B_{-} p p_{i, 2010}}{W D B_{-} p p_{i, 1995}}\right)=0,04 \ln \left(W D B_{-} p p_{i, 1995}\right)+1,14^{* * * *} \ln \left(s_{i}\right)-0,68^{* * *} \ln \left(n_{i 2}+g+\delta\right)$

W powyższych oszacowaniach estymatory parametrów mają poprawne znaki (należało oczekiwać dodatniego znaku przy stopie inwestycji i ujemnego przy tempie wzrostu pracujących/ludności ${ }^{25}$ - por. np. Próchniak [2011, s. 183]), które sugerują dodatni wpływ stopy inwestycji na wzrost gospodarczy (który jednakże wydaje się nieco przeszacowany) i ujemny wpływ $n_{i}$ (który dodatkowo w równaniu dla PKB jest nieistotny statystycznie). Jeśli chodzi o wnioski odnośnie do konwergencji, to nieistotność statystyczna parametrów przy PKB_pc 1995

${ }^{25}$ Ponieważ parametry $g$ i $\delta$ nie różniły się pomiędzy regionami, mówimy głównie o wpływie $n_{i}$. 
oraz WDB_pp 1995 nie pozwala potwierdzić ani konwergencji, ani dywergencji. Gdyby zignorować test istotności, to można mówić o dywergencji PKB per capita, z tempem rozbieżności rzędu $0,44 \%$ i konwergencji wydajności pracy $\mathrm{z}$ tempem zbieżności rzędu $0,24 \%$ rocznie ${ }^{26}$. Uwzględnienie specyficznych dla regionów czynników warunkujących ich wzrost gospodarczy pozwoliło po pierwsze, znacznie lepiej opisać to zjawisko (o czym świadczą znacznie wyższe, niż w regresjach 3.2.1.1a-3.2.1.1b, wartości $\mathrm{R}^{2}$ ), a po drugie osłabiło procesy dywergencyjne ${ }^{27}$.

Ostatecznym wnioskiem z przeprowadzonych badań jest brak (beta) konwergencji w wojewódzkich PKB per capita i WDB na pracującego zarówno w ujęciu absolutnym, jak i warunkowym ${ }^{28}$. Taki wniosek należy wysnuć dla pełnej grupy 16 województw Polski. Na wykresach 3.2.1a-3.2.1b uwidacznia się jednakże luka pomiędzy punktami reprezentującymi grupę województw o niższych i wyższych wartościach początkowych badanego zjawiska (oś pozioma dla PKB per capita lub WDB na pracującego w 1995 roku). Może to sugerować, że w bardziej homogenicznych grupach województw (klubach) procesy konwergencji wyglądają inaczej niż dla całej próby 16 województw ${ }^{29}$. Dlatego na koniec tego rozdziału przeprowadzono doświadczenie polegające na oszacowaniu równań beta-konwergencji absolutnej w podziale na grupy województw (o podziale tym pisano pod koniec podrozdziału 3.1.1) - por. tabela 3.2.1.2.

Tabela 3.2.1.2. Estymatory parametru przy zmiennej objaśniającej w równaniach typu (3.2.1.1a) - (3.2.1.1b) i podziale województw na podgrupy (por. p. 3.1.1)

\begin{tabular}{|l|c|c|}
\hline Grupa województw & Równanie (3.2.1.1a) & Równanie (3.2.1.1b) \\
\hline 16 województw & $+0,28$ & $+0,04$ \\
\hline 15 woj. (bez mazow.) & $-0,01$ & $-0,07$ \\
\hline 5 najbiedniejszych & $+0,55$ & $-0,47$ \\
\hline 5 średnich & $-1,49^{* * *}$ & $-0,89^{* *}$ \\
\hline 5 najbogatszych & $-0,54$ & $-0,74^{* *}$ \\
\hline
\end{tabular}

Źródło: obliczenia własne

\footnotetext{
${ }^{26}$ Wartości te są jednak tak niskie, że policzony na ich podstawie czas, który potrzebny byłby aby zmniejszyć istniejące różnice o połowę (tzw. half-life) jest mierzony setkach lat.

${ }^{27} \mathrm{~W}$ obu równaniach uwzględnienie specyficznych dla województw temp wzrostu TFP (w postaci zróżnicowanych regionalnie parametrów $g_{i}$ ), jeszcze bardziej zwiększa dopasowanie modelu do danych oraz pozwala wnioskować o niższym tempie rozbieżności PKB per capita $(0,29 \%$ rocznie) i wyższym (choć wciąż nieistotnym statystycznie) tempie zbieżności wydajności pracy $(0,56 \%)$.

${ }^{28}$ Do tak ostrożnego wniosku skłania nieistotność parametrów przy początkowej wartości PKB per capita lub WDB na pracującego w regresjach (3.2.1.1a)-(3.2.1.3b). Jedynie w równaniu betakonwergencji absolutnej dla PKB per capita można było potwierdzić dywergencję dla $15 \%$ poziomu istotności, co przekładało się na tempo rozbieżności rzędu 1,6\% rocznie.

${ }^{29}$ Co nawiązuje do koncepcji konwergencji globalnej i lokalnej - klubowej (por. Durlauf i Johnson [1995], Galor [1996]).
} 
Z powyższej tabeli wynika ${ }^{30}$, że już samo wyeliminowanie $\mathrm{z}$ analiz województwa mazowieckiego wystarcza, aby województwa wykazały słabą (nieistotną statystycznie) konwergencję pod względem obu badanych zmiennych. W grupach województw o podobnym poziomie zamożności konwergencja jest jeszcze bardziej widoczna. Najbardziej - wśród grupy województw o średnim poziomie zamożności (współczynnik regresji rzędu $b=-1,49$ wskazuje, że tempa wzrostu w tej grupie były tak wysokie, ze mogło dojść do zmiany uporządkowania województw w tej grupie pod względem PKB per capita - por. p. 3.2.3). Generalnie, co wynikało również z poprzednich badań, procesy konwergencyjne są bardziej charakterystyczne dla wydajności pracy niż PKB per capita. Jest to argument, aby nie traktować tych indykatorów aktywności gospodarczej zamiennie.

\subsubsection{Sigma-konwergencja}

Zgodnie z uwagami z rozdziału 2 (por. podrozdział 2.2.3), konwergencja typu beta jest warunkiem koniecznym do wystąpienia konwergencji sigma $\mathrm{w}$ badaniach z rozdziału 3.2.1 warunek ten nie jest spełniony dla wojewódzkich PKB per capita (w żadnej wersji modelu dla 16 województw). Niemniej dla pewnego porządku oraz ukazania różnic w kształtowaniu się zróżnicowania wśród województw pod względem obu wskaźników - przeprowadzono analizy sigma-konwergencji zarówno dla PKB per capita jak i WDB na pracującego.

$\mathrm{Na}$ wykresach 3.2.2.1a-3.2.2.12b znajdują się różne miary zróżnicowania dla badanych zmiennych ${ }^{31}$. Wykresy te pokazują, że w przypadku PKB per capita zróżnicowanie rośnie w całym analizowanym okresie. W przypadku WDB na pracującego zróżnicowanie rosło do $2000 \mathrm{r}$. i od tego czasu utrzymuje się na względnie stałym poziomie. W związku z brakiem malejącej tendencji w dyspersji wojewódzkich PKB pc. i WDB pp., zastosowanie testów prezentowanych $\mathrm{w}$ rozdziale 2.2 .2 ma służyć weryfikacji istotności hipotezy o sigmadywergencji (zamiast sigma-konwergencji). Weryfikacja hipotez testów (2.2.2.1) - (2.2.2.3) oraz analiza istotności trendu wskazuje, że zarówno PKB per capita, jak i wydajność pracy wykazują istotną statystycznie sigmadywergencję.

\footnotetext{
${ }^{30}$ Do wyników z tabeli 3.2.1.2 należy jednakże podchodzić z ostrożnością, bowiem regresje dla grup województw charakteryzują się niewielką liczbą stopni swobody - dlatego nie oszacowano regresji typu (3.3.1.2a)-(3.3.1.3b) - o większej liczbie zmiennych objaśniających.

${ }^{31}$ Ukazany na wykresach współczynnik zmienności $V$ jest liczony wg formuły (2.2.1.2), odchylenie standardowe logarytmów $l S$ według (2.2.1.3), współczynnik zmienności wykorzystujący odchylenie średnie - według (2.2.1.5), a współczynnik Giniego - $G$-obliczono na podstawie wzoru (2.2.1.9).
} 
Wykres 3.2.2.1a. Nierówności w PKB per capita według różnych miar zróżnicowania i koncentracji

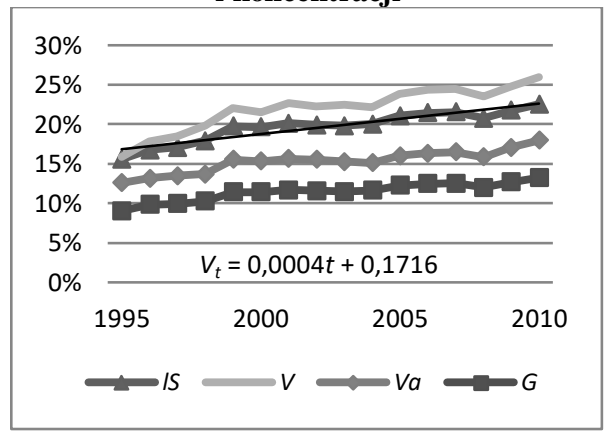

Wykres 3.2.2.1b. Nierówności WDB na pracującego według różnych miar zróżnicowania i koncentracji

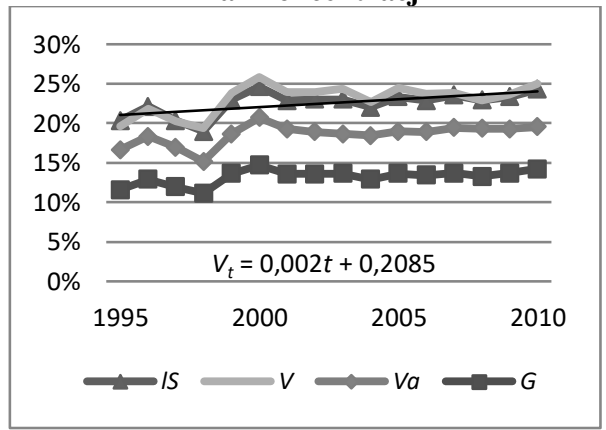

Źródło: opracowanie własne

Stosunkowo duża odległość pomiędzy współczynnikiem zmienności zmierzonym za pomocą odchylenia standardowego $(V)$, a współczynnikiem zmienności wykorzystującym odchylenie średnie $\left(V_{a}\right)$ świadczy o występowaniu obserwacji nietypowych - taką obserwacją są dane dla województwa mazowieckiego ${ }^{32}$. Choć nie tylko mazowieckiego - duże dysproporcje dotyczą również województw najbogatszych i najuboższych: w latach analizy udział gospodarek pięciu najbogatszych regionów Polski rósł, podczas gdy udział pięciu najuboższych regionów Polski Wschodniej - malał.

W celu ukazania różnic w różnych grupach województw wykorzystano dekompozycję współczynnika Thaila daną wzorem (2.2.1.8). Na poniższych wykresach pokazano jaka część współczynnika Thaila $(T)$ jest kwestią zróżnicowania pomiędzy grupami $\left(T_{g}\right)$, a jaka pomiędzy województwami w grupach $\left(T_{r}\right)$. Do grupy najbogatszych województw włączono najpierw (na wykresach 3.2.2.2a 3.2.2.2b) województwo mazowieckie (które zaliczone zostało do grupy województw najbogatszych).

\footnotetext{
${ }^{32}$ Należy jednocześnie zauważyć, że różnice te są mniejsze w przypadku WDB na pracującego co pokazuje występowanie większego efektu aglomeracyjnego w PKB per capita (por. p. 1.3.1).
} 
Wykres 3.2.2.2a. Dekompozycja współczynnika Thaila dla PKB per capita $w$ podziale na 3 grupy województw

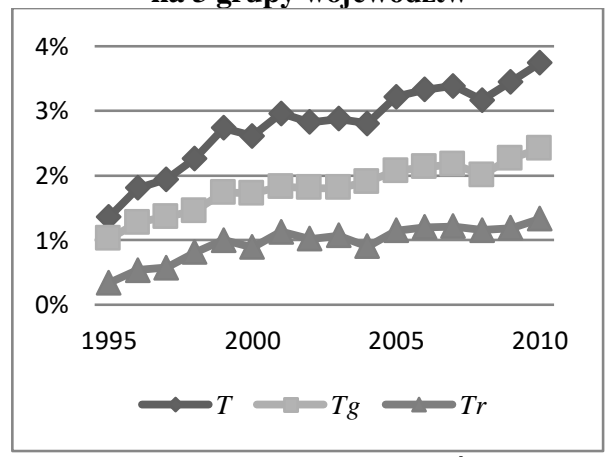

Wykres 3.2.2.2b. Dekompozycja współczynnika Thaila dla WDB na pracującegow podziale na 3 grupy województw

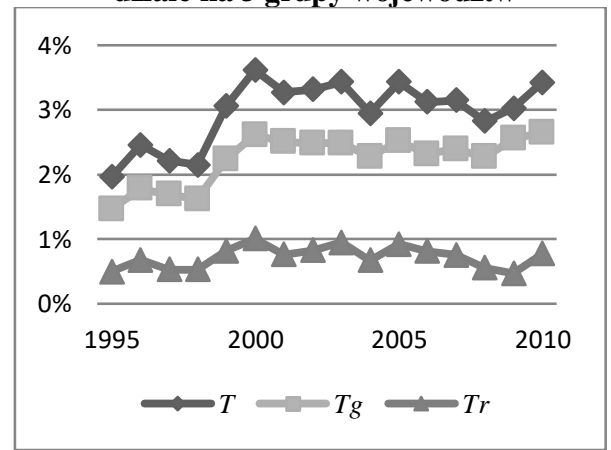

Źródło: opracowanie własne

Dzięki dekompozycji Thaila można stwierdzić, że na ogólne zróżnicowanie województw mierzone współczynnikiem Thaila $(T)$ składa się przede wszystkim zróżnicowanie pomiędzy grupami województw $\left(T_{g}\right)$, a w mniejszym stopniu zróżnicowanie wewnątrz tych grup $\left(T_{r}\right)$. Okazuje się (czego nie widać na wykresach, ale wynika z dodatkowych obliczeń), że za duże zróżnicowanie międzygrupowe $\left(T_{g}\right)$ odpowiada głównie grupa województw najbogatszych, której częścią jest województwo mazowieckie. Jeśli wyłączy się to województwo (przyjmując, że tworzy ono osobną, czwartą, grupę), to wykresy 3.2.2.2a3.2.2.2b będą wyglądały zgoła odmiennie - por. 3.2.2.3a-3.2.23b.

Wykres 3.2.2.3a. Dekompozycja wspólczynnika Thaila dla PKB per capita i 4 grup województw

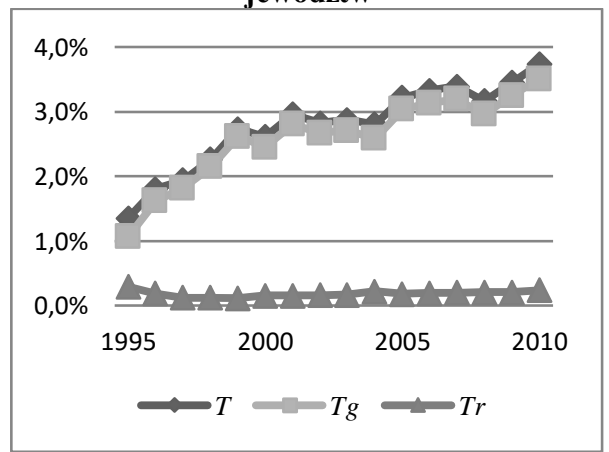

Wykres 3.2.2.3a. Dekompozycja współczynnika Thaila dla WDB na pracującego i 4 grup województw

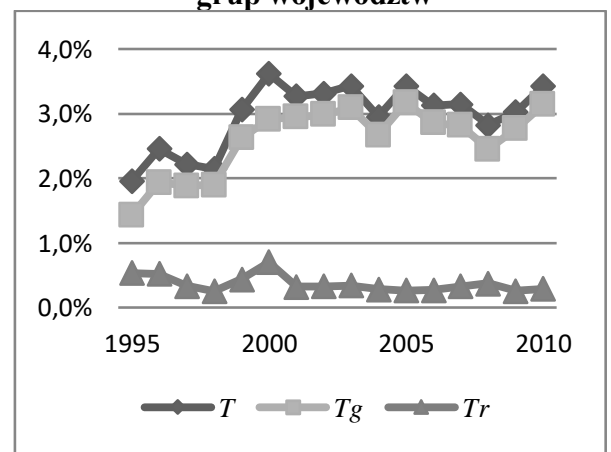

Źródło: opracowanie własne 
$\mathrm{Z}$ wykresów 3.2.2.3a-3.2.2.3b wynika, że właściwie całość zróżnicowania jest wynikiem zróżnicowania międzygrupowego, a dokładnie (czego nie widać na wykresach, lecz wynika z obliczeń) zróżnicowania pomiędzy województwem mazowieckim a resztą grup.

Ostatecznie, różnice pomiędzy zróżnicowaniem województw w danej grupie i pomiędzy grupami sugerują że pomimo, że brak jest sigma-konwergencji dla wszystkich 16 województw, to może ona zachodzić w bardziej homogenicznych klastrach, jakie tworzą województwa uszeregowane według zamożności - por. wykresy 3.2.2.4a-3.2.2.4b.

Wykres 3.2.2.4a. Współczynnik zmienności PKB per capita dla grup województw

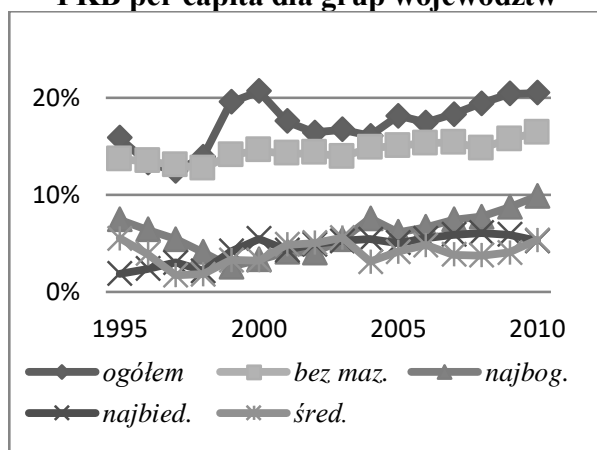

Wykres 3.2.2.4b. Współczynnik zmienności PKB per capita dla grup województw

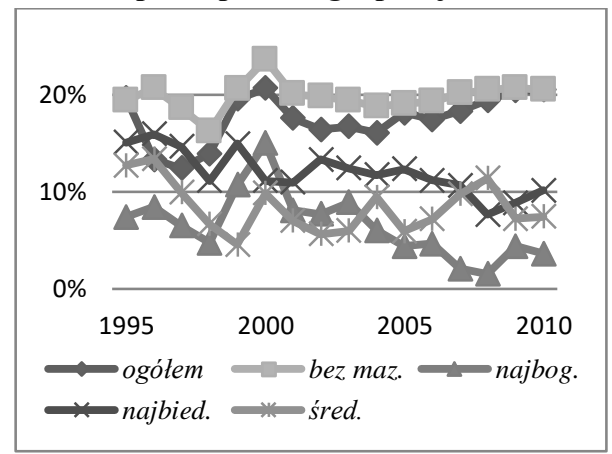

Źródło: opracowanie własne

Z powyższych wykresów wynika, że dla $\mathrm{PKB}$ per capita brak jest sigma-konwergencji bez względu na pogrupowanie województw. Inaczej jest w przypadku WDB na pracującego, dla którego to wskaźnika można zaobserwować spadek zróżnicowania: najsilniejszy w grupie województw najbogatszych (bez mazowieckiego), następnie w grupie województw o średnim poziomie zamożności. Niemniej dla wszystkich 3 grup zamożności (województw najbogatszych, najbiedniejszych i średnich) można wykazać (na podstawie statystyk 2.2.2.12.2.2.4) występowanie sigma-konwergencji wydajności pracy, w przeciwieństwie do PKB per capita.

Fakty te potwierdzają, że homogeniczność grupy ma ogromny wpływ na wnioski co do konwergencji, że znacznie łatwiej ją osiągnąć w mniejszych, jednorodnych klastrach oraz że badania konwergencji na podstawie PKB per capita i WDB na pracującego nie powinny być traktowane zamiennie. 


\subsubsection{Gamma-konwergencja}

W sytuacji, gdy można wykazać, że wśród badanych regionów występuje betakonwergencja i sigma-dywergencja (jak w przypadku PKB per capita $\mathrm{w}$ grupach województw podzielonych pod względem zamożności) rozstrzygającym testem może być weryfikacja hipotezy o gamma-konwergencji. Występowanie gamma-konwergencji thumaczy, dlaczego proces doganiania odbywa się czasami przy jednoczesnym zwiększeniu zróżnicowania badanych obszarów. Zjawisko takie nazywane jest w literaturze jako leapfrogging i oznacza zamianę pozycji badanych obszarów w rankingu pod względem badanej cechy (tempa wzrostu początkowo biedniejszych obszarów są tak duże, że wyprzedzają one w rankingu bogatsze). Aby stwierdzić, czy tak się stało stosuje się współczynnik konkordancji rang i testy gamma-konwergencji opisane w podrozdziale 2.3. W przypadku badania PKB per capita i WDB na pracującego, dla których nie uzyskano globalnej (tzn. dla wszystkich 16 województw) ani beta, ani sigmakonwergencji nie należy spodziewać się również gamma-konwergencji. Niemniej dla pewnego porządku zbadano ten rodzaj wodniesieniu do tych zmiennych.

Na poniższych wykresach pokazano kształtowanie się współczynnika konkordancji rang Kendalla wyliczonego według wzoru (2.3.2.1).

Wykres 3.2.3.1a. Współczynniki konkordancji rang Kendalla dla PKP per capita

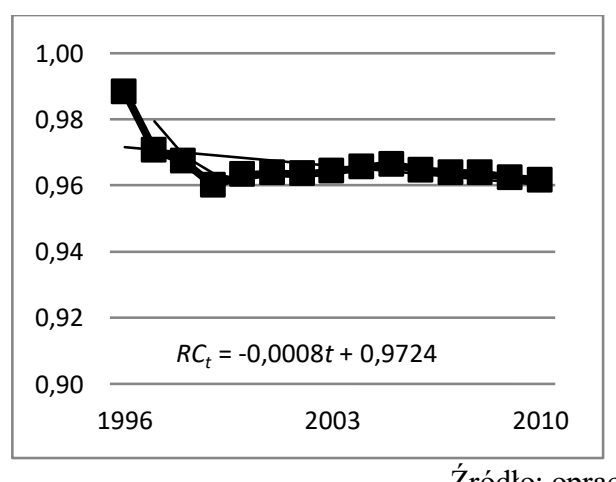

Źródło: opracowanie własne
Wykres 3.2.3.1b. Wspólczynniki konkordancji rang Kendalla dla WDB na pracują-

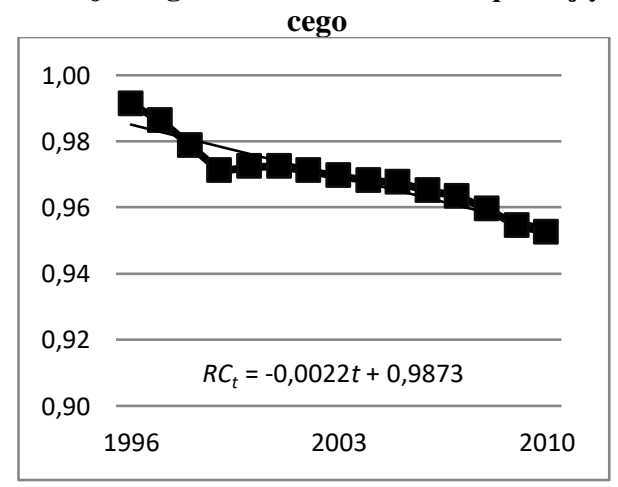

Zgodnie z modyfikacjami testów gamma-konwergencji zaproponowanymi w podrozdziale 2.3.2 ujemny i istotny statystycznie współczynnik w liniowej funkcji trendu jest warunkiem wstępnym do dalszego badania tego rodzaju konwergencji. Ten warunek jest spełniony jedynie dla wydajności pracy (dla PKB per capita współczynnik trendu jest ujemny, lecz nieistotny statystycznie). Dla tej zmiennej obliczono statystykę $(2.3 .1 .3)$, której wartość $\left(\chi^{2}=214\right)$ znacz- 
nie przekroczyła wartość krytyczną, co pozwoliło na wniosek o braku gammakonwergencji. Ponieważ, jak pisano w rozdziale 2.3.1, przy weryfikacji hipotezy o braku gamma-konwergencji za pomocą statystyki (2.3.1.3) istnieje prawdopodobieństwo popełnienia błędu pierwszego rodzaju, zastosowano również testy postaci (2.3.2.4) i (2.3.2.5), które potwierdziły, wcześniejszy wniosek (o braku gamma-konwergencji). Oznacza to, że nie doszło do istotnej statystycznie zmiany rang województw pod względem PKB per capita i WDB na pracującego - brak jest zatem gamma-konwergencji w ujęciu globalnym (tzn. badania wszystkich 16 województ).

Jeśli chodzi o węższe grupy województw, to zestawienie wyników z tabeli 3.2.1.2 oraz wykresów 3.2.2.4a-3.2.2.4b, pokazuje, że wewnątrz niektórych grup mogło dojść do istotnej zmiany rang (leapfrogging) województw pod względem analizowanych zmiennych. Przesłanką do badania tego faktu jest istnienie beta-konwergencji i brak sigma-konwergencji w grupie województw o średnim poziomie zamożności pod względem obu wskaźników (PKB per capita i WDB na pracującego) $)^{33}$, jak i niższy od -1 współczynnik regresji betakonwergencji dla PKB per capita (por. wartość -1,49 w tabeli 3.2.1.2). Poniżej pokazano kształtowanie się współczynnika konkordancji rang Kendalla policzonego wg wzoru (2.3.2.1).

Wykres 3.2.3.2a. Wspólczynniki konkordancji rang Kendalla dla PKP per capita w grupie województw o średnim poziomie zamożności

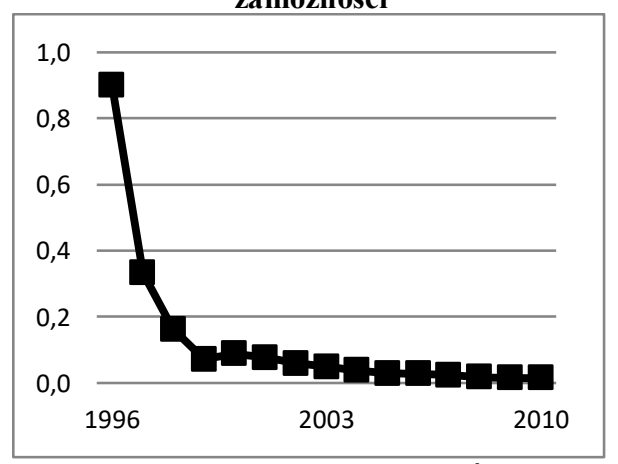

Wykres 3.2.3.2b. Współczynniki konkordancji rang Kendalla dla WDB na pracującego w grupie województw o średnim poziomie zamożności

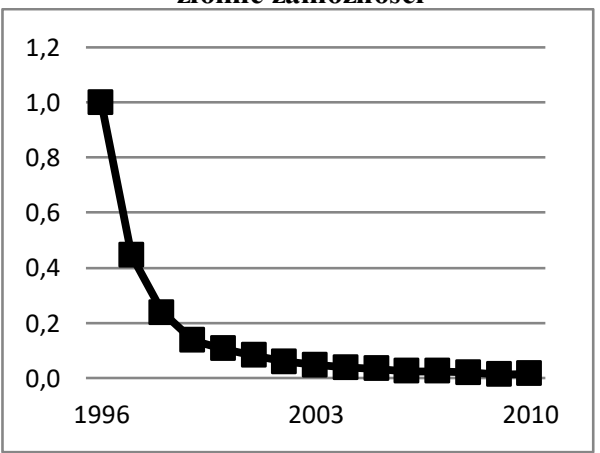

Źródło: obliczenia własne

Spadek zróżnicowania współczynnika konkordancji rang Kendalla jest tak silny, że należy oczekiwać, że wszystkie proponowane w rozdziale 2.3.2- 2.3.3 statystyki będą wskazywać na występowanie gamma-konwergencji. I tak jest

\footnotetext{
${ }^{33}$ Istotna statystycznie beta-konwergencja występuje również w grupie województw najbogatszych pod względem wydajności pracy, lecz dla tej grupy uzyskano również istotną sigmakonwergencję - nie ma zatem podstaw do przypuszczeń, że doszło do zamiany rang.
} 
w istocie: zastosowanie wzorów (2.3.2.4), (2.3.2.5), ale również (2.3.1.3)(2.3.1.4) daje wartości statystyk pozwalających stwierdzić, że uporządkowanie województw o średnim poziomie zamożności istotnie się zmieniło na przestrzeni lat $1995-2010^{34}$. Dla grupy województw o średnim poziomie zamożności można stwierdzić występowanie gamma-konwergencji PKB per capita i WDB na pracującego.

\subsubsection{Konwergencja stochastyczna}

Stosunkowo niewielka liczebność wewnątrz poszczególnych grup (czy inaczej mówiąc klubów, czy klastrów - nawiązując do koncepcji konwergencji klubowej) umożliwia przeprowadzenie testu konwergencji stochastycznej (co nie jest możliwe dla całej próby 16 województw, bowiem liczba obserwacji nie pozwala na stworzenie odpowiedniego modelu $\mathrm{VECM}^{35}$ ). Wyniki badania konwergencji stochastycznej dla PKB pc. oraz WDB pp. pokazują poniższe tabele ${ }^{36}$.

Tabela 3.2.4.1. Wyniki testu na ko integrację PKB per capita w grupach województw

\begin{tabular}{|c|c|c|c|c|c|}
\hline $\begin{array}{c}\text { Rząd } \\
\pi\end{array}$ & $\begin{array}{c}\text { Wartość } \\
\text { wlasna }\end{array}$ & $\begin{array}{c}\text { Statystyka } \\
\text { testu } \lambda_{\text {tr }}\end{array}$ & $\begin{array}{c}\text { Wartość p } \\
\text { dla } \lambda_{\text {tr }}\end{array}$ & $\begin{array}{c}\text { Statystyka } \\
\text { testu } \lambda_{\max }\end{array}$ & $\begin{array}{l}\text { Wartość } \\
\text { p dla } \lambda_{\max }\end{array}$ \\
\hline \multicolumn{6}{|c|}{ Województwa najbiedniejsze (lubelskie, podlaskie, podkarpackie, świętokrzyskie, warm.-maz.) } \\
\hline 0 & 0,988 & 112,30 & {$[0,0003]$} & 66,419 & {$[0,0000]$} \\
\hline 1 & 0,812 & 45,88 & {$[0,6083]$} & 25,086 & {$[0,2926]$} \\
\hline 2 & 0,577 & 20,79 & {$[0,9390]$} & 12,919 & {$[0,8081]$} \\
\hline 3 & 0,296 & 7,876 & {$[0,9787]$} & 5,2748 & {$[0,9701]$} \\
\hline 4 & 0,159 & 2,601 & {$[0,9064]$} & 2,6018 & {$[0,9077]$} \\
\hline \multicolumn{6}{|c|}{ Województwa najbogatsze (dolnośląskie, śląskie, wielkopolskie, pomorskie, zachodniopom.) } \\
\hline 0 & 0,915 & 104,84 & {$[0,0017]$} & 36,99 & {$[0,0678]$} \\
\hline 1 & 0,888 & 67,84 & {$[0,0205]$} & 32,85 & {$[0,0369]$} \\
\hline 2 & 0,666 & 35,00 & {$[0,2486]$} & 16,44 & {$[0,5201]$} \\
\hline 3 & 0,533 & 18,55 & {$[0,3142]$} & 11,42 & {$[0,4834]$} \\
\hline 4 & 0,379 & 7,13 & {$[0,3400]$} & 7,14 & {$[0,3406]$} \\
\hline \multicolumn{6}{|c|}{ Województwa średnie (opolskie, łódzkie, małopolskie, kujawsko-pomorskie, lubuskie) } \\
\hline 0 & 0,994 & 145,15 & {$[0,0000]$} & 77,39 & {$[0,0000]$} \\
\hline 1 & 0,891 & 67,75 & {$[0,0209]$} & 33,19 & {$[0,0331]$} \\
\hline 2 & 0,773 & 34,57 & {$[0,2670]$} & 22,23 & {$[0,1417]$} \\
\hline 3 & 0,473 & 12,34 & {$[0,7868]$} & 9,62 & {$[0,6649]$} \\
\hline 4 & 0,166 & 2,72 & {$[0,8947]$} & 2,72 & {$[0,8961]$} \\
\hline
\end{tabular}

Źródło: obliczenia własne

\footnotetext{
${ }^{34}$ Statystyki (2.3.1.3) i (2.3.1.4) wynoszą odpowiednio 3,5 oraz 6,0 - obie są mniejsze od wartości krytycznej testu $\lambda^{2}$, co nie pozwala na odrzucenie hipotezy zerowej o występowaniu gammakonwergencji.

${ }^{35}$ Nawet wyłączenie jednego z województw, lub analiza danych przekształconych jako odchylenia od obszaru referencyjnego nie pozwala, przy 16 obserwacjach rocznych, na estymację VECM dla wszystkich 16 województw.

${ }^{36}$ Rodzaj procesów generujących badane zmienne sugeruje wybór postaci VECM z tzw. ograniczonym trendem.
} 
Tabela 3.2.4.2. Wyniki testu na kointegrację WDB na pracującego $w$ grupach województw

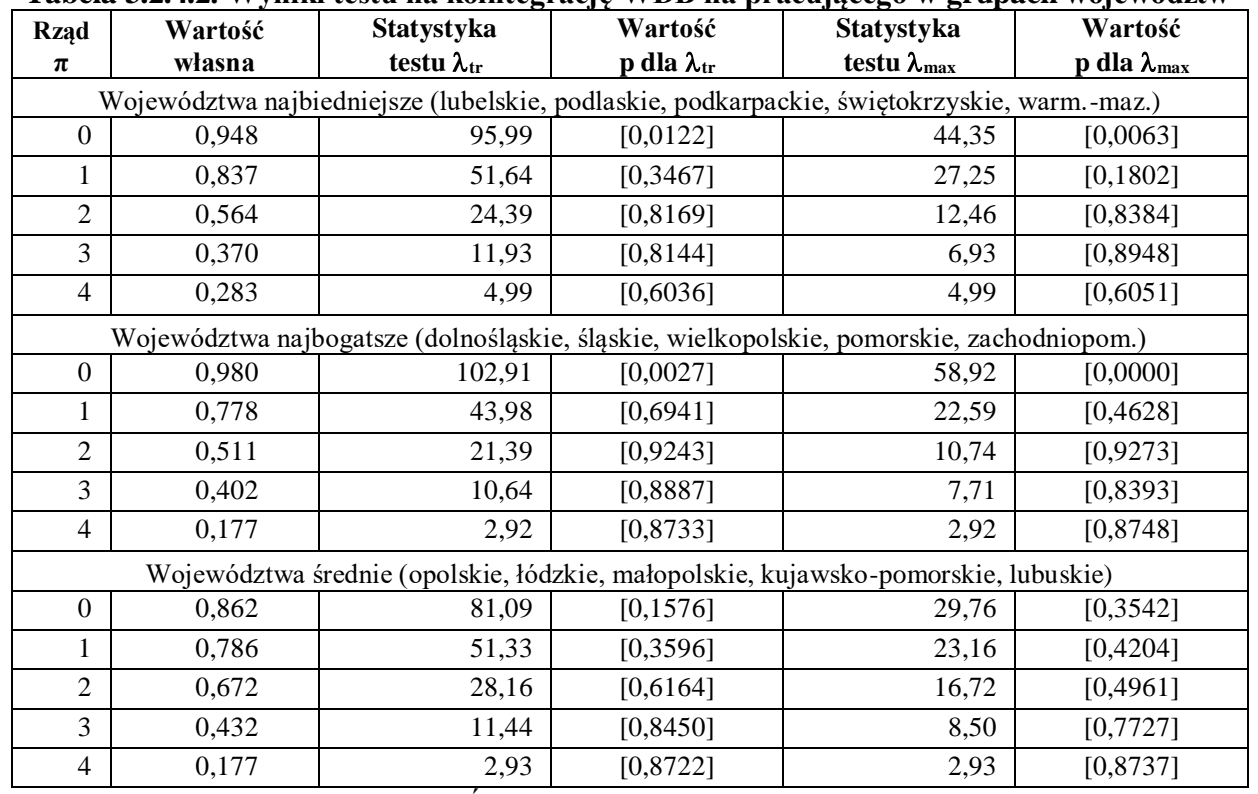

Źródło: obliczenia własne

W powyższych tabelach zaprezentowano statystyki obliczane wg wzorów 2.4.4.1 i 2.4.4.2. Testują one występowanie 0,1 lub więcej wektorów kointegracyjnych (na podstawie ich istnienia wnioskuje się o konwergencji - kointegracji stochastycznej) ${ }^{37}$.

Z powyższych tabel wynika, że można stwierdzić istnienie co najmniej 1 wektora kointegracyjnego dla PKB per capita we wszystkich grupach województw (nawet najbiedniejszych, dla których uzyskano brak beta- i sigma-konwergencji $\left.{ }^{38}\right)$.

Jeśli chodzi o WDB na pracującego to wyniki testów na kointegrację (a więc i konwergencję stochastyczną) pokazują, że występuje ona wśród województw najbiedniejszych i najbogatszych (ale nie dla województw o średnim poziomie zamożności, dla których uzyskano istotną statystycznie beta- i sigmakonwergencję, co jest wynikiem zaskakującym).

\footnotetext{
${ }^{37}$ Pierwsza statystyka służy do testowania hipotezy zerowej, że liczba różnych od siebie wektorów kontegracyjnych jest mniejsza lub równa $r$. Druga statystyka służy do testowania hipotezy zerowej, że liczba wektorów kointegracyjnych wynosi $r$ przeciwko hipotezie alternatywnej, że jest ich $r+1$.

${ }^{38} \mathrm{Co}$ oznacza, że pomimo braku efektu doganiania w tej grupie, województwa te dążą do wspólnego punktu równowagi.
} 


\subsection{Konwergencja TFP i stany równowagi wojewódzkiej}

W celu zweryfikowania hipotezy o konwergencji technologicznej (TFPkonwergencji) należało oszacować wartości TFP w poszczególnych województwach, czego dokonano za pomocą wzoru (3.1.2.1), który, w przypadku stosowania go dla poszczególnych regionów, miał postać:

$$
T F P_{i t}=\frac{Y_{i t}}{K_{i t}^{\alpha_{i}} L_{i t}^{\left(1-\alpha_{i}\right)}}
$$

gdzie:

$T F P_{i t}$ - łączna produktywność czynników produkcji w roku $t$, regionie $i$;

$K_{i t}$ - wartość brutto środków trwałych w cenach stałych w roku $t$, regionie $i$;

$L_{i t}$ - liczba pracujących w roku $t$, regionie $i$;

$Y_{i t}$ - wartość dodana brutto w cenach stałych w roku $t$, regionie $i$;

$\alpha_{i}$ - elastyczność produkcji względem kapitału w regionie $i$;

$t=1995, \ldots, 2010, i=1, \ldots, 16$.

Do oszacowania regionalnych wartości $T F P$ użyto dwóch różnych założeń co do elastyczności produkcji względem kapitału $-\alpha^{39}$ :

a) $T F P_{a}$ - dla takiej samej we wszystkich województwach elastyczności produkcji względem kapitału: $\alpha=0,57$ (por. p. 3.1.2.2),

b) $T F P_{b}$ - dla zróżnicowanej w województwach wartości elastyczności produkcji względem kapitału $\alpha_{i}$ na poziomie wartości z ostatniej kolumny tabeli (3.1.2.1).

\footnotetext{
${ }^{39} \mathrm{~W}$ istocie policzono TFP na wiele innych jeszcze sposobów: różnicując miarę kapitału (wyliczając go przy pomocy formuły (1.2.2), gdzie używano różnych - stałych i zróżnicowanych wojewódzko stóp deprecjacji), używając różnych wartości elastyczności $\alpha$ z tabeli 3.1.2.2 oraz wyliczając ETFP (na podstawie wzoru 1.3.2.2.1). Wyniki wskazywały, że te różne założenia odnośnie do zmiennych i parametrów we wzorze (3.3.1) mają wpływ na szybkość konwergencji, która wahała się od $0,8 \%$ (dla efektywnej łącznej produktywności produkcji) do nawet 3,8\% rocznie (dla kapitału liczonego wg wzoru (1.2.2) i stałej we wszystkich województwach stopie deprecjacji $\delta=0,05$ i elastyczności $\alpha=0,5)$. Bardzo silny wpływ miało zróżnicowanie regionalne parametru $\alpha-$ im wyższe zróżnicowanie tego parametru pomiędzy województwami tym niższa szybkość zbieżności, a nawet - jej brak.
} 


\subsubsection{Beta konwergencja absolutna i warunkowa}

Oszacowanie równania beta-konwergencji postaci 2.1.1.1 dla TFP wyliczonego wg powyższych założeń pokazuje, że występuje ujemna zależność pomiędzy początkową wartością TFP w województwach, a tempem wzrostu tej zmiennej, co pokazują poniższe równania ${ }^{40} \mathrm{i}$ wykresy.

$$
\begin{aligned}
& \ln \left(\frac{T F P_{a i, 2010}}{T F P_{a i, 1995}}\right)=0,5^{* *}-0,22 \ln \left(T F P_{a i, 1995}\right), \mathrm{R}^{2}=0,08 \\
& \ln \left(\frac{T F P_{b i, 2010}}{T F P_{b i, 1995}}\right)=0,5^{* *}-0,20 \ln \left(T F P_{b i, 1995}\right), \mathrm{R}^{2}=0,11
\end{aligned}
$$

Wykres 3.3.1a. Beta-konwergencja absolutna wojewódzkich $T F P_{a}$

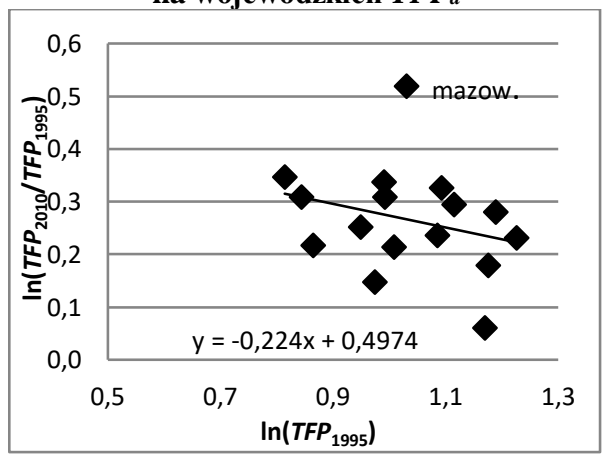

Wykres 3.3.1b. Beta-konwergencja absolutna wojewódzkich $T F P_{b}$

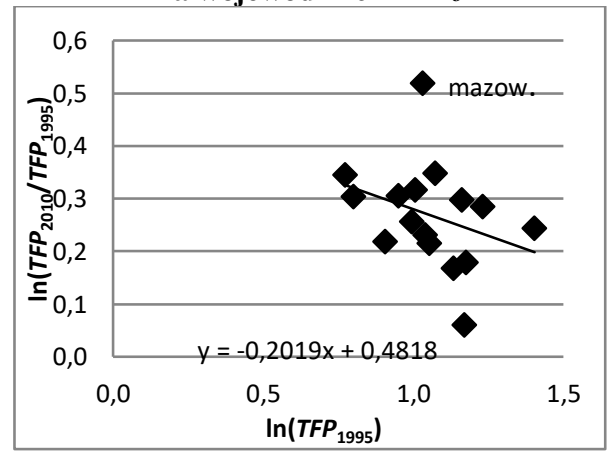

Źródło: obliczenia własne

$\mathrm{Z}$ równań (3.3.1.1a)- (3.3.1.1b) można wyliczyć szybkość zbieżności $T F P$, która wynosi $1,5-1,7 \%$ rocznie - jest niewielka (i nieistotna statystycznie), lecz dodatnia, co oznacza zbieżność, (a nie rozbieżność jak w przypadku PKB per capita i WDB na pracującego) wojewódzkich TFP. Taki wniosek wynika z modelu beta-konwergencji absolutnej, a poszerzenie równań (3.3.1.1a) - (3.3.1.2b) o specyficzne dla regionów czynniki TFP (czyli testowanie beta-konwergencji warunkowej) powinno zwiększyć tempo zbieżności (i zwiększyć $\mathrm{R}^{2}$ regresji).

W rozdziale 1.3.2.3 wskazano na różne sposoby endogenizacji TFP. Poniżej starano się zestawić tę wiedzę $\mathrm{z}$ możliwościami pozyskania odpowiednich danych statystycznych, które byłyby dostępne w całym analizowanym okresie oraz we wszystkich województwach Polski. Ostatecznie sformułowano następu-

40 Brak gwiazdek przy oszacowaniach oznacza, że empiryczny poziom istotności testu był mniejszy niż $p<0,15$. Jedna, dwie i trzy gwiazdki oznaczają, że współczynniki są istotne statystycznie przy poziomie istotności odpowiednio $p=0,15 ; 0,10 ; 0,05$. 
jący zestaw zmiennych, które były brane pod uwagę w próbach endogenizacji regionalnych TFP:

- intensywność inwestycji w B\&R (udział inwestycji na B\&R w nakładach brutto na środki trwałe)- $s_{i}$,

- tempo wzrostu kapitału B\&R (średnioroczne tempo wzrostu skumulowanych nakładów wewnętrznych na $\mathrm{B} \& \mathrm{R})-B R S_{i}$,

- tempo wzrostu udziału pracujących z wyższym wykształceniem- $w w_{i}$,

- tempo wzrostu współczynnika skolaryzacji osób w wieku 7-24 lata ${ }^{41}-G E$ $R_{i \cdot}{ }^{42}$

Powyższe zmienne dodawano do zestawu zmiennych objaśniających równania (3.3.1.1a)-(3.3.1.1b) i zestawiano na różne sposoby. Ostatecznie, jedyną (z powyżej wymienionych) zmienną, która była istotna statystycznie i znacznie podnosiła $\mathrm{R}^{2}$ równań, była intensywność inwestycji w B\&R- $s_{i}$ :

(3.3.1.2a) $\ln \left(\frac{T F P_{a i, 2010}}{T F P_{a i, 1995}}\right)=0,9^{* *}-0,27^{*} \ln \left(T F P_{a i, 1995}\right)+0,10^{* *} \ln \left(s_{i}\right), \mathrm{R}^{2}=0,42$

(3.3.1.2b) $\ln \left(\frac{T F P_{b i, 2010}}{T F P_{b i, 1995}}\right)=1,0^{* *}-0,27^{* * *} \ln \left(T F P_{b i, 1995}\right)+0,11^{* *} \ln \left(s_{i}\right), \mathrm{R}^{2}=0,53$

Uzupełnienie równania o udział inwestycji w B\&R spowodowało zwiększenie (co do modułu) oszacowania parametru przy początkowej wartości TFP (oraz jego istotność statystyczną), co oznacza wyższe tempo konwergencji TFP (teraz wynosi ono 2,1\% rocznie). Estymator przy $s_{i}$ pokazuje, że wzrost udziału inwestycji na B\&R (a dokładnie udziału nakładów wewnętrznych na B\&R w nakładach na środki trwałe ogółem regionu) zwiększa tempo wzrostu TFP (co jest zgodne z oczekiwaniami). A zatem, te regiony, które bardziej inwestują w postęp technologiczny (a przynajmniej w tę jego część, która może być ucieleśniona w środkach trwałych wynikających z ponoszenia wydatków na $B \& R$ por. p. 1.3.2.3) uzyskują wyższe tempo wzrostu postępu technologicznego.

Nie udało się, niestety, wprowadzić do równania efektów postępu technologicznego ucieleśnionego w kapitale ludzkim. Zmienna $G E R_{i}$ miała niepoprawny (ujemny) znak, a zmienna odzwierciedlająca akumulację pracujących z wyższym wykształceniem $-w w_{i}$ - pokazywała co prawda dodatni wpływ na tempo wzrostu $T F P$, lecz była nieistotna statystycznie. Można powiedzieć zatem, że próba endogenizacji TFP tylko częściowo się powiodła, lecz dzięki niej

\footnotetext{
${ }^{41}$ Sposób konstrukcji tego współczynnika dla województw Polski wyjaśniony został w pracy Kusideł [2013a].

${ }^{42}$ Wartości średnie wyliczono dla okresu 1995-2010.
} 
możliwe jest wnioskowanie o statystycznie istotnej konwergencji TFP wśród wszystkich województw Polski.

Na koniec, podobnie jak w rozdziale 3.2.1 dokonano podziału województw na grupy (kluby) i oszacowano dla nich równanie postaci (3.3.1.1a)- (3.3.1.1b). Wartości estymatorów przy zmiennej objaśniającej pokazuje tabela 3.3.1.1.

Tabela 3.3.1.1. Estymatory parametru przy zmiennej $\ln \left(T F P_{i 1995}\right)$ w równaniach typu (3.3.1.1a) - (3.3.1.1b) i podziale województw na podgrupy (por. p. 3.1.3)

\begin{tabular}{|l|c|c|}
\hline \multicolumn{1}{|c|}{ Grupa województw } & Równanie (3.3.1.1a) & Równanie (3.3.1.1b) \\
\hline 16 województw & $-0,22$ & $-0,20$ \\
\hline 15 woj. (bez mazow.) & $-0,22$ & $-0,18$ \\
\hline 5 najbiedniejszych & $-0,76^{* *}$ & $-0,43^{*}$ \\
\hline 5 średnich & $-0,85^{*}$ & $-0,85^{*}$ \\
\hline 5 najbogatszych & $-0,28$ & $-0,08$ \\
\hline
\end{tabular}

Źródło: obliczenia własne

Podział Polski na bardziej homogeniczne (pod względem zamożności) grupy województw spowodował, że tempo zbieżności TFP jest w większości grup wyższe niż wśród wszystkich 16 województw. Jest najwyższe w grupie województw o średnim poziomie zamożności (dla których $\beta=13 \%$, co oznacza, że dzisiejsze różnice technologiczne mogą być zredukowane o połowę w perspektywie zaledwie 5,5 roku). W drugiej kolejności są województwa Polski Wschodniej (najuboższe), dla których tempo zbieżności TFP wynosi do $10 \%$ rocznie. Wśród najbogatszych województw natomiast nie widać znacznego zwiększenie tempa konwergencji, w porównaniu do próby dla wszystkich województw Polski.

Spostrzeżenie to jest ważnym argumentem w sporze o konwergencję i dywergencję gospodarczą toczącym się na gruncie teorii ekonomicznych (por. 1.1 i 1.3.2). Zwolennicy teorii neoklasycznej i wynikającej z niej konwergencji, na poparcie tezy o mobilności i pewnej egzogeniczności postępu technologicznego stwierdzają, że po pierwsze zaawansowanie technologiczne uzbrojenia pracy w regionach najuboższych jest początkowo niskie (najpierw należy je nasycić kapitałem, potem technologią), po drugie, w warunkach zwiększania tego zaawansowania, można zawsze odpowiednie technologie imitować. Inaczej twierdzą zwolennicy teorii wzrostu endogenicznego argumentując, że luka technologiczna pomiędzy regionami wysoko i nisko rozwiniętymi jest zbyt duża, aby mogły ją pokonać kraje zacofane - jeśli nawet możliwe jest zastosowanie istniejących już technologii (zakładając nawet, że technologia jest mobilna) - to w praktyce tempo przejmowania nowych technologii zależy od zdolności absorpcyjnych kraju (regionu) naśladującego (którego otoczenie biznesu, struktury społeczne, uregulowania prawne mogą nie być gotowe, aby je przejąć). Im 
bardziej zaawansowana technologia tym trudniej ją przenosić - stąd wyższe tempo konwergencji wśród województw najbiedniejszych i średnich, zaś niższe wśród województw najbogatszych.

\subsubsection{Sigma-konwergencja}

Występowanie beta-konwergencji jest warunkiem koniecznym do wystąpienia innego jej rodzaju - konwergencji typu sigma. Warunek ten jest dla TFP jest spełniony, dlatego poniżej zbadano, czy efektowi doganiania towarzyszy również zmniejszanie dyspersji wojewódzkich TFP w czasie. W celu oceny tego faktu, poniżej umieszczono wykresy różnych miar zróżnicowania wojewódzkich TFP (wyliczonych wg wzorów (2.2.1.2), (2.2.1.3), (2.2.1.5), (2.2.1.9)) oraz dwóch wariantów elastyczności produkcji względem kapitału: stałej (na wykresach oznaczonych literą a) i zróżnicowanej w województwach elastyczności $\alpha_{i}$ (na wykresach oznaczonej literą b)

Wykres 3.3.2.1a. Nierówności w wojewódzkich TFPa według różnych miar zróżnicowania i koncentracji

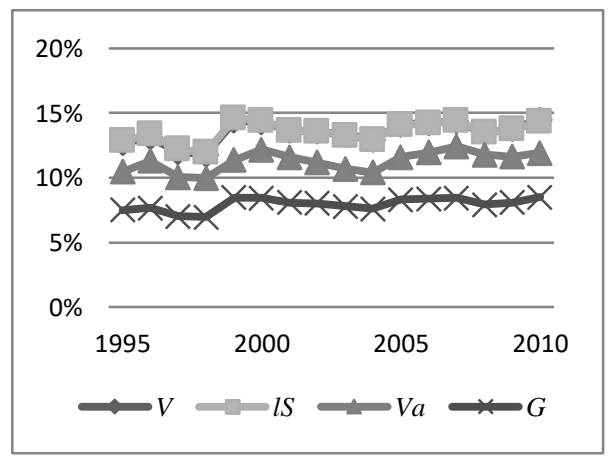

Wykres 3.2.3.1a. Nierówności w wojewódzkich $T F P_{b}$ według różnych miar zróżnicowania i koncentracji

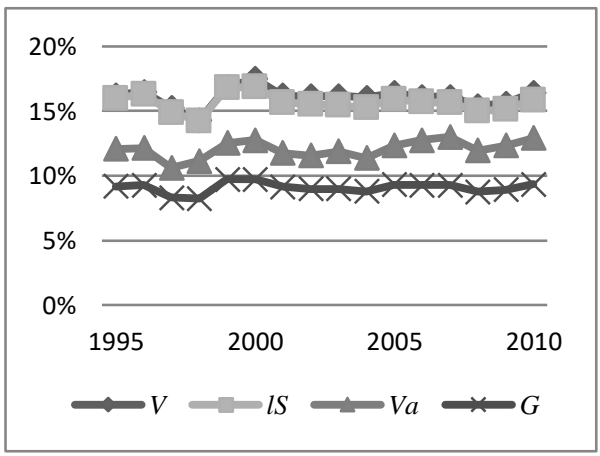

Źródło: opracowanie własne

Powyższe wykresy pokazują, że zróżnicowanie TFP nie spada (brak sigmakonwergencji) - jest ono względnie stałe w czasie (co oznacza również brak sigma-dywergencji), co formalnie potwierdzono za pomocą statystyk $T_{1}, T_{2}, T_{3}$ prezentowanych $\mathrm{w}$ rozdziale 2.2 .2 (wartości statystyk nie dają podstaw do odrzucenia hipotezy o braku istotnych zmian w nierównościach w początkowym i końcowym okresie badania).

Poniżej sprawdzono, czy hipoteza o sigma-konwergencji może być potwierdzona w mniejszych grupach województw. $Z$ wykresów 3.3.3.2a- 3.3.3.2b można odczytać, że zróżnicowanie TFP spada przede wszystkim w grupie województw najbiedniejszych, w następnej kolejności wśród tych o średnim poziomie zamożności (samo usunięcie województwa mazowieckiego nie spowodowało 
zmian w zróżnicowaniu). W podsumowaniu zawartym w podrozdziale 3.5 poświęcono więcej miejsca na komentarz do tych faktów.

Wykres 3.3.3.2a. Wspólczynnik zmienności dla $T F P_{a}$ w grupach województw

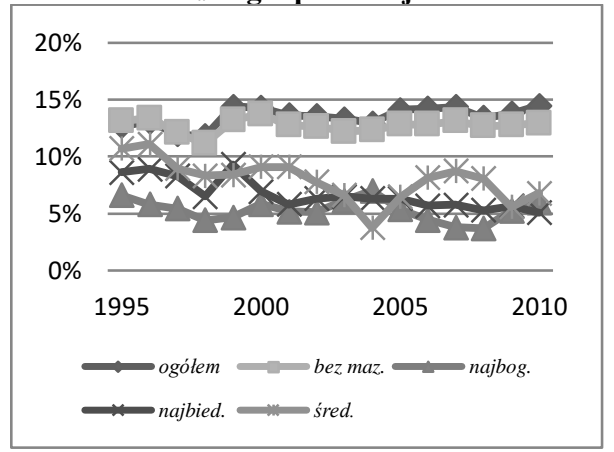

Źródło: opracowanie własne
Wykres 3.3.3.2b. Wspólczynnik zmienności dla $T_{F P}$ w grupach województw

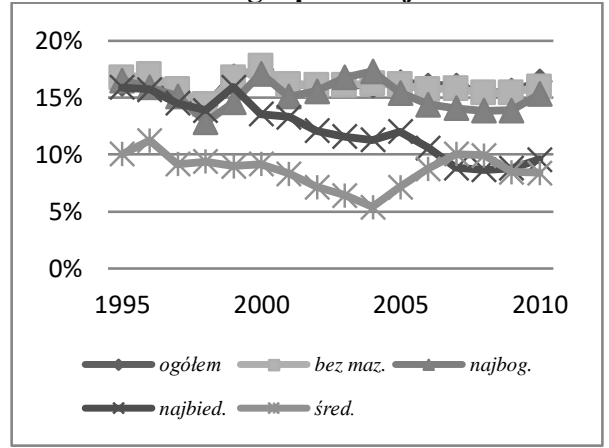

\subsubsection{Gamma-konwergencja}

Nie należy przypuszczać, że tego rodzaju konwergencja występuje wśród wszystkich 16 województw Polski, bowiem jej istnienie oznaczałoby, że regiony o początkowo niskiej wartości TFP (np. Polska Wschodnia) wykazały tak wysokie tempa wzrostu tej zmiennej, że wyprzedziły regiony o początkowo wysokich wartościach TFP (czyli takie województwa jak dolnośląskie, czy śląskie $^{43}$ ). Niemniej zweryfikowano hipotezę o gamma-konwergencji TFP, poprzez badanie trendu w kolejnych współczynnikach konkordancji rang Kendalladla wojewódzkich TFP, które zobrazowano na wykresacg 3.3.3.1a-3.3.3.1b. $\mathrm{Na}$ obu wykresach można zauważyć malejącą tendencję w kolejnych współczynnikach $R C_{t}$, lecz jest ona, dla $T F P_{b}$ nieistotna statystycznie (co zgodnie $\mathrm{z}$ modyfikacjami przedstawionymi w podrozdziale 2.3 .2 wystarcza, aby stwierdzić, że nie doszło do istotnej zmiany pozycji województw w rankingu pod względem $T F P$ ), zaś dla $T F P_{a}$ dodatkowy test w postaci statystyki (2.3.2.4) pozwala na odrzucenie hipotezy, że wartość współczynnika konkordancji rang w roku 2010 jest istotnie różna od zera (brak zmiany uporządkowań województw w rankigu $T F P_{a}$ - brak gamma-konwergencji).

\footnotetext{
${ }^{43}$ Wydaje się również, że zaledwie 16-sto letni okres badania jest również zbyt krótki, aby takie „rewolucyjne” przemiany w skali całego kraju mogły mieć miejsce.
} 
Wykres 3.3.3.1a. Współczynniki konkordancji rang Kendalla dla $\boldsymbol{T F P}_{a}$

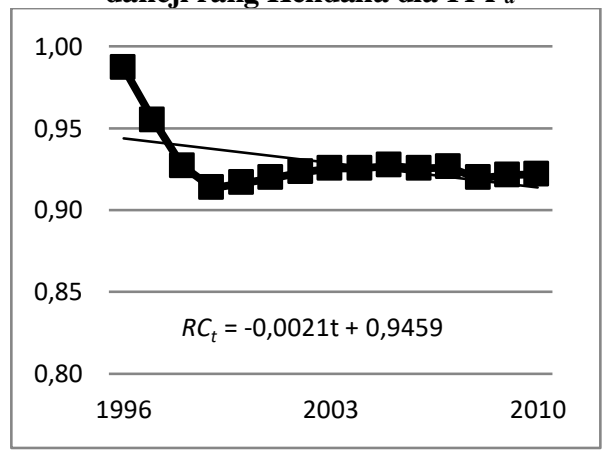

Wykres 3.3.3.1b. Współczynniki konkordancji rang Kendalla dla $T_{F P}$

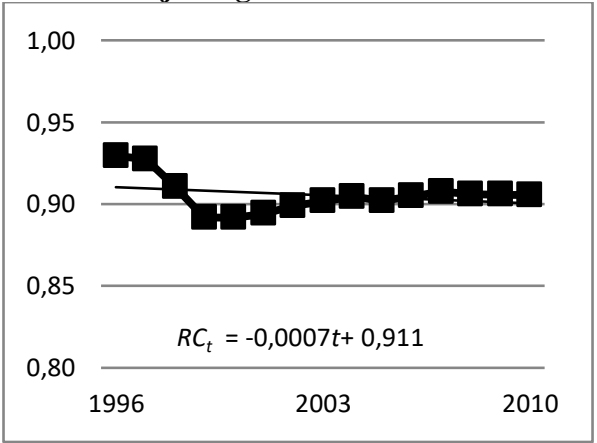

Źródło: opracowanie własne

Brak globalnej gamma-konwergencji TFP nie wyklucza istnienia jej lokalnej wersji. W istocie, po podzieleniu województw na grupy zamożności, wykresy powyższe wyglądają całkowicie odmiennie - por. wykres 3.3.3.2a-3.3.3.2b. Pokazują one bardzo szybkie zmniejszanie się współczynników konkordancji rang, tak, że ostatnie wartości są zerowe - co wskazuje na to, że we wszystkich grupach doszło do zmiany uporządkowania, czyli gamma-konwergencji (co potwierdzają wszystkie statystyki testowe weryfikujące hipotezy o gammakonwergencji z podrozdziałów 2.3.1-2.3.2). Oznacza to, że zmiany TFP wewnątrz grup są bardzo duże - na tyle, że doprowadzają do zmian pozycji województw w rankingu grupy pod względem TFP (wątek ten podjęto w szerszym kontekście w podsumowaniu całego rozdziału).

Wykres 3.3.3.2a. Współczynniki konkordancji rang Kendalla dla $\boldsymbol{T F P}_{a}$

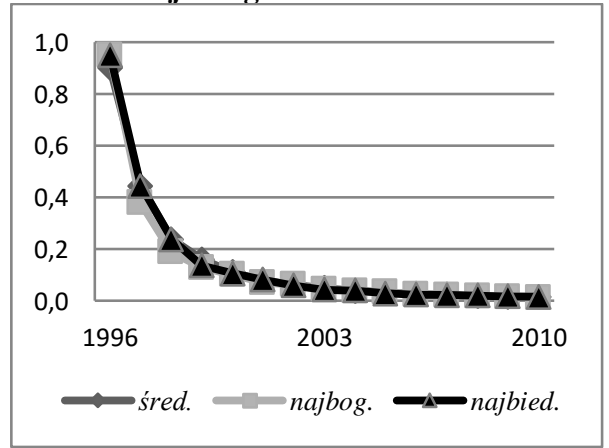

Wykres 3.3.3.2b. Współczynniki konkordancji rang Kendalla dla $\boldsymbol{T F P}_{b}$

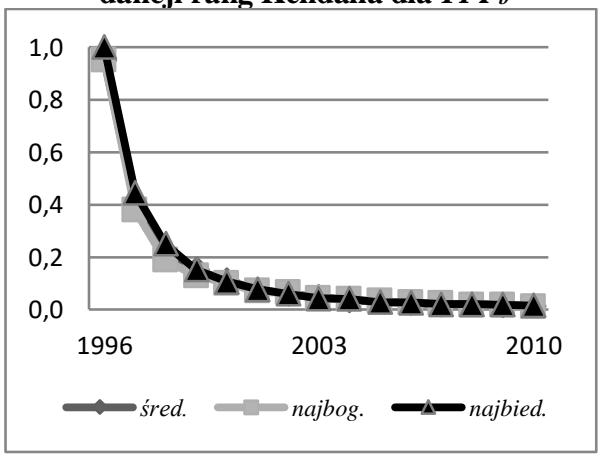

Źródło: opracowanie własne 


\subsubsection{Wyznaczenie stanów równowagi wojewódzkiej}

Wpływ TFP na wzrost gospodarczy i konwergencję był już wielokrotnie podkreślany w tej pracy, lecz jego bezpośrednie oddziaływanie jest najlepiej widoczne w przypadku wyznaczania steady-state. W podrozdziale 1.2.1 wyprowadzono wzory (1.2.1.6-1.2.1.9) umożliwiające wyznaczenie wartości kapitału na pracującego (technicznego uzbrojenia pracy) oraz produkcji na pracującego (wydajności pracy) w stanie równowagi. Wzory te można zapisać w następującej postaci:

$$
k_{i}^{*}=\left(\frac{T F P_{i} s_{i}}{n_{i}+\delta}\right)^{\frac{1}{1-\alpha_{i}}} \quad y_{i}^{*}=\left(\frac{T F P_{i} s_{i}}{n_{i}+\delta}\right)^{\frac{\alpha_{i}}{1-\alpha_{i}}}
$$

gdzie:

$k_{i}$ - kapitał (fizyczny) na pracującego (techniczne uzbrojenie pracy) w regionie $i$ mierzony wartością brutto środków trwałych w cenach stałych,

$T F P_{i}$ - całkowita łączna produktywność czynników produkcji w regionie $i$,

$n_{i}$ - tempo wzrostu liczby pracujących w regionie $i$,

$\delta$ - stopa deprecjacji kapitału,

$\alpha_{i}$ - elastyczność produkcji względem kapitału (fizycznego) w regionie $i$,

$i=1, \ldots, 16, t=1995, \ldots, 2010$.

Stany równowagi dane wzorem (3.3.4.1) wyznaczono w dwóch wariantach. W obu przyjęto zróżnicowaną w województwach stopę oszczędności $\left(s_{i}\right)$ i tempo wzrostu liczby pracujących $n_{i}$ (takie jak w tabeli 3.2.1.1) oraz identyczną dla wszystkich województw stopę deprecjacji kapitału $\delta=0,06$ (na podstawie wyliczeń z rozdziału 3.1.3) oraz stałą elastyczność produkcji względem kapitału $\alpha=0,57$ (na podstawie wyliczeń z rozdziału 3.1.2). To, co różniło poniższe warianty, to założenie o wartości elastyczności produkcji $\alpha$ we wzorze 3.3.4.1, która podobnie do poprzednich badań, była albo na takim samym poziomie we wszystkich województwach $\alpha=0,57$, albo zróżnicowana wojewódzko wg ostatniej kolumny tabeli 3.1.2.1.

W tabelach 3.3.4.1-3.3.4.2 znajdują się wartości technicznego uzbrojenia pracy $\left(k^{*}\right)$ i wydajności pracy $\left(y^{*}\right)$ w stanach ustalonych wraz z obliczonymi dla nich współczynnikami szybkości konwergencji $(\beta)$ i okresami połowicznej zbieżności (tzw. half-life - por. wzór 2.1.1.3). 
Tabela 3.3.4.1. Wartość kapitału na pracującego w stacjonarnym stanie równowagi

\begin{tabular}{|c|c|c|c|c|c|c|}
\hline \multirow[b]{2}{*}{ Województwo } & \multicolumn{3}{|c|}{ Wariant I $(\alpha=0,57)$} & \multicolumn{3}{|c|}{ Wariant II (dla $\alpha_{i}$ wg tab. 3.1.2.1) } \\
\hline & $\begin{array}{c}\boldsymbol{k}^{*} \\
\text { w tys. zł na } \\
1 \text { prac. }\end{array}$ & $\boldsymbol{\beta}$ & Half-life & $\begin{array}{c}\boldsymbol{k}^{*} \\
\text { w tys. zł na } \\
1 \text { prac. }\end{array}$ & $\beta$ & Half-life \\
\hline dolnośląskie & 411 & $2,7 \%$ & 25 & 471 & $2,7 \%$ & 25 \\
\hline kujawsko-pom. & 358 & $2,4 \%$ & 28 & 363 & $2,4 \%$ & 28 \\
\hline lubelskie & 285 & $2,6 \%$ & 26 & 148 & $2,6 \%$ & 26 \\
\hline lubuskie & 272 & $3,2 \%$ & 22 & 237 & $3,2 \%$ & 22 \\
\hline łódzkie & 287 & $2,8 \%$ & 25 & 227 & $2,8 \%$ & 25 \\
\hline małopolskie & 474 & $2,5 \%$ & 28 & 403 & $2,5 \%$ & 28 \\
\hline mazowieckie & 483 & $3,0 \%$ & 23 & 642 & $3,0 \%$ & 23 \\
\hline opolskie & 624 & $2,1 \%$ & 34 & 406 & $2,1 \%$ & 34 \\
\hline podkarpackie & 381 & $2,7 \%$ & 26 & 244 & $2,7 \%$ & 26 \\
\hline podlaskie & 496 & $2,4 \%$ & 29 & 297 & $2,4 \%$ & 29 \\
\hline pomorskie & 379 & $2,8 \%$ & 25 & 428 & $2,8 \%$ & 25 \\
\hline śląskie & 267 & $2,8 \%$ & 25 & 343 & $2,8 \%$ & 25 \\
\hline świętokrzyskie & 380 & $2,6 \%$ & 26 & 230 & $2,6 \%$ & 26 \\
\hline warm.-maz. & 235 & $3,1 \%$ & 22 & 177 & $3,1 \%$ & 22 \\
\hline wielkopolskie & 440 & $2,6 \%$ & 27 & 486 & $2,6 \%$ & 27 \\
\hline zachodniopom. & 478 & $2,3 \%$ & 30 & 461 & $2,3 \%$ & 30 \\
\hline
\end{tabular}

Źródło: obliczenia własne

Tabela 3.3.4.2. Wartość wydajności pracy (WDB na pracującego) w stanie równowagi

\begin{tabular}{|c|c|c|c|c|c|c|}
\hline \multirow[b]{2}{*}{ Województwo } & \multicolumn{3}{|c|}{ Wariant I $(\alpha=0,57)$} & \multicolumn{3}{|c|}{ Wariant II (dla $\alpha_{i}$ wg tab. 3.1.2.1) } \\
\hline & $\begin{array}{c}\boldsymbol{y}^{*} \\
\text { w tys. zł na } \\
1 \text { prac. }\end{array}$ & $\boldsymbol{\beta}$ & Half-life & $\begin{array}{c}y^{*} \\
\text { w tys. zł na } \\
1 \text { prac. }\end{array}$ & $\beta$ & Half-life \\
\hline dolnośląskie & 108 & $2,7 \%$ & 25 & 124 & $2,7 \%$ & 25 \\
\hline kujawsko-pom. & 100 & $2,4 \%$ & 28 & 101 & $2,4 \%$ & 28 \\
\hline lubelskie & 88 & $2,6 \%$ & 26 & 46 & $2,6 \%$ & 26 \\
\hline lubuskie & 85 & $3,2 \%$ & 22 & 75 & $3,2 \%$ & 22 \\
\hline łódzkie & 88 & $2,8 \%$ & 25 & 70 & $2,8 \%$ & 25 \\
\hline małopolskie & 117 & $2,5 \%$ & 28 & 100 & $2,5 \%$ & 28 \\
\hline mazowieckie & 119 & $3,0 \%$ & 23 & 157 & $3,0 \%$ & 23 \\
\hline opolskie & 137 & $2,1 \%$ & 34 & 89 & $2,1 \%$ & 34 \\
\hline podkarpackie & 104 & $2,7 \%$ & 26 & 66 & $2,7 \%$ & 26 \\
\hline podlaskie & 120 & $2,4 \%$ & 29 & 72 & $2,4 \%$ & 29 \\
\hline pomorskie & 103 & $2,8 \%$ & 25 & 117 & $2,8 \%$ & 25 \\
\hline śląskie & 85 & $2,8 \%$ & 25 & 109 & $2,8 \%$ & 25 \\
\hline świętokrzyskie & 103 & $2,6 \%$ & 26 & 63 & $2,6 \%$ & 26 \\
\hline warm.-maz. & 79 & $3,1 \%$ & 22 & 59 & $3,1 \%$ & 22 \\
\hline wielkopolskie & 112 & $2,6 \%$ & 27 & 124 & $2,6 \%$ & 27 \\
\hline zachodniopom. & 118 & $2,3 \%$ & 30 & 114 & $2,3 \%$ & 30 \\
\hline
\end{tabular}

Źródło: obliczenia własne 
Z powyższych tabel wynika, że osiągnięcie stanu równowagi zajmie województwom czas mierzony raczej w pokoleniach niż w latach. Na podstawie w pełni skonkretyzowanego modelu można szacować, że zmniejszenie o połowę różnicy między obecnym stanem gospodarek a stanem równowagi zajmie średnio 26 lat ${ }^{44}$. Jednakże czas ten nie jest taki sam dla poszczególnych województw. Najszybciej stan równowagi (a więc stan w którym kapitał nie będzie już się powiększał) osiągną województwa: lubuskie, warmińsko-mazurskie, mazowieckie. Jak widać wśród województw, które są stosunkowo najbliżej swojego stea$d y$-state są zarówno te, w których bieżące wyposażenie w kapitał jest wysokie (mazowieckie, mające 1 pozycję pod względem technicznego uzbrojenia pracy w 2010 r.), jak i niskie (lubuskie, warmińsko-mazurskie mające odpowiednio 9. i 12. pozycję). Szybsze osiągnięcie stanu równowagi przez te województwa nie wynika $\mathrm{z}$ wysokich stóp wzrostu tej zmiennej, lecz $\mathrm{z}$ faktu, że poziom równowagi jest stosunkowo bliski obecnemu poziomowi kapitału na pracującego (choć ciągle mówimy o różnicach kilkukrotnych - por tabela 3.3.4.3). Województwa, w których czas potrzebny do osiągnięcia stanu równowagi jest największy to przede wszystkim opolskie (dla którego okres połowicznej zbieżności wynosi 34 lata), a także zachodniopomorskie, podlaskie, kujawskopomorskie i małopolskie ${ }^{45}$. Również wśród tej grupy znajdują się zarówno województwa o wysokim, jak i niskim wyposażeniu w techniczne uzbrojenie pracy.

Z tabel 3.3.4.1 - 3.3.4.2 wyliczyć również można, że ranking województw po osiągnięciu przez nie stanów równowagi (w porównaniu do dotychczasowego) - będzie inny, co pokazuje tabela 3.3.4.3. Zmiany wśród dzisiejszych liderów wydajności pracy mogą być znaczące, co pokazują ostatnie 3 kolumny tabeli 3.3.4.3. $\mathrm{Z}$ tabel tych wynika również, że przy założeniu identycznej elastyczności produkcji, nierówności w wydajności pracy w stanie równowagi będą niższe niż obecnie. Zupełnie inaczej jest przy założeniu zróżnicowanych wojewódzko elastyczności produkcji - co ponownie pokazuje rolę parametryzacji modelu we wnioskowaniu o konwergencji.

\footnotetext{
${ }^{44}$ Nieco wyższy (33 lata) okres połowicznej zbieżności (half-life) uzyskano w pracy Malagi i Klibera [2007, s. 78], których model estymowany był jednakże dla znacząco krótszej próby 19982003.

${ }^{45}$ Należy pokreślić, że na czas połowicznej zbieżności ma wpływ parametryzacja modelu. Wspomniano tutaj o roli elastyczności produkcji względem kapitału, tempa wzrostu liczby pracujących, tempa wzrostu łącznej produktywności czynników produkcji, ale jest jeszcze jeden parametru - stopa deprecjacji kapitału, którego zróżnicowanie w poszczególnych województwach znacząco wpływa na szybkość zbieżności i, w konsekwencji, na czas potrzebny województwom do osiągnięcia ich steady-state.
} 
Tabela 3.3.4.3. Ranking województw pod względem faktycznego poziomu wydajności pracy ( $y_{2010} \mathrm{w}$ tys. zl na pracującego) oraz pod względem poziomu tej zmiennej w stanie równowagi wyznaczonym w dwóch wariantach $(y *(I)$ i $y *(I I))$

\begin{tabular}{|l|c|c|c|c|c|c|}
\hline Województwo & $\boldsymbol{y}_{\mathbf{2 0 1 0}}$ & $\boldsymbol{y}^{*}(\mathbf{I})$ & $\boldsymbol{y}^{*}(\mathbf{I I})$ & $\begin{array}{c}\text { Pozycja } \\
\boldsymbol{y}_{\mathbf{2 0 1 0}}\end{array}$ & $\begin{array}{c}\text { Pozycja } \\
\boldsymbol{y}^{*(\mathbf{I})}\end{array}$ & $\begin{array}{c}\text { Pozycja } \\
\boldsymbol{y}^{*}(\mathbf{I I})\end{array}$ \\
\hline dolnośląskie & 41 & 108 & 124 & 3 & 7 & 3 \\
\hline kujawsko-pomorskie & 36 & 100 & 101 & 7 & 11 & 7 \\
\hline lubelskie & 25 & 88 & 46 & 15 & 13 & 16 \\
\hline lubuskie & 37 & 85 & 75 & 6 & 14 & 10 \\
\hline łódzkie & 28 & 88 & 70 & 12 & 12 & 12 \\
\hline małopolskie & 29 & 117 & 100 & 11 & 5 & 8 \\
\hline mazowieckie & 42 & 119 & 157 & 2 & 3 & 1 \\
\hline opolskie & 34 & 137 & 89 & 10 & 1 & 9 \\
\hline podkarpackie & 26 & 104 & 66 & 13 & 8 & 13 \\
\hline podlaskie & 25 & 120 & 72 & 14 & 2 & 11 \\
\hline pomorskie & 40 & 103 & 117 & 4 & 10 & 4 \\
\hline śląskie & 44 & 85 & 109 & 1 & 15 & 6 \\
\hline świętokrzyskie & 24 & 103 & 63 & 16 & 9 & 14 \\
\hline warmińsko.- & 34 & 79 & 59 & 9 & 16 & 15 \\
\hline wielkopolskie & 35 & 112 & 124 & 8 & 6 & 2 \\
\hline zachodniopomorskie & 39 & 118 & 114 & 5 & 4 & 5 \\
\hline \multicolumn{1}{|l}{$\mathbf{V}$} & $\mathbf{2 0 \%}$ & $\mathbf{1 6 \%}$ & $\mathbf{3 3 \%}$ & & & \\
\hline
\end{tabular}

Na koniec wykonano jeszcze jedno doświadczenie polegające na zróżnicowaniu nie tylko w przestrzeni, ale również w czasie, łącznej produktywności czynników produkcji - TFP $i t$, co można nazwać szacowaniem „dynamicznego stanu równowagi” (por. wzór 1.2.1.7), który pokazuje nie tyle konkretną wartość stanu równowagi (do którego dążą zmienne), co ścieżkę stanu równowagi - por. wykres 3.3.4.1. Na wykresie tym wyraźnie widać grupowanie się województw dążących do niższych (lubelskie, warmińsko-mazurskie, podkarpackie, lubuskie, świętokrzyskie, podlaskie, łódzkie) i wyższych (opolskie, kujawskopomorskie, śląskie, zachodniopomorskie, małopolskie, pomorskie, wielkopolskie, dolnośląskie) poziomów stanu równowagi. Województwo mazowieckie tworzy pod tym względem osobną grupę - dążąc do maksymalnego poziomu równowagi.

${ }^{46} \mathrm{~W}$ pracy Barro [1997, s. 303] mowa jest o nieco dłuższym, 35-cio letnim, okresie. 
Wykres 3.3.4.1. Ścieżki stanów równowagi dla wydajności pracy

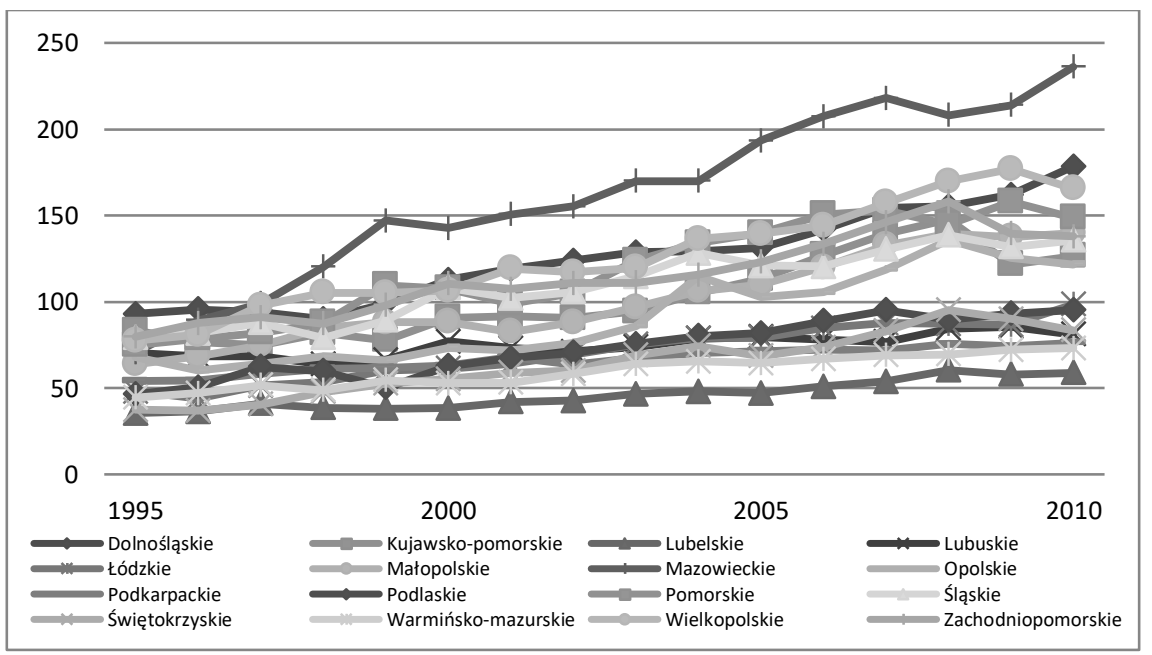

Źródło: opracowanie własne

\subsection{Konwergencja sektorowa}

\subsubsection{Ocena poziomu rozwoju województw przy wykorzystaniu sektorowej struktury pracujących}

Zgodnie z trójsektorową koncepcją struktury gospodarczej (zob. podrozdział 1.3.3) wraz ze wzrostem poziomu rozwoju i nowoczesności gospodarek zwiększa się udział zatrudnienia $w$ usługach, kosztem przemysłu i przede wszystkim rolnictwa. Wynika $\mathrm{z}$ niej, że im wyższy udział zatrudnienia $\mathrm{w}$ usługach i niższy w rolnictwie tym wyższy poziom rozwoju badanej gospodarki (lub regionu). Struktura pracujących $w$ sektorach gospodarki jest również jednym z podstawowych wskaźników gospodarczych monitorowanym w ramach celu głównego Strategii Rozwoju Kraju (SRK), jak i Narodowych Strategicznych Ram Odniesienia (NSRO).

Poniżej zbadano zmiany w strukturze pracujących w sektorach gospodarczych poszczególnych województw. W tabeli 3.4.1.1 pokazano średnie, roczne tempo wzrostu frakcji pracujących w 4 sektorach gospodarczych w latach 1995-2010 (wyliczone na podstawie wykładniczej funkcji trendu). Z tabeli tej wynika, że stosunkowo największe zmiany nastąpiły w województwie śląskim, gdzie zanotowano bardzo wysokie tempo spadku pracujących w rolnictwie, wysokie tempo spadku udziału pracujących w przemyśle i wysokie tempo wzrostu udziatu pracujących w usługach rynkowych. 
Tabela 3.4.1.1. Średnioroczne (1995-2010) tempo wzrostu frakcji pracujących w 4 sektorach gospodarki

\begin{tabular}{|l|r|r|r|r|}
\hline Województwo Sektor & Rolnictwo & \multicolumn{1}{c|}{ Przemysi } & \multicolumn{1}{c|}{$\begin{array}{c}\text { Uslugi } \\
\text { rynkowe }\end{array}$} & $\begin{array}{c}\text { Uslugi } \\
\text { nierynkowe }\end{array}$ \\
\hline dolnośląskie & $-3,3 \%$ & $0,3 \%$ & $1,9 \%$ & $-0,1 \%$ \\
\hline kujawsko-pomorskie & $-3,0 \%$ & $-0,1 \%$ & $1,3 \%$ & $-0,3 \%$ \\
\hline lubelskie & $-2,4 \%$ & $0,7 \%$ & $2,7 \%$ & $1,4 \%$ \\
\hline lubuskie & $-0,1 \%$ & $1,3 \%$ & $1,6 \%$ & $1,8 \%$ \\
\hline lódzkie & $-3,0 \%$ & $0,1 \%$ & $3,0 \%$ & $1,3 \%$ \\
\hline małopolskie & $-4,0 \%$ & $-0,4 \%$ & $2,4 \%$ & $0,7 \%$ \\
\hline mazowieckie & $-3,9 \%$ & $0,3 \%$ & $3,4 \%$ & $1,5 \%$ \\
\hline opolskie & $-3,0 \%$ & $-1,5 \%$ & $0,8 \%$ & $-1,7 \%$ \\
\hline podkarpackie & $-2,2 \%$ & $0,0 \%$ & $2,6 \%$ & $1,3 \%$ \\
\hline podlaskie & $-3,5 \%$ & $0,7 \%$ & $1,2 \%$ & $1,3 \%$ \\
\hline pomorskie & $-2,4 \%$ & $0,8 \%$ & $0,8 \%$ & $0,7 \%$ \\
\hline śląskie & $-5,4 \%$ & $-1,3 \%$ & $3,4 \%$ & $1,3 \%$ \\
\hline świętokrzyskie & $-3,2 \%$ & $0,6 \%$ & $2,4 \%$ & $2,3 \%$ \\
\hline warmińsko-mazur. & $-2,0 \%$ & $2,2 \%$ & $2,2 \%$ & $1,1 \%$ \\
\hline wielkopolskie & $-2,2 \%$ & $-0,5 \%$ & $1,0 \%$ & $0,1 \%$ \\
\hline zachodniopomorskie & $-4,2 \%$ & $-0,4 \%$ & $-0,1 \%$ & $-0,1 \%$ \\
\hline \multicolumn{2}{|r|}{ Źródło: opracowanie własne } & & \\
\hline
\end{tabular}

W celu oceny poziomu rozwoju województw pod kątem sektorowej koncepcji struktury gospodarki użyto Wskaźnika Względnego Poziomu Rozwoju $(W W P R)$, który pozwala na zastąpienie wielu zmiennych diagnostycznych jedną syntetyczną (por. Łuniewska, Tarczyński [2006]):

$$
W W P R_{i}=\frac{\sum_{j=1}^{k} z_{i j}}{\sum_{j=1}^{k} \max _{i}\left\{z_{i j}\right\}}, z_{i j}=x_{i j}^{*}+\left|\min \left\{x_{i j}^{*}\right\}\right|, x_{i j}^{*}=\frac{x_{i j}-\bar{x}_{j}}{S_{j}}
$$

gdzie: $W W P R_{i}$ - wskaźnik względnego poziomu rozwoju, $\bar{x}_{j}, S_{j}$ - średnia arytmetyczna i odchylenie standardowe $j$-tej zmiennej diagnostycznej $x$. Im bliższa 1 jest wartość $W W P R$ tym województwo charakteryzuje się wyższym poziomem przyjętego kryterium. Wartości $W W P R$ równe 1 (0) oznaczają, że wszystkie zmienne diagnostyczne dla danego województwa przyjęły wartości maksymalne (minimalne).

W tabeli 3.4.1.2 zaprezentowano wartości $W W P R$ pokazujących poziom rozwoju gospodarek województw mierzony strukturą zatrudnienia w sektorach (zmiennymi diagnostycznymi były udział pracujących $\mathrm{w}$ rolnictwie - jako destymulanta rozwoju i udział pracujących w usługach - stymulanta rozwoju). $\mathrm{Z}$ punktu widzenia teorii trzech sektorów stosunkowo najnowocześniejszą strukturą gospodarki charakteryzowało się w 1995 r. województwo zachodniopomorskie i śląskie (miały jednocześnie niski udział zatrudnienia w rolnictwie 
i wysoki w usługach), a następnie pomorskie, lubuskie, dolnośląskie, mazowieckie, opolskie ${ }^{47}$. Najniższe lokaty pod względem miernika syntetycznego miały województwa: świętokrzyskie, lubelskie, podlaskie, podkarpackie. W ciągu 16 lat pozycja poszczególnych województw zmieniła się, choć nieznacznie (współczynnik korelacji rang jest dodatni i wnosi $+0,89$ ): o ile śląskie pozostaje liderem nowoczesności (mierzonej trójsektorową strukturą gospodarki), to np. opolskie znalazło się wśród województw o najniższym poziomie miary syntetycznej, zaś stosunkowo duży wzrost pozycji w rankingu nowoczesności gospodarki zanotowało województwo mazowieckie.

Tabela 3.4.1.2. Wartość syntetycznej miary rozwoju województw i pozycja województwa pod tym względem

\begin{tabular}{|c|c|c|c|c|}
\hline $\begin{array}{l}\text { Województwo } \\
\text { Rok/pozycja }\end{array}$ & 1995 & 2010 & $\begin{array}{l}\text { Pozycja } \\
\text { w } 1995 \text { r. }\end{array}$ & $\begin{array}{l}\text { Pozycja } \\
\text { w } 2010 \text { r. }\end{array}$ \\
\hline dolnośląskie & 0,62 & 0,50 & 5 & 5 \\
\hline kujawsko-pomorskie & 0,30 & 0,22 & 10 & 10 \\
\hline lubelskie & 0,07 & 0,07 & 15 & 14 \\
\hline lubuskie & 0,63 & 0,41 & 4 & 6 \\
\hline łódzkie & 0,25 & 0,25 & 11 & 9 \\
\hline małopolskie & 0,22 & 0,25 & 12 & 8 \\
\hline mazowieckie & 0,49 & 0,56 & 6 & 2 \\
\hline opolskie & 0,40 & 0,18 & 7 & 11 \\
\hline podkarpackie & 0,12 & 0,05 & 13 & 15 \\
\hline podlaskie & 0,08 & 0,13 & 14 & 12 \\
\hline pomorskie & 0,64 & 0,52 & 3 & 3 \\
\hline Śląskie & 0,70 & 0,81 & 2 & 1 \\
\hline świętokrzyskie & 0,01 & 0,02 & 16 & 16 \\
\hline warmińsko-mazurskie & 0,38 & 0,29 & 8 & 7 \\
\hline wielkopolskie & 0,37 & 0,12 & 9 & 13 \\
\hline zachodniopomorskie & 0,73 & 0,51 & 1 & 4 \\
\hline
\end{tabular}

Źródło: opracowanie własne

Uporządkowanie województw pod względem sektorowej struktury gospodarek (z tabeli 3.4.1.2) jest dodatnio skorelowane $\mathrm{z}$ ich uporządkowaniem pod względem zamożności (mierzonej PKB per capita) - współczynnik korelacji rang Spearmana wynosi 0,83 dla roku 1995 i 0,73 w roku 2010, co pokazuje duże przełożenie struktury gospodarki województwa na jego poziom zamożności mierzony PKB per capita.

${ }^{47} \mathrm{~W}$ przypadku województwa opolskiego stosunkowo wysoki udział usług wynikał jednakże głównie z dominacji mało wydajnych usług nierynkowych. 


\subsubsection{Konwergencja struktury pracujących w 4 sektorach gospodarki}

Największe zmiany na przestrzeni lat 1995-2010 nastąpiły w Polsce $\mathrm{w}$ sektorze rolniczym. Średni udział pracujących w rolnictwie w Polsce wynosił w 1995 r. 24\% zaś w 2010 już tylko 14\%. Zmiany we frakcjach pracujących $\mathrm{w}$ rolnictwie $\mathrm{w}$ poszczególnych województwach pokazuje wykres 3.4.2.1, z którego można odczytać stosunkowo duże różnice pomiędzy województwami pod względem struktury pracujących: od województwa lubelskiego w którym blisko połowa (45\%) osób pracowała w 1995 r. w rolnictwie, do województwa śląskiego, gdzie ten odsetek wynosił wówczas 7\%.

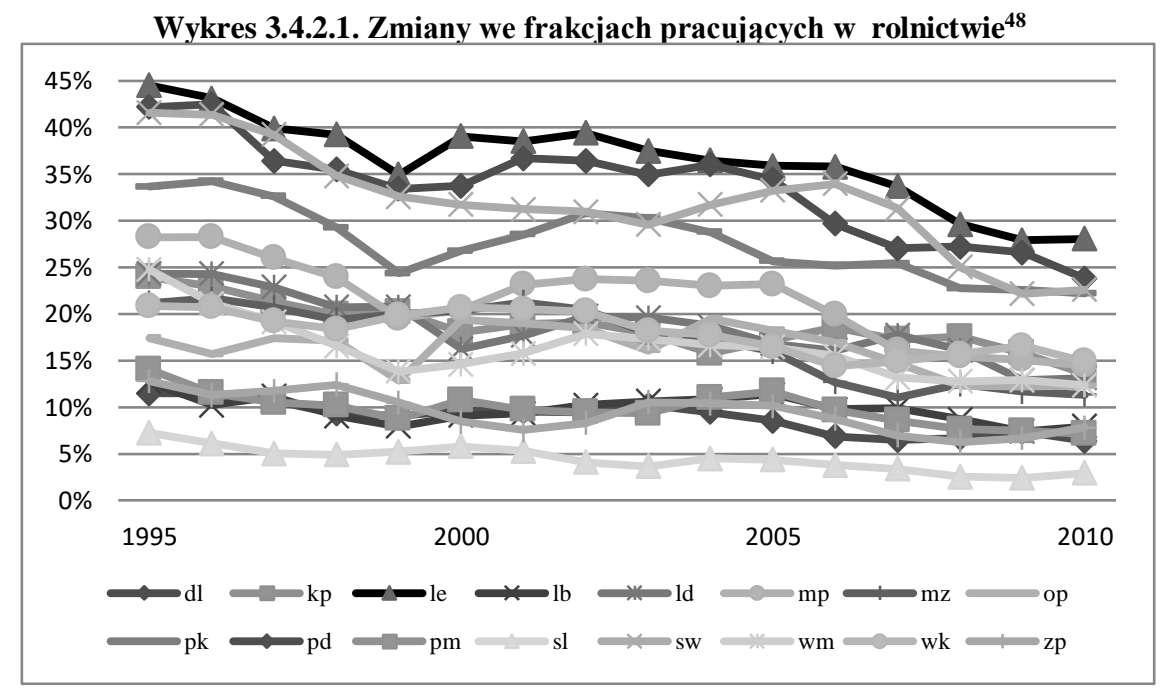

Źródło: opracowanie własne

W ostatnim roku badania (2010), pomimo znacznego spadku frakcji we wszystkich województwach, te same, co w 1995 r., województwa charakteryzował odpowiednio najwyższy i najniższy odsetek zatrudnionych w rolnictwie, a współczynnik korelacji rang Spearmana dla uporządkowania województw w 1995 i 2010 r. wynosi 0,93 - co oznacza, że pozycja województw pod względem udziału pracujących $\mathrm{w}$ rolnictwie nie zmieniła się istotnie na przestrzeni badanego okresu. Zatem zmiany frakcji pracujących, pomimo swojej intensywności, nie doprowadziły do wyrównania poziomu badanego zjawiska. $\mathrm{O}$ braku konwergencji w udziale pracujących w rolnictwie świadczą wykresy 3.4.2.1a-3.4.2.1 $\mathrm{b}^{49}$.

\footnotetext{
${ }^{48}$ Objaśnienia skrótów dla województw znajdują się w wykazie oznaczeń.

${ }^{49} \mathrm{~W}$ całym podrozdziale 3.4 .2 , w stosunku do frakcji pracujących $\mathrm{w}$ sektorze rolniczym, przemysłowym, usług rynkowych i nierynkowych policzono ten sam zestaw miar pozwalający ocenić
} 
Wykres 3.4.2.1a. Beta-konwergencja udzialów pracujących w rolnictwie

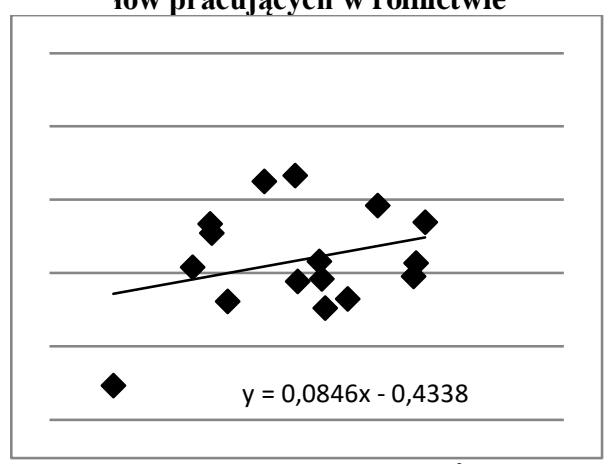

Wykres 3.4.2.1b. Sigma-konwergencja udziałów pracujących $w$ rolnictwie

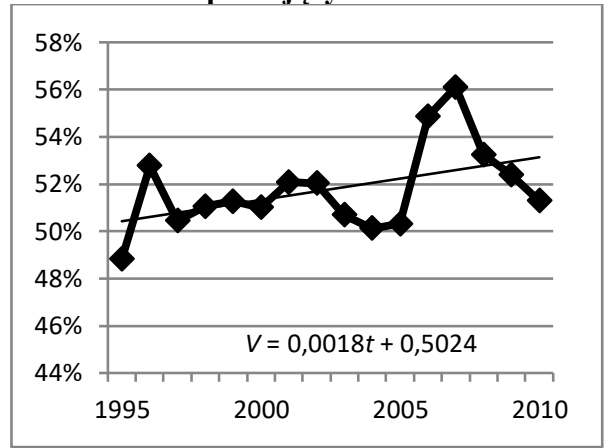

Źródło: opracowanie własne

Struktura pracujących w sektorze przemysłowym uległa na przestrzeni lat 19952010 stosunkowo najmniejszym przemianom. Zmiany te ukazano na wykresie 3.4.2.2, którego obserwacja pozwala stwierdzić, że zróżnicowanie pomiędzy województwami zmniejszyło się. $\mathrm{W}$ istocie, kierunek zmian spowodował, że pod względem udziału zatrudnienia w przemyśle polskie województwa upodobniły się do siebie (doszło do konwergencji), czego potwierdzeniem są wykresy 3.4.2.2a - 3.4.2.2b.

występowanie beta- i sigma-konwergencji, co zwizualizowano na dwóch sąsiadujących wykresach. Po lewej stronie pokazano zależność pomiędzy początkową wartością frakcji pracujących w danym sektorze (oś pozioma) a tempem zmian tego zjawiska. Jeżeli linia regresji przeprowadzona przez te punkty była ujemnie (dodatnio) nachylona, to zgodnie $\mathrm{z}$ informacjami z podrozdziału 2.1.1, wnioskowano o możliwości występowania beta-konwergencji (beta-dywergencji) absolutnej. Po prawej stronie zwizualizowano koncepcję sigma-konwergencji i pokazano zróżnicowanie w czasie (mierzone współczynnikiem zmienności $V$ ) frakcji pracujących w danym sektorze. Zgodnie ze wzorami z podrozdziału 2.2.2 malejący (rosnący) trend dla współczynnika zmienności ( $V$ ) może świadczyć o występowaniu sigma-konwergencji (sigma-dywergencji). 
Wykres 3.4.2.2. Zmiany we frakcjach pracujących w przemyśle

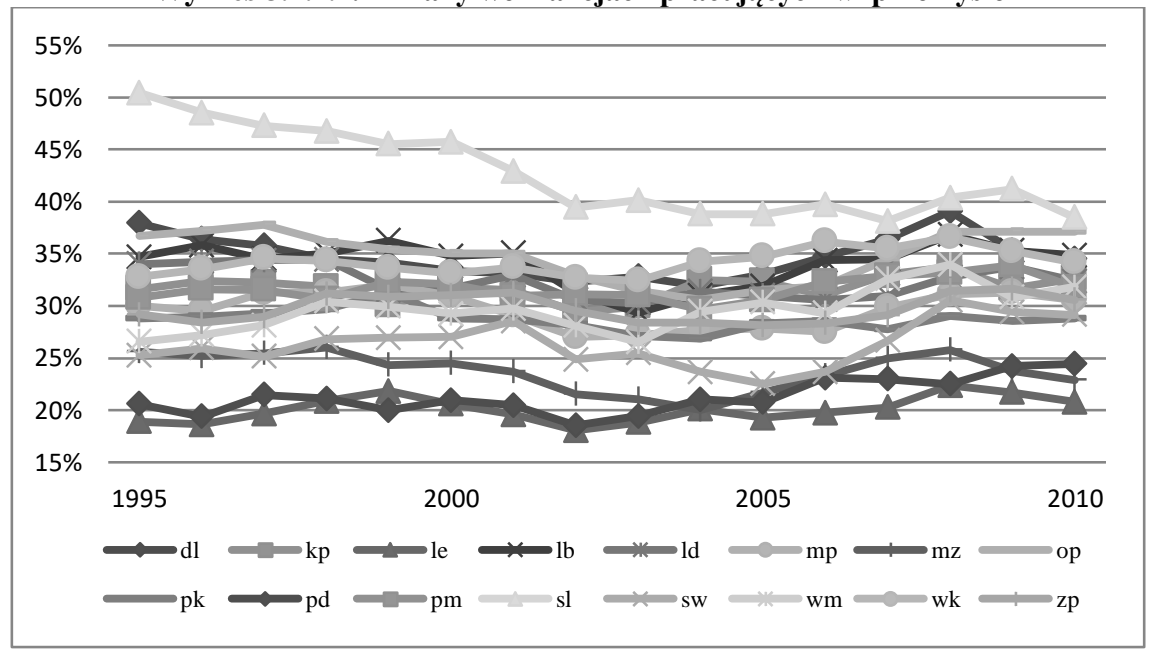

Źródło: opracowanie własne

Wykres 3.4.2.2a. Beta-konwergencja frakcji pracujących $\mathrm{w}$ przemyśle

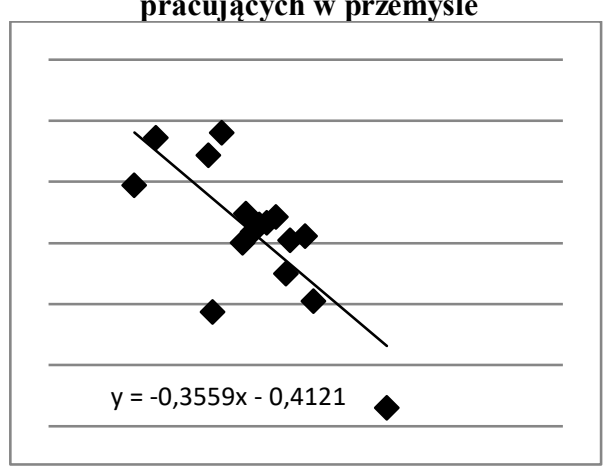

Wykres 3.4.2.2b. Sigma-konwergencja frakcji pracujących w przemyśle

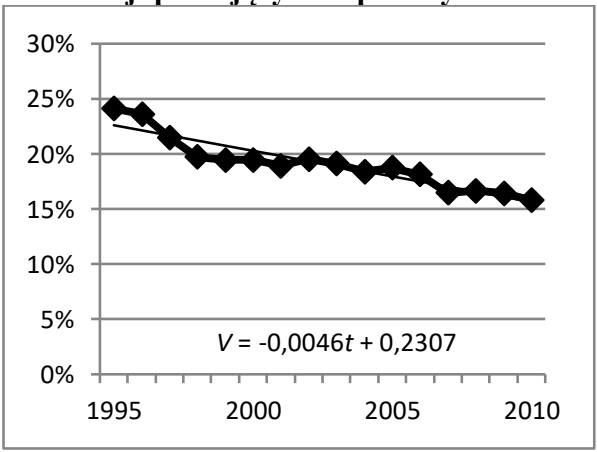

Źródło: opracowanie własne

W usługach rynkowych zaszły zmiany polegające na zwiększaniu się odsetka zatrudnionych od średnio 23\% w roku 1995 do 31\% w roku 2010. Najsilniejsze zmiany zanotowano w województwie śląskim, najsłabsze, lecz również pozytywne, w województwie lubuskim - por. wykres 3.4.2.3. Kierunek zmian w usługach rynkowych w poszczególnych województwach doprowadził do większej spójności województw w tym sektorze - o czym świadczą wykresy 3.4.2.3a-3.4.2.3b. 
Wykres 3.4.2.3. Zmiany we frakcjach pracujących w uslugach rynkowych

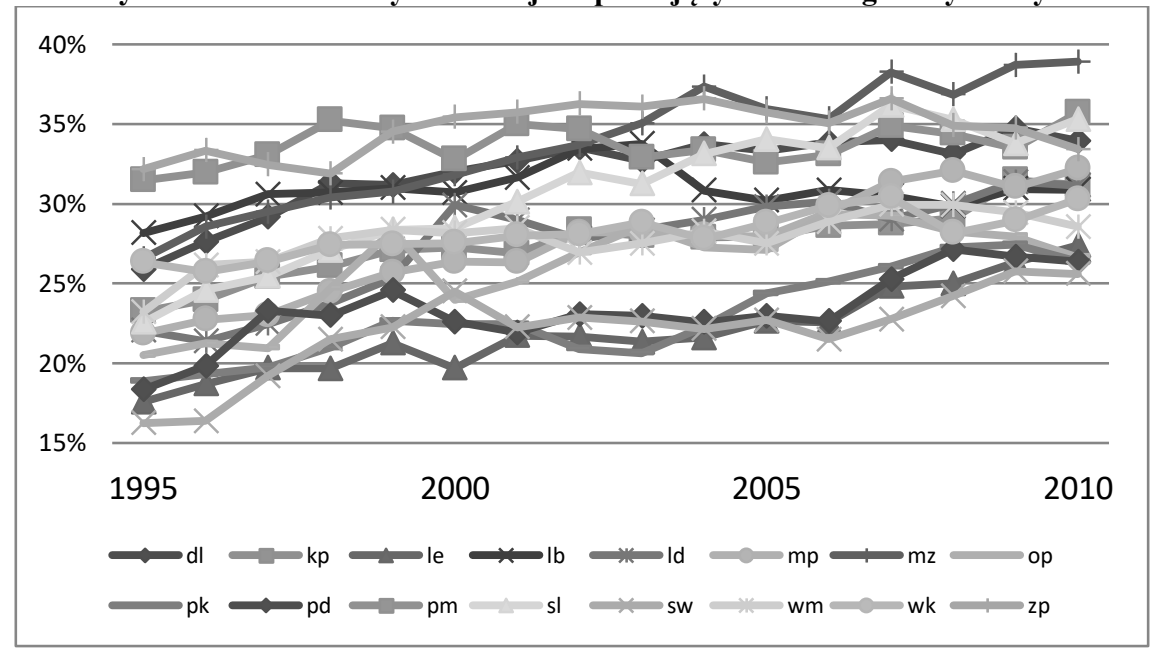

Źródło: opracowanie własne

Wykres 3.4.2.3a. Beta-konwergencja frakcji pracujących w usługach rynkowych

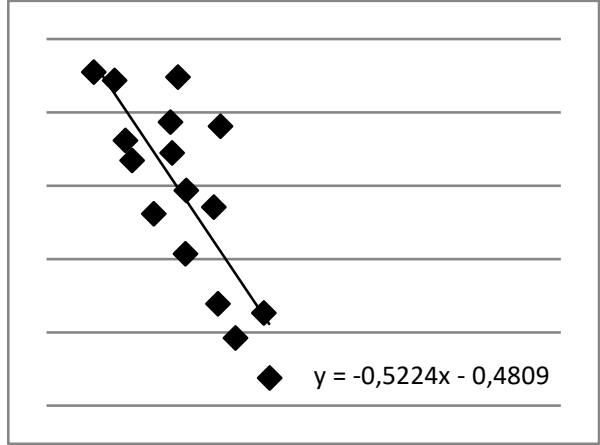

Wykres 3.4.2.3b. Sigma-konwergencja frakcji pracujących w usługach rynkowych

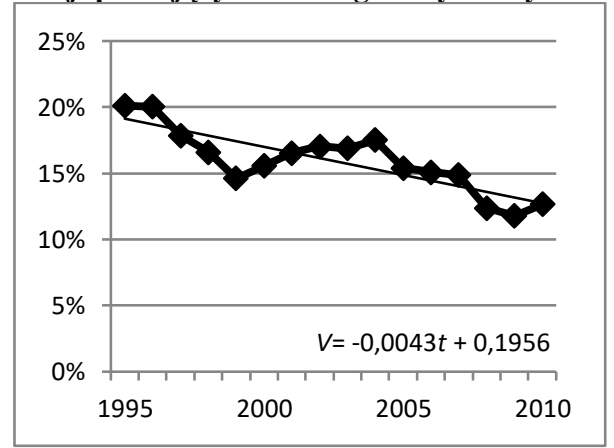

Źródło: opracowanie własne

Zmiany w usługach nierynkowych, były, podobnie jak w przemyśle, stosunkowo nieduże (por. wykres 3.4.2.4), a ich kierunek w poszczególnych województwach doprowadził do większej spójności pomiędzy województwami pod względem udziału pracujących w usługach nierynkowych, o czym świadczą wykresy 3.4.2.4a - 3.4.2.4b. 
Wykres 3.4.2.4. Zmiany we frakcjach pracujących $w$ usługach nierynkowych

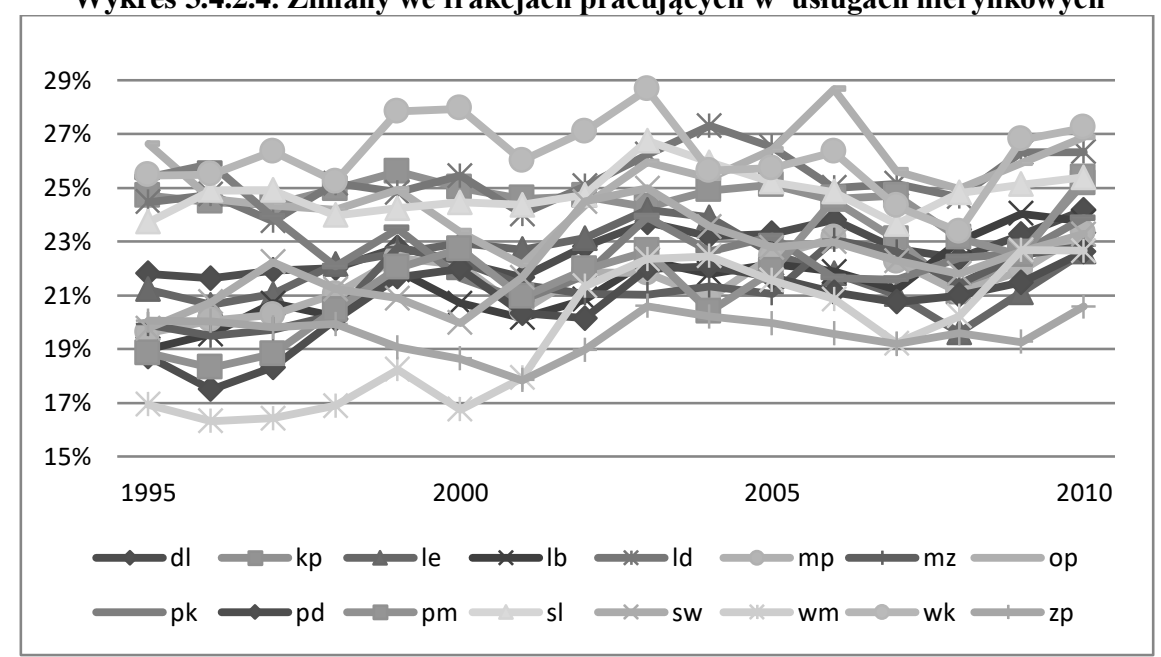

Źródło: opracowanie własne

Wykres 3.4.2.4a. Beta-konwergencja frakcji pracujących w usługach nierynkowych

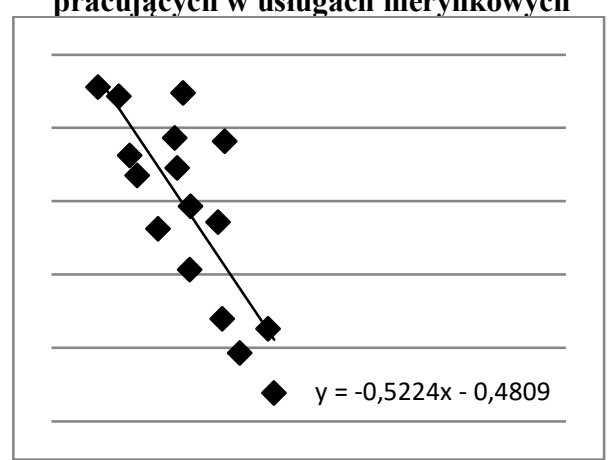

Wykres 3.4.2.4b. Sigma-konwergencja frakcji pracujących w usługach nierynkowych

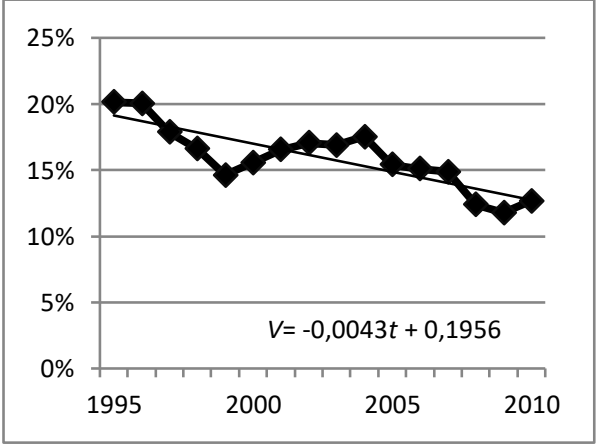

Źródło: opracowanie własne

Reasumując, należy stwierdzić, że zmiany, które zaszły w przemyśle, usługach rynkowych i nierynkowych zwiększyły zbieżność pomiędzy województwami pod względem frakcji pracujących w tych sektorach. Odmienna sytuacja cechuje rolnictwo, gdzie nastąpiły największe zmiany, lecz ich kierunki w poszczególnych województwach nie doprowadziły do konwergencji, a jedynie zwiększyły już istniejące zróżnicowanie ${ }^{50}$.

\footnotetext{
${ }^{50}$ Zgodnie $\mathrm{z}$ informacjami z rozdziału 2.2.1 w badaniach sektorowych można stosować specjalne mierniki zmienności i koncentracji oparte o ilorazy lokacyjne. Jednak zastosowanie takich mierników jak iloraz $D$ (2.2.1.1), współczynnik zmienności $V(2.2 .1 .2)$ stosowane dla ilorazów lokacyjnych, a także relatywny indeks koncentracji $R C I$ (2.2.1.11), czy lokalizacyjny indeks Giniego
} 


\subsubsection{Konwergencja wydajności pracy w 4 sektorach gospodarki}

Testy beta- oraz sigma-konwergencji zastosowano do danych dotyczących wydajności pracy w 4 sektorach gospodarki (wartości dodanej brutto na 1 pracującego). Wyniki, w postaci wykresów wizualizujących koncepcję beta i sigmakonwergencji (por. przypis nr 49) pokazano na wykresach 3.4.3.1a-3.4.3.2d.

Wykres 3.4.3.1a. Beta-konwergencja wydajności pracy $w$ rolnictwie

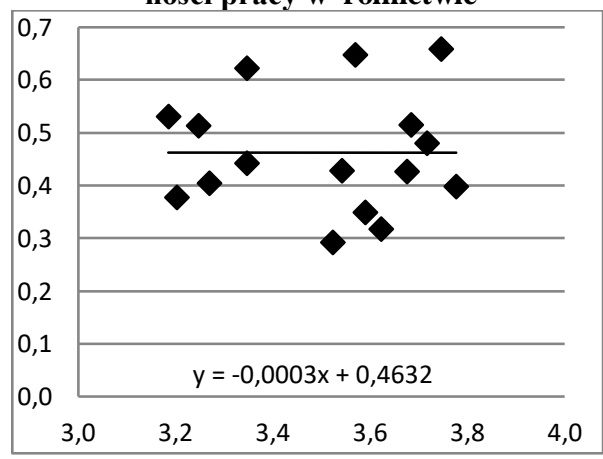

Wykres 3.4.3.1b. Beta-konwergencja wydajności pracy $w$ przemyśle

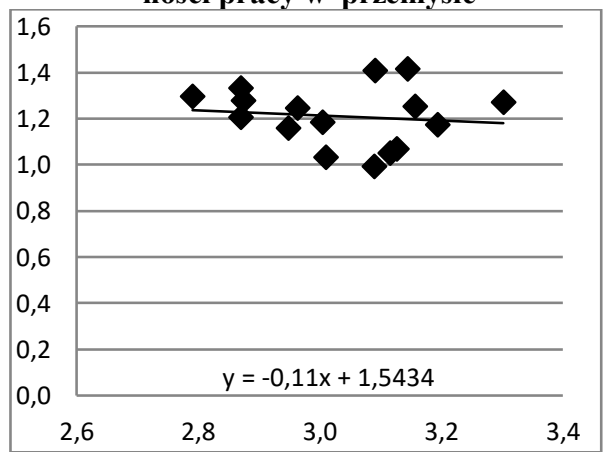

Wykres 3.4.3.1c. Beta-konwergencja wydajności pracy w usługach rynkowych

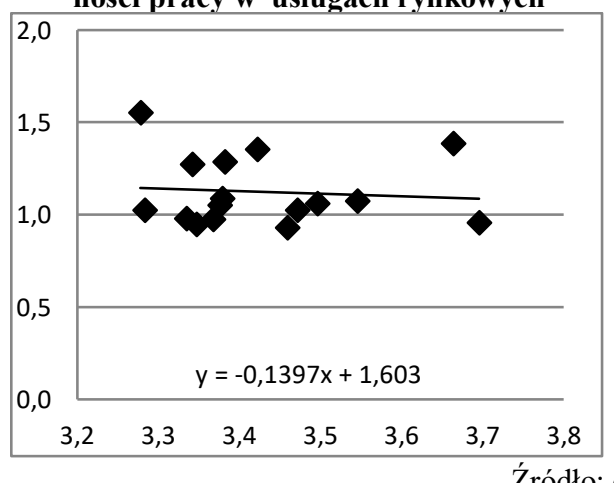

Wykres 3.4.3.1d. Beta-konwergencja wydajności pracy w usługach nierynkowych

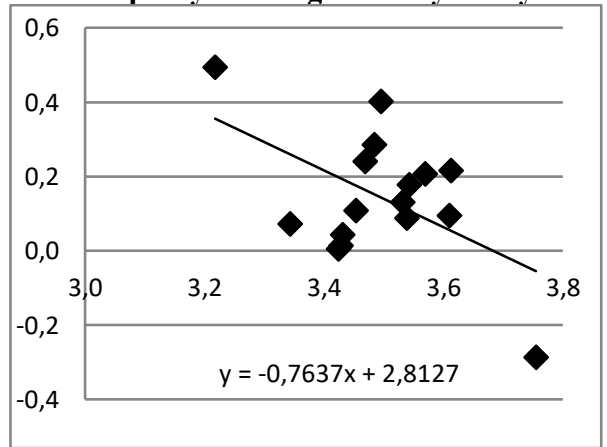

Źródło: opracowanie własne

Wszystkie powyższe równania charakteryzuje ujemny (wskazujący na proces konwergencji) współczynnik przy zmiennej objaśniającej (choć jedynie w przypadku usług nierynkowych jest on istotny statystycznie) wskazujący na tempo konwergencji równe: $0,02 \% \mathrm{w}$ rolnictwie, $0,73 \% \mathrm{w}$ przemyśle, $0,94 \%$ w usługach rynkowych i aż $8,42 \% \mathrm{w}$ usługach nierynkowych. Ostatecznie jed-

LQI (2.2.1.13) prowadzi do takich samych wniosków: spadku wojewódzkiego zróżnicowania (koncentracji) pracujących we wszystkich, poza rolniczym, sektorach. 
nak, biorąc pod uwagę testy istotności, jedynie w usługach nierynkowych można wykazać beta-konwergencję wydajności pracy ${ }^{51}$.

Potwierdzenie ujemnej zależności pomiędzy tempem wzrostu wydajności pracy a jej początkową wartością uprawnia do poszukiwań innych rodzajów konwergencji, w szczególności do weryfikacji hipotezy sigma-konwergencji. W tym celu przedstawiono wykresy zróżnicowania WDB na 1 pracującego w 4 sektorach gospodarki.

Wykres 3.4.3.2a. Sigma-konwergencja wydajności pracy $w$ rolnictwie

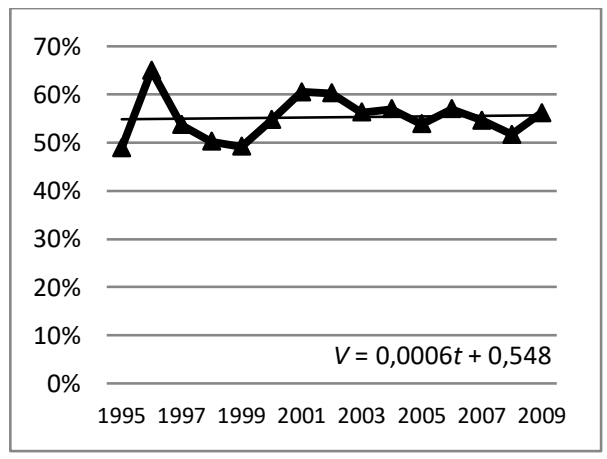

Wykres 3.4.3.2c. Sigma-konwergencja wydajności pracy $w$ usługach rynkowych

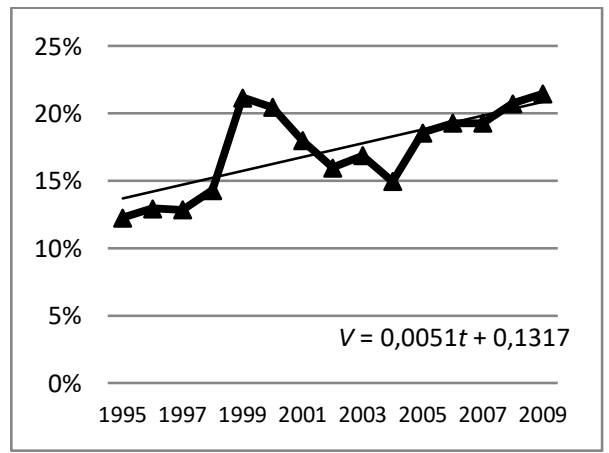

Wykres 3.4.3.2b. Sigma-konwergencja wydajności pracy w przemyśle

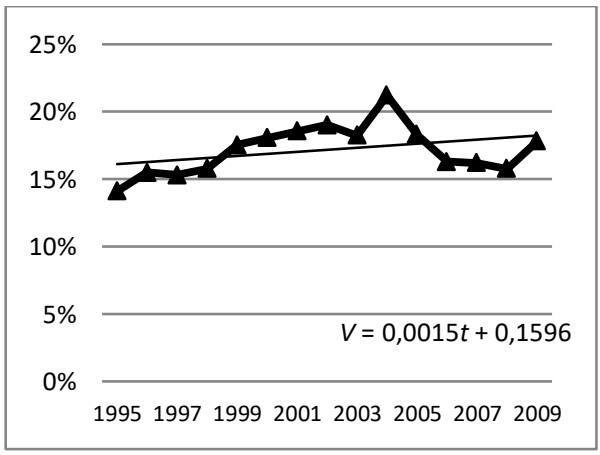

Wykres 3.4.3.2d. Sigma-konwergencja wydajności pracy w usługach rynkowych

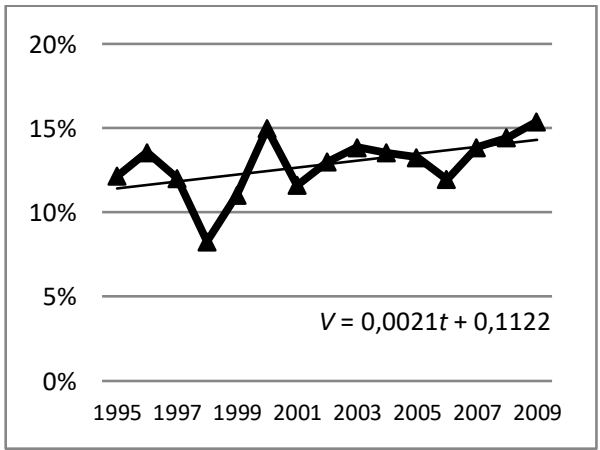

Źródło: opracowanie własne

W przeciwieństwie do struktury liczby pracujących (por. p. 3.4.2), dla której, poza rolnictwem, można było stwierdzić coraz mniejsze zróżnicowanie województw w czasie (sigma-konwergencję), wydajność pracy nie wykazuje podobnych tendencji. Biorąc pod uwagę, że frakcje pracujących w sektorach

${ }^{51}$ Choć usunięcie skrajnych obserwacji mogłoby znacznie wpłynąć na siłę nachylenia prostej na wykresie 3.4.3.1d, dlatego wniosek o beta-konwergencji w usługach nierynkowych należy traktować z ostrożnością. 
(oprócz rolnictwa) pozwalały na stwierdzenie spadku zróżnicowania w czasie (sigma-konwergencję), taki wniosek dla wydajności pracy (czyli wskaźnika liczonego jako iloraz WDB i liczby pracujących) jest sygnałem, że rozbieżności w wojewódzkiej produkcji (WDB) „biorą górę” nad tendencjami zbieżnymi w zatrudnieniu. Rzeczywiście, w przeciwieństwie do frakcji zatrudnienia, miary zmienności i koncentracji dla udziałów sektorowej produkcji rosną - zob. rys. 3.4.3.3 (wątek ten podjęto ponownie w podsumowaniu niniejszego rozdziału).

Wykres 3.4.3.3. Współczynniki zmienności i koncentracji dla ilorazów lokacyjnych wartości dodanej brutto w 4 sektorach gospodarki (lewa oś - dla przemysłu, usług rynkowych i nierynkowych, prawa- dla rolnictwa)

Współczynnik max/min (wzór 2.2.1.1)

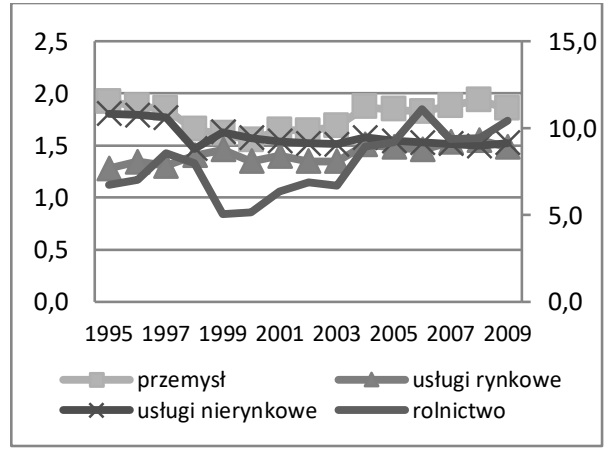

Relatywny indeks koncentracji przestrzennej (wzór 2.2.1.11)

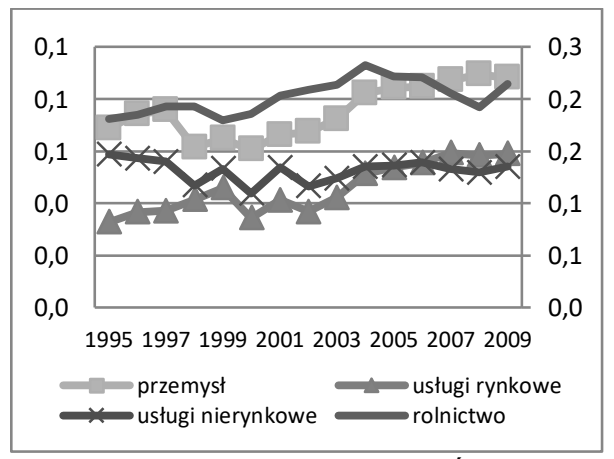

Współczynnik zmienności (wzór 2.2.1.2)

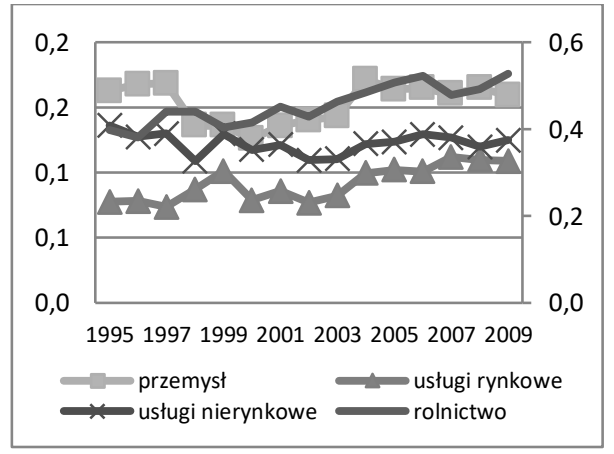

Lokalizacyjny indeks Giniego (wzór 2.2.1.12)

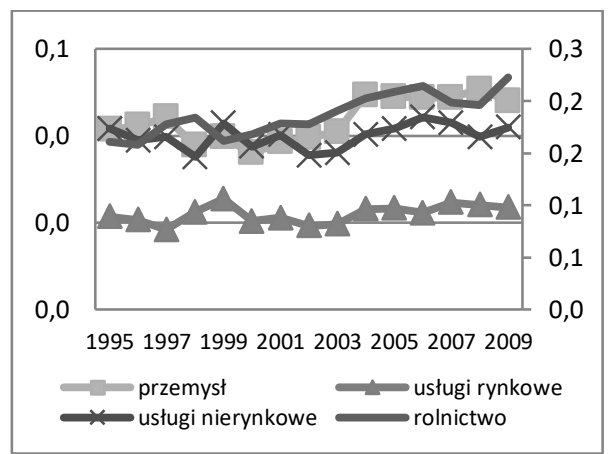

Źródło: opracowanie własne 


\subsubsection{Konwergencja TFP w 4 sektorach gospodarki}

W celu policzenia sektorowej konwergencji technologicznej (TFPkonwergencji) należało oszacować wartości TFP w poszczególnych województwach i sektorach. Wykorzystano do tego celu wzór (3.1.2.1), który, w przypadku stosowania go dla poszczególnych regionów $i$ i sektorów $j$, miał postać:

$$
T F P_{i j, t}=\frac{Y_{i j, t}}{K_{i j, t}^{\alpha_{i j}} L_{i j, t}^{\left(1-\alpha_{i j}\right)}}
$$

gdzie:

$T F P_{i j, t}$ - łączna produktywność czynników produkcji w roku $t$, regionie $i$ oraz sektorze $j$;

$K_{i j, t}$ - wartość brutto środków trwałych w cenach stałych w roku $t$, regionie $i$ oraz sektorze $j$;

$L_{i t}-$ liczba pracujących w roku $t$, regionie $i$ oraz sektorze $j$;

$Y_{i j, t}-$ wartość dodana brutto w cenach stałych w roku $t$, regionie $i$, sektorze $j$;

$\alpha_{i j}$ - elastyczność produkcji względem kapitału w regionie $i$ oraz sektorze $j$; $t=1995, \ldots, 2009, i=1, \ldots, 16, j=1, . ., 4$.

Do przeliczeń zmiennych $K_{i j, t}$ i $Y_{i j, t}$ na ceny stałe użyto następujących deflatorów:

- dla zmiennej $K_{i j, t}$ użyto deflatora nakładów brutto na środki trwałe (NBST), specyficznego dla poszczególnych sektorów gospodarczych, lecz takich samych w poszczególnych województwach;

- dla zmiennej $Y_{i j, t}$ użyto deflatorów wartości dodanej brutto $\left(W D B_{i}\right)$ - specyficznych dla poszczególnych sektorów gospodarczych lecz takich samych w poszczególnych województwach ${ }^{52}$.

Przyjęto dwie formuły elastyczności produkcji względem kapitału $\alpha$ :

1) $\alpha_{i j}$ zróżnicowane pomiędzy sektorami i wyliczane na podstawie relacji kosztów pracy $\mathrm{w}$ produkcji (por. p. 1.3.2.1); ponieważ otrzymane $\mathrm{w}$ ten sposób elastyczności były bardzo wysokie $\mathrm{w}$ rolnictwie i usługach rynkowych oraz niskie w usługach nierynkowych ${ }^{53}$, w badaniu przyjęto elastyczności będące średnią arytmetyczną z wartości wyliczanych na pod-

\footnotetext{
${ }^{52}$ Wartości deflatorów są dostępne na stronach Eurostatu. Ponieważ dostępne są tam dane w podziale na 6 grup sekcji, wyliczenia dla 4 grup sekcji: przemysłu (wraz z budownictwem), usług rynkowych i nierynkowych, dokonano na podstawie średniej ważonej deflatorów, gdzie wagami były udziały WDB danej sekcji (grupy sekcji) w WDB sektora.

${ }^{53}$ Próba oszacowania elastyczności na podstawie równania wydajności pracy dawała jeszcze bardziej nieoczekiwane wartości.
} 
stawie relacji kosztów pracy $\mathrm{w}$ produkcji i wartości $\alpha=0,5$ (por. cztery ostatnie kolumny tabeli 3.4.4.1).

2) stałe w regionach, czasie i województwach elastyczności produkcji względem kapitału na poziomie $\alpha=0,5$.

Tabela 3.4.4.1. Wartości elastyczności wynikające $\mathrm{z}$ relacji kosztów pracy w WDB oraz ostatecznie przyjęte $w$ badaniu

\begin{tabular}{|c|c|c|c|c|c|c|c|c|}
\hline \multirow[b]{2}{*}{ Województwo } & \multicolumn{4}{|c|}{ 1-(udział kosztów pracy w WDB) } & \multicolumn{4}{|c|}{$\begin{array}{l}\text { Elastyczności przyjęte w badaniach sek- } \\
\text { torowych w podejściu } 1\end{array}$} \\
\hline & Roln. & Przem. & $\begin{array}{l}\text { Ust. } \\
\text { rynk. }\end{array}$ & $\begin{array}{c}\text { Ust. } \\
\text { nieryn. }\end{array}$ & Roln. & Przem. & $\begin{array}{c}\text { Usl. } \\
\text { rynk. }\end{array}$ & $\begin{array}{c}\text { Ust. } \\
\text { nieryn. }\end{array}$ \\
\hline dolnośląskie & 0,71 & 0,50 & 0,71 & 0,32 & 0,60 & 0,50 & 0,60 & 0,41 \\
\hline kujawsko-pom. & 0,78 & 0,50 & 0,72 & 0,33 & 0,64 & 0,50 & 0,61 & 0,41 \\
\hline lubelskie & 0,83 & 0,47 & 0,71 & 0,28 & 0,67 & 0,49 & 0,60 & 0,39 \\
\hline lubuskie & 0,68 & 0,50 & 0,72 & 0,33 & 0,59 & 0,50 & 0,61 & 0,41 \\
\hline łódzkie & 0,83 & 0,50 & 0,72 & 0,30 & 0,67 & 0,50 & 0,61 & 0,40 \\
\hline małopolskie & 0,80 & 0,50 & 0,69 & 0,29 & 0,65 & 0,50 & 0,60 & 0,39 \\
\hline mazowieckie & 0,87 & 0,54 & 0,63 & 0,32 & 0,68 & 0,52 & 0,57 & 0,41 \\
\hline opolskie & 0,66 & 0,51 & 0,72 & 0,32 & 0,58 & 0,50 & 0,61 & 0,41 \\
\hline podkarpackie & 0,74 & 0,44 & 0,71 & 0,29 & 0,62 & 0,47 & 0,61 & 0,39 \\
\hline podlaskie & 0,82 & 0,50 & 0,71 & 0,31 & 0,66 & 0,50 & 0,61 & 0,41 \\
\hline pomorskie & 0,68 & 0,50 & 0,69 & 0,32 & 0,59 & 0,50 & 0,60 & 0,41 \\
\hline śląskie & 0,77 & 0,40 & 0,71 & 0,31 & 0,64 & 0,45 & 0,61 & 0,40 \\
\hline świętokrzyskie & 0,85 & 0,49 & 0,74 & 0,30 & 0,67 & 0,49 & 0,62 & 0,40 \\
\hline warmińsko- & 0,73 & 0,48 & 0,72 & 0,32 & 0,62 & 0,49 & 0,61 & 0,41 \\
\hline wielkopolskie & 0,79 & 0,52 & 0,71 & 0,33 & 0,65 & 0,51 & 0,60 & 0,41 \\
\hline zachodniopom. & 0,68 & 0,50 & 0,73 & 0,36 & 0,59 & 0,50 & 0,61 & 0,43 \\
\hline
\end{tabular}

Źródło: obliczenia własne

Poniżej znajdują się wykresy wizualizujące koncepcję beta i sigmakonwergencji sektorowych TFP (por. przypis $\mathrm{nr} 49$ ) wg pierwszego podejścia (dla zróżnicowanych w sektorach i województwach elastyczności podanych $\mathrm{w}$ czterech ostatnich kolumnach tabeli 3.4.4.1). 
Wykres 3.4.4.1a. Beta-konwergencja TFP w rolnictwie

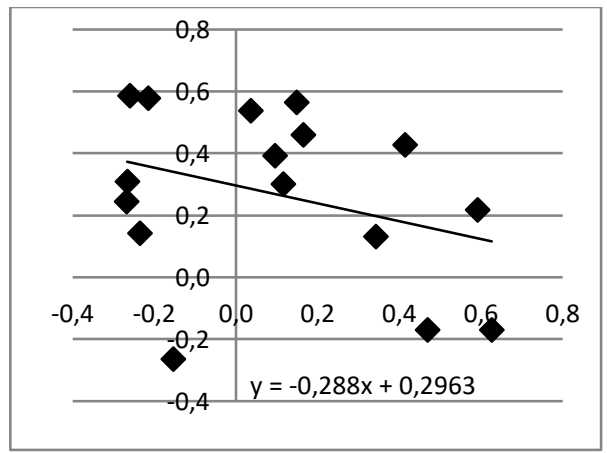

Wykres 3.4.4.1c. Beta-konwergencja TFP w usługach rynkowych

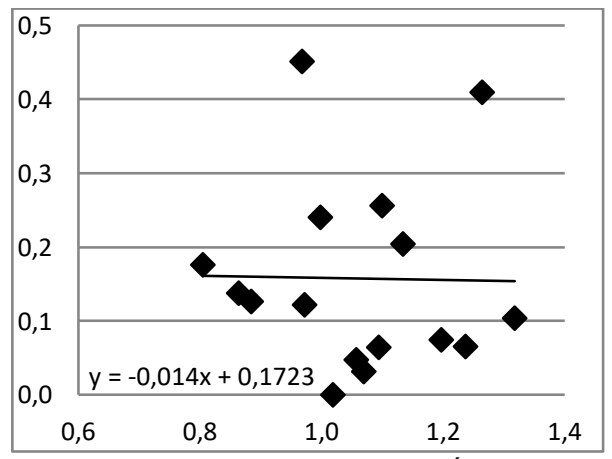

Wykres 3.4.4.1b. Beta-konwergencja TFP w przemyśle

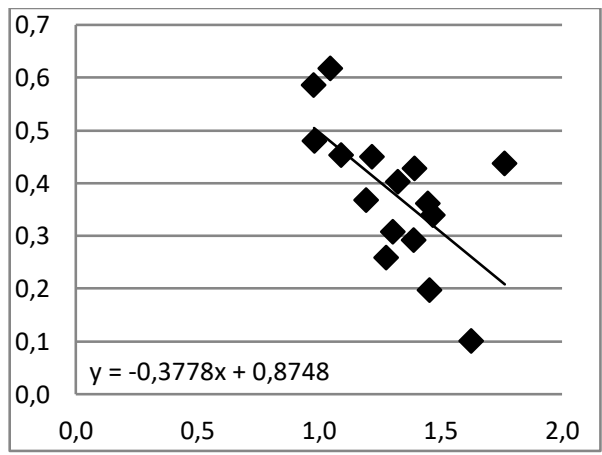

Wykres 3.4.4.1d. Beta-konwergencja TFP w usługach nierynkowych

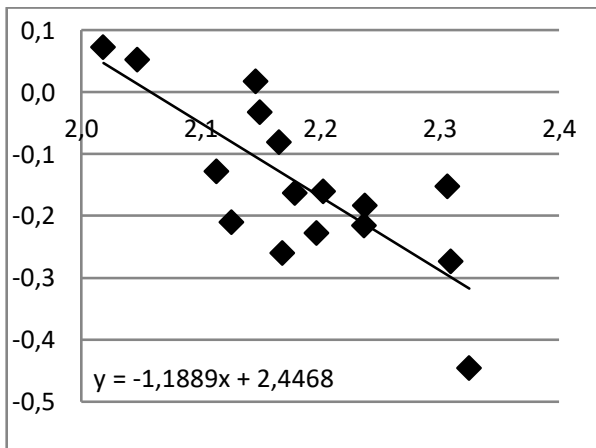

Źródło: opracowanie własne.

Z powyższych wykresów można odczytać, że we wszystkich sektorach, oprócz usług rynkowych (dla których współczynnik przy $x$ jest ujemny, lecz nieistotny statystycznie) występuje beta-konwergencja TFP. Jej szybkość jest największa $w$ usługach nierynkowych i przemyśle ${ }^{54}$. Występowanie beta-konwergencji uprawnia do pytania o drugi jej rodzaj - typ sigma - której wizualizację pokazano na wykresach 3.4.4.2a-3.4.4.2d.

\footnotetext{
${ }^{54}$ Przyjęcie drugiej formuły sektorowej elastyczności względem kapitału na stałym poziomie w sektorach, czasie i województwach rzędu $\alpha=0,5$ powoduje, że konwergencja jest silniejsza we wszystkich sektorach. W szczególności sektorze usług rynkowych, gdzie, na podstawie wykresu 3.4.4.1c nie można stwierdzić istotnej statystycznie beta-konwergencji, tymczasem przy $\alpha=0,5$ jej szybkość wynosi 3\% rocznie, zaś w rolnictwie jest to nawet 14\%. Ponownie można się przekonać (por. przypis nr 39), że przyjęcie stałej i niższej elastyczności produkcji względem kapitału zwiększa szybkość konwergencji.
} 
Wykres 3.4.4.2a. Sigma-konwergencja TFP w rolnictwie

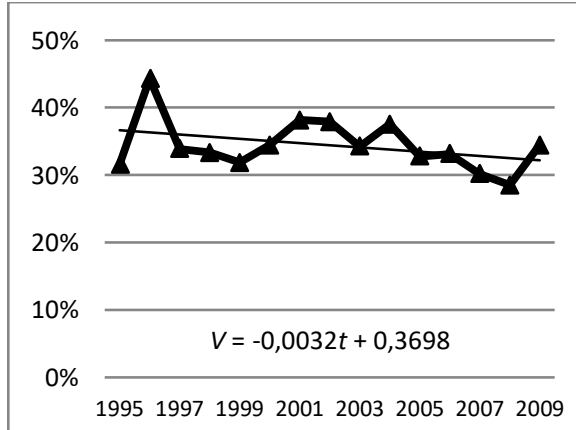

Wykres 3.4.4.2c. Sigma-konwergencja $T F P$ w uslugach rynkowych

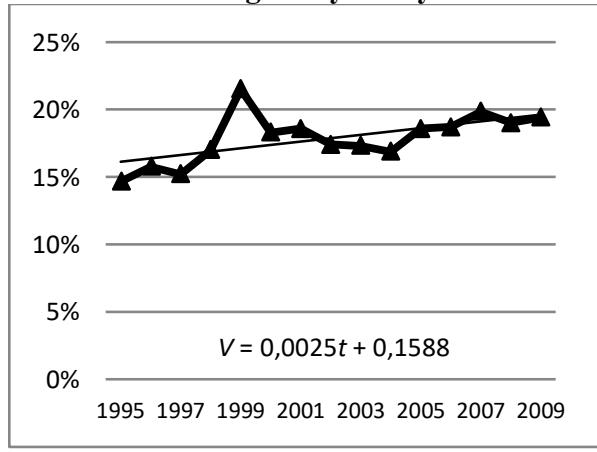

Wykres 3.4.4.2b. Sigma-konwergencja TFP w przemyśle

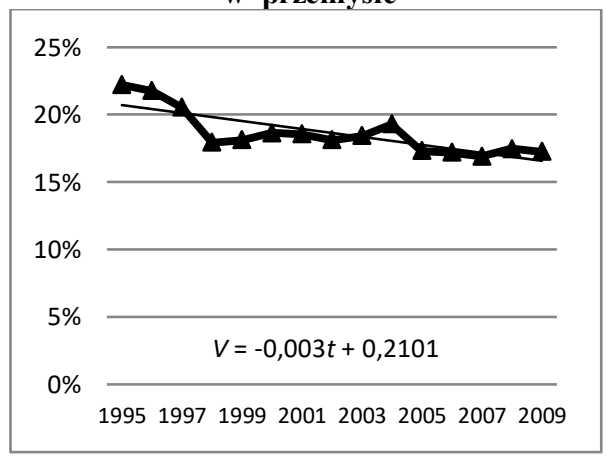

Wykres 3.4.4.2d. Sigma-konwergencja TFP w uslugach nierynkowych

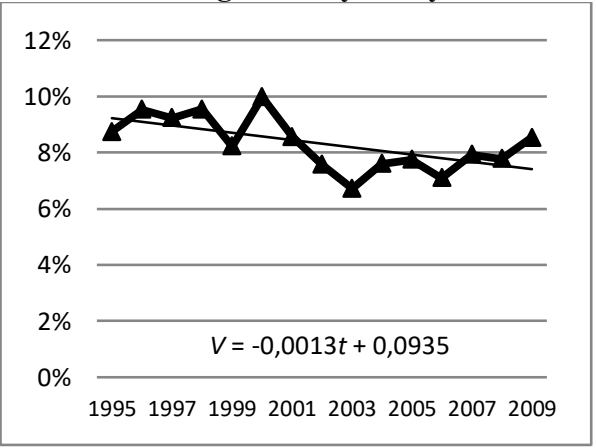

Źródło: opracowanie własne

Na powyższych wykresach można zaobserwować zmniejszanie się zróżnicowania łącznej produktywności czynników produkcji wśród województw oprócz sektora usług rynkowych, gdzie to zróżnicowanie rośnie ${ }^{55}$.

Podsumowując, można stwierdzić występowanie konwergencji TFP w trzech sektorach gospodarczych: rolnictwie, przemyśle i usługach nierynkowych. To te sektory są odpowiedzialne za coraz większą spójność łącznej produktywności czynników produkcji ogółem. Brak tej spójności w usługach rynkowych jest szczególnie negatywny, bowiem to działalności zlokalizowane w usługach rynkowych są nośnikami gospodarki opartej na wiedzy (GOW) - o czym szerzej napisano poniżej.

\footnotetext{
${ }^{55}$ Przyjęcie drugiej formuły sektorowej elastyczności produkcji względem kapitału $\alpha$ : stałej w regionach na poziomie $\alpha=0,5$, zwiększa szybkość sigma-konwergencji. Współczynnik przy zmiennej czasowej jest dwukrotnie większy dla rolnictwa, dwunastokrotnie dla przemysłu, 10-cio krotnie większy dla usług nierynkowych. Jedynie w usługach rynkowych różni się on nieznacznie od raportowanego na wykresie 3.4.4.2c i potwierdza sigma-dywergencję $T F P \mathrm{w}$ tym sektorze.
} 


\subsection{Podsumowanie}

Badania przeprowadzone $\mathrm{w}$ niniejszym rozdziale miały za zadanie przynieść odpowiedzi na wszystkie pytanie szczegółowe postawione we wstępie pracy $\mathrm{w}$ związku z realizacją drugiego jej celu: ocenę czy w Polsce zachodzi proces konwergencji gospodarczej. Odpowiedź na pytanie o konwergencję wśród województw Polski nie jest jednoznaczna, bowiem zależy od miernika aktywności gospodarczej użytego do badań.

W literaturze przedmiotu PKB per capita i wydajność pracy stanowią czasem alternatywne mierniki służące do oceny konwergencji gospodarczej. Tymczasem nie należy ich traktować substytucyjnie, bowiem w badaniach przeprowadzonych w niniejszym rozdziale (w podrozdziale 3.2 ) widoczne były różnice pomiędzy wnioskami formułowanymi na podstawie tych dwóch zmiennych (które pokazywały, że wojewódzkim wydajnościom pracy jest znacznie bliżej do konwergencji niż PKB per capita). Ostatecznie jednak należało stwierdzić, że wśród polskich regionów brak jest istotnej statystycznie konwergencji zarówno PKB per capita, jak i wydajności pracy ${ }^{56}$.

Zupełnie inaczej rzecz się przedstawia $\mathrm{w}$ węższych grupach województw, szczególnie o średnim poziomie zamożności, dla których konwergencja może mieć postać nie tylko doganiania, ale nawet przeganiania obszarów o początkowo lepszej sytuacji pod względem analizowanej zmiennej (co sprawia, że uporządkowanie województw w tej grupie jest pod względem PKB per capita inne w roku 2010 niż 1995). Śledzenie zróżnicowania PKB per capita i wydajności pracy w czasie (sigma-konwergencja) pokazuje, że poziomy wydajności pracy w grupach (klubach) województw podzielonych wg zamożności - wyrównują się. Fakty te potwierdzają, że homogeniczność badanych obszarów ma ogromny wpływ na wnioski co do ich konwergencji oraz, że znacznie łatwiej ją osiągnąć w mniejszych, bardziej jednorodnych grupach (klubach). Zjawisko to widoczne było również w badaniu stanów równowagi wojewódzkiej (które analizowano w podrozdziale 3.3.4), gdzie (przy założeniu różnej dla województw i zmiennej w czasie łącznej produktywności czynników produkcji) wyraźnie zaznaczyła się grupa województw dążących do niższych i wyższych poziomów stanu równowagi (województwo mazowieckie dążyło do osobnego, najwyższego poziomu równowagi).

\footnotetext{
${ }^{56} \mathrm{~W}$ równaniu beta-konwergencji absolutnej można było stwierdzić dywergencję PKB per capita na $15 \%$ poziomie istotności. W równaniu beta-konwergencji warunkowej znaki współczynników wskazywały na (nieistotną statystycznie) dywergencję PKB per capita i konwergencję WDB na pracującego. Natomiast dla obu zmiennych wykazano istotną statystycznie sigma-dywergencję, co świadczy o zwiększeniu zróżnicowania pomiędzy województwami w czasie zarówno PKB per capita, jak i WDB na pracującego.
} 
Badanie regionalnego rozkładu łącznej produktywności czynników produkcji TFP w podrozdziale 3.3 pozwoliło stwierdzić, że wśród województw występuje proces doganiania pod względem postępu technologicznego, tzn. słabiej wyposażone w TFP regiony szybciej go powiększają. Proces ten jest jeszcze szybszy, jeśli założyć można specyficzną dla regionów intensywność inwestycji w B\&R (udział nakładów na B\&R w ogólnych nakładach inwestycyjnych regionu), której wzrost istotnie wpływał na wzrost TFP. Oznacza to, że postęp technologiczny, przynajmniej na terenie danego kraju - może „przenikać” pomiędzy granicami województw. Przypomnijmy, że zwolennicy teorii wzrostu endogenicznego (którego konsekwencją jest dywergencja gospodarcza) spierają się co do źródeł i roli postępu technologicznego we wzroście gospodarczym, ze zwolennikami teorii neoklasycznej (której konsekwencją jest konwergencja). Główny zarzut kierowany do neoklasyków dotyczy faktu, że postęp ten jest generowany wewnątrz gospodarek i nie można go łatwo przenosić, naśladować, czy duplikować. Tymczasem okazuje się, że na terenie jednego kraju, wystarczająco zróżnicowanego, aby dochodziło do dywergencji wzrostu gospodarczego, dochodzi do konwergencji postępu technologicznego. Dzieje się tak głównie w grupie województw najuboższych i o średnim poziomie zamożności - fakt ten dowodzi , że postęp technologiczny jest łatwiej przenosić na niższym poziomie rozwoju (na wyższych poziomach jest on endogeniczny) ${ }^{57}$.

Z badań światowych wynika (por. przykłady z podrozdziału 1.3.3), że większy stopień konwergencji występuje na poziomie zagregowanym niż sektorowym, Nie należało w związku z tym oczekiwać konwergencji wydajności pracy (której brak pokazano na poziomie zagregowanym). Rzeczywiście, w przeciwień-

\footnotetext{
${ }^{57}$ Segmentacja gospodarki (która polega na wytworzeniu w niej innowacyjnego - o wyższym poziomie zaawansowania technologicznego - segmentu wysokiego i nieinnowacyjnego - o niskim poziomie zaawansowania technologicznego - segmentu niskiego została zaliczona w rozdziale 1.1 zarówno do czynników sprzyjających, jak i niesprzyjających konwergencji. W segmencie „wysokim” dominują procesy koncentracji (dywergencji), co w konsekwencji doprowadza do wyraźnej metropolizacji rozwoju tj. koncentrowania się segmentu wysokiego w największych miastach, natomiast konwergencja jest wynikiem dekoncentracji działalności w segmencie „niskim” (por. Gorzelak [2008, s. 77]). Wynika to z faktu, że do prowadzenia działalności „wysokiej” potrzeba nie tylko kapitału, lecz również odpowiedniego otoczenia społecznego i instytucjonalnoinfrastrukturalnego dostępnego głównie w metropoliach. W przypadku segmentu niskiego czynnik ten nie ma takiego znaczenia, a ważnym kryterium lokalizacji przedsiębiorstw stają się niskie koszty produkcji, które sprzyjają przenoszeniu kapitału do uboższych regionów - czyli konwergencji. Wynika z tego, że w gospodarkach o dominującym segmencie niskim, dla którego postęp techniczny nie odgrywa dużego znaczenia (lub może być łatwo imitowany ze względu na opóźnienia rozwojowe regionu) większe jest prawdopodobieństwo zamanifestowania się modelu neoklasycznego i konwergencji. Inaczej będzie w gospodarkach o dominującym segmencie wysokim (o dużym znaczeniu postępu technologicznego), których zaawansowanie technologiczne nie pozwala już na kopiowanie technologii i niejako wymusza ich wytwarzanie, jak zakłada model endogenicznego wzrostu tłumaczący dywergencję gospodarek.
} 
stwie do frakcji pracujących, która, poza rolnictwem, wykazywała zbieżność pozostałych sektorach, wydajność pracy nie wskazywała na podobne tendencje. Taki wniosek (dla wydajności pracy, która jest przecież ilorazem produkcji i liczby pracujących), jest sygnałem, że rozbieżności w wojewódzkiej produkcji dominują nad tendencjami zbieżnymi w zatrudnieniu. Może to oznaczać, że pomimo coraz większej efektywności rozlokowania zasobów pracy, związanej z coraz większą mobilnością i elastycznością branżową polskich pracowników, koncentracja sektorowa produkcji jest zbyt duża, aby doprowadzić do branżowej (sektorowej) konwergencji wydajności pracy.

W związku z konwergencją TFP na poziomie zagregowanym można się było jej spodziewać w, przynajmniej niektórych, sektorach gospodarczych. Rzeczywiście, rozproszenie wiedzy (mierzonej przez TFP) przyczyniającej się do wzrostu GOW, maleje we wszystkich, poza usługami rynkowymi, sektorach. W sektorze usług rynkowych - pomimo, wydawałoby się, łatwego w nich przenikania postępu technologicznego (można przypuszczać, że w sektorze tym postęp ma postać głównie niematerialnych efektów wiedzy) - nie widać tego procesu (konwergencji $T F P$ ). Szukając przyczyn tego zjawiska zauważono, że na przestrzeni analizowanego okresu wyjątkowo wzrosła specjalizacja województwa mazowieckiego w usługach rynkowych. Można z dużym prawdopodobieństwem założyć, że specjalizacja ta związana jest nie tyle z całym województwem, co jego metropolią - Warszawą. Funkcje metropolitarne polegają przecież na pełnieniu działalności usługowej najwyższego rzędu, zwłaszcza o charakterze decyzyjnym, związanej z obecnością instytucji reprezentujących struktury kierowania, zarządzania i kontroli, a te, w ramach działalności reprezentujących usługi rynkowe, przedsiębiorstwa lokalizują w metropolii.

Podsumowując wszystkie badania z tego rozdziału, spróbowano dociec przyczyn stwierdzonych $\mathrm{w}$ nich procesów konwergencji i dywergencji. Boldrin i Canova [2001, s. 211] podają trzy główne czynniki, które mają wpływ na rozwarstwienie regionalnych dochodów: $T F P$, poziom zatrudnienia oraz udział produkcji rolniczej. W przypadku Polski, regionalne zróżnicowanie TFP ma zdecydowanie większy wpływ na zróżnicowanie wydajności pracy niż PKB per capita. Na rozwarstwienie PKB per capita wpływa przede wszystkim zróżnicowanie udziału produkcji rolniczej, i, o czym nie wspominają cytowani autorzy, lecz co pokazały dodatkowe analizy, zróżnicowanie $\mathrm{w}$ udziale produkcji usług rynkowych. A zatem, to rosnące zróżnicowanie udziału produkcji rolnictwa i usług jest jedną z przyczyn (jeśli ograniczyć czynniki wpływające na nierówności dochodowe do wymienionych przez Boldrina i Canovę, to jest główną przyczyną) dywergencji PKB per capita w Polsce. 


\section{Część II}

\section{POLITYKA SPÓJNOŚCI I JEJ WPLYW \\ NA SYTUACJE GOSPODARCZĄ \\ WOJEWÓDZTW I ICH \\ KONWERGENCJE}





\section{ROZDZIAL 4}

\section{PROCESY KONWERGENCJI GOSPODARCZEJ W EUROPIE I NA ŚWIECIE WOBEC REALIZACJI POLITYKI SPÓJNOŚCI}

\subsection{Konwergencja gospodarcza na świecie i w Europie}

Na przestrzeni ostatnich kilkuset lat w skali świata dominował proces zwiększania dystansu pomiędzy krajem o najwyższym i najniższym PKB per capita. Taki wniosek wynika $\mathrm{z}$ analizy danych $\mathrm{z}$ opracowania Angusa Maddisona [2001], gdzie zawarto dane o PKB per capita w okresie od początku naszej ery do czasów współczesnych - por. tabela 4.1.1.

Tabela 4.1.1. PKB per capita $w$ wybranych państwach

\begin{tabular}{|c|c|c|c|c|c|c|c|c|c|c|c|}
\hline $\begin{array}{ll}\text { Państwa } & \text { Rok } \\
\end{array}$ & 1 & 1000 & 1500 & 1600 & 1700 & 1820 & 1870 & 1913 & 1950 & 1973 & 2001 \\
\hline Austria & & & 707 & 837 & 993 & 1218 & 1863 & 3465 & 3706 & 11235 & 20225 \\
\hline Belgia & & & 875 & 976 & 1144 & 1319 & 2692 & 4220 & 5462 & 12170 & 20924 \\
\hline Dania & & & 738 & 875 & 1039 & 1274 & 2003 & 3912 & 6943 & 13945 & 23160 \\
\hline Finlandia & & & 453 & 538 & 638 & 781 & 1140 & 2111 & 4253 & 11085 & 20344 \\
\hline Francja & & & 727 & 841 & 910 & 1135 & 1876 & 3485 & 5271 & 13114 & 21092 \\
\hline Niemcy & & & 688 & 791 & 910 & 1077 & 1839 & 3648 & 3881 & 11966 & 18677 \\
\hline Włochy & & & 1100 & 1100 & 1100 & 1117 & 1499 & 2564 & 3502 & 10634 & 19040 \\
\hline Holandia & & & 761 & 1381 & 2130 & 1838 & 2757 & 4049 & 5996 & 13082 & 21722 \\
\hline Norwegia & & & 640 & 760 & 900 & 1104 & 1432 & 2501 & 5463 & 11246 & 24580 \\
\hline Szwecja & & & 695 & 824 & 977 & 1198 & 1662 & 3096 & 6739 & 13493 & 20562 \\
\hline Szwajcaria & & & 632 & 750 & 890 & 1090 & 2102 & 4266 & 9064 & 18204 & 22264 \\
\hline WielkaBrytania & & & 714 & 974 & 1250 & 1706 & 3190 & 4921 & 6939 & 12025 & 20127 \\
\hline Portugalia & & & 606 & 740 & 819 & 923 & 975 & 1250 & 2086 & 7063 & 14229 \\
\hline Hiszpania & & & 661 & 853 & 853 & 1008 & 1207 & 2056 & 2189 & 7661 & 15659 \\
\hline Europa Zachodnia & 450 & 400 & 771 & 890 & 998 & 1204 & 1960 & 3458 & 4579 & 11416 & 19256 \\
\hline Pozost. kraje europej. & & & 472 & 525 & 584 & 711 & 1027 & 1840 & 2538 & 7614 & 15989 \\
\hline Europa Wschodnia & 400 & 400 & 496 & 548 & 606 & 683 & 937 & 1695 & 2111 & 4988 & 6027 \\
\hline ZSRR & 400 & 400 & 499 & 552 & 610 & 688 & 943 & 1488 & 2841 & 6059 & 4626 \\
\hline USA & & & 400 & 400 & 527 & 1257 & 2445 & 5301 & 9561 & 16689 & 27948 \\
\hline Pozost. kraje zachod. & & & 400 & 400 & 408 & 761 & 2245 & 4752 & 7425 & 13399 & 21718 \\
\hline Meksyk & & & 425 & 454 & 568 & 759 & 674 & 1732 & 2365 & 4845 & 7089 \\
\hline Pozost. kraje Amer.Łac. & & & 410 & 431 & 502 & 663 & 683 & 1424 & 2536 & 4426 & 5508 \\
\hline Ameryka Lacińska & 400 & 400 & 416 & 438 & 527 & 692 & 681 & 1481 & 2506 & 4504 & 5811 \\
\hline Japonia & 400 & 425 & 500 & 520 & 570 & 669 & 737 & 1387 & 1921 & 11434 & 20683 \\
\hline Chiny & 450 & 450 & 600 & 600 & 600 & 600 & 530 & 552 & 439 & 839 & 3583 \\
\hline Indie & 450 & 450 & 550 & 550 & 550 & 533 & 533 & 673 & 619 & 853 & 1957 \\
\hline Pozost. kraje Azji & 450 & 450 & 565 & 565 & 565 & 584 & 643 & 882 & 926 & 2049 & 3998 \\
\hline Azja (bez Japonii) & 450 & 450 & 572 & 575 & 571 & 577 & 550 & 658 & 634 & 1226 & 3256 \\
\hline Afryka & 430 & 425 & 414 & 422 & 421 & 420 & 500 & 637 & 894 & 1410 & 1489 \\
\hline Świat & 445 & 436 & 566 & 595 & 615 & 667 & 875 & 1525 & 2111 & 4091 & 6049 \\
\hline Max/min & 1,1 & 1,1 & 2,8 & 3,5 & 5,2 & 4,4 & 6,4 & 9,6 & 21,8 & 21,7 & 18,8 \\
\hline
\end{tabular}


Z tabeli 4.1.1 można odczytać, że w 1500 r. dystans (mierzony ilorazem pomiędzy krajem o maksymalnym i minimalnym PKB per capita) pomiędzy najbogatszym i najbiedniejszym obszarem wynosił 2,8 (niewiele więcej niż wynosi dystans pomiędzy województwami Polski). W następnych wiekach rósł on do poziomu 5,2 w roku 1700, kiedy to Holandia wysunęła się na europejskiego lidera. W kolejnych 120 latach rozwój pozostałych gospodarek pozwolił na zmniejszenie nierówności do 4,4 w roku 1820, lecz w ciągu następnych stu lat rosły one systematycznie, choć wolno. W roku 1913 dwie potęgi: USA i Chiny reprezentowały dwa przeciwne, o prawie dziesięciokrotnej różnicy, krańce rankingu PKB per capita. Podobna sytuacja wystąpiła po drugiej wojnie światowej, a dzięki bardzo dynamicznemu rozwojowi gospodarki amerykańskiej dystans wzrósł gwałtownie do 21,8. Lata 1950-1973 to okres bardzo dynamicznych wzrostów w Europie: w Niemczech PKB per capita wzrasta o ponad 200\%, lecz pozostałe kraje rozwijały się również dynamicznie (w tych latach obserwowano spadek zróżnicowania wśród państw europejskich z 2,6 do 1,7).

Ostatecznie, należy stwierdzić (zakładając reprezentatywność wybiórczych danych Maddisona), że na przestrzeni ostatnich kilkuset lat w skali świata dominowała dywergencja. Spojrzenie na bardziej szczegółowe i bieżące dane z Penn World Table (gdzie znajdują się informacje o większości światowych gospodarek od roku 1950) potwierdza ten wniosek. Poniżej pokazano zmiany PKB per capita dla tych krajów, dla których były dostępne wszystkie dane w latach 1950-2010 - było ich w sumie 54 ${ }^{1}$. Poniższy wykres pokazuje zależność pomiędzy wartością PKB per capita w 54 krajach świata w roku 1950 i jego wzrostem w roku 2010 - ideę beta-konwergencji absolutnej.

\footnotetext{
${ }^{1} \mathrm{Na}$ kraje te składa się 17 krajów zachodnioeuropejskich oraz wybrane kraje reprezentujące pozostałe kontynenty (dane o krajach środkowo- i wschodnioeuropejskich nie są dostępne dla tak odległych lat analizy).
} 
Wykres 4.1.1.Zależność pomiędzy wartością PKB per capita w 54 krajach świata w roku 1950 i jego wzrostem w roku 2010

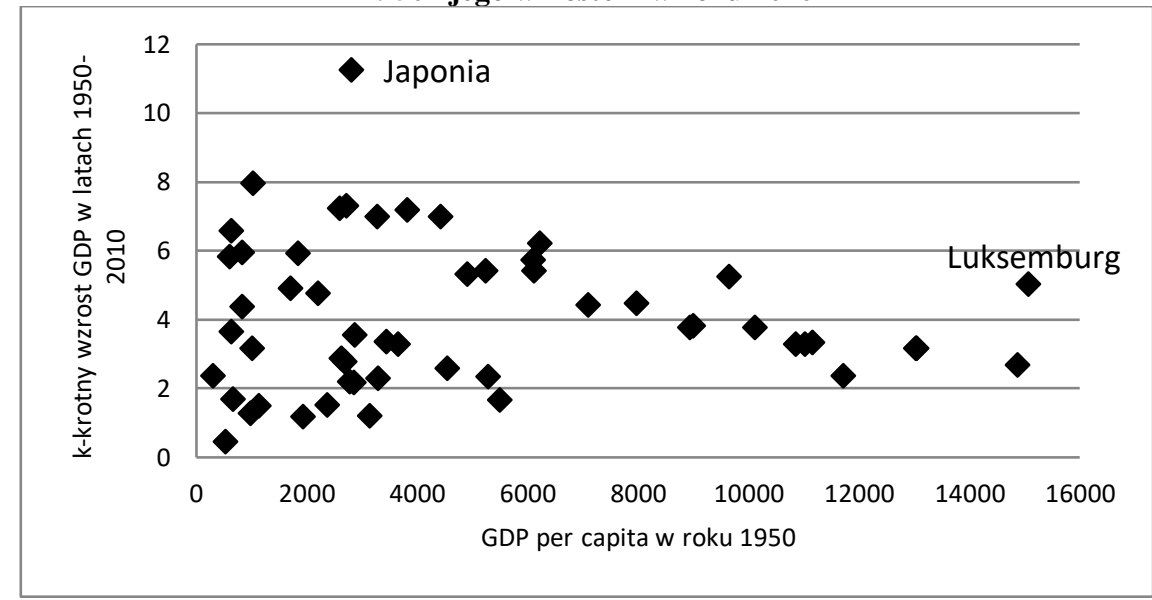

Źródło: opracowanie własne na podstawie danych z Penn World Table 7.1

Wszystkie kraje leżą poniżej linii przeprowadzonej pomiędzy Luksemburgiem i Japonią (Luksemburg o najwyższym, wśród analizowanych 54 krajów, wskaźniku PKB per capita w roku 1950, wykazał stosunkowo mały jego wzrost, zaś Japonia, która w roku 1950 charakteryzowała się stosunkowo niewielkim PKB pc. doświadczyła najintensywniejszego wzrostu gospodarczego). Generalnie nie można dopatrzeć się efektu doganiania (catch-up effect) bogatszych gospodarek przez biedniejsze (który na wykresie powinien być widoczny w postaci ujemnie nachylonej linii przeprowadzonej przez wszystkie punkty reprezentujące zależność pomiędzy początkowym wzrostem PKB i jego tempem wzrostu ${ }^{2}$ ). Na podstawie powyższego wykresu można potwierdzić, że w skali świata brak jest oznak konwergencji gospodarczej ${ }^{3}$.

Wykres 4.1.1 skupia się na wartościach z dwóch lat: 1950 i 2010, pomijając lata pomiędzy tymi datami. Tymczasem w ciągu lat 1950-2010 można wyróżnić co najmniej trzy podokresy, w których wzrost luki rozwojowej pomiędzy krajami świata miał różne nasilenie. Widać to na wykresie 4.1.2, z którego wynika, że brak konwergencji w latach po 1950 r. jest głównie wynikiem procesów, które rozpoczęly się w latach 80 . XX w'.

\footnotetext{
${ }^{2}$ Wspólna dla wszystkich 54 punktów linia regresji wskazuje na niewielkie, lecz dodatnie, nachylenie.

${ }^{3}$ Wniosek ten jest spójny z analizami Barro [1997, s.318] dla 98 krajów świata w latach 19601985.

${ }^{4}$ Różnice w wynikach beta- i sigma-konwergencji nie należą do rzadkości, o czym można się było przekonać na podstawie badań z rozdziału 3.
} 
Wykres 4.1.2. Zróżnicowanie (mierzone współczynnikiem zmienności) pomiędzy 54 krajami świata

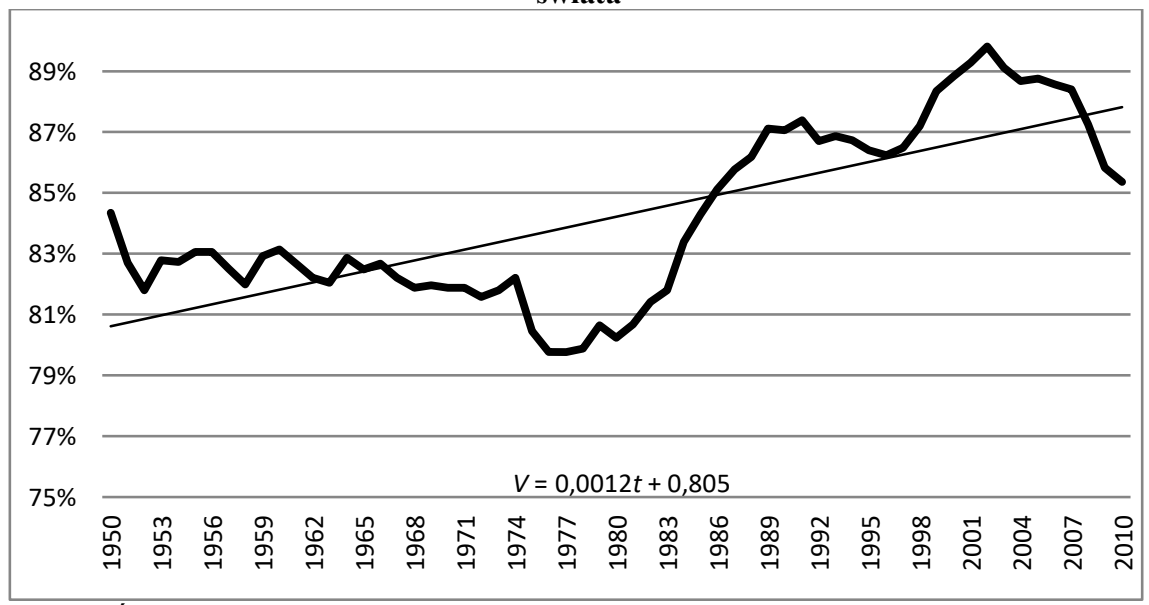

Źródło: opracowanie własne na podstawie danych z Penn World Table 7.1

Dywergencja w skali świata (zarówno typu beta widoczna na wykresie 4.1.1, jak i typu sigma widoczna na wykresie 4.1.2) nie musi oznaczać podobnego procesu wśród węższych, bardziej homogenicznych, grup krajów; na wykresie 4.1.1 dość wyraźnie uwidacznia się grupa punktów (krajów), dla których można byłoby przeprowadzić ujemnie nachyloną linię regresji. Należą do nich kraje zachodnioeuropejskie. W literaturze można spotkać pogląd, że proces doganiania bogatszych krajów przez biedniejsze między państwami zachodnioeuropejskimi trwa już od końca XIX w. ${ }^{5}$, choć tempo konwergencji w ciągu ostatnich 20 lat utrzymywało się na stosunkowo niskim poziomie poniżej $2 \%$ rocznie $^{6}$. Korzystając $\mathrm{z}$ danych $\mathrm{z}$ tabeli 4.1 .1 można częściowo potwierdzić ten pogląd: w roku 1913 dystans pomiędzy gospodarkami europejskimi był mniejszy niż w roku 1870, zaś w roku 1973 - był mniejszy niż w 19507. Analiza bardziej

\footnotetext{
${ }^{5}$ Według M. Ferry’ego [2008, s. 32] proces ten zatrzymał się podczas drugiej wojny światowej, latach 70., oraz w latach 1982-1986.

${ }^{6}$ Jest to wynik uzyskiwany przez wielu badaczy, w szczególności w pracach Sala-i-Martina, choć są opinie, że rezultat ten jest statystycznym ,artefaktem” - por. Monfort [2008, s. 4]. Po raz pierwszy argument ten (nieprawdziwości 2\% tempa zbieżności) przywołał Quach [1996], który sugerował, że stosunkowo stała szybkość konwergencji może być manifestacją znanego w małych próbach obciążenia dla procesów zawierających pierwiastek jednostkowy. We wspomnianym artykule Quach wygenerował niezależne procesy pierwiastka jednostkowego i zastosował do nich test beta-konwergencji. W próbach podobnych do Sala-i-Martina otrzymał podobne, dwuprocentowe tempo zbieżności. Sala-i-Martin [1996, ss.1340-1341] odpiera ten zarzut dowodząc wiarygodności swoich wyliczeń.

${ }^{7}$ W pracy Barro [1997, s. 308-311] znaleźć można analizę gospodarki amerykańskiej dla lat 1840 - 1990. Stwierdzono tam, że od 1840 r. Ameryka, wychodząc od niskiej wartości produktu na 1 zatrudnionego, osiągnęła konwergencję dzięki której, pod koniec XIX w., gospodarka zbliżyła się do ścieżki stanu ustalonego. W kolejnych latach XX w. trzymała się tej ścieżki, co Barro stwierdził na podstawie braku trendu w stopie wzrostu produktu na 1 mieszkańca (jak i realnej stopie
} 
szczegółowych, rocznych, lecz dostępnych dopiero od roku 1950, danych potwierdza, że począwszy od tego roku gospodarki zachodnioeuropejskie (wymienione w tabeli 4.1.1) o początkowo niskim poziomie dochodu wykazywały wyższe tempo wzrostu gospodarczego. Pokazuje to wykres 4.1.3 na którym wyraźnie widać proces doganiania bogatszych gospodarek przez biedniejsze.

Wykres 4.1.3. Zależność pomiędzy początkową wartością a tempem wzrostu PKB per capita w 14 krajach zachodnioeuropejskich wymienionych w tabeli 4.1.1

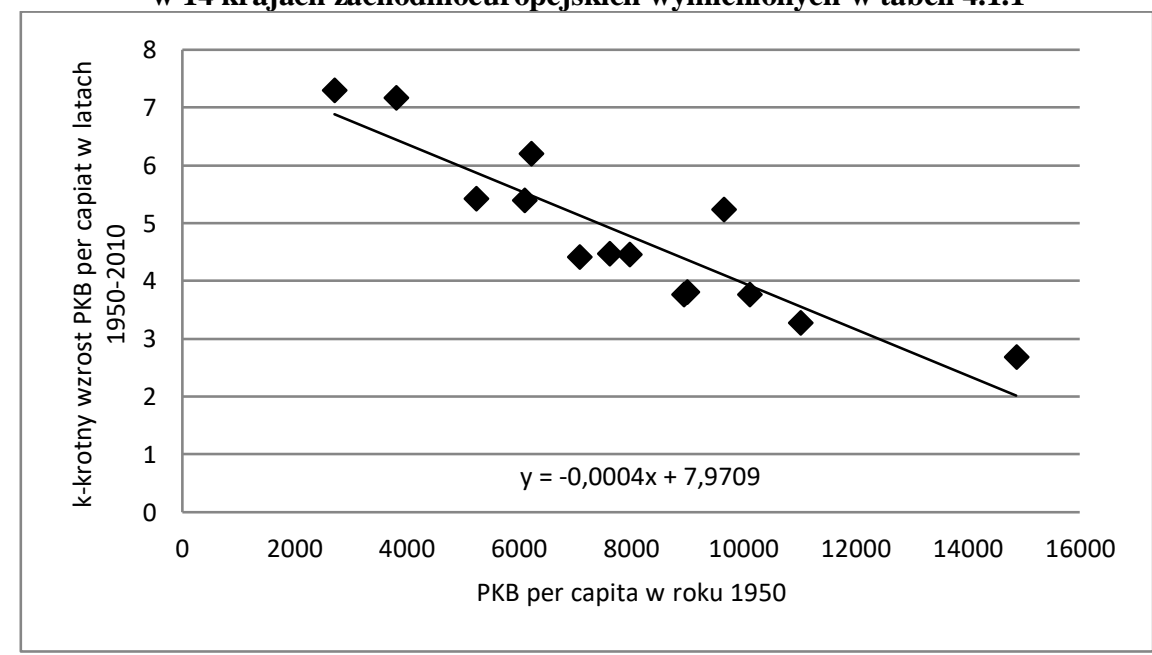

Źródło: opracowanie własne na podstawie danych z Penn World Table 7.1

Z wykresu 4.1.3 wynika, że wśród krajów Europy Zachodniej uwzględnionych na wykresie zachodzi konwergencja. Należy jednocześnie zauważyć, że tego rodzaju konwergencja (tzn. beta-konwergencja absolutna potwierdzająca, że tempo wzrostu gospodarczego zależy, odwrotnie proporcjonalnie, od stanu wyjściowego) nie musi oznaczać zmniejszania się zróżnicowania pomiędzy badanymi krajami (inaczej mówiąc nie musi oznaczać występowania sigmakonwergencji). Tymczasem zbadanie dyspersji pomiędzy PKB per capita gospodarek z wykresu 4.1.3 pokazuje, że o ile w latach 1950-1980 zróżnicowanie malało, to proces ten zatrzymał się w latach 80. XX w.- por. wykres 4.1.4.

procentowej). Regionalne nierówności w Unii Europejskiej są około dwukrotnie wyższe niż w Stanach Zjednoczonych, choć nie zawsze tak było, bowiem po II wojnie światowej nierówności w Stanach były znacznie wyższe. Wynika z tego, że USA znacznie lepiej radzi sobie $\mathrm{z}$ redukowaniem nierówności niż Europa. Przykład Ameryki pokazuje, że wolny handel, wspólna polityka fiskalna i monetarna, mobilność czynników produkcji sprzyjają konwergencji (por. Boldrin, Canova, [2001, s. 207]). 
Wykres 4.1.4. Zróżnicowanie (mierzone współczynnikiem zmienności) pomiędzy 14 krajami Europy Zachodniej

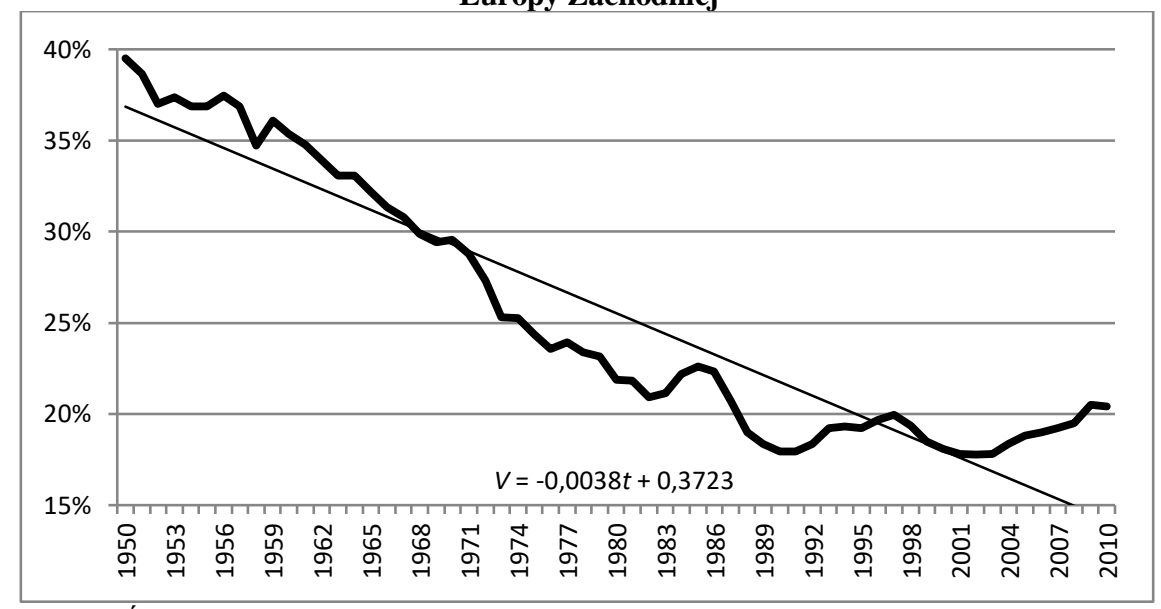

Źródło: opracowanie własne na podstawie danych z Penn World Table 7.1

Próba dołączenia do analiz krajów Europy Wschodniej napotyka na trudność związaną z dostępem do danych statystycznych obejmujących podobnie długi, co dla krajów Europy Zachodniej, okres. Dlatego porównania obejmujące Blok Wschodni będą dotyczyć okresu od roku 1997, od którego w bazach danych Eurostatu znajdują się dane nt. wszystkich krajów europejskich. W tabeli 4.1.2 pokazano wartości PKB per capita wszystkich krajów europejskich, gdzie w ostatnim wierszu znajduje się iloraz pomiędzy maksymalną i minimalną wartością PKB per capita analizowanych krajów. Dane te pokazują, że w roku 1997 różnica pomiędzy gospodarką najbiedniejszą (Bułgaria) i najbogatszą (Luxemburg) była ponad 8,13-krotna, podczas gdy w roku 2010 różnica ta była 7,79-krotna (Yugosławia-Luxemburg). Jednocześnie gospodarka najuboższa w 1997 r. Bułgaria zanotowała 2,5-krotny wzrost PKB per capita, zaś gospodarka wówczas najbogatsza - Luksemburg - „tylko” 1,9-krotny. Generalnie, większość krajów Europy Środkowej i Wschodniej wymienionych na początku tabeli 4.1.2 zanotowała wyższy wzrost gospodarczy niż kraje Europy Zachodniej. 
Tabela 4.1.2. PKB per capita w tys. pps dla krajów Europy (uporządkowanych wg wartości PKB per capita w roku 1997)

\begin{tabular}{|c|c|c|c|}
\hline Kraje $\quad$ Lata & 1997 & 2010 & 2010/1997 \\
\hline Bułgaria & 4,3 & 10,6 & 2,5 \\
\hline Jugosławia & 4,3 & 8,6 & 2,0 \\
\hline Rumunia & 4,8 & 11,0 & 2,3 \\
\hline Turcja & 5,3 & 11,8 & 2,2 \\
\hline Łotwa & 5,6 & 12,6 & 2,3 \\
\hline Litwa & 6,3 & 14,2 & 2,3 \\
\hline Estonia & 6,8 & 15,7 & 2,3 \\
\hline Polska & 7,6 & 15,3 & 2,0 \\
\hline Chorwacja & 8,2 & 15,0 & 1,8 \\
\hline Słowacja & 8,3 & 18,1 & 2,2 \\
\hline Węgry & 8,5 & 15,5 & 1,8 \\
\hline Czechy & 12,3 & 20,1 & 1,6 \\
\hline Portugalia & 12,7 & 19,8 & 1,6 \\
\hline Słowenia & 12,7 & 20,9 & 1,6 \\
\hline Malta & 13,1 & 20,2 & $\mathbf{1 , 5}$ \\
\hline Grecja & 13,7 & 21,5 & 1,6 \\
\hline Cypr & 13,8 & 23,8 & 1,7 \\
\hline Hiszpania & 15,1 & 24,5 & 1,6 \\
\hline Finlandia & 17,9 & 28,3 & 1,6 \\
\hline Francja & 18,6 & 26,1 & 1,4 \\
\hline Irlandia & 18,8 & 31,1 & 1,7 \\
\hline UK & 19,2 & 27,8 & 1,4 \\
\hline Włochy & 19,4 & 24,5 & 1,3 \\
\hline Niemcy & 20,1 & 28,7 & 1,4 \\
\hline Szwecja & 20,1 & 30,1 & 1,5 \\
\hline Belgia & 20,4 & 29,0 & 1,4 \\
\hline Holandia & 20,6 & 32,6 & 1,6 \\
\hline Austria & 21,4 & 30,8 & 1,4 \\
\hline Dania & 21,6 & 30,7 & 1,4 \\
\hline Islandia & 22,3 & 26,9 & 1,2 \\
\hline Norwegia & 23,9 & 44,2 & 1,8 \\
\hline Szwecja & 24,4 & 36,1 & 1,5 \\
\hline Luxemburg & 35,0 & 67,0 & 1,9 \\
\hline $\min$ & 4,3 & 8,6 & \\
\hline $\max$ & 35,0 & 67,0 & \\
\hline $\max / \min$ & 8,1 & 7,8 & \\
\hline
\end{tabular}

Źródło: opracowanie własne na podstawie danych z Eurostatu

Aby stwierdzić, czy proces doganiania widoczny na wykresie 4.1.3 dla krajów Europy Zachodniej dotyczy całej Europy, na wykresie 4.1.5 przedstawiono zależność pomiędzy wartością PKB per capita w roku 1997, a jego wzrostem w roku 2010 dla wszystkich krajów europejskich (choć wykresów 4.1.3 i 4.1.5 nie można wprost porównywać, bowiem dotyczą one innych zakresów czasowych analizy). Na wykresie 4.1.5 widać odwrotnie proporcjonalną zależność pomiędzy początkową wartością PKB pc. a jego tempem wzrostu, co znajduje odbicie w ujemnym współczynniku linii regresji. Z wykresu usunięto jedynie 
Luxemburg, który był gospodarką zdecydowanie „odstającą” (zabieg ten spowodował zwiększenie $\mathrm{R}^{2}$ linii regresji z 0,48 do wartości 0,71 ).

Wykres 4.1.5. Zależność pomiędzy początkową wartością a tempem wzrostu PKB per capita dla 32 krajów Europy

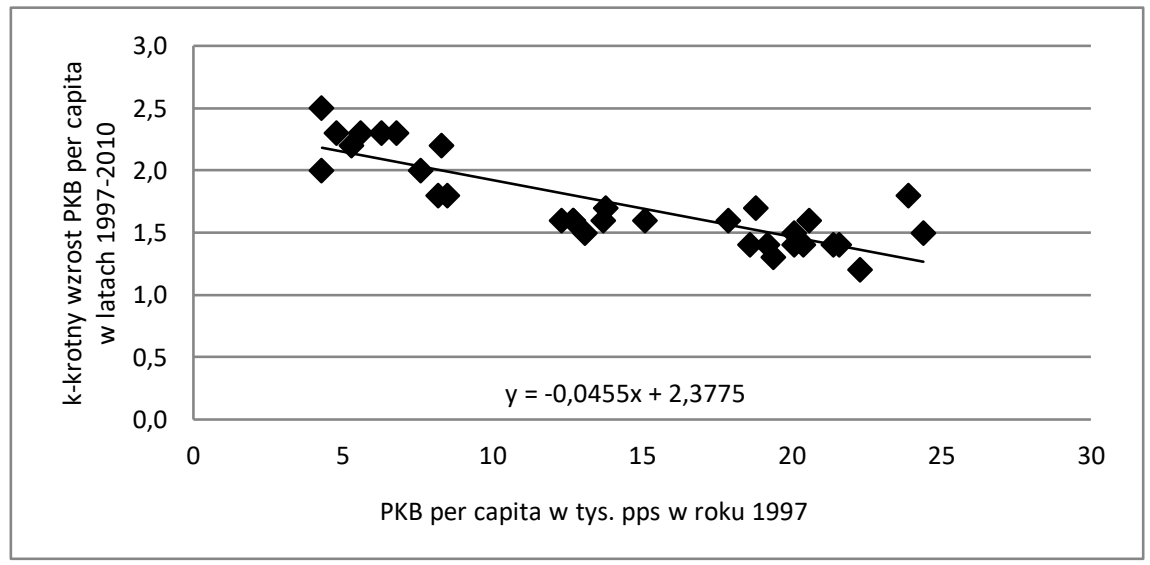

Źródło: opracowanie własne na podstawie danych z Eurostatu

Wykres 4.1.5 świadczy o tym, że doganianie gospodarek bogatszych przez uboższe występuje w całej Europie, co więcej, odbywa się to przy jednoczesnym zmniejszaniu nierówności w czasie, czego dowodem jest wykres 4.1.6. Procesu takiego nie można było stwierdzić dla państw Europy Zachodniej, bowiem to dołączenie krajów Europy Środkowo-Wschodniej pozwala stwierdzić konwergencję, choć odbywa się to kosztem znaczącego podniesienia poziomu nierówności (z 20\% w 1997 r. dla 14 państw Europy Zachodniej do 46\% dla 32 krajów całej Europy).

Wykres 4.1.6. Zróżnicowanie (mierzone współczynnikiem zmienności) pomiędzy 32 krajami

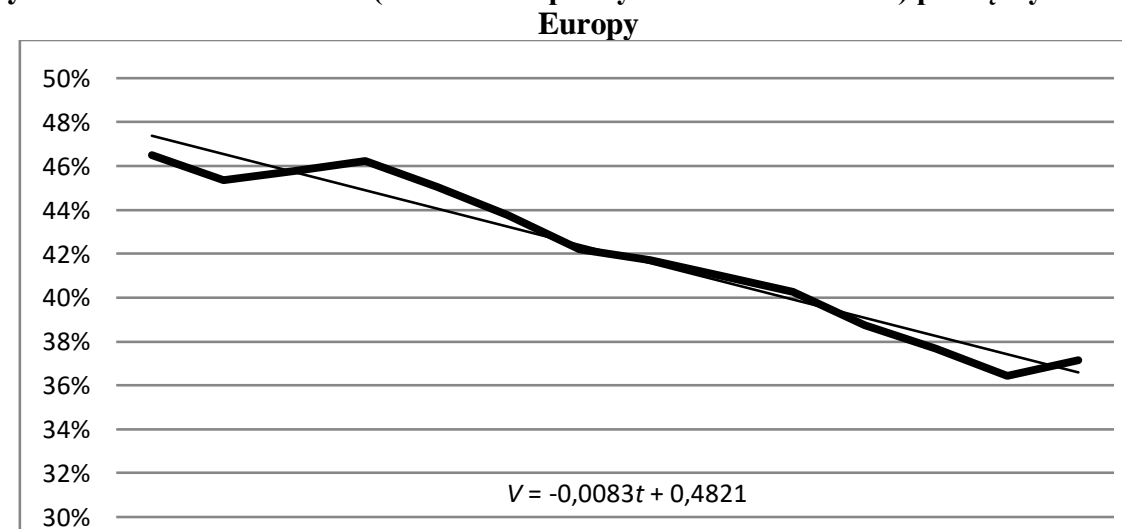

19971998199920002001200220032004200520062007200820092010

Źródło: opracowanie własne na podstawie danych z Eurostatu 
Podsumowując, można stwierdzić, że na przestrzeni ostatnich kilkuset lat w skali świata dominowała dywergencja. Analiza danych po roku 1950 pokazuje, że o ile w dalszym ciągu brak jest konwergencji w skali świata, to efekt doganiania występuje wśród gospodarek europejskich. O ile jednak dla państw Europy Zachodniej zatrzymał się on w latach 80. XX w., to dla całej Europy trwa do dzisiaj. Na dzisiejszą konwergencję gospodarczą Europy mają wpływ głównie gospodarki państw Europy Środkowo-Wschodniej, których włączenie zwiększyło znacznie poziom nierówności wśród wszystkich państw europejskich lecz odwróciło trend nierówności gospodarczych państw objętych transformacją w kierunku konwergencji. Poniżej zawężono gospodarki europejskie do grupy tworzących Unię Europejską i realizujących wspólne polityki.

\subsection{Polityka spójności jako odpowiedź na rosnące nierówności gospodarcze w UE}

5 marca 1957 roku w Rzymie odbyła się konferencja międzyrządowa w sprawie wspólnego rynku i Euroatomu rozpoczynająca historię Unii Europejskiej (choć pod tą nazwą Unia funkcjonuje dopiero od początku lat $90 .{ }^{8}$ ). Na konferencji tej podpisano „Traktat ustanawiający Europejską Wspólnotę Gospodarczą"9 EWG. Traktat Rzymski, bo o nim mowa, sygnowany został przez przedstawicieli 6 krajów: Belgii, Francji, Holandii, Luksemburga, Republiki Federalnej Niemiec (RFN) oraz Włoch ${ }^{10}$. Zadaniem EWG było utworzenie wspólnego rynku oraz stopniowe ujednolicanie polityki gospodarczej państw będących członkami Wspólnoty, ciągłej oraz zrównoważonej ekspansji, stabilizacji, podwyższania poziomu życia, jak również ściślejszych stosunków między państwami członkowskimi ${ }^{11}$. Zagadnienie osiągania spójności ekonomicznej i społecznej w Europie - głównego postulatu dzisiejszej polityki spójności miało wówczas postać wzmianki w preambule do Traktatu Rzymskiego (por. Rodrigues-Pose i Fratesi [2004, s. 5]). Od początku istnienia Wspólnoty zakła-

\footnotetext{
8 Traktat o Unii Europejskiej, ustanawiający nową nazwę dla Wspólnoty Europejskiej, został przyjęty na spotkaniu 9-10 grudnia 1991 roku w Maastricht (stąd jego inna nazwa: traktat z Maastriich). Ostatecznie traktat został podpisany 7 lutego 1992 r., a wszedł w życie 01.01.1993 r. - stąd różne daty w źródłach informujących o oficjalnej zmianie nazwy Wspólnoty Europejskiej na Unię Europejską.

${ }^{9} \mathrm{Z}$ nazwy tej wykreślono później przymiotnik gospodarcza, zmieniając nazwę dokumentu na „Traktat o ustanowieniu Wspólnoty Europejskiej”. Drugą umową wieńczącą wspomnianą konferencję był Traktat ustanawiający Europejską Wspólnotę Energii Atomowej (Euroatom). Obydwa traktaty noszą nazwę rzymskich, a ich tekst w języku polskim można znaleźć np. na: http://polskawue.gov.pl/files/polska_w_ue/prawo/traktaty/Traktaty_rzymskie.pdf.

${ }^{10}$ A dokładnie podpisy złożyli reprezentanci Rządu Królestwa Belgii, RFN, Francji, Włoch oraz Wielkiego Księstwa Luksemburga i Królestwa Niderlandów.

${ }^{11}$ Por. Łastawski [2006, ss. 116-119], na podstawie „Traktatu w sprawie utworzenia Europejskiej Wspólnoty Gospodarczej”.
} 
dano, iż będzie ona poszerzała się o kolejne państwa (choć początkowo kraje tzw. „szóstki” niechętnie przychylały się do wniosków akcesyjnych, niemniej rozszerzenia stały się faktem). W wyniku pierwszego rozszerzenia w 1973 r. do Wspólnoty przyjęto Wielką Brytanię, Danię oraz Irlandię. 1 stycznia 1981 roku przyłączono Grecję, zaś 5 lat później, w 1986 - Hiszpanię i Portugalię. Czwarte rozszerzenie w 1995 r. dotyczyło Austrii, Finlandii i Szwecji. Dotychczasowe rozszerzenia Unii ${ }^{12}$ miały formalnie miejsce w pierwszym dniu danego roku, dlatego data największego rozszerzenia - z 1 maja 2004 r. - aż o 10 nowych krajów była pewnym wyjątkiem. Kolejne i ostatnie, jak dotąd, rozszerzenie Wspólnoty miało miejsce 01.01.2007 roku, kiedy to przyjęto Bułgarię oraz Rumunię.

Początkowo (tzn. do początku lat 80.) polityka rozwoju regionów nie zajmowała wiele miejsca w politykach Wspólnoty (w 1980 r. przeznaczano na nią zaledwie $11 \%$ całości budżetu). Należy jednakże zauważyć, że aż do tego czasu rozbieżności w poziomie dochodu poszczególnych krajów tworzących Wspólnotę nie stanowily problemu, bowiem nie tylko nie narastały, lecz malały - por. wykres 4.2.1.

Wykres 4.2.1. Zróżnicowanie (mierzone współczynnikiem zmienności) PKB per capita pomiędzy krajami tworzącymi Wspólnotę Europejską w różnych momentach jej istnienia

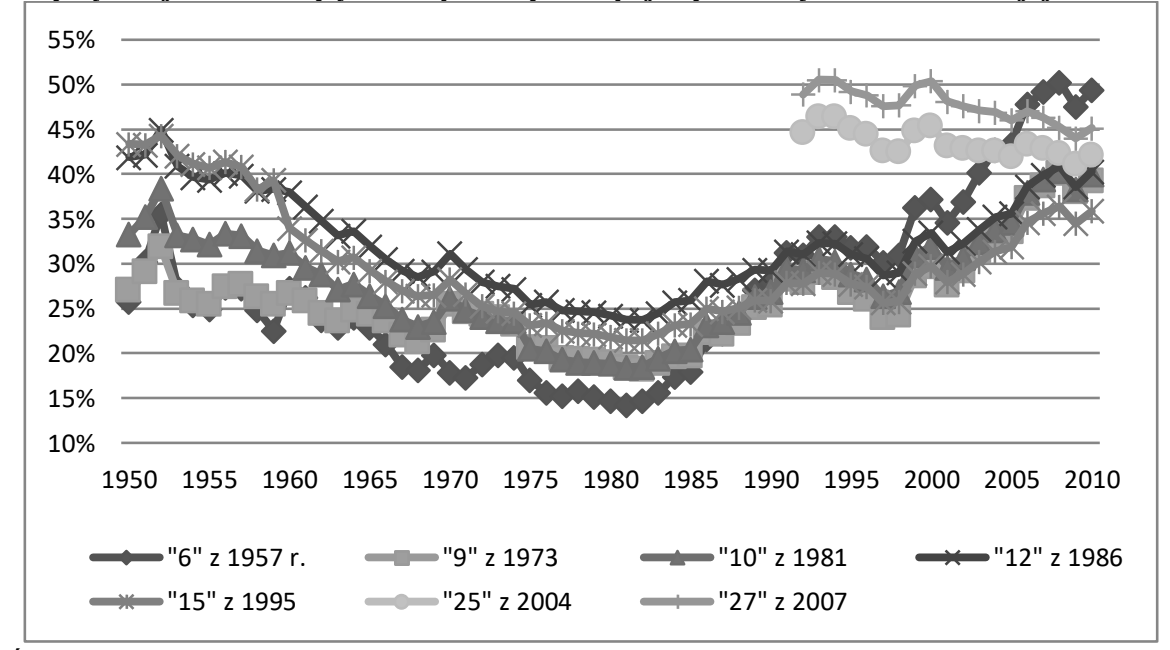

Źródło: opracowanie własne na podstawie danych Ameco (od 1960) i Penn World Table (lata 1950-1959)

Widoczny na wykresie 4.2.1 rosnący trend od lat 80 . we współczynniku mierzącym nierówności w dochodzie per capita krajów Wspólnoty Europejskiej, jak i wzrost poziomu tego współczynnika po kolejnych rozszerzeniach stworzyły

12 W których pominięto niepełne rozszerzenia, jak np. o Wschodnie Niemcy z 3 października $1990 \mathrm{r}$. 
potrzebę działań skierowanych na przygotowanie słabiej rozwiniętych państw i regionów do spełnienia warunków członkostwa. W tym celu w 1989 r. dokonano reformy funduszy strukturalnych polegającej na przebudowie zasad ich przydzielania, jak i przeznaczanego na nie budżetu (którego udział wzrósł dwukrotnie na przestrzeni zaledwie kilku lat: 1988-1992). Ostatecznie, wynikiem reformy było skoordynowanie działań finansowanych w ramach trzech funduszy (EFRR, EFS, EFOiG) oraz utworzenie nowego Funduszu Spójności (w celu złagodzenia obciążeń krajów przystępujących do Unii Gospodarczej i Walutowej). Po przeprowadzaniu reformy, ponad $2 / 3$ wydatków $\mathrm{z}$ funduszy strukturalnych skoncentrowanych było w tzw. regionach zaliczanych do celu 1 , którego nazwy zmieniały się w różnych okresach programowania, lecz zawsze dotyczył on wyrównywania nierówności gospodarczych ${ }^{13}$. Kryterium kwalifikacji regionów do objęcia funduszami przeznaczanymi na realizację celu 1 , to regiony, których PKB per capita mierzone według parytetu siły nabywczej nie przekracza 75\% średniej unijnej. Taka koncentracja środków oznaczała istotny zastrzyk funduszy dla krajów objętych tych celem. Liczba regionów Celu 1 w kolejnych okresach programowania rosła; w 1989 należały do niego 44 regiony (wszystkie regiony Grecji, Portugalii i Irlandii, południe Włoch, południowo-zachodnie regiony Hiszpanii, a po zjednoczeniu Niemiec landy byłej NRD i wschodni Berlin), zaś w okresie programowania 2000-2006 było to już 167 regionów (por. Rodrigues, Fratesi [2004, s. 8]). Z wykresu 4.2.1 wynika, że od roku 2004 r. polityka regionalna UE stanęła przed największym wyzwaniem od początku funkcjonowania; przyjęcie 10 nowych krajów odwróciło rosnący od lat 80. trend w nierównościach dochodowych w UE, lecz kosztem wzrostu ich poziomu. Wzrost nierówności regionalnych (na poziomie NUTS 2) był nawet większy, o czym szerzej traktuje rozdział 4.3.

\subsection{Konwergencja regionalna i wewnętrzna}

Obserwowane w Europie różnice regionalne (na poziomie NUTS 2) są większe niż na poziomie krajów (NUTS 0); w 2001 r. w regionie o najniższym PKB per capita wśród państw kandydujących, czyli w województwie lubelskim, odnotowano zaledwie $28,6 \%$ poziomu średniej UE - dziewięciokrotnie mniej niż w Londynie (za: Geodecki [2006, s. 84]). W krajach „starej” Unii PKB per capita najuboższego w 1995 r. regionu (w Hiszpanii) stanowiło 58,5\% średniej unijnej, a PKB per capita najbogatszego regionu było 7-mio krotnie wyższe. Różnice regionalne w Unii Europejskiej nie są jednakże duże w porównaniu do innych regionów świata. Według badań Shankar i Shar [2003, ss. 1426-1428]

\footnotetext{
${ }^{13}$ W latach 1988-1993 cel 1 polityki spójności miał nazwę „,wspieranie rozwoju i dostosowanie strukturalne regionów słabo rozwiniętych (zacofanych)”, w latach 1994-1999: „,rozwój i strukturalne dostosowanie regionów zacofanych”, w latach 2000-2006: „wsparcie regionów zapóźnionych w rozwoju”, a ostatnim okresie programowania 2007-2013 cel 1 nosi nazwę „konwergencja”.
} 
w 1996 r. iloraz pomiędzy najbogatszym i najbiedniejszym regionem w Wietnamie wynosił 24,7, w Rosji 21,3, w Chinach i Indonezji był on ponad 11-stokrotny.

W przypadku Unii Europejskiej zróżnicowanie regionalne wśród nowych członków jest zdecydowanie wyższe niż wśród regionów starej 15 -stki - por. wykres 4.3.1 $1^{14}$. Z punktu widzenia procesów konwergencji interesujący jest jednak nie tyle poziom nierówności, co ich dynamika. Podobnie do krajów (por. wykres 4.2.1), proces konwergencji regionalnej zachodzi dla wszystkich regionów Unii (środkowa linia na wykresie 4.3.1), choć nie zachodzi wśród regionów krajów starej $15-$ stki $^{15}$. Niewielki spadek zróżnicowania wśród regionów nowych członków Unii, widoczny od 2005 r. (najwyższa linia na wykresie 4.3.1) może być konsekwencją realizacji w tych regionach polityki spójności. Jednocześnie jednak wewnątrz wielu krajów obserwowano procesy polaryzacyjne, o czym szerzej traktuje podrozdział 4.3.1.

\section{Wykres 4.3.1. Zróżnicowanie (mierzone współczynnikiem zmienności) PKB per capita} wśród różnych grup regionów Unii Europejskiej ${ }^{16}$

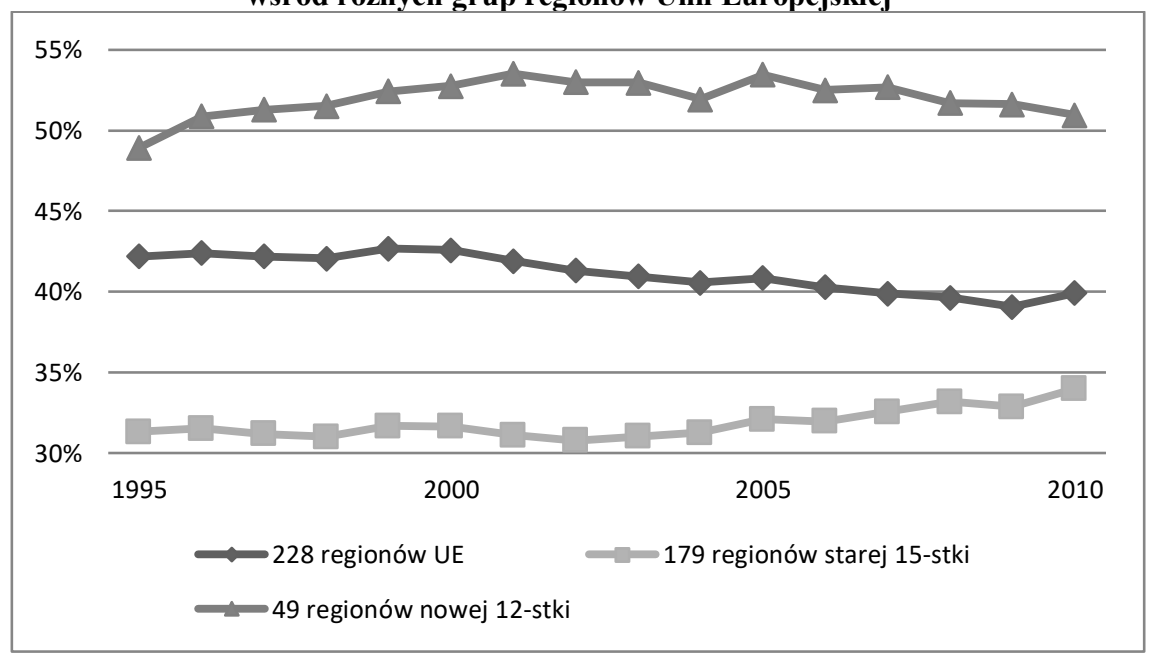

Źródło: opracowanie własne na podstawie danych o PKB per capita w pps z Eurostatu

\footnotetext{
${ }^{14}$ Podobna analiza przeprowadzona dla danych z lat 1995-2001 w artykule Geodecki [2006, s. 84] wskazała również na wyraźniejszy proces konwergencji dla nowych członków (wówczas jedynie zabiegających o akcesję) niż dla krajów starej 15-stki.

${ }^{15}$ Choć brak konwergencji regionalnej jest obserwowany dopiero od lat 80 . XX w., czego nie widać na wykresie 4.3.1, a co potwierdzają badania prowadzone w latach 90. przez Barro i Sala-iMartina [1991], [1992], Mankiwa i in. [1992], które wskazywały że wówczas pomiędzy wszystkimi regionami Europy występowała konwergencja.

${ }^{16}$ Ze względu na brak danych o regionalnym PKB per capita w pierwszych latach analizy: 19951999 dla Węgier, Włoch, Austrii i Finlandii pominięto regiony tych krajów.
} 


\subsubsection{Hipoteza Williamsona i konwergencja wewnętrzna}

Jak wspomniano powyżej, po rozszerzeniu Unii o nowych członków w 2004 r., nierówności gospodarcze pomiędzy krajami znacznie wzrosły, lecz z roku na rok są coraz mniejsze. Tymczasem badanie nierówności wewnątrz poszczególnych krajów nie pokazuje ich zmniejszania - por. tabela 4.3.1.1 ${ }^{17}$.

Tabela 4.3.1.1. Średnioroczne tempo zmian (wyliczone dla okresu podanego w drugiej kolumnie) wyliczone na podstawie wykładniczego modelu trendu zastosowanego do wspólczynnika zmienności regionalnych $P K B$ per capita

\begin{tabular}{|c|c|c|}
\hline Kraj & Okres & $\begin{array}{c}\text { Średnioroczne tempo zmian (w \%) nie- } \\
\text { równości regionalnych }\end{array}$ \\
\hline Austria & $2000-2010$ & $-1,2$ \\
\hline Belgia & $1995-2010$ & $-1,3$ \\
\hline Bułgaria & $1995-2010$ & 9 \\
\hline Czechy & $1995-2010(2003-2010)$ & $1,6(1,1)$ \\
\hline Dania & $1995-2010$ & 1 \\
\hline Finlandia & $2000-2010$ & 2,1 \\
\hline Francja & $1995-2010(1995-2006)$ & $0,6(0,1)$ \\
\hline Grecja & $1995-2010(1995-2004)$ & $4,4(-4,4)$ \\
\hline Hiszpania & $1995-2010$ & $-1,3$ \\
\hline Holandia & $1995-2010$ & 1,8 \\
\hline Irlandia & $1995-2010$ & 1,4 \\
\hline Niemcy & $1995-2010$ & $-0,4$ \\
\hline Polska & $1995-2010$ & 1,6 \\
\hline Portugalia & $1995-2010$ & 0,6 \\
\hline Rumunia & $1995-2010$ & 3,3 \\
\hline Słowacja & $1995-2010$ & 1,6 \\
\hline Słowenia & $1995-2010$ & 0,9 \\
\hline Szwecja & $1995-2010$ & $-1,1$ \\
\hline W.Brytania & $1995-2010$ & 0,3 \\
\hline Węgry & $2000-2010$ & 2 \\
\hline Włochy & $2000-2010(2006-2010)$ & $-0,2$ \\
\hline Zrodt: & 1902 & \\
\hline
\end{tabular}

Źródło: obliczenia własne na podstawie danych o regionalnych PKB per capita z Eurostatu

Z tabeli 4.3.1.1 wynika, że większość krajów odnotowała wzrost nierówności wewnętrznych; najsilniejszy był on w Bułgarii, Grecji (dla której jest to wynik sytuacji po 2004 r.) i Rumunii. Niewiele krajów zanotowało spadek (średni) nierówności; spośród 21 krajów z tabeli 4.3.1.1 było takich tylko $4^{18}$ : Austria, Belgia Hiszpania, Szwecja, w których spadek nierówności miał podobną wartość: $1,1-1,3 \%$ rocznie (co ciekawe, gdyby wyłączyć $\mathrm{z}$ analizy ostatnie lata, to Grecja, która wskazywana była wśród krajów o największym wzroście dysproporcji dochodowych, byłaby krajem w którym regionalne nierówności zmniejszały się najszybciej).

\footnotetext{
${ }^{17}$ W tabeli nie przedstawiono danych dla Estonii, Łotwy, Cypru, Litwy, Luksemburga, Malty bowiem w krajach tych występuje tylko jeden region NUTS 2.

${ }^{18}$ Nie policzono tutaj Włoch i Niemiec, dla których uzyskano wprawdzie ujemne tempo wzrostu nierówności, lecz tak niewielkie, że należy stwierdzić brak zmian.
} 
Z porównania danych z tabeli 4.3.1.1 oraz wykresów 4.1.6 i 4.3.1 wynika, że o ile można dopatrzeć się większej spójności gospodarczej pomiędzy krajami europejskimi, to nie zawsze towarzyszy temu podobny proces wewnątrz badanych gospodarek (brak jest konwergencji wewnętrznej). Jest to dość typowa dla Unii Europejskiej rozbieżność (o której pisano w podrozdziale 1.3.4) - zmniejszanie zróżnicowania pomiędzy gospodarkami poszczególnych krajów, przy utrwalaniu, lub nawet pogłębianiu zróżnicowań na poziomie regionów (zob. Yuill [2008, s. 33-35]). Jest to szczególnie niepokojący symptom wśród krajów-beneficjentów polityki spójności, której środki są wydatkowane właśnie na zmniejszanie różnic wśród regionów NUTS 2. Brak konwergencji wewnętrznej wśród krajów-beneficjentów, spowodował, że Komisja Europejska przyjęła do wiadomości fakt pewnej wymiany pomiędzy procesem konwergencji na narodowym i regionalnym szczeblu (por. Perez [2009, s. 512]). Zjawisko to thumaczone było m.in. tym, że wewnątrzkrajowe nierówności dotyczące zróżnicowania dochodu pomiędzy regionami są przejściowe, a ze zjawiskiem konwergencji wewnętrznej spotkać się można dopiero na wyższych etapach rozwoju poszczególnych gospodarek. Jest to pogląd znany pod nazwą hipotezy Williamsona [1965]. Teorię tę opisano w podrozdziale 1.3.4, a poniżej zweryfikowano ją w odniesieniu do krajów-członków Unii Europejskiej.

Zgodnie ze wzorem (1.3.4.1), empirycznej weryfikacji hipotezy Williamsona dokonać można za pomocą estymacji parametrów funkcji mającej postać wielomianu drugiego stopnia:

$$
y_{t}=\alpha_{0}+\alpha_{1} x_{t}+\alpha_{2} x_{t}^{2}
$$

gdzie: $y_{t}$ - miara dyspersji PKB per capita dla regionów NUTS $2 \mathrm{w}$ danym kraju notowana przez Eurostat ${ }^{19}, x_{t}$ - krajowe PKB per capita $\left(P K B \_p c\right) \mathrm{w}$ cenach stałych w roku $t, t=1995, \ldots, 2009$.

Poniżej pokazano efekty szacowania powyższego równania (w postaci jedynie znaków i istotności estymatorów) dla krajów-członków Unii Europejskiej.

\footnotetext{
${ }^{19}$ Jest to suma absolutnych różnic pomiędzy regionalnym i narodowym PKB per capita, ważona udziałem populacji, zob. http://appsso.eurostat.ec.europa.eu/nui/show.do?dataset=nama_r_e0digdp\&lang=en.
} 
Tabela 4.3.1.2. Znaki estymatorów parametrów równania: $y=\alpha_{0}+\alpha_{1} x+\alpha_{2} x^{2 *}$

\begin{tabular}{|c|c|c|}
\hline $\begin{array}{c}\text { Kraj } \\
\text { (rok przystąpienia do UE) }\end{array}$ & Oszacowanie przy $P K B \_p c$ & Oszacowanie przy $P K B \_p c^{2}$ \\
\hline \multicolumn{3}{|l|}{ Grupa 1} \\
\hline Belgia (57) & $+* * *$ & $-* * *$ \\
\hline Niemcy (57) & $+* * *$ & $-* * *$ \\
\hline Holandia (57) & $+* *$ & $-* *$ \\
\hline Hiszpania (86) & $+* * *$ & $-* * *$ \\
\hline Finlandia (95) & $+* * *$ & $-* * *$ \\
\hline \multicolumn{3}{|l|}{ Grupa 2} \\
\hline Czechy (04) & $+* * *$ & $-* * *$ \\
\hline Polska (04) & $+* * *$ & $-* * *$ \\
\hline Wielka Brytania (73) & $+* *$ & $-* *$ \\
\hline Irlandia (73) & $+* *$ & $-*$ \\
\hline \multicolumn{3}{|l|}{ Grupa 3} \\
\hline Rumunia (07) & + & - \\
\hline Słowenia (04) & + & - \\
\hline Słowacja (04) & $+^{*}$ & - \\
\hline Szwecja (95) & $++^{*}$ & $-*$ \\
\hline \multicolumn{3}{|l|}{ Grupa 4} \\
\hline Bułgaria (07) & - & $+^{*}$ \\
\hline Dania (73) & - & + \\
\hline Grecja (81) & - & $+*$ \\
\hline Francja (57) & - & + \\
\hline \multicolumn{3}{|l|}{ Grupa 5} \\
\hline Portugalia (86) & + & + \\
\hline
\end{tabular}

$\mathrm{Z}$ tabeli 4.3.1.1 wynika, że zróżnicowanie wewnętrzne PKB per capita w większości analizowanych krajów można opisać za pomocą krzywej w kształcie odwróconego $\mathrm{U}$ (na co wskazuje dodatni znak przy $x$ i ujemny przy $x^{2}$ ). Szczególnie interesujące są oszacowania funkcji 4.3.1.1 dla Polski, gdzie zróżnicowanie PKB per capita co prawda rośnie (por. tabela 4.3.1.1), lecz wartości estymatorów z tabeli 4.3.1.2 wskazują, że może ono niebawem osiągnąć swoje maksimum, po czym, jeśli założyć prawdziwość hipotezy Williamsona, powinno zacząć spadać ${ }^{20}$. Fakt, że zróżnicowanie dochodów w większości analizowanych krajów można opisać za pomocą krzywej parabolicznej w kształcie od-

\footnotetext{
${ }^{20} \mathrm{~W}$ ten sposób równanie 4.3.1.1 można wykorzystać do tworzenia prognoz zróżnicowania regionalnego - prognoz konwergencji wewnętrznej. Przyszłe wartości zmiennej objaśniającej (przyszłe wartości krajowego PKB per capita) można ustalić na podstawie prognoz wzrostu gospodarczego sporządzanych przez różne instytucje (np. Ministerstwo Finansów stosunkowo często aktualizuje Wytyczne dotyczące stosowania jednolitych wskaźników makroekonomicznych będacych podstawa oszacowania skutków finansowych projektowanych ustaw, w których zamieszcza prognozy wzrostu PKB, które wraz z prognozami demograficznymi GUS, mogą posłużyć do wyliczeń przyszłych PKB per capita - por. Kusideł, Lewandowska-Gwarda [2012]).
} 
wróconego U nie oznacza malejących dysproporcji międzyregionalnych o czym świadczyły wyniki z tabeli 4.3.1.1 (zróżnicowanie wewnętrzne w tych krajach może odzwierciedlać inną część paraboli: rosnącą lub malejącą). Wśród krajów, które charakteryzuje dywergencja wewnętrzna (kraje o dodatnich wartościach tempa zmian nierówności w trzeciej kolumnie tabeli 4.3.1.1) znajdują się takie, dla których wyniki z tabeli 4.3.1.2 wskazują, że wewnątrzkrajowe nierówności mogą być przejściowe i po osiągnięciu maksimum powinny zacząć spadać. Dotyczy to w szczególności krajów zaliczanych do grupy 2 (w tym Polski) w tabeli 4.3.1.2 (w mniejszym stopniu, ze względu na nieistotne statystycznie parametry, dotyczy to krajów zaliczanych do grupy 3 ).

\subsection{Realizacja polityki spójności w Polsce}

Członkostwo Polski w Unii, które stało się faktem 1 maja 2004 r., było poprzedzone wieloletnimi przygotowaniami. Perspektywę członkostwa w Unii Polski i innych krajów Europy Środkowo-Wschodniej zarysował szczyt Rady Unii w Kopenhadze w roku 1993. Wyznaczył on równocześnie warunki tego procesu, znane jako „kryteria kopenhaskie”. W ramach przygotowań realizowano przedakcesyjne programy unijne: PHARE, SAPARD i ISPA. Programy te miały za zadanie pomóc krajom kandydującym w przygotowaniu do wypełnienia warunków związanych z członkostwem w UE. Najważniejszym z tych programów był PHARE (Poland and Hungary Assistance in Restructuring Economies). Początkowo, zgodnie z nazwą programu, był to program przeznaczony dla Polski i Węgier (o programie PHARE i jego historii pisze M. Klimowicz [2010, ss. 3439], skąd zaczerpnięto informacje na temat programów przedakcesyjnych). Pomoc $w$ ramach PHARE dotyczyła po pierwsze diagnozy obszarów, w stosunku do których będą zastosowane środki pomocy unijnej oraz ewentualne efekty ich zastosowania (ewaluacja ex ante). Drugim kierunkiem działań programu PHARE było bezpośrednie finansowanie inwestycji w określonych sektorach gospodarczych. Program ten w ramach środków na rozwój instytucjonalny pomógł przygotować odpowiednie instytucje do korzystania $\mathrm{z}$ funduszy ISPA i SAPARD. ISPA (Instrument for Structural Policies for Pre-Accession) został utworzony w 1999 r., a jego zadaniem było wsparcie mające na celu przygotowanie do członkostwa 10 krajów Europy Środkowo-Wschodniej (oprócz Polski były to: Bułgaria, Czechy, Estonia, Węgry Łotwa, Litwa, Rumunia, Słowacja, Słowenia) w obszarze spójności ekonomicznej i społecznej dotyczącej polityki ochrony środowiska i transportu. Do tej samej grupy krajów był kierowany, utworzony w 2000 r., SAPARD (Special Accession Programme for Agriculture and Rural Development). Zgodnie ze swoją nazwą, program wspierał rolnictwo i obszary wiejskie.

Po akcesji do Unii w 2004 r. Polska włączyła się w trzeci z kolei okres programowania pomocy z funduszy strukturalnych i realizacji polityki spójności: na 
lata 2000-2006. Był to okres, w którym znacząco uwidoczniły się zmiany w założeniach polityki regionalnej UE. Założenia te mocno uwypuklały element spójności wewnątrz UE, co miało wyraz w fakcie, że znaczącą większość środków skierowano na realizację celu pierwszego dotyczącego wspierania rozwoju i dostosowania strukturalnego regionów opóźnionych w rozwoju. W literaturze przedmiotu czasami zamiennie używa się terminów polityka regionalna, polityka strukturalna, czy polityka spójności. Polityka spójności finansowana jest przede wszystkim z funduszy strukturalnych (Europejskiego Funduszu Społecznego oraz Europejskiego Funduszu Rozwoju Regionalnego), w mniejszym stopniu z funduszu spójności. A zatem pomimo zbieżności nazw: polityki spójności i funduszu spójności, ten ostatni nie jest głównym źródła finansowania polityki o której mowa w tym rozdziale - są nim fundusze strukturalne - por. tabela 4.4.1.1. Główne różnice pomiędzy funduszem spójności, a funduszami strukturalnymi to:

- zasięg oddziaływania - fundusz spójności dotyczy programów o ogólnokrajowym charakterze (a nie regionalnym, jak w przypadku funduszy strukturalnych);

- kryterium przyznawania środków - które przyjęto na poziomie 90\% DNB (Dochodu Narodowego Brutto) per capita UE25 (a nie 75\% PKB per capita UE25, jak w przypadku funduszy strukturalnych);

- cele działania, które w przypadku funduszu spójności koncentrują się na dwóch obszarach: ochronie środowiska i infrastrukturze transportowej.

W bieżącym okresie programowania (2007-2013), wktórym Polska może uczestniczyć od samego początku, znalazła wyraz ponowna reforma polityki strukturalnej wynikająca m.in. z konsekwencji rozszerzenia Unii w 2004 r. o państwa o niższym potencjale gospodarczym. Cele zreformowanej polityki regionalnej ewoluują w kierunku konkurencyjności i wsparcia dla czynników podażowych, tj. innowacyjności, czy przedsiębiorczości. Znalazło to odbicie w nazwach celów polityki unijnej z: wsparcia regionów zapóźnionych w rozwoju (cel 1), odbudowy terenów silnie uzależnionych od upadających gałęzi gospodarki (cel 2) i modernizacji rynku pracy (cel 3) w latach 2000-2006 na: konwergencję (cel 1), konkurencyjność regionalną i zatrudnienie (cel 2) oraz europejską współpracę terytorialną (cel 3) w latach 2007-2013. Polska, której wszystkie regiony zakwalifikowano do realizacji celu „Konwergencja”, na który skierowano $80 \%$ wszystkich środków unijnej polityki spójności, jest jednocześnie największym beneficjentem tej polityki w okresie 2007-2013, o czym szerzej traktuje poniższy podrozdział.

\subsubsection{Transfery z UE do Polski na realizację polityki spójności}

Wydatki ponoszone ze środków publicznych na zadania objęte zakresem funduszy strukturalnych i funduszu spójności noszą miano wydatków strukturalnych. 
W polskim prawie finansowym zakres wydatków strukturalnych określony został po raz pierwszy w rozporządzeniu Ministra Finansów z dnia 21 grudnia 2004 r. w sprawie szczegółowej klasyfikacji wydatków strukturalnych (por. Malinowska-Misiąg i in. [2008, s.66]). Głównym kryterium zaliczania kosztów do wydatków strukturalnych jest nie tyle pochodzenie środków finansowych, co rodzaj zadania nimi objętego. Oznacza to, że wydatki strukturalne nie ograniczają się do tych finansowanych $\mathrm{z}$ UE, ale także są finansowane ze środków krajowych, co jest zgodne z zasadą dodatkowości. Zasada ta (dodatkowości) mówi o tym, że środki pieniężne przekazywane przez Komisję Europejską powinny być uzupełnieniem środków zgromadzonych i przeznaczonych na dany projekt przez władze państwowe, regionalne lub lokalne kraju członkowskiego (nie powinny zastępować finansowania krajowego). Zakres finansowania krajowego zmieniał się w zależności od okresu programowania oraz w szczególności od finansowanych zadań, lecz stanowił zdecydowaną mniejszość wartości projektów realizowanych w ramach celów polityki spójności.

Wg danych Ministerstwa Finansów o transferach z UE (przepływy rejestrowane w momencie wpływu na rachunek w NBP raportowane na stronach internetowych Ministerstwa Finansów: www.mf.gov.pl), do Polski od 1 maja 2004 r. do kwietnia $2011 \mathrm{r}$. wpłynęło w sumie $51835 \mathrm{mln}$ euro, z czego na realizację polityki spójności przeznaczono $30411 \mathrm{mln}$ euro (59\%). Pozostała kwota to głównie środki na realizację Wspólnej Polityki Rolnej $(33 \%)^{21}$. Polityka spójności finansowana była, zgodnie z danymi z tabeli 4.4.1.1, w 70\% z funduszy strukturalnych i w 24\% $\mathrm{z}$ funduszu spójności (pozostała część to środki z przedakcesyjnego funduszu ISPA, którego zobowiązania płatnicze przejął fundusz spójności).

Tabela 4.4.1.1. Transfery $z$ UE - przepływy rejestrowane na rachunku $w$ NBP $w$ mln euro

\begin{tabular}{|l|r|}
\hline Rodzaje transferów & Wielkość transferów narastająco \\
\hline I. Transfery z UE do Polski w tym: & 51835 \\
\hline 1. Polityka Spójności & 30411 \\
\hline Fundusz Spójności - perspektywa finansowa 2004-2006 & 2656 \\
\hline Fundusz Spójności - perspektywa finansowa 2007-2013 & 4666 \\
\hline ISPA & 1681 \\
\hline Fundusze Strukturalne & 21409 \\
\hline W ramach perspektywy finansowej 2007-2013 & 13256 \\
\hline 2.Wspólna Polityka Rolna & 17337 \\
\hline
\end{tabular}

Źródło: opracowanie własne na raportów MF dostępnych na http://www.mf.gov.pl

\footnotetext{
${ }^{21}$ Należy wyraźnie pokreślić, że w pracy niniejszej podjęto wątek ewaluacji jedynie funduszy przeznaczanych na realizację polityki spójności. Odrębną kwestię stanowi ewaluacja Wspólnej Polityki Rolnej, która nie stanowi przedmiotu rozważań w tej pracy, a której wiele badań poświęca A. Czyżewski (którego wykaz prac z tej dziedziny można znaleźć na stronach bibliografii publikacji pracowników Uniwersytetu Ekonomicznego w Poznaniu: www.bg.ae.poznan).
} 


\subsubsection{Alokacje wojewódzkie transferów $\mathrm{z}$ polityki spójności}

Finansowym instrumentem wspierania polityki regionalnej w Polsce w ramach poprzedniego okresu finansowania polityki spójności ${ }^{22}$ był Zintegrowany Program Operacyjny Rozwoju Regionalnego (ZPORR). W bieżącej perspektywie, której cele opisują Narodowe Strategiczne Ramy Odniesienia 2007-2013 (NSRO 2007-2013) są to głównie Regionalne Programy Operacyjne (RPO) ${ }^{23}$. Do rozdziału środków na RPO w bieżącej (2007-2013) perspektywie finansowej użyto identycznego, co w NPR 2004-2006, algorytmu 80/10/10, polegającego na tym, że wszystkie regiony uczestniczą w podziale $80 \%$ ogółu środków według liczby ludności, a tylko $20 \%$ środków rozdzielanych jest wg kryterium niskiego PKB na 1 mieszkańca i wysokiej stopy bezrobocia.

Tabela 4.4.2.1. Wartość bezpośredniej alokacji środków z NPR 2004-2006 (województwa uporządkowane wg dofinansowania per capita)

\begin{tabular}{|c|c|c|c|}
\hline Województwo & $\begin{array}{l}\text { Całkowita wartość do- } \\
\text { finansowania w mln zl }\end{array}$ & Udzial województwa & $\begin{array}{l}\text { Wartość dofinansowa- } \\
\text { nia w zl per capita }\end{array}$ \\
\hline podkarpackie & 3479 & $3,3 \%$ & 1656 \\
\hline małopolskie & 5497 & $5,2 \%$ & 1669 \\
\hline opolskie & 1865 & $1,8 \%$ & 1807 \\
\hline lubelskie & 4106 & $3,9 \%$ & 1901 \\
\hline świętokrzyskie & 2497 & $2,4 \%$ & 1964 \\
\hline podlaskie & 2465 & $2,3 \%$ & 2070 \\
\hline kujawsko-pomorskie & 4849 & $4,6 \%$ & 2344 \\
\hline lubuskie & 2386 & $2,3 \%$ & 2363 \\
\hline wielkopolskie & 8156 & $7,8 \%$ & 2396 \\
\hline warmińsko-mazurskie & 3709 & $3,5 \%$ & 2598 \\
\hline łódzkie & 6735 & $6,4 \%$ & 2646 \\
\hline pomorskie & 6021 & $5,7 \%$ & 2706 \\
\hline Śląskie & 13360 & $12,7 \%$ & 2877 \\
\hline dolnośląskie & 8483 & $8,1 \%$ & 2949 \\
\hline mazowieckie & 17360 & $16,5 \%$ & 3330 \\
\hline zachodniopomorskie & 5755 & $5,5 \%$ & 3399 \\
\hline Poziom krajowy & 8508 & $8,1 \%$ & \\
\hline RAZEM & 105200 & $100,0 \%$ & 2757 \\
\hline 5 najbogatszych & 53379 & $51 \%$ & 2907 \\
\hline 5 najbiedniejszych & 16256 & $15 \%$ & 1995 \\
\hline
\end{tabular}

Źródło: opracowanie własne na postawie Wielkość i struktura ... [2010, tabela A2, s. 57]

\footnotetext{
${ }^{22}$ Dokumentem określającym kierunki wsparcia unijnego w Polsce w okresie 2004-2006 był Narodowy Plan Rozwoju (NPR) 2004-2006.

${ }^{23} \mathrm{~W}$ bieżącym okresie programowania regionalne rozdysponowanie środków dotyczy nie tylko RPO, ale również programu operacyjnego Rozwój Polski Wschodniej (PO RPW) oraz 60\% środków z programu operacyjnego Kapitał Ludzki (reszta środków tego programu zarządzana jest na szczeblu krajowym). Choć największa kwota regionalnych alokacji przypada oczywiście na RPO.
} 
Algorytm przyznawania środków 80/10/10 kieruje je do najludniejszych regionów, do których należą województwa najbogatsze. Liczba ludności 5 najbogatszych województw stanowi ok. połowy populacji Polski i tyle mniej więcej środków $(50 \%)$ trafiło na te obszary w ramach wszystkich programów finansowanych z NPR 2004-2006. Natomiast liczba ludności 5 najbiedniejszych województw stanowi niecałe $22 \%$, tymczasem beneficjenci z tego obszaru pozyskali zaledwie $15 \%$ ogólnej puli środków na lata 2004-2006 - por. ostatnie dwa wiersze tabeli 4.4.2.1. Ponieważ faktyczne wykorzystanie środków przez województwa Polski Wschodniej było nawet mniejsze niż wynikałoby to z algorytmu 80/10/10 zatem ostatecznie, również w przeliczeniu per capita, pięć najuboższych województw otrzymało znacznie mniej niż średnia dla Polski.

Tabela 4.4.2.2. Planowy podzial środków $w$ ramach programów regionalnych $w$ NSRO 2007-2013 (województwa uporządkowane wg dofinansowania per capita)

\begin{tabular}{|c|c|c|c|c|c|c|}
\hline Program & $\begin{array}{c}\text { EFRR } \\
\text { w mln } €\end{array}$ & $\begin{array}{c}\text { PO KL } \\
\text { w mln } €\end{array}$ & $\begin{array}{c}\text { PO } \\
\text { RPW }^{24} \\
\text { w mln } €\end{array}$ & $\begin{array}{c}\text { EFRR+ } \\
\text { PO KL+ } \\
\text { PO } \\
\text { RPW } \\
\text { w mln } €\end{array}$ & $\begin{array}{c}\text { Struktu- } \\
\text { ra dofi- } \\
\text { nans. }\end{array}$ & $\begin{array}{c}\text { Wartość } \\
\text { dofi- } \\
\text { nans.w } \\
€ \\
\text { per capi- } \\
\text { ta }\end{array}$ \\
\hline mazowieckie & 1831 & 722 & & 2554 & $10,20 \%$ & 488 \\
\hline śląskie & 1713 & 588 & 143 & 2443 & $9,80 \%$ & 527 \\
\hline pomorskie & 885 & 299 & & 1184 & $4,70 \%$ & 529 \\
\hline opolskie & 427 & 139 & & 566 & $2,30 \%$ & 549 \\
\hline dolnośląskie & 1213 & 386 & & 1600 & $6,40 \%$ & 555 \\
\hline wielkopolskie & 1273 & 482 & 143 & 1898 & $7,60 \%$ & 557 \\
\hline lubuskie & 439 & 142 & & 582 & $2,30 \%$ & 576 \\
\hline małopolskie & 1290 & 470 & 143 & 1903 & $7,60 \%$ & 577 \\
\hline łódzkie & 1006 & 401 & 143 & 1550 & $6,20 \%$ & 610 \\
\hline kujawsko-pom. & 951 & 319 & & 1270 & $5,10 \%$ & 613 \\
\hline zachodniopom. & 835 & 244 & & 1079 & $4,30 \%$ & 639 \\
\hline podkarpackie & 1136 & 344 & 487 & 1968 & $7,90 \%$ & 937 \\
\hline lubelskie & 1156 & 408 & 509 & 2072 & $8,30 \%$ & 964 \\
\hline podlaskie & 636 & 207 & 387 & 1230 & $4,90 \%$ & 1034 \\
\hline świętokrzyskie & 726 & 253 & 375 & 1354 & $5,40 \%$ & 1066 \\
\hline warmińsko-maz. & 1037 & 249 & 447 & 1733 & $6,90 \%$ & 1212 \\
\hline RAZEM & 16556 & 5654 & 2776 & 24985 & $100 \%$ & 654 \\
\hline 5 najbogatszych & 6915 & 2478 & 285 & 9678 & $38,7 \%$ & 531 \\
\hline 5 najuboższych & 4691 & 1461 & 2206 & 8357 & $26,5 \%$ & 1043 \\
\hline
\end{tabular}

Źródło: opracowanie własne na podstawie Narodowe Strategiczne Ramy Odniesienia 2007-2013, tabela 12 oraz Davis [2008, s. 297]

Powyższe zestawienia wykorzystane zostaną (i skomentowane) w rozdziale 6.3 gdzie formułowana jest ocena wpływu realizacji polityki spójności w Polsce.

${ }^{24}$ Zawarto tutaj również rozdysponowanie środków wyrównawczych dla pozostałych regionów. 


\subsection{Podsumowanie}

Odpowiadając na pierwsze ze szczegółowych pytań zadanych (we wstępie) w związku z realizacją trzeciego głównego celu pracy należy stwierdzić, że na przestrzeni ostatnich kilkuset lat w skali świata dominowała dywergencja, która utrzymuje się do czasów bieżących. Dzisiejsze różnice w poziomie życia są zdecydowanie większe niż kiedyś: maksymalnie kilkuset procentowe różnice pomiędzy najbogatszymi i najbiedniejszymi gospodarkami w odległej historii są dzisiaj różnicami rzędu kilkudziesięciu tysięcy procent (w 2010 r. przeciętny dochód mieszkańca Kataru był 567 razy większy niż mieszkańca Konga). Oczywiście w tak heterogenicznej grupie, jaką tworzą kraje świata, nie ma mowy o konwergencji. Jeśli jednak weźmie się pod uwagę bardziej homogeniczne grupy krajów, to proces zbieżności ich gospodarek jest bardziej widoczny. Szczególną grupę tworzą kraje Unii Europejskiej, które oprócz wspólnoty terytorialnej, stworzenia jednolitego rynku, realizują wspólne polityki.

Wraz z akcesją do Unii w 2004 r., Polska stała się beneficjentem polityki spójności - polityki regionalnej ${ }^{25}$ Unii Europejskiej, dążącej do podwyższenia poziomu spójności gospodarczej, społecznej i terytorialnej (przestrzennej). W tym samym roku polityka regionalna Unii Europejskiej stanęła przed największym wyzwaniem od początku swego funkcjonowania, bowiem dążenie do spójności gospodarczej odbywa się w warunkach większego niż kiedykolwiek zróżnicowania. Przyjęcie 10 nowych krajów odwróciło rosnący od lat 80 . trend w nierównościach dochodowych w UE, lecz kosztem znacznego wzrostu ich poziomu. Dodatkowo ujawnił się dość typowy dla UE dysonans polegający na tym, że procesowi konwergencji zewnętrznej towarzyszy w wielu krajach dywergencja wewnętrzna (co pozwala na pozytywną odpowiedź na drugie z pytań szczegółowych celu trzeciego pracy).

Polityka spójności, której budżet na lata 2007-2013 wynosi 347 miliardów euro, stanowi, na szczeblu UE, największe źródło finansowania inwestycji we wzrost gospodarczy i zatrudnienie (por. Europejska polityka..., [2009, s. 1]). Początkowo, polityka ta nie była traktowana priorytetowo: w 1980 r. przeznaczano na nią zaledwie $11 \%$ całości budżetu UE. W końcu tej samej dekady, po wzrostach nierówności dochodowych pomiędzy krajami-członkami Wspólnoty udział środków na rozwój regionalny wyniósł $15 \%$ w 1988 r., następnie $30 \%$ w roku 1992, aż do 36\% całego budżetu Unii w bieżącym okresie programowania.

\footnotetext{
${ }^{25}$ Powiązanie polityki strukturalnej, regionalnej ze spójnością (która jest głównym celem regionalnej polityki UE) powoduje, że w literaturze przedmiotu czasami zamiennie używa się terminów polityka regionalna (polityka rozwoju regionalnego), polityka strukturalna, czy polityka spójności (polemikę na ten temat podejmuje Tkaczyński i in. [2008, s.69]).
} 
Polityka spójności stała się jedną z największych polityk wspólnotowych, a środki na jej realizację zostały pogrupowane według celów priorytetowych. Ponad $80 \%$ wszystkich wydatków w ramach funduszy strukturalnych wspiera działania w ramach pierwszego celu polityki spójności - konwergencji. W ramach tego celu Unia Europejska wspiera rozwój infrastruktury oraz potencjału gospodarczego i ludzkiego najuboższych regionów NUTS 2, do których zaliczają się wszystkie województwa Polski. Łączna suma dotacji unijnej na realizację polityki spójności w Polsce w latach 2007-2013 wynosi ponad 67 mld euro, co czyni Polskę jej największym beneficjentem. „,W rzeczy samej, z wielu powodów Polska wobecnej chwili może być postrzegana jako jedno $z$ najciekawszych ,laboratoriów” rozwoju regionalnego wUE i nie tylko. Po pierwsze od połowy lat 90. ubieglego stulecia, kiedy to środki przeznaczone na rozwój regionalny $w$ Polsce byty bardzo ograniczone, sytuacja uległa zmianie $i$ obecnie na ten cel dostępne sa znaczne fundusze. Środki finansowe pochodza głownie z funduszy strukturalnych dostęnych w ramach unijnej polityki spójności, a Polska jest ich największym beneficjentem w catej UE” (Ferry [2008, s. 173]).

Powstaje pytanie, czy środki przeznaczane na wyrównywanie poziomów rozwoju regionów - czyli konwergencję - są skuteczne. W wieku pracach badawczych poddaje się $\mathrm{w}$ wątpliwość skuteczność polityki spójności. Wątpliwości te opierają się głównie na dwóch faktach: 1) niezdolności wspieranych regionów do samodzielnego wzrostu po wstrzymaniu pomocy zewnętrznej i 2) obecności dowodów potwierdzających, że spójność międzyregionalna, która była normą do późnych lat 70. już nie występuje (Rodrigues, Fratesi [2004]). Odpowiedź na te pytania starano się sformułować w rozdziale 6, poprzedzając te analizy opisem metod pozwalających wnioskować o wpływie polityki spójności w rozdziale 5 . 


\section{ROZDZIAL 5}

\section{EWALUACJA POLITYKI SPÓJNOŚCI}

Trudno jednoznacznie zdefiniować ewaluację. W związku z multidyscyplinarnym charakterem tego zjawiska niektóre definicje związane są stricte z zainteresowaniami i metodami badawczymi wykorzystywanymi przez autorów owych definicji. Według jednych ewaluacja to ,zróżnicowany zestaw metod i dziatań zorientowany na krytyczna refleksję nad wartościa i jakościa interwencji publicznych - zarówno procesów ich wdrażania jak i ich efektów" (za: Olejniczak i in., red., [2008, s.19]). Według definicji M. Pattona, prezesa Amerykańskiego Towarzystwa Ewaluacyjnego i doświadczonego praktyka w tym temacie, ewaluację można określić, jako „proces systematycznego gromadzenia informacji na temat działania, właściwości i rezultatów programów, personelu oraz produktów, które sq wykorzystywane przez specjalistów do redukowania niepewności wokót programu i poprawienia jego efektywności, a także stuża podejmowaniu decyzji z uwagi na to, co owe programy, personel lub produkty robia oraz czego dotycza" (za: Ekiert [2004, s. 6-7]). Bank Światowy traktuje ewaluację jako: „użyteczne, wiarygodne i przejrzyste badanie, które opierając się na obiektywnych podstawach, ocenia wdrażanie i efekty polityk, programów, projektów. Tym samym ewaluacja przyczynia się do wzmacniania odpowiedzialności dziatań [Banku], oraz pomaga wyciagać wnioski i doskonalić przyszte interwencje"(za: Olejniczak i in., red., [2008, s. 21]. Obszerną definicję ewaluacji podaje Komitet Pomocy Rozwojowej Organizacji Współpracy Gospodarczej i Rozwoju: „Ewaluacja jest to systematyczna i obiektywna ocena trwajacego lub zakonczonego projektu, programu lub polityki - ich zaplanowania, wdrożenia i rezultatów. Celem ewaluacji jest określenie adekwatności i stopnia osiagnięcia celów, efektywności, skuteczności, wpływu i trwatości. Ewaluacja powinna dostarczać wiarygodnych i przydatnych informacji pozwalając na wykorzystanie zdobytych $w$ ten sposób wniosków w procesie podejmowania decyzji - zarówno przez odbiorców, jak i dawców interwencji. Ewaluacja dotyczy także procesu określenia wartości lub ważności działania, polityki lub programu. Jest systematyczna i możliwie jak najbardziej obiektywna ocena planowanej, trwajacej lub zakończonej interwencji. W niektórych przypadkach, w zakres ewaluacji wchodzi określenie odpowiednich standardów, ocena aktualnych lub oczekiwanych rezultatów oraz wyciagnięcie odpowiednich wniosków" (za: Mazur [2007, s. 29]). Powyższa definicja nawiązuje do kryteriów, procesu ewaluacji oraz jej celów i wyników (o których szerzej traktuje rozdział $5.3)$.

W niniejszej książce przyjęto definicję ewaluacji zgodną z Rozporządzeniem Rady Unii Europejskiej (z dn. 21.06.1999 r. wprowadzającym ogólne przepisy 
dotyczące funduszy strukturalnych). Według Rozporządzenia, ewaluacja to ocena wartości interwencji (w niniejszej książce dotyczących realizacji polityki spójności) z zastosowaniem określonych kryteriów tejże oceny, podejmowana w celu określenia efektywności interwencji, oszacowania w odniesieniu do celów, a także analizy wpływu na specyficzne problemy strukturalne.

\subsection{Metody ewaluacji polityki spójności}

Zgodnie z powyższą definicją ewaluacja to taka ocena interwencji, która powinna pozwolić na pomiar jej efektów odpowiadając na pytanie o zmiany nią wywołane. Taka definicja leży u podstaw tzw. ewaluacji wpływu, która jest przedmiotem rozważań $\mathrm{w}$ niniejsze książce ${ }^{1}$. Na ewaluację wpływu składają się zarówno ilościowe, jak i jakościowe metody, które mogą być stosowane komplementarnie lub substytucyjnie.

Metody jakościowe, koncentrują się na potencjalnych korzyściach jakie mogą być generowane przez programy, mechanizmach ich powstawania i, często, na pogłębionej analizie przypadków (case study) grup beneficjentów. Metody ilościowe pozwalają zmierzyć wpływ osiągnięty z powodu wdrożenia programu ${ }^{2}$. Oszacowanie efektu (wyrażanego wartościami wybranych wskaźników), jaki został uzyskany tylko i wyłącznie dzięki ewaluowanej polityce nazywany jest $\mathrm{w}$ literaturze przedmiotu efektem netto. W im większym stopniu realizacja projektu (programu, polityki) była uzależniona od interwencji, tym większy efekt netto. Efekt oddziaływania powinien być zatem mierzony jako różnica pomiędzy efektami z udziałem programu i bez niego. W praktyce, nie można obser-

\footnotetext{
${ }^{1}$ Chociaż ewaluacja wpływu (impact evalutation) może być oddzielona od innych metod ewaluacji takich jak M\&E (monitoring and evaluation), można komplementarnie traktować wnioski z obu podejść. Chociaż M\&E nie odpowiada na pytanie, czy indykatory wpływu są rezultatem wprowadzenia programu, ewaluacja wpływu często korzysta z M\&E do analizy i zrozumienia celów projektu, dróg jego oddziaływania, czy sformułowania miar efektu dla grupy docelowej (por. Khandker i in., [2010, s. 4]).

${ }^{2}$ Należy zauważyć jednocześnie, że samo dokonanie pomiaru oddziaływania interwencji, które stanowi sedno ewaluacji wpływu, nie stanowi ewaluacji w pełnym tego słowa znaczeniu. Chcąc realizować zadanie ewaluacji, jakim jest przynoszenie wiedzy w zakresie możliwych usprawnień realizowanych programów i działań, należy odpowiadać na pytania o przyczyny ich porażek i sukcesów. Badania typu impact evaluation mają w tym względzie ograniczone możliwości (por. http://www.mrr.gov.pl/aktualnosci/polityka_rozwoju/Documents/agenda_91112pl.pdf, pobrane 18.03.2013). Dlatego badania takie powinny być, jeśli to możliwe, uzupełnione o analizę jakościową pozwalającą na te pytania odpowiedzieć. W tego rodzaju badaniach, wpisujących się $\mathrm{w}$ ogólną ideę triangulacji (typologia triangulacji autorstwa Michaela Q. Pattona [1990, s. 464-465] wymienia triangulację: źródeł informacji, metodologiczną, analityczną i teoretyczną) autorka miała okazję wielokrotnie uczestniczyć (por. Drążkiewicz i in. [2007, 2009, 2010, 2011] - raporty dostępne na stronach Ministerstwa Rozwoju Regionalnego). Zastosowanie w tych badaniach triangulacji, poprzez zwielokrotnienie źródeł danych oraz zestawienie i porównanie ze sobą wyników z różnych metod (ilościowych i jakościowych) prowadziło do zwiększenia możliwości wnioskowania o oddziaływaniu ewaluowanych programów.
} 
wować obu tych stanów jednocześnie. Jeśli po realizacji programu obserwuje się wyższy poziom zadanych wskaźników, to przyrost tego zjawiska nie jest jedynie wynikiem działania programu, bowiem jakaś jego część jest z pewnością wygenerowana niezależnie. Rozróżnienie to można zobrazować poniższymi wykresami. Po lewej stronie znajduje się idea efektu brutto - różnicy pomiędzy wartością badanej zmiennej po programie i przed jego realizacją. Po prawej stronie zobrazowano efekt netto, który jest jedynie częścią efektu brutto, którą można przypisać realizacji projektu.

Rys. 5.1.1. Wizualizacja efektu brutto i netto interwencji
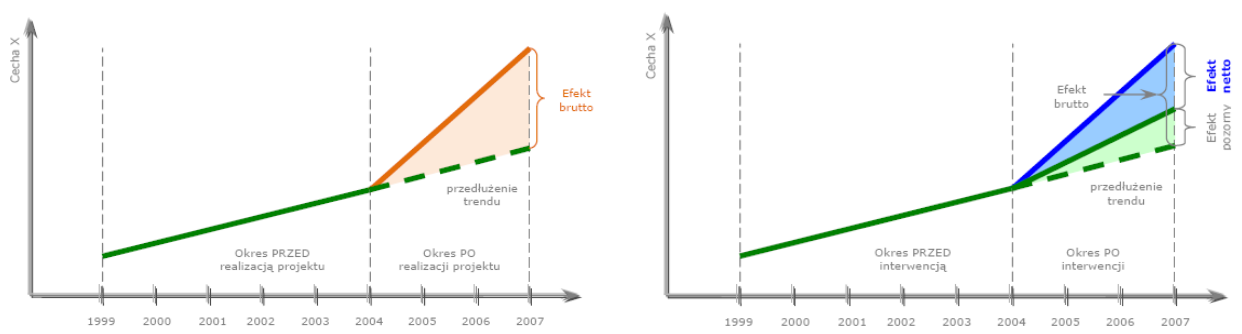

Źródło: Pylak i in. [2009, s. 27, 29]

Formalnie, do wyliczenia efektu brutto $(E B)$ służy następujący wzór:

$$
E B_{T}=\left(\hat{Y}_{T z f}-\hat{Y}_{T b f}\right)
$$

gdzie:

$\hat{Y}_{T_{z f}}$ - teoretyczna wartość w roku $T$ funkcji trendu badanego zjawiska oszacowanej dla danych z okresu po wprowadzeniu programu, $\hat{Y}_{\text {Tbf }}$ - teoretyczna wartość w roku $T$ funkcji trendu badanego zjawiska oszacowanej dla danych przed wprowadzeniem programu.

Pytaniem, które należy zadać przy próbie obliczenia efektu netto jest: co stałoby się gdyby program się nie pojawił? Aby zmierzyć rzeczywiste efekty działania programów należałoby od stanu faktycznego odjąć stan zjawiska, który zrealizowałby się, gdyby program się nie pojawił. Należy zatem porównać zmiany faktyczne ze zmianami kontrfaktycznymi (w hipotetycznej sytuacji pokazującej co by się stało gdyby program, czy polityka nie były wdrażane). Sposoby wyliczania zmian kontrfaktycznych są kluczowe z punktu widzenia ilościowych metod ewaluacji wpływu i dzielą je na metody eksperymentalne (randomizacyjne) i nieeksperymentalne. Te pierwsze polegają na tym, że zarówno grupa beneficjentów, jak i porównawcza (kontrolna) są dobierane losowo. Jeśli randomizacja jest dokonywana na odpowiednio dużej próbie, to jedyną różnicą pomiędzy beneficjentami i nie-beneficjentami jest fakt, że ci pierwsi korzystają z interwencji. Tego rodzaju podejście jest nazywane „złotym standardem” ewaluacji 
i jest jedynym, które pozwala pokazać związek przyczynowy pomiędzy interwencją i jej wynikami bez tzw. obciążenia selekcji próby ( selection bias ${ }^{3}$ ), które jest głównym problemem ilościowych ewaluacji wpływu. W praktyce eksperymentalny (losowy) dobór jest najczęściej niemożliwy do zastosowania z powodów praktycznych, metodologicznych, lecz także etycznych (por. Bamberger i White [2007], Scriven [2008], Deaton [2009]). Dlatego większość ilościowych badań ewaluacyjnych wykorzystuje nieeksperymentalne lub quasieksperymentalne metody doboru próby kontrolnej (wszystkie te metody próbują w różny sposób eliminować obciążenie selekcji próby).

Ze względu na różnorodność i różnokierunkowość wsparcia w ramach polityki spójności, trudno jest zsyntetyzować wyniki płynące z poszczególnych projektów czy programów operacyjnych tak, aby otrzymać wpływ całej polityki na procesy gospodarcze w kraju czy regionie. Dlatego do analiz tego typu używa się zazwyczaj ekonomicznych modeli symulacyjnych, które opisują działanie całych gospodarek. Na podstawie wyników z tego rodzaju modeli formułuje się scenariusze gospodarcze, w których podaje się wartości badanych zmiennych przy wykorzystaniu środków na ewaluowaną politykę oraz wartości w scenariuszu, który zakłada brak badanego dofinansowania - jest to scenariusz kontrfaktyczny ${ }^{4}$. Różnica wartości pomiędzy tymi scenariuszami jest wpływem polityki na badane zjawisko. Modele, które ten wpływ badają są dość skomplikowanymi konstrukcjami matematycznymi, o których szerzej traktuje poniższy podrozdział.

\subsubsection{Przegląd modeli wykorzystywanych w Europie do ewaluacji polityki spójności}

Wraz ze wzrostem zainteresowania ewaluacją polityki spójności wzrosła liczba stosowanych w tym celu narzędzi. Ponieważ proces i mechanizmy wpływu tej polityki mogą obejmować wszystkie aspekty gospodarki zatem, aby przeprowadzić takie badanie, potrzebne są ramy analityczne obejmujące jej całość. Ramy takie tworzą modele makroekonomiczne, które są ,praktycznie jedynym narzedziem, które może być użyte do formalnego potwierdzenia, czy polityka europejska osiagnęta zatożone cele" (por. Evaluating...[2003]). Przegląd modeli stosowanych przy ewaluacji funduszy można znaleźć w Review of Methodology... [2010], jak i w Evaluating... [2003]. Pomimo dużej różnorodności konstrukcji wskazywanych w powyższych opracowaniach można, w pewnym uogólnieniu,

\footnotetext{
${ }^{3}$ Obciążenie selekcji próby polega, w uproszczeniu, na ryzyku obciążenia pomiaru efektu interwencji z powodu selekcji do grupy beneficjentów obiektów (osób, przedsiębiorstw), których charakterystyki wpływają na efekt (np. uczestnictwo w szkoleniach osób o przeciętnie wyższym wykształceniu niż w grupie kontrolnej jest, obok szkolenia, jednym z powodów osiągania przez te osoby lepszych wyników po programie).

${ }^{4}$ Często używa się dla tych scenariuszy nazw: scenariusz bazowy i alternatywny.
} 
wskazać na dwie klasy modeli wykorzystywanych w ewaluacji polityki spójności:

1) modele intput-output oraz modele równowagi ogólnej klasy CGE (ang. Computational General Equilibrium) lub DSGE (Dynamic Stochastic General Equilibrium),

2) modele makroekonometryczne ${ }^{5}$.

Poniżej pokazano wybór stosowanych modeli w różnych krajach wraz z wynikającym z nich wpływem funduszy na PKB. Opis wybranych modeli znajduje się w dalszych podrozdziałach, gdzie również skomentowano niektóre wyniki z tabeli 5.1.1.

Tabela 5.1.1. Makroekonomiczne skutki (w pkt. proc.) wspierania rozwoju gospodarczego

\begin{tabular}{|c|c|c|c|c|}
\hline Kraj & Rodzaj analizy & Analizowane fundusze & Okres & $\begin{array}{l}\text { Wpływ } \\
\text { na PKB }\end{array}$ \\
\hline \multirow{2}{*}{ Grecja } & dynamiczny model input-output & $\begin{array}{l}\text { środki zagraniczne } \mathrm{w} \text { ra- } \\
\text { mach akcji strukturalnych }\end{array}$ & $2000-2006$ & 1,1 \\
\hline & $\begin{array}{l}\text { makroekonometryczny model } \\
\text { gospodarki HERMIN }\end{array}$ & całość akcji strukturalnych & 1994-1999 & 0,67 \\
\hline Estonia & $\begin{array}{l}\text { makroekonometryczny } \\
\text { gospodarki HERMIN }\end{array}$ & całość akcji strukturalnych & $2004-2010$ & 1,16 \\
\hline \multirow{3}{*}{ Hiszpania } & dynamiczny model input-output & $\begin{array}{l}\text { środki zagraniczne w ra- } \\
\text { mach akcji strukturalnych }\end{array}$ & $2000-2006$ & 1,29 \\
\hline & $\begin{array}{l}\text { ekonometryczny model produk- } \\
\text { tu i zatrudnienia }\end{array}$ & całość akcji strukturalnych & $1994-2000$ & 1,68 \\
\hline & $\begin{array}{l}\text { makroekonometryczny } \\
\text { gospodarki HERMIN }\end{array}$ & całość akcji strukturalnych & 1994-1999 & 1,07 \\
\hline \multirow{2}{*}{ Irlandia } & dynamiczny model input-output & $\begin{array}{l}\text { środki zagraniczne w ra- } \\
\text { mach akcji strukturalnych }\end{array}$ & $2000-2006$ & 1,05 \\
\hline & $\begin{array}{l}\text { makroekonometryczny model } \\
\text { gospodarki HERMIN }\end{array}$ & całość akcji strukturalnych & 1994-1999 & 1,44 \\
\hline $\begin{array}{l}\text { Irladnia } \\
\text { północna }\end{array}$ & $\begin{array}{l}\text { makroekonometryczny model } \\
\text { gospodarki HERMIN }\end{array}$ & całość akcji strukturalnych & 1994-1999 & 1,25 \\
\hline \multirow{2}{*}{$\begin{array}{l}\text { Niemcy } \\
\text { Wschodnie }\end{array}$} & dynamiczny model input-output & $\begin{array}{l}\text { środki zagraniczne w ra- } \\
\text { mach akcji strukturalnych }\end{array}$ & $2000-2006$ & 1,40 \\
\hline & $\begin{array}{l}\text { makroekonometryczny model } \\
\text { gospodarki HERMIN }\end{array}$ & całość akcji strukturalnych & 1994-1999 & 1,69 \\
\hline \multirow{2}{*}{ Portugalia } & Dynamiczny model input-output & $\begin{array}{l}\text { środki zagraniczne w ra- } \\
\text { mach akcji strukturalnych }\end{array}$ & $2000-2006$ & 1,52 \\
\hline & $\begin{array}{l}\text { makroekonometryczny } \\
\text { gospodarki HERMIN }\end{array}$ & całość akcji strukturalnych & 1994-1999 & 1,12 \\
\hline Słowenia & Model CGE & $\begin{array}{l}\text { środki zagraniczne w ra- } \\
\text { mach akcji strukturalnych }\end{array}$ & $2004-2006$ & 0,23 \\
\hline Węgry & Model makroekonometryczny & całość akcji strukturalnych & $2004-2006$ & 1,71 \\
\hline $\begin{array}{l}\text { Włochy } \\
\text { Południowe }\end{array}$ & dynamiczny model input-output & $\begin{array}{l}\text { środki zagraniczne w ra- } \\
\text { mach akcji strukturalnych }\end{array}$ & $2000-2006$ & 1,47 \\
\hline
\end{tabular}

Źródło: opracowanie własne na podstawie Kaczor [2005, ss. 50-51]

\footnotetext{
${ }^{5}$ Jeśli traktować ekonometrię jako naukę, która wykorzystuje narzędzia matematyczne, statystyczne i informatyczne do badania ilościowych związków zachodzących między zjawiskami ekonomicznymi, to każdy model można nazwać ekonometrycznym. Niemniej w literaturze przedmiotu dotyczącej metod ewaluacji, dokonuje się wyróżnienia modeli (makro) ekonometrycznych w celu podkreślenia, że wykorzystują one metody regresji (estymacji parametrów przy wykorzystaniu historycznych danych).
} 


\subsubsection{Historia, opis i zastosowania wybranych modeli}

Modele intput-output (które stosunkowo często pojawiały się w tabeli 5.1.1) wraz z keynesowskim równaniami równowagi są protoplastą modeli CGE (por. Olejniczak i in., red., [2008, s. 182]). Modele CGE zaś, popularne w latach 80. XX w., należą, wraz z DSGE, do klasy modeli równowagi ogólnej, które łączą metodyczne i poznawcze doświadczenia wielu szkół ekonomicznych odwzorowując sposób funkcjonowania gospodarki odwołujący się do mikroekonomicznych wzorców zachowań poszczególnych grup podmiotów. Odpowiadają one na krytykę Lucasa, który zarzucał ówczesnym (lata 70-80. XX w.) modelom makroekonometrycznym brak możliwości odwzorowania oczekiwań społecznych ${ }^{6}$.

Popularnym tego typu modelem jest używany w Komisji Europejskiej model QUEST III - (por. Ratto, Roeger, Veld [2008], Varga, Veld [2010]), który należy do klasy modeli DSGE estymowanych w oparciu o metody bayesowskie ${ }^{7}$. QUEST jest od wielu lat rozwijany przez Komisję Europejską (jego wcześniejsze wersje oznaczone były numerami I i II), a równolegle do niego stosowany jest ECOMOD (rozwijany przez EcoMod i Wolny Uniwersytet w Brukseli), który powstał w celu ewaluacji wpływu funduszy wszystkich krajów dla okresu programowania $2007-2013^{8}$.

Popularnym w Europie modelem, reprezentującym drugą, z wymienionych w paragrafie 5.1.1 grupę modeli (makroekonometrycznych) służących do ewalua-

\footnotetext{
${ }^{6}$ Jest to jedna z wielu konkluzji wynikających ze sławnej krytyki Roberta Lucasa z 1976 r., którą zawarł w pracy pt. Econometric Policy Evaluation: a Critique.

${ }^{7}$ W Polsce teorią i zastosowaniami metod bayesowskich zajmuje się J. Osiewalski, którego wykaz prac $\mathrm{z}$ tego zakresu można znaleźć na stronie domowej autora (http://www.cyfronet.krakow.pl/ eeosiewa/pubpol.htm).

${ }^{8}$ Modele tego typu wykorzystywane są nie tylko do ewaluacji funduszy unijnych wykonywanych przez instytucje za nie odpowiedzialne, lecz również używane są przez różne instytucje: banki centralne, uczelnie, instytuty badawcze. Na przykład Centrum Studiów Gospodarczych Katolickiego Uniwersytetu Leuven wykorzystuje model GEM3 (Global Economy Model) typu CGE. Międzynarodowy Fundusz Walutowy wykorzystuje również model GEM oraz GFM (Global Fiscal Model), które reprezentują klasę modeli DSGE dużej skali. W Finlandii używa się modelu VERM i REGFIN, należących do klasy CGE i które wykorzystywane są do analiz regionalnych (fińskie modele wykorzystywane są głównie przez tamtejszy Rząd do analizy i weryfikacji polityki budżetowej). W Holandii używa się z kolei regionalnego modelu CGE o nazwie RAEM, służącego do ewaluacji polityk regionalnych Należy jeszcze wspomnieć o modelu E3ME (EnergyEnviroment-Economy Model of Europe), który jest rozwijany przez Cambridge Econometrics i używany jest w CEDEFOP (Europeane Centre for the Development of Vocational Training). $\mathrm{W}$ ramach realizowanego przez wiele lat projektu dotyczącego prognoz podaży pracy i popytu na pracę dla większości krajów europejskich, zaangażowanych było kilkudziesięciu ekspertów z poszczególnych krajów (m.in. autorka niniejszej pracy jako polski contributing expert do spraw modelowania popytu na pracę).
} 
cji polityki spójności jest (co wynika z tabeli 5.1.1) model HERMIN ${ }^{9}$. Jego protoplastą był model HERMES (Harmonised Econometric Research for Modelling Economic Systems), który powstał $\mathrm{z}$ inicjatywy Unii Europejskiej w $1982 r .{ }^{10}$ i jest typowym modelem ekonometrycznym opisującym zależności ekonomiczne w gospodarce (ze specjalnym wyróżnieniem bloku rynku pracy). Model HERMIN został pierwotnie zbudowany przez dr. Johna Bradleya z Instytutu Badań Społeczno-Ekonomicznych w Dublinie (The Economic and Social Research Institute - ESRI) do modelowania średniookresowych efektów w gospodarce Irlandii ${ }^{11}$. W modelu HERMIN mechanizm zagregowanego popytu modelowany jest w sposób keynesowski, natomiast podaż kształtowana jest przez ceny i konkurencyjność kosztową (a zatem w sposób neoklasyczny - por. Olejniczak, red., [2008, s. 183]). W latach 1992-1996 model HERMIN zastosowano w Grecji, Irlandii, Portugalii i Hiszpanii, później w ramach programu ACE-PHARE w latach 1997-1999 w krajach Europy Środkowo-Wschodniej (Czechy, Rumunia, Słowenia). Następnie, w latach 1999-2002, w ramach prac nad Narodowymi Planami Rozwoju, model wykorzystano do analiz makroekonomicznych w Estonii, Łotwie i w Polsce, a w roku 2003 rozpoczęto prace nad modelem dla Węgier. W Polsce dokonano adaptacji modelu HERMIN do potrzeb modelowania polskiej gospodarki w roku 2002, w ramach przeprowadzonej oceny Narodowego Planu Rozwoju na lata 2004-2006. Jak piszą główni autorzy tego badania Bradley i Zaleski [2002, s. 2]: „inspiracja dla początkowej pracy nad obecnym modelem dotyczacym Polski zrodziła się z wcześniejszych modeli opracowanych dla krajów dążacych do osiagnięcia spójności z UE, poniewaz strukturalne zmiany obecnie zachodzace w Polsce nosza oczywiste podobieństwa do tych, które obecnie wystepuja w krajach i regionach UE przechodzacych proces osiagania spójności”.

Kolejnym etapem rozwoju modelu HERMIN była jego regionalizacja i w rezultacie, w latach 2000-2003, model został zaadoptowany we Wschodnich Landach Niemiec, Irlandii Północnej oraz w Mezzogiorno we Włoszech (por. Perło [2008, s. 2]). Regionalny model HERMIN gospodarki polskiej został po raz pierwszy przygotowany w 2004 r. przez Wrocławską Agencję Rozwoju Regionalnego (por. Zaleski i in. [październik 2004]). W 2005 r. zaczęły po-

\footnotetext{
${ }^{9} \mathrm{~W}$ tej grupie modeli znajduje się również REMI-NET (Regional Economic Models), którego nie omówiono tutaj bardziej szczegółowo. Jest on regionalnym modelem ekonometrycznym, którego oryginalna wersja została opracowana na Uniwersytecie w Massachusetts w 1977, zaś holenderska (bardziej znana) wersja została opracowana w Holandii przez firmy REMI Inc i Ecorys.

${ }^{10}$ Por. D' Alcantara, Italianer [1982].

${ }^{11}$ Rozwinięcia modelu HERMES dokonane przez Johna Bradleya i in. dotyczyły gospodarki irlandzkiej w latach 80-90. XX w. i polegały głównie na większej orientacji podażowej (ale również traktowaniu sektora usług jako częściowo konkurencyjnego dla światowej gospodarki, rozbudowaniu bloku rynku pracy, zmianach w równaniach migracji i podaży pracy, czy włączeniu sektora energetycznego w rynek gospodarstw domowych).
} 
wstawać modele regionalne jako część większego projektu polegającego na zbudowaniu modeli regionalnych dla wszystkich województw w kraju. W projekcie tym oparto się na analizie scenariuszowych rozwiązań autorskiego modelu ekonometrycznego, stanowiącego modyfikację i rozwinięcie pierwotnej krajowej (por. Zaleski i in. [2004]) i regionalnej (por. Zaleski i in. [2005]) wersji modelu HERMIN. W modelach regionalnych wszystkie równania zostały ponownie oszacowane (skalibrowane), lecz na bardzo krótkiej próbie obejmującej lata 1998-2003. Ten niewielki zakres próby był m.in. powodem ostrożności jego autorów odnośnie do wyników, które kazali traktować jako jedynie szacunkowe i poglądowe. W czerwcu 2011 r. zespół pod kierownictwem prof. Zaleskiego opublikował ostatni raport dotyczący wpływu funduszy unijnych na gospodarki poszczególnych regionów przy użyciu modeli regionalnych HERMIN (por. Zaleski i in. [czerwiec 2011]), a od 2012 badanie to wykonuje dla MRR inny, niż Wrocławska Agencja Rozwoju Regionalnego, wykonawca.

Obecnie model HERMIN jest stosowany przez Komisję Europejską w ramach system CSHM - Cohesion System of HERMIN Models (por. A Cross-Country Impact...[2009] $\left.{ }^{12}\right)$.

\subsubsection{Wybór modelu do ewaluacji polityki spójności}

Stosunkowo najbardziej popularnym modelem wykorzystywanym do ewaluacji polityki spójności w Europie jest model HERMIN. Jego popularność jest po części spowodowana tym, że dostęp do kodów tego modelu jest otwarty (do niedawna wszystkie kody modelu krajowego i regionalnych dostępne były na stronie www.hermin.pl), co sprawia, że może być on powszechnie wykorzystywany. $\mathrm{Z}$ drugiej strony HERMIN jest stosunkowo często krytykowany. Zarzuca mu się, że jest to model, który powstał ponad 20 lat temu i od tego czasu uległ tylko nieznacznym modyfikacjom, opiera się na starych teoriach, nie uwzględniając bardziej współczesnego dorobku ekonomii ${ }^{13}$. Jest zorientowany na popytową stronę gospodarki i $\mathrm{z}$ tego względu ma tendencję do przeszacowywania wpływu polityk (por. Ederveen [2002], Capellen i in. [2002]), choć autorzy polskiej wersji modelu (Bradley, Zaleski [2004]) twierdzą z kolei, że analiza wrażliwości wskazuje na dość duży realizm wyników. Z tym ostatnim stwierdzeniem nie zgadzają się jednakże krytycy wskazujący, że szacunki modelu są nieprawidłowe, bo nie starają się oceniać wpływu samych polityk, a o-

\footnotetext{
${ }^{12}$ Zob. również Gáková i in. [2007].

${ }^{13}$ Choć fakt, że model nie podlegał istotnym zmianom przez ostatnie lata daje mu pewną przewagę nad innymi - porównywalność. Nawet jeżeli modele HERMIN przeszacowują wpływ polityk (co jest często podkreślanym zarzutem), to można przypuszczać, że podobnym obciążeniem charakteryzuje się większość stosowanych modeli HERMIN. Oczywiście powstaje pytanie, czy porównywalność jest wystarczającym argumentem, aby nie poprawiać „starych” konstrukcji, wobec nowych teorii i podejść w modelowaniu procesów ekonomicznych.
} 
siągnięte wyniki zależą od hipotez przyjętych przy ich konstruowaniu ${ }^{14}$. Model wykazuje stosunkowo małe powiązanie ze stroną podażową gospodarki oraz brak sprzężeń zwrotnych pomiędzy kluczowymi zmiennymi. Parametry modeli HERMIN są często kalibrowane (zamiast estymowane), co jego autorzy tłumaczą m.in. problemem z dostępnością odpowiednio długich szeregów danych statystycznych. Dlatego też modele te stosują stosunkowo niewielką dezagregację sektorową $^{15}$. Pewnym problemem ze stosowaniem HERMIN w Komisji Europejskiej jest fakt, że różnice w charakterystykach i funkcjonowaniu gospodarek powodują, że rozwinięcie jednego, wspólnego modelu makroekonomicznego dla EU (z jedną grupą parametrów dla wszystkich krajów UE) jest raczej zbyt ambitne (por. Review of Methodology... [2010]). Jednakże prace Gaskowej i in. [2007], [2009] oraz prowadzone w ramach Cohesion System of HERMIN Models pokazują, że takie próby są podejmowane.

Jednym z poważniejszych, teoretycznych, zarzutów kierowanych pod adresem modelu HERMIN jest jego nieodporność na krytykę Lucasa, która dotyczy strukturalnej niezmienniczości parametrów modeli i jej znaczenia dla analizy polityki gospodarczej. Lucas [1976] zakwestionował zasadność wykorzystywania modeli ekonometrycznych do eksperymentów symulacyjnych w dziedzinie polityki gospodarczej, stwierdzając, że struktura modelu może się zmienić pod wpływem oczekiwań związanych z realizacją określonej polityki. W szczególności chodzi tu o wpływ takich zmiennych, które mogą być traktowane jako instrumenty polityki tj. stopy procentowe, stopy podatków, poziom ceł itp ${ }^{16}$. Odpowiedzią na krytykę Lucasa miały być modele równowagi ogólnej, które dobrze się spełniają w analizie efektów (szoków) wywołanych zmianami $\mathrm{w}$ prowadzonych politykach i wpływających na różnego rodzaju rynki produktu lub rynek pracy. Zastosowania te, bazują m.in. na teorii równowagi rynkowej, której podstawy były dyskutowane przy okazji ekonomicznej Nagro-

\footnotetext{
${ }^{14}$ Przykładowo ewaluacje są zależne od przyjętych elastyczności efektów zewnętrznych. Zwiększenie tego czynnika spowoduje wzrost znaczenia programów strukturalnych. Dokładne wartości elastyczności nie są znane, dlatego podczas rozważania efektów polityk spójności powinno brać się pod uwagę szeroki ich zakres, co jednocześnie stwarza przestrzeń dla arbitralności przyjmowanych przez różnych autorów wartości.

${ }^{15}$ Zapowiadane próby rozszerzenia polskiej implementacji modelu z 4 do 10 sektorów, jak dotąd, nie powiodły się.

${ }^{16}$ Należy jednakże podkreślić, że realizacji polityki spójności nie można ściśle powiązać z pewną skokową zmianą jakiegokolwiek z analizowanych wskaźników ekonomicznych. Plany budżetowe poszczególnych programów operacyjnych są znane z dużym wyprzedzeniem (przed ich realizacją), więc jeśli ta informacja ma wpływ na zachowania się podmiotów na rynku, to jest to wpływ, który można uwzględnić w modelu, o którym mowa (czyli takim, który dokonuje ewaluacji przy znajomości budżetów). Oczywiście gospodarka zmienia się pod wpływem funduszy, lecz jest to proces raczej ciągły i powolny, więc nawet jeśli model, który ocenia tę politykę, ma pod jej wpływem niedoszacowne/przeszacowane parametry, to nie powinny to być błędy kardynalne. Dodatkowo, jeśli ewaluacja wpływu funduszy unijnych dotyczy przyszłych okresów (tzw. ewaluacja ex ante), to model będzie miał za zadanie głównie prognozować ten wpływ.
} 
dy Nobla z 2011 r. (nagroda za empiryczne badania dotyczące skutków polityk gospodarczych). Badania laureatów pokazały, że zwolennicy elastyczności i efektywności rynku, twierdzący, że w długim okresie rynek dostosowuje do siebie wielkość popytu i podaży (za pomocą mechanizmu cenowego) mogą się mylić. „Wygląda na to, że niewidzialna ręka rynku jest często rzeczywiście niewidzialna, zwtaszcza na rynku pracy, ponieważ $w$ wielu przypadkach po prostu nie istnieje” a „paradygmat doskonatej konkurencji na kompletnym rynku plynnie przeprowadzanych transakcji ekonomicznych, sformalizowany pod koniec XIX w. przez francuskiego ekonomistę Leona Walrasa, odchodzi powoli do lamusa" (za: Nowak, [2011, s. 135-136]).

Z kolei inne założenie modeli równowagi ogólnej, mających stanowić przeciwwagę dla typowych modeli ekonometrycznych - uzyskiwanie optimum przy istniejących ograniczeniach, wypływające $\mathrm{z}$ teorii racjonalnych oczekiwań, zakłada że agenci posiadają odpowiednią wiedzę i informację, aby takie oczekiwania formułować, z czym nie wszyscy badacze się zgadzają (por. Grauwe [2008], Tyszka i in. [2004]). Obrońcy klasycznych metod ekonometrycznych podkreślają również, że fakt, że w modelach równowagi ogólnej bierze się pod uwagę decyzje podejmowane na szczeblu mikroekonomicznym (gospodarstw domowych i firm) nie jest cechą jedynie pozytywną, bowiem gospodarka w skali makro ma swoje prawa odmienne od praw mikroekonomicznych (czego trawestacją jest powiedzenie, że las - w ujęciu ekonomii - nie jest sumą drzew).

Ostatecznie, pomimo większej odporności na krytykę Lucasa modeli równowagi ogólnej, trudno byłoby je wskazać jako generalnie lepsze od innych narzędzie służące ewaluacji polityki spójności ${ }^{17}$. Stosunkowo kompromisowym wyjściem jest stosowanie jednocześnie wielu narzędzi, z których wyniki mogą być traktowane jako maksymalne i minimalne wartości wpływu lub uśredniane. Takie podejście stosuje od lat polskie Ministerstwo Rozwoju Regionalnego, o czym szerzej traktuje poniższy podrozdział.

\subsubsection{Przegląd makromodeli stosowanych w ewaluacji polityki spójności w Polsce}

Jak już wspomniano, Rada Unii Europejskiej zobowiązała wszystkie państwa członkowskie do przeprowadzenia ewaluacji pomocy finansowej z funduszy strukturalnych UE. Dotyczy to w szczególności polityki spójności na którą przeznaczane są największe środki. W Polsce podmiotem zlecającym badania ewaluacyjne jest Krajowa Jednostka Oceny (KJO), której rolę pełni

\footnotetext{
${ }^{17}$ Ciekawe porównanie wyników ewaluacji polityki spójności za pomocą trzech różnych modeli: HERMIN, QUEST i ECOMOD przedstawione zostało przez J. Bradleya (pierwotnego autora HERMIN) i Untiedta [2007] w pracy o znamiennym tytule Do economic models tell us anything useful about Cohesion Policy impacts?
} 
Departament Koordynacji Polityki Strukturalnej umiejscowiony w Ministerstwie Rozwoju Regionalnego (obsługą organizacyjną prac KJO zajmuje się Wydział Ewaluacji). Odpowiada on za realizację procesu ewaluacji Narodowego Planu Rozwoju i Narodowych Strategicznych Ram Odniesienia oraz wypracowanie standardów i koordynację działań w zakresie ewaluacji prowadzonych w ramach poszczególnych programów operacyjnych. W sumie KJO zleciło kilkanaście tego rodzaju badań (niektóre mające charakter cykliczny), które wymieniono w tabeli 5.1.2.

Tabela 5.1.2. Tytuły najważniejszych i największych badań mających na celu ocenę wpływu polityki spójności w Polsce

\begin{tabular}{|c|c|c|c|}
\hline $\mathrm{Nr}$ & Tytul badania & $\begin{array}{l}\text { Rok } \\
\text { bad. }\end{array}$ & $\begin{array}{l}\text { Rodzaj } \\
\text { modelu }\end{array}$ \\
\hline 1 & $\begin{array}{l}\text { Ocena makroekonomicznego wpływu realizacji Narodowego Planu Rozwoju } \\
\text { na lata 2004-2006 oraz Narodowych Strategicznych Ram Odniesienia na lata } \\
2007-2013 \text { przy użyciu modelu HERMIN dla polskiej gospodarki }\end{array}$ & 2007 & Hermin \\
\hline 2 & $\begin{array}{l}\text { Ocena wpływu Narodowych Strategicznych Ram Odniesienia i Programów } \\
\text { Operacyjnych na lata 2007-2013 na polską gospodarkę przy pomocy modelu } \\
\text { makroekonomicznego HERMIN }\end{array}$ & 2006 & Hermin \\
\hline 3 & $\begin{array}{l}\text { Ocena wpływu Narodowych Strategicznych Ram Odniesienia i wybranych } \\
\text { Programów Operacyjnych na lata 2007-2013 na gospodarki polskich woje- } \\
\text { wództw przy pomocy modeli regionalnych HERMIN }\end{array}$ & 2006 & Hermin \\
\hline 4 & $\begin{array}{l}\text { Ocena szacunkowa Narodowych Strategicznych Ram Odniesienia na lata } \\
2007-2013^{19}\end{array}$ & 2006 & Specj. \\
\hline 5 & $\begin{array}{l}\text { Prognozy oddziaływania makroekonomicznego dokumentów programowych } \\
\text { na lata 2007-2013 na gospodarkę kraju i gospodarki regionalne wykonane } \\
\text { przy pomocy modelu równowagi ogólnej }\end{array}$ & 2006 & MaMoR \\
\hline 6 & $\begin{array}{l}\text { Badanie wpływu Narodowego Planu Rozwoju 2004-2006 i Narodowych } \\
\text { Strategicznych Ram Odniesienia 2007-2013 na wybrane wskaźniki dokumen- } \\
\text { tów strategicznych (za pomocą modelu MaMoR2) }\end{array}$ & 2008 & MaMoR \\
\hline 7 & $\begin{array}{l}\text { Wpływ realizacji inwestycji finansowanych z funduszy unijnych na kształto- } \\
\text { wanie się głównych wskaźników dokumentów strategicznych - Narodowego } \\
\text { Planu Rozwoju i Narodowej Strategii Spójności oraz innych wybranych } \\
\text { wskaźników makroekonomicznych na poziomie krajowym i wojewódzkim } \\
\text { (http://www.ewaluacja.gov.pl/Wyniki/Documents/npr_010.pdf). }\end{array}$ & 2008 & Hermin \\
\hline 8 & $\begin{array}{l}\text { Wpływ funduszy unijnych na gospodarkę Polski w latach 2004-2020 (za po- } \\
\text { mocą modelu EUImpactMod) }\end{array}$ & 2008 & EuImpact \\
\hline
\end{tabular}

${ }^{18}$ Jak wspominano wyżej ewaluację polityki spójności dla wszystkich krajów (również Polski) przeprowadza również cyklicznie Komisja Europejska, przy pomocy modelu HERMIN (w ramach Cohesion System of HERMIN Models), a także modelu QUEST III (por. Varga, Veld [2010]), którego najbardziej ogólnym wynikiem jest, że zmiana PKB jest proporcjonalna do wysokości otrzymanych funduszy -por. Dach [red.], 2011, s. 151.

${ }^{19} \mathrm{O}$ ile raporty 1, 2, 3 dotyczą wpływu polityki spójności na wskaźniki makroekonomiczne, to raport 4 ma na celu optymalizację podziału środków budżetowych w ramach programów operacyjnych na lata 2007-2013 oraz poprawę jakości tego dokumentu (por. Smuga [2006, s. 6]). W dokumencie tym wyraźnie jest mowa o podstawowych kryteriach ewaluacyjnych: trafności NSRO w stosunku do zidentyfikowanych potrzeb, skuteczności NSRO - jako prawdopodobienstwa osiągnięcia celów programu oraz użyteczności - oszacowanie spodziewanego oddziaływania w stosunku do szerszych - społecznych, środowiskowych i gospodarczych potrzeb. Należy również zwrócić uwagę, że część badań (nr 2, 3, 4, 5, 13) dotyczy tylko jednej z perspektyw finansowych (albo 2004-2006, albo 2007-2013). 


\begin{tabular}{|c|c|c|c|}
\hline 9 & $\begin{array}{l}\text { Badanie wpływu realizacji inwestycji finansowanych z funduszy unijnych na } \\
\text { kształtowanie się głównych wskaźników dokumentów strategicznych - Naro- } \\
\text { dowego Planu Rozwoju 2004-2006 i Narodowej Strategii Spójności 2007- } \\
2013 \text { oraz innych wybranych wskaźników makroekonomicznym }\end{array}$ & 2008 & EuImpact \\
\hline 10 & $\begin{array}{l}\text { Ocena zbieżności rozwoju społeczno-gospodarczego Polski z Unią Europej- } \\
\text { ską }\end{array}$ & 2007 & \\
\hline 11 & $\begin{array}{l}\text { Wpływ realizacji polityki spójności na kształtowanie się głównych wskaźni- } \\
\text { ków dokumentów strategicznych NPR 2004-2006 i NSS 2007-2013 }\end{array}$ & 2009 & MaMoR \\
\hline 12 & $\begin{array}{l}\text { Wpływ realizacji polityki spójności na kształtowanie się głównych wskaźni- } \\
\text { ków dokumentów strategicznych - Narodowego Planu Rozwoju 2004-2006 } \\
\text { i Narodowej Strategii Spójności } 2007-2013 \text { oraz innych wybranych wskaźni- } \\
\text { ków makroekonomicznych na poziomie krajowym }\end{array}$ & 2009 & EuImpact \\
\hline 13 & $\begin{array}{l}\text { Ocena systemu realizacji polityki spójności w Polsce w ramach perspektywy } \\
\text { 2004-2006 }\end{array}$ & 2010 & \\
\hline
\end{tabular}

Źródło: na podstawie „Bazy danych ewaluacyjnych” prowadzonej przez MRR

$\mathrm{Z}$ tabeli 5.1.2 wynika, że oceny wpływu polityki spójności w Polsce, dokonuje się za pomocą głównie trzech modeli: EuImpactMod, MaMoR oraz HERMIN, które reprezentują różne podejścia do modelowania gospodarki. Opis tych modeli można znaleźć w pracy Olejniczaka i in., red., [2008, rozdział 2.5, s. 189 i nast.]. Na uwagę zasługuje fakt, że zastosowanie różnych konstrukcji modelowych, będąc realizacją postulatu triangulacji metod (por. przypis $\mathrm{nr} 2$ ), pozwala na stosunkowo obiektywną ocenę wpływu polityki spójności.

\subsection{Rola czynników demograficznych $w$ analizie wpływu polityki spójności}

Głównym wskaźnikiem będącym przedmiotem oceny wpływu polityki spójności jest zazwyczaj PKB per capita. Domyślnie przyjmuje się, że oddziaływanie ewaluowanej polityki dotyczy licznika tego wskaźnika, czyli PKB. Tymczasem, co nie jest podkreślane w źródłach, polityka spójności może oddziaływać również na mianownik, czyli na liczbę ludności.

Eksperci zauważają, że ocena sytuacji demograficznej - zwykle bardzo trudna ze względu na występowanie wielu niezsynchronizowanych zmian trendów staje się w wypadku kraju takiego jak współczesna Polska, doświadczającego masowych migracji zagranicznych, zadaniem karkołomnym (por. Raport Polska 2030 [2009, s. 78]). Oprócz wpływu migracji na możliwości oceny przyszłych struktur demograficznych, bieżącym problemem z tego wynikającym jest fakt, że nieobecność dużej części populacji Polski może wpływać na jakość wskaźników demograficznych (osoby faktycznie nieobecne są nadal ujmowane w statystykach).

Różne źródła - różnie oceniają skalę i konsekwencje decyzji migracyjnych Polaków. Począwszy od umiarkowanych, w których stwierdza się, że „,migracje zarobkowe to fenomen społeczny na stałe obecny w świadomości Polaków. Jak wskazuja dane, w catym okresie transformacji na stałe pracowało poza Polska 
około miliona Polaków. Ostatnio obserwowana fala migracji - choć niewatpliwie przyciaga uwage mediów i pojawia się często $w$ debacie publicznej - stanowi bardziej kontynuacje tradycji, niż istotne novum $w$ wyborach życiowych Polaków” (za: Kaczmarczyk, Tyrowicz [2010]), aż po alarmujące, jak ,okres poakcesyjny przynióst spektakularne i niespotykane na gruncie europejskim doświadczenie masowego odpływu za granicę (zarówno jeśli chodzi o skalę zjawiska, jak i o jego dynamike)" (za: Raport Polska 2030, [2009, s. 78]). W cytowanym raporcie zauważono jednakże, że ,,ze większość dostępnych danych wskazuje na silna dynamikę migracji poakcesyjnych, ale również na ich $w$ dużej mierze czasowy charakter (...). W okresie transformacji systemowej dominowaty wyjazdy krótkie, często o sezonowym badź cyrkulacyjnym charakterze. Po $1 \mathrm{ma}$ ja 2004 r. pojawila się tendencja do wydlużania pobytu za granica, ale wciaż nie ma dowodów wskazujacych na masowe przekształcanie się migracji czasowych w osiedleńcze." (op.cit., s. 79) ${ }^{20}$.

Na ocenę skali wpływu polityki spójności mierzonej za pomocą wskaźników przeliczanych na liczbę ludności (takich jak PKB per capita) oddziałują również czynniki demograficzne - w tym decyzje migracyjne Polaków. Jeśli bowiem osoby nie przebywające $\mathrm{w}$ kraju są $\mathrm{w}$ dalszym ciągu ujmowane $\mathrm{w}$ statystyce mieszkańców, to zmniejsza to wartość PKB per capita zarówno poprzez zmniejszenie licznika tego wskaźnika (bowiem osoby te nie biorą de facto udziału w produkcji), jak i zwiększenie mianownika (bowiem wytworzona produkcja jest przeliczana na większą, niż faktycznie przebywająca w Polsce, liczbę osób). Jeśli na decyzje migracyjne wpłynęla akcesja do Unii, to poprzez fakt, że moment ten zbiegł się z momentem rozpoczęcia realizacji polityki spójności, można mówić o niebezpośrednim, jednak istniejącym, negatywnym powiązaniu tej polityki i PKB per capita.

Osobną kwestię stanowią prognozy demograficzne, które dla Polski nie są optymistyczne. Zmiany w strukturze wieku ludności i wynikający z nich proces starzenia się ludności dotyczy większości krajów świata. Wszelkie prognozy ludnościowe (zarówno na poziomie światowym/międzynarodowym opracowane przez ONZ i Eurostat, czy na poziomie lokalnym opracowane przez urzędy statystyczne poszczególnych krajów) wskazują na systematyczny wzrost udziału osób starszych oraz najstarszych w populacji (por. Kotowska, red., [2009, s. 73]). Prognozowany proces starzenia się ludności zbiega się w Polsce ze znacznym spadkiem ogólnej liczby ludności - przy czym prognozowane tempo spadku ludności w wieku produkcyjnym jest znacznie szybsze niż ogółu ludności.

\footnotetext{
${ }^{20}$ Ocena faktycznej skali migracji w Polsce nie jest prosta, bowiem wraz z rosnącymi możliwościami emigracji Polaków po akcesji do Unii, zmniejszyła się jednocześnie możliwość kontroli i śledzenia tego procesu, ze względu na fakt czasowej emigracji, a co za tym idzie braku śladu w statystykach rejestracji na pobyt stały (który monitoruje GUS).
} 
Przewidywane spadki liczby ludności w Polsce mogą mieć również konsekwencje dla wskaźników makroekonomicznych, które są przeliczane na liczbę mieszkańców ogółem lub na liczbę pracujących (zależną przecież od liczby osób w wieku produkcyjnym). Należy podkreślić, że w wymiarze ,statystycznym" konsekwencje te nie muszą być negatywne, szczególnie jeśli do przeliczeń użyje się nie całkowitej liczby mieszkańców lecz liczby mieszkańców w wieku produkcyjnym. Im większe tempo spadku mianownika ułamka takiego jak PKB na mieszkańca lub WDB na pracującego, tym wyższe tempo wzrostu całego wskaźnika, co może ułatwiać wnioskowanie o konwergencji zewnętrznej (rozumianej jako doganianie przez Polskę średniej dla UE). Będzie to jeszcze łatwiejsze jeśli średnią tę wyznaczać będą kraje UE 15 (a nie UE 25 lub UE 27), bowiem proces starzenia się społeczeństwa nie jest równomiernie rozłożony $\mathrm{w}$ krajach UE - przebiega gwałtowniej na wschodzie niż zachodzie Europy ${ }^{21}$.

\subsection{Kryteria ewaluacyjne}

W planowaniu ewaluacji - na co wskazywały definicje ewaluacji przytoczone na początku tego rozdziału - bardzo ważne jest podjęcie decyzji dotyczącej sposobu dokonania oceny. Chodzi tu o dobranie odpowiednich kryteriów ewaluacji stosowanych do określonego rodzaju badania. Jak wspomniano na początku tego rozdziału Komitet Pomocy Rozwojowej Organizacji Współpracy Gospodarczej i Rozwoju w swojej definicji ewaluacji zaproponował konkretne kryteria ewaluacji projektów i programów finansowanych ze środków Unii Europejskiej. Obecnie stosowane są one również w większości programów i projektów finansowanych przez organizacje takie jak ONZ czy Bank Światowy. Również Komisja Europejska zaleca przeprowadzanie oceny wpływu projektów funduszy unijnych wg następujących kryteriów ewaluacyjnych ${ }^{22}$ :

- trafność lub adekwatność (relevance) - pozwala ocenić, do jakiego stopnia cele programów są odpowiednie w stosunku do potrzeb i priorytetów obszarów objętych interwencją. W jakim stopniu cele polityki spójnóści odpowiadają potrzebom danego sektora czy regionu?

- użyteczność (utility) - pozwala ocenić, do jakiego stopnia oddziaływanie programów odpowiada potrzebom grupy docelowej. Czy realizacja polityki spójności przyczyni się do zaspokojenia potrzeb lub rozwiązania problemów regionów?

\footnotetext{
${ }^{21} \mathrm{O}$ wpływie prognoz demograficznych na bieżące i prognozowane wartości wskaźników rynku pracy można przeczytać w Kusideł, Modranka [2011].

${ }_{22}$ Na podstawie Ewaluacja programów...[1997, s. 17].
} 
- skuteczność (effectiveness) - pozwala ocenić, do jakiego stopnia oddziaływanie programów przyczyniło się do osiągnięcia ich celów szczegółowych i ogólnych.

- efektywność (efficiency) - pozwala ocenić poziom ekonomiczności programów, na przykład poprzez stosunek poniesionych nakładów do uzyskanych rezultatów. Badanie efektywności powinno pozwolić na stwierdzenie jak oszczędnie poszczególne nakłady zostały przekształcone w wyniki i rezultaty.

- trwałość (sustainability) - pozwala ocenić, w jakim zakresie można oczekiwać, że pozytywne zmiany będą trwać po zakończeniu programu.

Powyższe kryteria stosuje się zazwyczaj w odniesieniu do konkretnych projektów. W niniejszej pracy podjęto próbę oceny całej polityki spójności według tego schematu. W związku z tym należało określić zależności pomiędzy powyższymi kryteriami, a potrzebami beneficjentów, celami programów, nakładami, działaniami i wynikami. Zależności te, w przypadku dowolnej interwencji, pokazuje rys. 5.3.1, zaś w rozdziale 6 starano się zweryfikować działania polityki spójności w kontekście poszczególnych kryteriów.

Rys. 5.3.1. Zależności pomiędzy kryteriami ewaluacyjnymi a potrzebami, celami, nakładami i oddziaływaniem programów

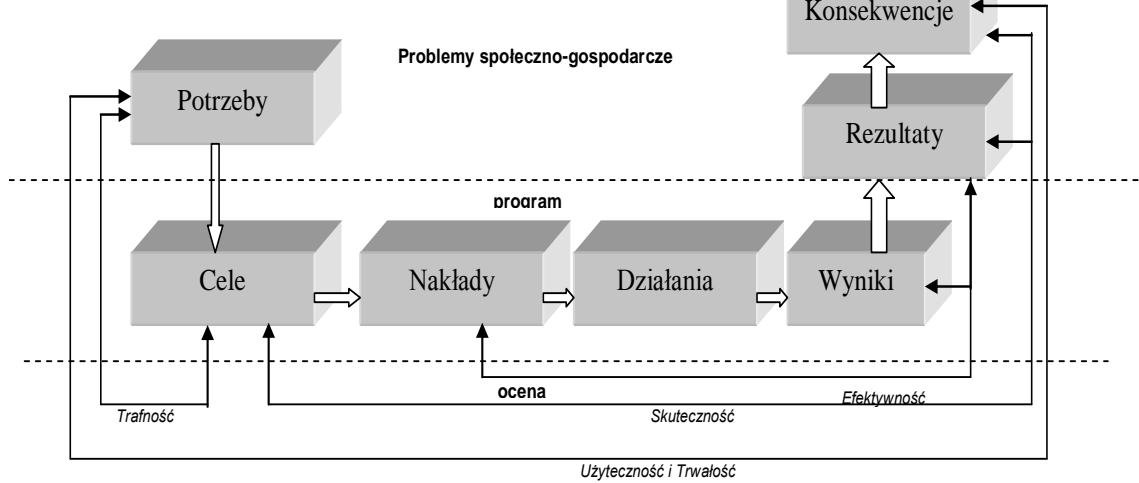

Źródło: Ewaluacja programów ...[1997, rys. 2.2, s. 18]

W kontekście ewaluacji polityki spójności zasadniczym wyzwaniem jest właściwe określenie potrzeb, celów i wyników/rezultatów/konsekwencji jej oddziaływania. Wszystkie te kryteria zdefiniowano wg pierwszego celu polityki spójności (którego nazwa w okresie programowania 2000-2006 brzmiała: „Wsparcie regionów zapóźnionych”, zaś w okresie 2007-2013: „Konwergencja”), na którego realizację przeznacza się największe środki (ponad 80\% w okresie programowani 2007-2013) i którego ewaluacja jest celem tej części książki (w któ- 
rej starano się odpowiedzieć na pytanie zawartej w jej tytule: o związki konwergencji gospodarczej z osiąganiem celów polityki spójności).

Ogólnie sformułowany cel (pierwszy) polityki spójności: konwergencja, wymagał większej operacjonalizacji. Poniżej przyjęto, że jest to konwergencja regionalnych PKB per capita (czyli konwergencja gospodarcza). Przy tak sformułowanym celu potrzeby regionów można zdefiniować podobnie do Komisji Europejskiej - poprzez kryterium PKB per capita. Takie kryterium - PKB per capita poniżej 75\% średniej unijnej - stosuje Komisja Europejska do kwalifikacji regionów NUTS 2 do realizacji głównego celu polityki spójności.

Zgodnie z rys. 5.3.1. kryterium skuteczności wymaga sformułowania rezultatów, które określono jako wzrost regionalnych PKB per capita, który można przypisać realizacji w nich polityki spójności. Kryterium użyteczności wymaga sformułowania długofalowych rezultatów (konsekwencji) oddziaływania programów. W przypadku realizacji polityki spójności w ramach celu 1 jest nim osiąganie konwergencji PKB per capita (jest to oczywiście zawężenie skali oddziaływania do obszaru gospodarki, ale tylko tego obszaru dotyczy niniejsza praca).

Poniżej sformułowano schemat przyjętej logiki oddziaływania celu 1 polityki spójności w kontekście kryteriów ewaluacyjnych, który stworzono na wzór ogólnej logiki oddziaływania programów zawartej w przewodniku do ewaluacji autorstwa Dyrekcji Generalnej XIX Komisji Europejskiej. 
Rys. 5.3.2. Powiązanie nakładów, oddziaływania i celów polityki spójności w kontekście osiągania konwergencji wewnętrznej

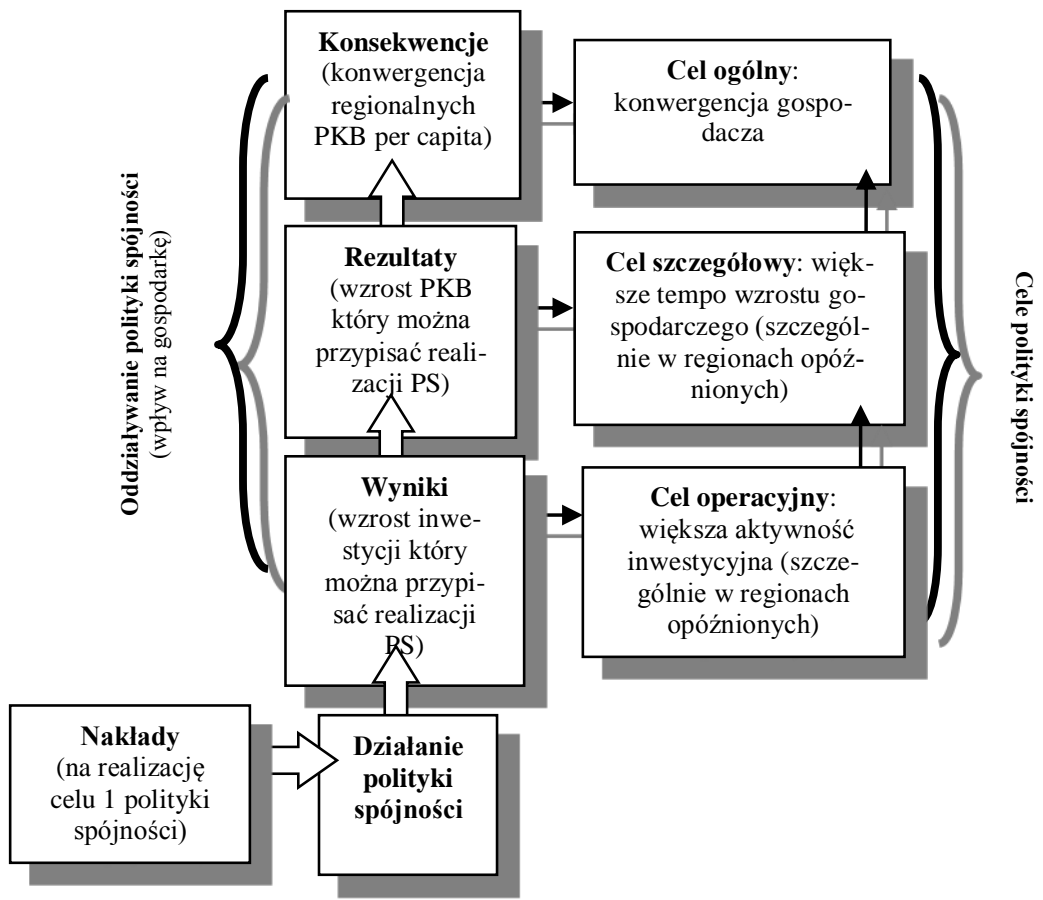

Źródło: opracowanie własne na podstawie Ewaluacja programów ... [1997, rys. 2.1, s. 17]

\subsection{Podsumowanie}

Zawartość niniejszego rozdziału służyła odpowiedzi na trzecie z kolei pytanie szczegółowe sformułowane $\mathrm{w}$ związku $\mathrm{z}$ realizacją celu pracy związanego $\mathrm{z}$ oceną wpływu realizacji polityki spójności na osiąganie konwergencji - pytanie o metody ewaluacji tej polityki.

W ewaluacji wpływu polityki spójności stosuje się metody ilościowe, które pozwalają oszacować efekt (wyrażony wartościami wybranych wskaźników), jaki został uzyskany dzięki realizacji tej polityki. W im większym stopniu realizacja projektów była uzależniona od interwencji - tym większy efekt netto. W teorii, efekt ten powinien być mierzony jako różnica pomiędzy efektami z udziałem programu i bez niego. W praktyce, nie można obserwować obu tych stanów jednocześnie, dlatego znaczenia nabierają metody ustalenia hipotetycznej sytuacji pokazującej co stałoby się, gdyby programy nie były wdrażane (tzw. scenariusz kontrfaktyczny, alternatywny).

W przypadku ewaluacji tak dużego programu jak polityka spójności trudno mówić o metodzie, która w jakikolwiek sposób koncentruje się na poszczegól- 
nych beneficjentach tego programu. Zakres oddziaływania polityki spójności jest tak szeroki, że do pomiaru jej efektów potrzebne są ramy analityczne całej gospodarki. Dlatego do analiz tego typu używa się zazwyczaj dużych, dość skomplikowanych modeli ekonomicznych, odzwierciedlających funkcjonowanie całych gospodarek. Na ich podstawie buduje się scenariusze rozwojowe, których porównanie pokazuje wpływ polityki spójności na różnorakie wskaźniki gospodarcze, w szczególności na PKB per capita.

W rozdziale tym pokazano jakie typy modeli stosowane są w Polsce i Europie do ewaluacji polityki spójności (por. p. 5.1). Generalnie trudno jest wskazać jedno, najlepsze narzędzie do ewaluacji wpływu polityki spójności, a przekonanie autorów co do przewagi jednego rozwiązania nad drugim jest często subiektywne, a czasami bywa negatywnie zweryfikowane przez czas i nowe teorie. Sam sposób uwzględnienia funduszy unijnych w modelach ekonomicznych i zakładane ich oddziaływanie na gospodarkę znacznie różnicuje pomiędzy sobą te konstrukcje i stanowi jedno ze źródeł rozbieżności wyników pochodzących z różnych modeli. Modele te - będąc autorskimi konstrukcjami odzwierciedlają zarówno teorie ekonomiczne, jak i doświadczenia, wiedzę i przekonanie samych autorów co do przebiegu procesów gospodarczych. Konsekwencją tego faktu jest sposób inkorporowania do modelu funduszy unijnych, co powoduje, że brak jest w tym temacie jednego wzorca postępowania - stąd duża różnorodność stosowanych w Polsce i Europie modeli.

Wyniki wszystkich modeli pokazują, że wpływ dodatkowych funduszy jest generalnie pozytywny (przyczynia się do wzrostów PKB per capita krajów je wykorzystujących). Polska nie jest pod tym względem wyjątkiem - realizacja polityki spójności pobudza w niej wzrost gospodarczy. Odziaływanie to jest jednakże zróżnicowane regionalnie, co pokazują badania $\mathrm{z}$ następnego rozdziału, $\mathrm{w}$ których starano się odpowiedzieć na pytania o oddziaływanie polityki spójności w kontekście sformułowanych w rozdziale 5.3. kryteriów ewaluacyjnych. 


\section{ROZDZIAL 6 \\ WPLYW POLITYKI SPÓJNOŚCI NA GOSPODARKI WOJEWÓDZTW I ICH KONWERGENCJĘ}

\subsection{Zmiany we wskaźnikach monitorujących politykę spójności w okresie po akcesji do Unii - efekt brutto}

Jak stwierdzono na początku rozdziału $5.1 \mathrm{w}$ ewaluacji funduszy unijnych (czy ogólnie polityk) oddziela się efekt netto od efektu brutto interwencji. Efekt brutto definiowany jest jako całkowita zmiana $w$ cechach opisujących funkcjonowanie danego obszaru wokresie po realizacji projektu (programu) w porównaniu $\mathrm{z}$ okresem przed jego realizacją.

Jedną z metod określenia efektu brutto wpływu funduszy jest metoda polegająca na ekstrapolacji historycznych trendów ${ }^{1}$. Wyliczenie różnicy pomiędzy obecnym stanem wskaźników a ich hipotetycznymi wartościami wynikającymi z ekstrapolacji trendów rozwojowych pozwala na wstępną ocenę zmian, jakie nastąpiły po realizacji programu.

Dla skwantyfikowanych celów polityki spójności, w celu obliczenia efektu brutto należy zbadać zmianę we wskaźnikach ekonomicznych, która nastąpiła w okresie po akcesji do Unii. W pracy Kusideł i Modranki [2011] autorki pokazały, że dynamika wskaźników monitorowanych w NSRO jest w okresie po akcesji do Unii zdecydowanie wyższa niż ich dynamika w analogicznym okresie poprzedzającym. Efekt brutto dla takich wskaźników jak udział zatrudnionych w 3 sektorach, wydajność pracy, wskaźniki zatrudnienia jest dodatni i wysoki. Nie oznacza to jednakże, że zmiana ta została wywołana jedynie przez politykę spójności.

Poniżej podano sposób wyliczenia efektu brutto w stosunku do badanego w tym rozdziale wskaźnika: PKB per capita w pps w stosunku do średniej UE 27. Na wykresie 6.1.1 pokazano wartości faktyczne oraz teoretyczne tego wskaźnika wynikające z ekstrapolacji funkcji trendu przed akcesją (trend 1997-2003) oraz po akcesji (trend 2004-2010) - por. wzór (5.1.1). Różnica pomiędzy tymi wartościami wynosi 10 punktów procentowych i oznacza, że bez realizacji polityki spójności w Polsce PKB per capita (EU27=100) byłby niższy o maksymalnie $10 \mathrm{pp}$.

\footnotetext{
${ }^{1}$ Mogą to być trendy pochodzące $\mathrm{z}$ jednorównaniowych modeli takich jak poniżej lub $\mathrm{z}$ bardziej skomplikowanych konstrukcji, jak np. modele VAR lub VECM. Tego rodzaju modele zostały zastosowane przez autorkę do oceny wpływu funduszy unijnych na zatrudnienie w pracy Drążkiewicz i in. [2007, s. 17].
} 
Wykres 6.1.1. Wizualizacja efektu brutto dla PKB per capita w pps (EU27=100)

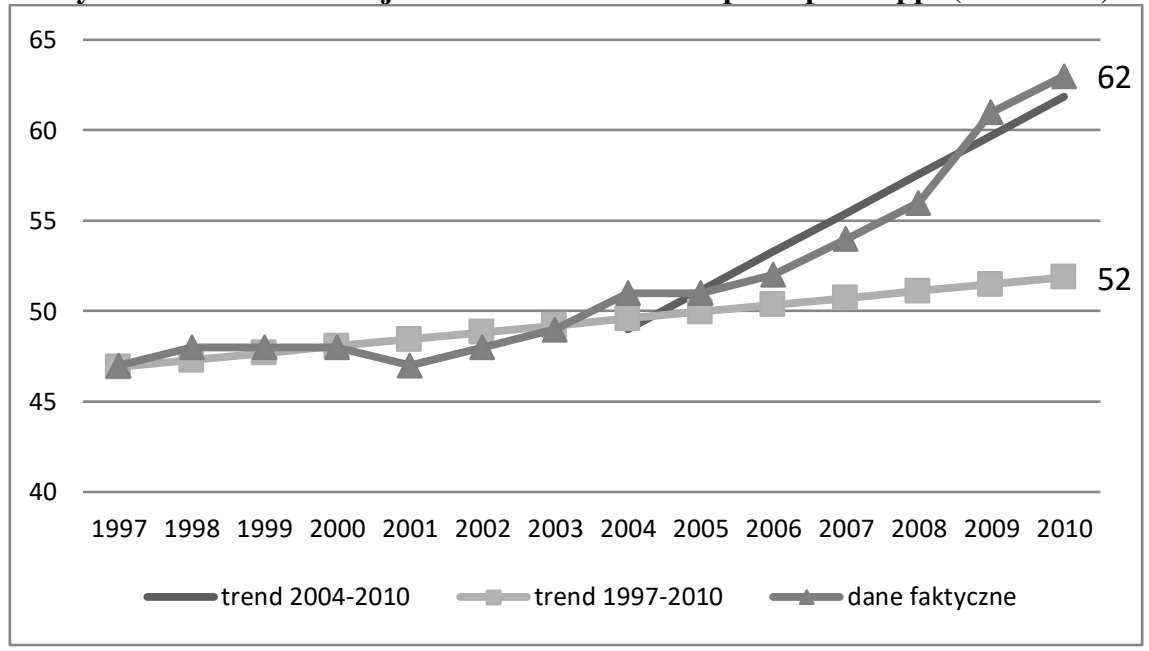

Źródło: opracowanie i obliczenia własne na podstawie danych z Eurostatu

Oczywiście tak obliczonego (i wysokiego) efektu nie można zrównywać z wynikiem realizacji polityki spójności. Dynamika wzrostu PKB per capita byłaby prawdopodobnie większa niż to wynika z ekstrapolacji trendu dla lat 19972003, nawet bez akcesji do Unii. Aby przekonać się jaka część z widocznej na powyższym wykresie 10-cio punktowej różnicy w PKB jest wynikiem realizacji polityki spójności należy obliczyć efekt, który może być przypisany tylko i wyłącznie pomocy publicznej, co uczyniono w poniższym podrozdziale.

\subsection{Wpływ polityki spójności na wskaźniki gospodarcze wg makromodeli gospodarki stosowanych w Polsce do ewaluacji funduszy}

Aby zmierzyć rzeczywiste efekty działania programu należy od stanu faktycznego odjąć stan zjawiska, który zrealizowałby się, gdyby program nie był wdrażany. W literaturze przedmiotu ten drugi stan określa się mianem stanu kontrfaktycznego. W praktyce nie można jednocześnie obserwować stanu faktycznego (z programem) i kontrfaktycznego (bez programu). Dlatego stan kontrfaktyczny ustalany jest specjalnymi metodami, do których należą m.in. symulacje $\mathrm{z}$ modeli makroekonomicznych ${ }^{2}$.

\footnotetext{
${ }^{2}$ Metod ustalania stanu kontrfaktycznego jest bardzo dużo: dopasowanie (matching), różnicowanie (differencing, difference-in-differences, double-difference), analiza danych panelowych, metoda zmiennych instrumentalnych, regresje typu discontinuity i pipeline. Stosunkowo dużą popularnością cieszy się ostatnio Propensity Score Matching (PSM) opracowana w pierwszej połowie
} 
W niniejszym rozdziale przywołano wyniki trzech modeli (zamawianych przez Ministerstwo Rozwoju Regionalnego odpowiedzialne za ewaluację polityki spójności w Polsce), których cykliczne wyniki pozwalają na odpowiedź na pytanie, jaki jest wpływ realizacji polityki spójności na kształtowanie się głównych wskaźników Narodowego Planu Rozwoju 2004-2006 i Narodowej Strategii Spójności 2007-2013 na poziomie krajowym i regionalnym. W wyniku prac trzech ośrodków badawczych, powstają raporty nt. wpływu funduszy unijnych m.in. na sytuację społeczno-ekonomiczną Polski ${ }^{3}$.

W przypadku większości wskaźników monitorowanych przez NSRO, zaobserwować można, że zmiany po akcesji do Unii były silniejsze niż w analogicznym okresie poprzedzającym - por. Kusidel, Modranka [2011]. Aby stwierdzić, jaką część tych pozytywnych zmian, można przypisać realizacji polityki spójności, należy oddzielić efekty wpływu funduszy od innych efektów gospodarczych. Temu służą przywoływane tutaj modele ekonomiczne, w których dokonuje się symulacji wartości wskaźników „bez funduszy” odpowiadających na pytanie: jaki byłby poziom wskaźników, gdyby fundusze na realizację polityki spójności do Polski nie napływały? Różnice pomiędzy wartością wskaźników „bez funduszy” i ,z funduszami”' (w przypadku ewaluacji ex post te ostatnie są faktycznymi wartości zmiennych) stanowią wielkość wpływu funduszy na gospodarkę. Jak już wspomniano, do oszacowania tego wpływu posłużono się wynikami trzech makromodeli używanych przez Krajową Jednostkę Oceny przy MRR do ewaluacji polityki spójności noszących nazwy: MaMoR (model CGE autorstwa konsorcjum Prevision-IBnGR), EuImpactMod (model DSGE autorstwa Instytutu Badań Strukturalnych) i Hermin (model makroekonometryczny autorstwa Wrocławskiej Agencji Rozwoju Regionalnego) - por. p. 5.1.2.

Na wykresach 6.2.1a - 6.2.1f zaprezentowano wpływ polityki spójności na wybrane wskaźniki gospodarcze mierzony za pomocą tych 3 modeli. Tendencje

lat osiemdziesiątych XX wieku przez D. Rubina i P. Rosenbauma. Od końca lat dziewięćdziesiątych (a w Polsce od roku 2005) można zauważyć wzrost jej popularności i częstości wykorzystania do oceny efektu interwencji publicznych (zastosowano ją np. w badaniach Drążkiewicza i in. [2010, 2011], w których uczestniczyła autorka). Metodom tym nie poświęcono wiele miejsca w tej pracy, bowiem do oceny polityki spójności wykorzystuje się najczęściej modele makroekonomiczne opisane w rozdziale 5.1.1, 5.1.2.

${ }^{3}$ Por. Wplyw realizacji polityki spójności na kształtowanie się głównych wskaźników dokumentów strategicznych NPR 2004-2006 i NSS 2007-2013, MRR, IBnGR, Prevision, Gdańsk, Warszawa 2011; Wplyw realizacji polityki spójności na ksztaltowanie się głównych wskaźników dokumentów strategicznych - Narodowego Planu Rozwoju 2004-2006 i Narodowej Strategii Spójności 20072013 oraz innych wybranych wskaźników na poziomie krajowym i regionalnym, Instytut Badań Strukturalnych, Warszawa 2011; Wpływ realizacji polityki spójności na ksztaltowanie się glównych wskaźników dokumentów strategicznych - Narodowego Planu Rozwoju 2004-2006 i Narodowej Strategii Spójności 2007-2013 oraz innych wybranych wskaźników makroekonomicznych na poziomie krajowym za pomoca modelu Hermin, Wrocławska Agencja Rozwoju Regionalnego, Wrocław 2011. 
widoczne na tych wykresach pokazują, że wpływ funduszy na wybrane wskaźniki makroekonomiczne jest generalnie pozytywny, co pokazuje również tabela 6.2.1.

Tabela 6.2.1. Średnie tempa zmian $(\mathrm{w} \%)^{4}$ dla lat 2004-2010 wskaźników dla faktycznych danych (druga kolumna) oraz dla symulacji ,bez funduszy"

\begin{tabular}{|c|c|c|c|c|}
\hline $\begin{array}{c}\text { Wskaźniki celu strategicznego } \\
\text { NSRO }\end{array}$ & $\begin{array}{c}\text { Syne } \\
\text { faktyczne }\end{array}$ & MaMoR & EuImpactM & Hermin \\
\hline $\begin{array}{c}\text { PKB per capita w pps } \\
\text { (UE27=100) }\end{array}$ & 3,9 & 3,2 & 3,0 & 3,1 \\
\hline $\begin{array}{c}\text { Udział zatrudnionych w sektorze } \\
\text { II }\end{array}$ & 1,2 & 1,1 & 1,1 & 0,9 \\
\hline $\begin{array}{c}\text { Udział zatrudnionych w sektorze } \\
\text { III }\end{array}$ & 1,0 & 1,1 & 1,1 & 2,1 \\
\hline $\begin{array}{c}\text { Wskaźnik zatrudnienia osób } \\
\text { w wieku 15-64 lata }\end{array}$ & 2,6 & 2,4 & 1,8 & 2,4 \\
\hline $\begin{array}{c}\text { kobiety } \\
\text { mężczyźni }\end{array}$ & 2,6 & 2,5 & 1,8 & 2,3 \\
\hline
\end{tabular}

Źródło: obliczenia własne na podstawie danych GUS oraz wyników modeli wymienionych w przypisie $\mathrm{nr} 3$

Wykres 6.2.1a. Wpływ funduszy na PKB per capita w pps $(\mathrm{UE27}=100)$

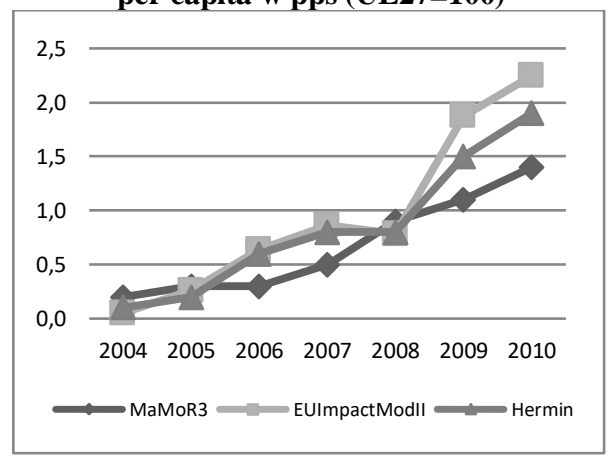

Wykres 6.2.1b. Wpływ funduszy na wskaźnik zatrudnienia $w$ pkt proc.

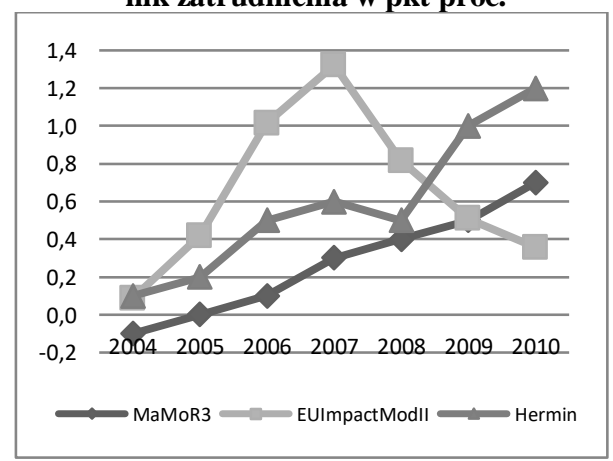

\footnotetext{
${ }^{4}$ Wyliczone na podstawie wykładniczych modeli trendu.

${ }^{5}$ Nie uwzględniono rolnictwa, bowiem na ten sektor gospodarczy oddziałuje głównie inna polityka - Wspólna Polityka Rolna, której wątku nie podjęto w tej pracy (a o której piszą np. Czyżewski, Stępień [2011]).
} 
Wykres 6.2.1c. Wpływ funduszy na wskaźnik zatrudnienia mężczyzn $w$ pkt proc.

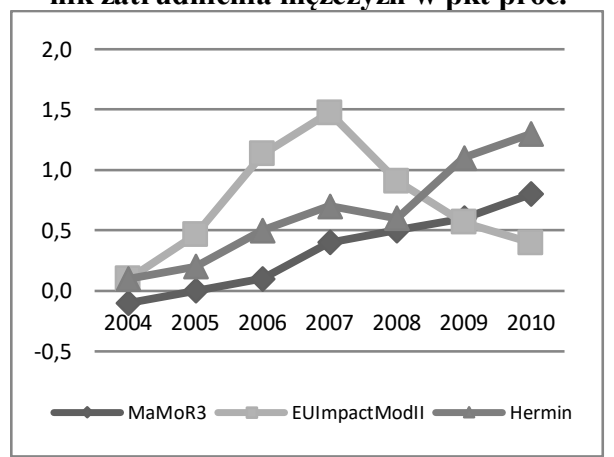

Wykres 6.2.1e. Wpływ funduszy na udzial zatrudnionych w przemyśle w pkt proc.

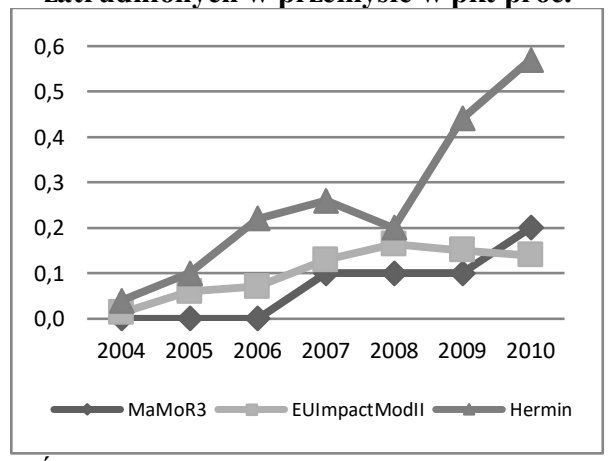

Wykres 6.2.1d. Wpływ funduszy na wskaźnik zatrudnienia kobiet $\mathrm{w}$ pkt proc.

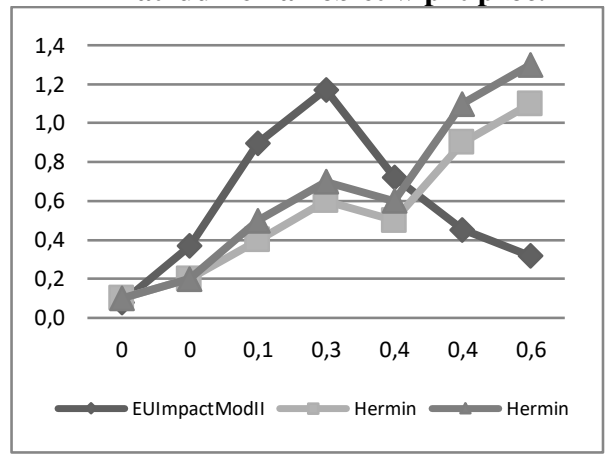

Wykres 6.2.1f. Wpływ funduszy na udzial zatrudnionych $w$ usługach $w$ pkt proc.

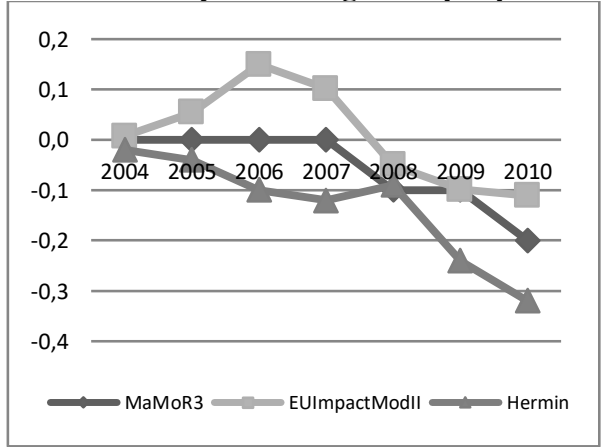

Źródło: opracowanie własne na podstawie wyników z modeli wymienionych w przypisie nr 3

Z tabeli 6.2.1 wynika, że tempa wzrostu wymienionych w niej wskaźnikówstymulant wzrostu gospodarczego byłyby generalnie niższe, gdyby polityka spójności nie była realizowana. Do wyjątków należy udział zatrudnionych w usługach, który rósłby w tempie minimalnie wyższym w przypadku braku funduszy. 


\subsection{Wpływ polityki spójności na polskie regiony i ich konwergencje}

Wyniki przedstawione w rozdziale 6.2 pokazują pozytywny wpływ polityki spójności na gospodarkę Polski. Szybszy rozwój całego kraju jest wynikiem faktu, że poszczególne województwa Polski zanotowały przyspieszony wzrost po akcesji do Unii, a wyniki modeli służących ewaluacji polityki spójności pokazują, że pewna część tych wzrostów jest rezultatem oddziaływania polityki spójności. Powstaje pytanie, czy siła i kierunek zmian, które dokonują się w województwach pod wpływem polityki spójności sprzyjają konwergencji, czy przeciwnie - powodują narastanie istniejących nierówności.

Badanie wpływu polityki spójności w regionach Polski przeprowadzono w oparciu o kryteria ewaluacyjne wymienione w rozdziale 5.3: trafność, skuteczność, użyteczność, efektywność ${ }^{6}$. Należy zauważyć, że ocenie podlegał głównie wpływ środków z okresu programowania NPR 2004-2006, pomimo że w roku pisania niniejszego rozdziału (2012), już od kilku lat wykorzystywano środki z transzy 2007-2013. Lecz w przypadku wojewódzkich PKB per capita, będących przedmiotem poniższej analizy, dwuletnie opóźnienie w publikacji danych z rachunków regionalnych spowodowało, że faktyczny (ex post) wpływ tej polityki mógł być empirycznie zbadany dla lat 2004-2009, czyli okresu oddziaływania przede wszystkim NPR 2004-2006

Kluczowe dla poniższych analiz jest przypisanie poszczególnym kryteriom ewaluacyjnym wymienionym na rysunku 5.3.1 - ich znaczenia w kontekście realizacji polityki spójności, czego schematycznym wyrazem był rysunek 5.3.2. Poniżej zsyntetyzowano oba te schematy, zapisując powiązanie ogólnych kryteriów ewaluacyjnych (z wykresu 5.3.1) z ogólnie pojętymi celami projektów (z wykresu 5.3.2) - w kontekście oceny konwergencji gospodarczej regionów Polski - por. rys. 6.3.1.

\footnotetext{
${ }^{6} \mathrm{Na}$ podstawie danych podlegających analizie w niniejszej książce nie można przeprowadzić badania trwałości projektów. Można jedynie powołać się na różnego rodzaju raporty (np. Drążkiewicz i in. [2007], [2010], [2011]), które badają ten efekt w różnych obszarach oddziaływania funduszy (analizy takie prowadzone są najczęściej na podstawie danych pierwotnych - ankietowych - przeprowadzanych na użytek konkretnych badań).

${ }^{7}$ Z dużym prawdopodobieństwem można stwierdzić, że dane o PKB za lata 2004-2009 zawierają w sobie wpływ głównie pierwszego okresu programowania. Wynika to z faktu, że po pierwsze zdecydowaną większość wydatków z tego okresu zrealizowano w latach 2006-2009, a po drugie, że pierwsze znaczące kwoty z NSRO 2007-2013 przekazano beneficjentom dopiero na przełomie lat 2009-2010.
} 
Rys. 6.3.1. Ocena konwergencji wewnętrznej w kontekście kryteriów ewaluacyjnych

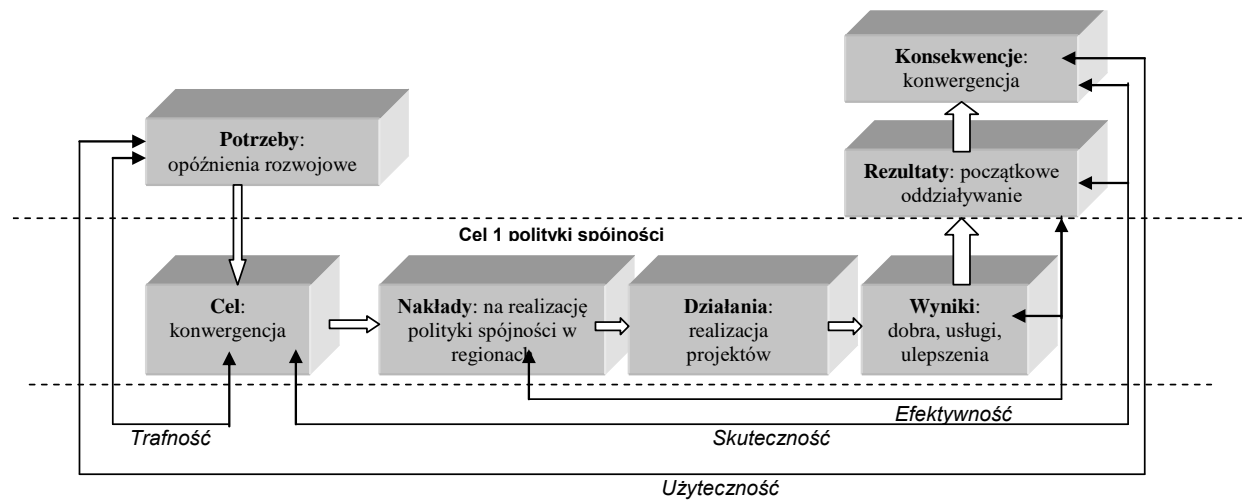

Źródło: opracowanie własne na podstawie Ewaluacja programów...,[1997], s. 18

\subsubsection{Trafność}

Zgodnie z rys. 6.3 .1 badanie trafności (relevance) interwencji powinno pozwolić na ocenę, wjakim stopniu cele programu odpowiadają potrzebom i priorytetom danego obszaru. „Polityka spójności ma na celu wspieranie dziatań prowadzacych do wyrównania warunków ekonomicznych i społecznych we wszystkich regionach Unii Europejskiej. W szczególności Unia Europejska zmierza do zmniejszenia różnic $w$ poziomie rozwoju regionów oraz likwidacji zacofania najmniej uprzywilejowanych regionów" (por. www.funduszeeuropejskie.gov.pl/WstepDoFunduszyEuropejskich/Strony/Cele PolitykiSpojnosci.aspx). Ten ogólnie sformułowany cel należało zoperacjonalizować do postaci nadającej się do analitycznej weryfikacji. Jest nim osiąganie konwergencji gospodarczej, a dokładnie konwergencji regionalnych PKB per capita ${ }^{8}$.

Badanie trafności interwencji wymaga również zoperacjonalizowania potrzeb, które zdefiniowano wg takiego samego kryterium jakie stosuje Komisja Europejska do kwalifikacji regionów NUTS 2 do realizacji głównego celu polityki spójności: poniżej 75\% PKB per capita w pps liczonego w stosunku do średniej UE. Ponieważ wszystkie regiony Polski zakwalifikowały się w ten sposób do realizacji celu 1 , zatem aby zróżnicować te potrzeby na terenie Polski przyjęto,

\footnotetext{
${ }^{8}$ Konwergencja gospodarcza nie wyczerpuje wszystkich zadań stawianych przez polityką spójności, które, jak podaje przytoczona definicja, powinny również dotyczyć wyrównywania różnic społecznych. Lecz, jak już wielokrotnie wspominano, w pracy tej podjęto jedynie wątek gospodarczy.
} 
że potrzeby regionalne są tym większe im niższe jest PKB per capita danego regionu.

Aby zatem pozytywnie zweryfikować hipotezę o trafności należałoby wykazać, że większe środki na realizację polityki spójności trafiły do regionów o największych potrzebach. Odpowiednie zestawienie prezentuje tabela 6.3.1, w której pokazano najpierw wojewódzkie wartości PKB per capita w stosunku do średniej unijnej. Wynika z niej, że w 2003 r. (w roku poprzedzającym akcesję do Unii) żaden region NUTS 2 nie przekraczał 75\% średniej dla UE $25-$ wszystkie zostały zakwalifikowane do realizacji celu 1 polityki spójności. Wedhug tego kryterium potrzeby wszystkich województw zostały potraktowane jednakowo, pomimo, że dystans pomiędzy województwem o najwyższym (mazowieckie) i najniższym (podkarpackie, lubelskie) PKB per capita w stosunku do UE był ponad dwukrotny.

Tabela 6.3.1. Porównanie wartości PKB per capita do wartości bezpośredniej alokacji środków w ramach NPR 2004-2006

\begin{tabular}{|c|c|c|}
\hline Województwo & $\begin{array}{c}\text { PKB per capita (w pps) } \\
\text { w stosunku do średniej unijnej } \\
\text { (UE25 w pps) w } 2003 \text { r. w \% }\end{array}$ & $\begin{array}{c}\text { Regionalny rozkład łącznej warto- } \\
\text { ści projektów (w zł na mieszkańca) } \\
\text { z NPR 2004-2006 }\end{array}$ \\
\hline dolnośląskie & 48 & 2949 \\
\hline kujawsko-pomorskie & 42 & 2344 \\
\hline lubelskie & 33 & 1901 \\
\hline lubuskie & 41 & 2363 \\
\hline łódzkie & 43 & 2646 \\
\hline małopolskie & 40 & 1669 \\
\hline mazowieckie & 73 & 3330 \\
\hline opolskie & 37 & 1807 \\
\hline podkarpackie & 33 & 1656 \\
\hline podlaskie & 36 & 2070 \\
\hline pomorskie & 46 & 2706 \\
\hline śląskie & 51 & 2877 \\
\hline świętokrzyskie & 37 & 1964 \\
\hline warmińsko-mazurskie & 37 & 2598 \\
\hline wielkopolskie & 49 & 2396 \\
\hline zachodniopom. & 44 & 3399 \\
\hline Wsp. korelacji & & $+0,73$ \\
\hline
\end{tabular}

Źródło: opracowanie własne na podstawie danych z Eurostatu oraz tabeli 4.4.2.1

Ocena trafności polityki spójności powinna być przeprowadzona z punktu widzenia dwóch perspektyw: krajowej i unijnej. Z punktu widzenia UE potrzeby, wynikające z opóźnienia rozwojowego, które w porównaniu do średniej UE, charakteryzują wszystkie regiony Polski - są zgodne z celami programu, tzn. z osiąganiem większej spójności wśród wszystkich europejskich regionów NUTS 2 (rzeczywiście, wszystkie regiony zmniejszyły swój dystans w stosunku do UE). Lecz szybkość tej zmiany nie była jednakowa - należałoby oczekiwać, 
aby regiony o najniższych wartościach PKB per capita (druga kolumna tabeli 6.3.1) nadrabiały dystans szybciej niż inne. Inaczej mówiąc, z krajowego punktu widzenia, potrzeby regionalne nie były takie same. Te zróżnicowane potrzeby, zdecydowanie większe na wschodzie kraju, nie zostały zmaterializowane w wielkości wsparcia - zarówno planowane alokacje, jak i ostateczne wykorzystanie środków (z tabeli 6.3.1) wskazuje, że trafiły one do województw najbogatszych (por. tabela 4.4.2.1). Takie rozlokowanie środków nie sprzyjało osiąganiu konwergencji - w każdym razie nie bezpośrednio, bowiem większe środki nie trafiały do województw o gorszej sytuacji gospodarczej.

Powstaje pytanie, czy rozdział środków na rozwój regionalny w bieżącej perspektywie finansowej (2007-2013) poprawia trafność ich alokacji, tzn. czy stosunkowo większe kwoty zarezerwowano dla województw o największych potrzebach (najniższym PKB per capita). Odpowiedź na to pytanie jest pozytywna. Pomimo użycia identycznego, co w NRP 2004-2006 algorytmu 80/10/109, planowany w NSRO 2007-2013 rozdział środków regionalnych, daje najbiedniejszym regionom - Polski Wschodniej - największy przydział funduszy na osobę $^{10}$ - zob. ostatnia kolumna tabeli 4.4.2.2.

Zatem, przynajmniej teoretycznie (bo o ostatecznym podziale środków decyduje aktywność województw w ich pozyskiwaniu), rozdział środków regionalnych z perspektywy finansowej 2007-2013 charakteryzuje się większą trafnością niż w NPR 2004-2006. Z punktu widzenia celu 1 polityki spójności - konwergencji, większe dofinansowanie powinny dostawać te województwa, które mają większe potrzeby (niższe PKB per capita), co powinno się przyczynić do ich szybszego wzrostu i wyrównania różnic międzyregionalnych ${ }^{11}$. Różnice pomiędzy trafnością dedykowania pomocy unijnej w latach 2004-2006 i 2007-2013 syntetycznie określa współczynnik korelacji pomiędzy wartością wsparcia regionalnego per capita, a sytuacją województwa mierzoną PKB per capita. Dla programu NPR 2004-2006, korelacja ta była dodatnia i istotna statystycznie (jak widać z ostatniej komórki tabeli 6.3.1 wynosiła $+0,73$ ), co oznacza, że im wyższe było wojewódzkie PKB per capita, tym wyższe otrzymywało dofinansowanie na osobę - co nie sprzyja konwergencji. Dla planowanych w NSRO 2007-2013 alokacji regionalnych korelacja ta (pomiędzy planowaną alokacją wojewódzką raportowaną $\mathrm{w}$ tabeli 4.4.2.2, a sytuacją województw mierzoną PKB per capita) wynosi - 0,60 - jest ujemna i istotna statystycznie, co pozwala

\footnotetext{
${ }^{9}$ Polegającego na tym, że wszystkie regiony uczestniczą w podziale $80 \%$ ogółu środków według liczby ludności, a tylko 20\% środków rozdzielanych jest wg kryterium niskiego PKB na 1 mieszkańca i wysokiej stopy bezrobocia.

${ }^{10}$ Dzieje się tak $\mathrm{z}$ powodu uruchomienia specjalnych programów dla województw Polski Wschodniej.

${ }^{11}$ Pominięto na razie kwestie efektywności takiej alokacji, którą podjęto na końcu tego podrozdziału oraz w p. 6.3.4.
} 
stwierdzić, że większe środki, przynajmniej z programów regionalnych ${ }^{12}$, trafią do tych województw, które charakteryzuje gorsza sytuacja gospodarcza.

Zupełnie inną kwestią pozostaje efektywność takiej alokacji. Istnieją bowiem duże rozbieżności poglądów co do skuteczności polityki polegającej na wspieraniu regionów opóźnionych. Istnieją takie, które głoszą, że efektywność wykorzystania środków w takich regionach jest mniejsza, a to samo wsparcie udzielone prężnie rozwijającym się jednostkom nie tylko będzie lepiej wykorzystane, lecz również może skutkować dyfuzją na inne regiony (podejście redystrybucyjne vs efektywnościowe, na które duży nacisk kładą zwolennicy Nowej Geografii Ekonomicznej). Wątek ten znalazł swoją kontynuację w podrozdziale 6.3.4.

\subsubsection{Użyteczność}

Badanie użyteczności (utility) programów powinno pozwolić na ocenę, do jakiego stopnia rezultaty programu odpowiadają potrzebom grupy docelowej. Ponieważ potrzeby zdefiniowano w poprzednim podrozdziale (wg kryterium PKB per capita), pozostaje zoperacjonalizowanie rezultatów działania polityki spójności. Przyjęto, że jest to ta część wzrostu PKB w regionach, którą można przypisać realizacji polityki spójności. Jak pisano w rozdziale 5.1, w przypadku polityki spójności o tak różnorodnych wynikach (dobrach, usługach, ulepszeniach) nie jest możliwa jej ocena inna niż poprzez modele makroekonomiczne. Jak już wcześniej wspominano na ich podstawie formułuje się scenariusze gospodarcze, w których podaje się wartości badanych zmiennych przy wykorzystaniu środków oraz wartości w scenariuszu, który zakłada brak badanego dofinansowania. Różnica pomiędzy tymi scenariuszami jest wpływem polityki na badane zjawisko. Różnicę tę, wyliczoną na podstawie trzech różnych modeli opisywanych w podrozdziale 5.1.2, pokazuje tabela 6.3.2.1.

Z tabeli tej wynika, że stosunkowo „najostrożniej” ocenia wpływ funduszy model MaMoR - średnio wpływ ten wynosi 0,9 punktu procentowego, podczas gdy w model EuImpactMod jest to średnio 2,2 punktu. Stosunkowo zgodne, co do korzyści jakie odnoszą poszczególne województwa z realizacji polityki spójności, są wyniki z modeli MaMoR i EuImpactMod (co wynika m.in. z faktu, że

\footnotetext{
${ }^{12}$ Należy pamiętać, że ostateczna alokacja środków zależy od aktywności województw w ich pozyskiwaniu. Z danych Ministerstwa Rozwoju Regionalnego obejmujących okres do końca 2010 r. wynika, że aktywność 5 najbogatszych województw w pozyskiwaniu ogółu środków jest wyższa niż w 5 najuboższych (do końca 2010 r. płatności ze środków unijnych na rzecz beneficjentów wynosiły 11415 mln $€$, z czego $47 \%$ stanowiły wydatki w 5 najbogatszych, a tylko $25 \%$ w 5 najuboższych województwach). Jednakże znacznie większa pula zarezerwowana dla Polski Wschodniej (która stanowi ponad 12\% całości środków z UE na realizację polityki spójności) powoduje, że jest mało prawdopodobne, aby ostateczny rozdział środków spowodował ich alokację jak poprzednio - kiedy to województwa Polski Wschodniej pozyskały jedynie 15\% ogólnego wsparcia.
} 
reprezentują one ten sam typ modelu - równowagi ogólnej), zaś najmniej porównywalne są wyniki z modeli HERMIN i MaMoR.

Tabela 6.3.2.1 Skumulowany wpływ polityki spójności w 2009 r. na PKB per capita w pps w stosunku do średniej unijnej wg różnych modeli (w punktach procentowych)

\begin{tabular}{|c|c|c|c|}
\hline Województwo & $\begin{array}{c}\text { Wplyw na PKB pc } 2009 \\
\text { (UE27=100) } \\
\text { wg Hermin } \\
\end{array}$ & $\begin{array}{c}\text { Wplyw na PKB pc } 2009 \\
\text { (UE27=100) } \\
\text { wg MaMoR } \\
\end{array}$ & $\begin{array}{c}\text { Wpływ na PKB pc } 2009 \\
\text { (UE25=100) } \\
\text { wg EuImpactMod }\end{array}$ \\
\hline dolnośląskie & 1,4 & 1,0 & 1,9 \\
\hline kujawsko-pomorskie & 1,1 & 0,8 & 1,4 \\
\hline lubelskie & 2,7 & 0,5 & 1,6 \\
\hline lubuskie & 0,8 & 1,5 & 3,4 \\
\hline łódzkie & 1,1 & 0,9 & 2,2 \\
\hline małopolskie & 1,0 & 0,8 & 1,2 \\
\hline mazowieckie & 2,9 & 1,0 & 2,7 \\
\hline opolskie & 1,2 & 0,5 & 1,9 \\
\hline podkarpackie & 1,0 & 0,8 & 1,6 \\
\hline podlaskie & 0,9 & 0,6 & 1,8 \\
\hline pomorskie & 2,6 & 1,3 & 2,8 \\
\hline śląskie & 2,1 & 1,2 & 1,7 \\
\hline świętokrzyskie & 1,0 & 0,7 & 1,8 \\
\hline warmińsko-mazurskie & 1,5 & 1,1 & 3,0 \\
\hline wielkopolskie & 1,6 & 1,1 & 2,1 \\
\hline zachodniopomorskie & 3,1 & 1,1 & 3,7 \\
\hline Średnia & 1,6 & 0,9 & 2,2 \\
\hline
\end{tabular}

Źródło: opracowanie własne na podstawie danych z tabeli 1.4 raportu Zaleskiego i in. [2011, s. 45] (model HERMIN), tablicy 37 raportu Kaczora i in. [2012, s.27-28] (model MaMoR), tablicy 10 raportu Bukowskiego, Wierusa [2012, s. 57] (model EuImpactMod)

W celu oceny użyteczności, należy postawić pytanie: czy wpływ funduszy był największy w województwach o najwyższych potrzebach (najniższym PKB per capita)? W celu odpowiedzi na to pytanie porównano dane o efektach oddziaływania polityki spójności na PKB per capita (z tabeli 6.3.2.1) z danymi o PKB per capita województw w roku poprzedzającym realizację polityki spójności (ukazane w tabeli 6.3.1). Należało wcześniej rozstrzygnąć, czy do porównań należy użyć bezwzględnego, czy względnego wpływu na PKB. Wartości z tabeli 6.3.2.1 pokazują bezwzględną różnicę $\mathrm{w}$ dwóch scenariuszach (bez funduszy i z funduszami), która jest uzależniona od początkowej sytuacji województwa mierzonej PKB pc. w roku 2003. Ostatecznie uznano, że właściwsze będzie porównanie względnego wpływu polityki spójności, który wyliczono jako udział wartości z tabeli 6.3.2.1 w wartości PKB per capita w województwach wynikającymi ze scenariusza bez funduszy (które są podawane przez autorów raportów wymienionych w źródle do tabeli 6.3.2.1) - por. tabela 6.3.2.2. 
Tabela 6.3.2.2 Skumulowany wpływ polityki spójności w 2009 r. na PKB per capita w pps w stosunku do średniej unijnej wg różnych modeli (w \% - w stosunku do scenariusza bez funduszy z 2009 r.)

\begin{tabular}{|l|r|r|r|}
\hline \multicolumn{1}{|c|}{ Województwo } & $\begin{array}{c}\text { Wpływ na PKB pc } 2009 \\
\text { w (UE27=100) } \\
\text { wg Hermin }\end{array}$ & $\begin{array}{c}\text { Wplyw na PKB pc } 2009 \\
\text { (UE27=100) } \\
\text { Wg MaMoR }\end{array}$ & $\begin{array}{c}\text { Wplyw na PKB pc 2009 } \\
\text { (UE25=100) } \\
\text { wg EuImpactMod }\end{array}$ \\
\hline dolnośląskie & 2,2 & 1,5 & 3,1 \\
\hline kujawsko-pomorskie & 2,2 & 1,6 & 2,9 \\
\hline lubelskie & 7,1 & 1,2 & 4,2 \\
\hline lubuskie & 1,6 & 3,0 & 7,0 \\
\hline tódzkie & 2,0 & 1,6 & 4,2 \\
\hline małopolskie & 2,0 & 1,6 & 2,4 \\
\hline mazowieckie & 3,1 & 1,0 & 2,9 \\
\hline opolskie & 2,5 & 1,0 & 4,3 \\
\hline podkarpackie & 2,5 & 2,0 & 4,1 \\
\hline podlaskie & 2,1 & 1,4 & 4,3 \\
\hline pomorskie & 4,6 & 2,2 & 5,1 \\
\hline śląskie & 3,3 & 1,9 & 2,8 \\
\hline świętokrzyskie & 2,2 & 1,5 & 4,2 \\
\hline warmińsko-mazurskie & 3,5 & 2,5 & 7,4 \\
\hline wielkopolskie & 2,6 & 1,7 & 3,6 \\
\hline zachodniopomorskie & 6,2 & 2,1 & 7,7 \\
\hline Korelacja z PKB pc 2003 & $\mathbf{0 , 0 5}$ & $\mathbf{- 0 , 2 1}$ & $\mathbf{- 0 , 3 0}$ \\
\hline
\end{tabular}

Źródło: obliczenia własne na podstawie danych z raportów wymienionych w źródle do tabeli 6.3.2.1

Współczynniki korelacji pomiędzy procentową wielkością wpływu polityki spójności na PKB per capita, a początkową sytuacją województw, tzn. PKB per capita w stosunku do UE 25 w roku 2003 (por. druga kolumna tabeli 6.3.1) są ujemne, lecz nieistotne statystycznie ${ }^{13}$. Z powodu braku istotności należy stwierdzić, że nie ma istotnego powiązania pomiędzy początkową sytuacją województw mierzoną PKB per capita a wpływem polityki spójności na ten wskaźnik. Gdyby zignorować fakt nieistotności, można byłoby powiedzieć, że wpływ polityki był największy w tych województwach, w których początkowa sytuacja była najgorsza - co byłoby argumentem za użytecznością regionalnych programów (w ramach wsparcia z NPR 2004-2006).

\subsubsection{Skuteczność}

Badanie skuteczności (effectiveness) powinno pozwolić na ocenę, do jakiego stopnia cele przedsięwzięcia zdefiniowane na etapie jego programowania zostały odzwierciedlone w jego rezultatach i konsekwencjach. Jest to kluczowe, z punktu widzenia konwergencji, kryterium ewaluacyjne, bowiem pozwala oce-

${ }^{13}$ Przy czym nie ma znaczenia, czy będą to korelacje $\mathrm{z}$ PKB per capita w odniesieniu do UE 15, UE 25, czy UE 27 (dynamika takich wskaźników jest taka sama, zmienia się tylko ich wartość). 
nić, czy główny cel polityki spójności - zmniejszenie nierówności gospodarczych w regionach - został osiągnięty ${ }^{14}$.

W rozdziale 3. zbadano konwergencję PKB per capita wśród polskich województw i stwierdzono, że ten proces nie zachodzi. Czy to znaczy, że polityka spójności „nie działa”, a ostrożniej formułując to stwierdzenie, że jej oddziaływanie nie jest zgodne z celami? Odpowiedź wcale nie jest oczywista, bowiem pytanie o wpływ polityki spójności na konwergencję wewnętrzną w Polsce powinno być inaczej sformułowane. W istocie należy zapytać, czy dywergencja pomiędzy regionami w Polsce byłaby wyższa, gdyby polityka spójności nie była realizowana, bowiem $\mathrm{z}$ analiz przeprowadzonych $\mathrm{w}$ rozdziale 3 . wynika, że proces zwiększania dysproporcji wojewódzkich PKB per capita trwa przynajmniej od 1995 r. Należy zastanowić się również, czy w ogóle należy oczekiwać w Polsce pozytywnego wpływu polityki spójności na zmniejszanie zróżnicowania pomiędzy jej regionami? Głównym powodem wątpliwości zawartej w ostatnim pytaniu jest fakt, że w Polsce celem „Konwergencja” objęte są wszystkie województwa, zatem wszystkie otrzymują środki na wyrównywanie różnic. Jak pokazano w podrozdziale 6.3.1 rozdział środków z pierwszego okresu programowania nie sprzyjał osiąganiu konwergencji (województwa o niższych dochodach nie otrzymały wyższego finansowanie niż te o wyższych).

W celu zweryfikowania hipotezy o skuteczności polityki spójności i odpowiedzi na powyższe wątpliwości, ponownie posłużono się wynikami z modeli oceniających wpływ tej polityki - zawężając analizy konwergencji, które w rozdziale 3 były prowadzone dla lat 1995-2010, do okresu 2003-2009 (rok 2003 jest ostatnim w którym nie realizowano jeszcze polityki spójności, rok 2009 - ostatnim, dla którego pochodzą dane faktyczne o wartościach PKB w województwach). Dzięki danym o wartości wojewódzkich PKB per capita w scenariuszu zakładającym brak realizacji polityki spójności w roku 2009 oraz danym faktycznym dla tego roku (z definicji zawierającym wpływ tej polityki) można było ocenić procesy konwergencji $\mathrm{w}$ dwóch scenariuszach rozwoju gospodarki Polski. W tym celu porównano współczynniki regresji modelu betakonwergencji absolutnej dla danych w tych dwóch scenariuszach - por. tabela 6.3.3.

\footnotetext{
${ }^{14} \mathrm{~W}$ artykule Gorzelaka [2008] postuluje się oddzielanie zjawiska konwergencji od spójności. W pracy tej wyraźnie zdefiniowano i zoperacjonalizowane (w rozdziale 2) pojęcie konwergencji i jeśli pojawia się w tym kontekście określenie spójności to tylko w wąskim znaczeniu - konwergencji.
} 
Tabela 6.3.3. Współczynnik $\boldsymbol{b}$ w regresji modelu beta-konwergencji postaci

\begin{tabular}{|l|c|c|}
$\ln \left(\frac{P K B_{-} p c_{i, 2009}}{P K B_{-} p c_{i, 2003}}\right)$ & $=a+b \ln \left(P K B_{-} p c_{i, 2003}\right)$ w dwóch scenariuszach \\
\hline \multicolumn{1}{|c|}{ Model } & $\begin{array}{c}\text { Scenariusz zakladający brak } \\
\text { realizacji polityki spójności }\end{array}$ & $\begin{array}{c}\text { Scenariusz zakladający reali- } \\
\text { zację polityki spójności }^{15}\end{array}$ \\
\hline Hermin & 0,093 & 0,090 \\
\hline MaMoR & 0,094 & 0,090 \\
\hline EuImpactMod & 0,113 & 0,090 \\
\hline
\end{tabular}

Źródło: opracowanie własne na podstawie raportów wymienionych w źródle do tabeli 6.3.2.1

Wszystkie współczynniki w tabeli 6.3 .3 są dodatnie, co wskazuje na brak konwergencji, a nawet na dywergencję PKB per capita w okresie 2003-2009 ${ }^{16}$ bez względu na realizowany scenariusz. Interesujące jest natomiast, że w przypadku scenariusza „bez funduszy” dywergencja jest większa niż w scenariuszu „z funduszami”. Różnice w modelach są jednakże minimalne (największe dla modelu EuImpactMod). Ostatecznie można stwierdzić, że realizacja NPR 2004-2009 (a jak wcześniej stwierdzono dostępne dane z rachunków narodowych - do 2009 r. - zawierają realizację przede wszystkim tego programu, z minimalnym tylko wpływem NSRO 2007-2013) zmniejsza natężenie procesów dywergencyjnych wśród polskich województw, choć zmiany te są na razie bardzo subtelne.

\subsubsection{Efektywność}

Efektywność (efficiency) powinna pozwolić na odpowiedź na pytanie: jak oszczędnie poszczególne nakłady zostały przekształcone w wyniki i rezultaty? (por. Ewaluacja programów...[1997, s. 17]). W celu odpowiedzi na nie policzono współczynnik efektywności, który jest ilorazem pomiędzy poniesionymi nakładami a rezultatami. Zgodnie z rys. 5.3.2 rezultaty polityki spójności określono jako wzrost PKB per capita, który można przypisać realizacji polityki spójności. Nakłady zmierzono dwojako - jako wartość (per capita) zrealizowanych w ramach NPR 2004-2006 projektów oraz jako udział tych inwestycji w wartości PKB (stopa inwestycji).

Porównanie wartości projektów (nakłady) i uzyskanego w regionach wyniku efektu w postaci wzrostu PKB znajduje się w tabeli 6.3.4.1.

\footnotetext{
${ }^{15}$ Identyczne wartości w tej kolumnie wynikają z faktu, że w scenariuszu zakładającym realizację polityki spójności były brane pod uwagę faktyczne wartości PKB, w których założono, że wpływ polityki spójności jest już uwzględniony.

${ }^{16}$ Należy jednakże zaznaczyć, że współczynnik przy zmiennej objaśniającej jest nieistotny statystycznie.
} 
Tabela 6.3.4.1. Zestawienie wartości zrealizowanych w ramach NPR 2004-2006 projektów oraz wpływu polityki spójności na PKB per capita w stosunku do średniej unijnej

\begin{tabular}{|l|r|r|r|r|}
\hline \multicolumn{1}{|c|}{ Województwo } & $\begin{array}{c}\text { Wartość projek- } \\
\text { tów z NPR w zl } \\
\text { per capita }\end{array}$ & $\begin{array}{c}\text { Wplyw wg } \\
\text { Hermin w pp. }\end{array}$ & $\begin{array}{c}\text { Wplyw wg } \\
\text { MaMoR w pp. }\end{array}$ & $\begin{array}{c}\text { Wpływ wg Eu- } \\
\text { Impact w pp. }\end{array}$ \\
\hline dolnośląskie & 2949 & 1,4 & 1,0 & 1,9 \\
\hline kujawsko-pom. & 2344 & 1,1 & 0,8 & 1,4 \\
\hline lubelskie & 1901 & 2,7 & 0,5 & 1,6 \\
\hline lubuskie & 2363 & 0,8 & 0,9 & 3,4 \\
\hline łódzkie & 2646 & 1,1 & 0,8 & 2,2 \\
\hline małopolskie & 1669 & 1,0 & 1,0 & 1,2 \\
\hline mazowieckie & 3330 & 2,9 & 0,5 & 2,7 \\
\hline opolskie & 1807 & 1,2 & 0,8 & 1,9 \\
\hline podkarpackie & 1656 & 1,0 & 0,6 & 1,6 \\
\hline podlaskie & 2070 & 0,9 & 1,3 & 1,8 \\
\hline pomorskie & 2706 & 2,6 & 1,2 & 2,8 \\
\hline śląskie & 2877 & 2,1 & 0,7 & 1,7 \\
\hline świętokrzyskie & 1964 & 1,0 & 1,1 & 1,8 \\
\hline warmińsko-maz. & 2598 & 1,5 & 1,1 & 3,0 \\
\hline wielkopolskie & 2396 & 1,6 & 1,1 & 2,1 \\
\hline zachodniopom. & 3399 & 3,1 & $\mathbf{0 , 5 9}$ & 3,7 \\
\hline Korelacja z wielkością wsparcia pc. & & $\mathbf{0 , 6 3}$ & $\mathbf{0 , 6 4}$ \\
\hline
\end{tabular}

Źródło: opracowanie własne na podstawie danych $\mathrm{z}$ tabeli 4.4.2.1 oraz 6.3.2.1

Współczynniki korelacji z ostatniego wiersza tabeli 6.3.4.1 są dodatnie, co pozwala stwierdzić, że im większa była alokacja regionalna tym lepsze były efekty realizacji polityki spójności (w postaci bezwzględnego wzrostu PKB per capita $)^{17}$. Fakt ten świadczy na korzyść efektywności polityki spójności (tam, gdzie przeznaczono największe środki na realizację polityki spójności uzyskano również największy jej wpływ). Powyższy wynik nie pozwala jednakże stwierdzić w którym województwie efektywność wydatkowania środków była największa. O relacji wyników i nakładów bardziej wymownie świadczą dane z tabeli 6.3.4.2, w której wielkość wsparcia per capita przeliczono na wzrosty PKB per capita wywołane realizacją polityki spójności o 1 punkt procentowy.

${ }^{17} \mathrm{~W}$ odniesieniu do procentowych przyrostów PKB per capita wywołanych realizacją polityki spójności współczynniki korelacji są niższe (wynoszą odpowiednio 0,$26 ; 0,15 ; 0,23$ ), lecz również dodatnie. 
Tabela 6.3.3.2. Przeliczenie wartości projektów per capita (z tabeli 6.3.4.1) na 1 punkt procentowy wzrostu PKB per capita wywolanego realizacją polityki spójności

\begin{tabular}{|c|c|c|c|c|c|c|}
\hline & \multicolumn{3}{|c|}{$\begin{array}{l}\text { Wartość projektów pc. w przelicze- } \\
\text { niu na 1pp. wzrostu PKB wywolany } \\
\text { polityką spójności wg modelu: }\end{array}$} & \multicolumn{3}{|c|}{ Pozycja efektywności wg: } \\
\hline & Hermin & MaMoR & EuImpact & Hermin & MaMoR & EuImpact \\
\hline dolnośląskie & 1340 & 1966 & 951 & 15 & 15 & 14 \\
\hline kujawsko-pom. & 1065 & 1465 & 808 & 12 & 8 & 13 \\
\hline lubelskie & 268 & 1584 & 453 & 1 & 11 & 6 \\
\hline lubuskie & 1477 & 788 & 338 & 16 & 1 & 1 \\
\hline łódzkie & 1323 & 1654 & 630 & 14 & 13 & 10 \\
\hline małopolskie & 835 & 1043 & 695 & 7 & 4 & 12 \\
\hline mazowieckie & 1074 & 3330 & 1148 & 13 & 16 & 16 \\
\hline opolskie & 723 & 1807 & 420 & 5 & 14 & 4 \\
\hline podkarpackie & 662 & 828 & 404 & 4 & 2 & 3 \\
\hline podlaskie & 986 & 1479 & 481 & 11 & 9 & 8 \\
\hline pomorskie & 588 & 1230 & 531 & 3 & 5 & 9 \\
\hline śląskie & 872 & 1514 & 1028 & 8 & 10 & 15 \\
\hline świętokrzyskie & 893 & 1309 & 468 & 9 & 6 & 7 \\
\hline warmińsko-maz. & 742 & 1039 & 351 & 6 & 3 & 2 \\
\hline wielkopolskie & 922 & 1409 & 666 & 10 & 7 & 11 \\
\hline zachodniopom. & 548 & 1619 & 441 & 2 & 12 & 5 \\
\hline
\end{tabular}

Źródło: obliczenia własne na podstawie danych z tabeli 6.3.2.2 i 6.3.4.1

$\mathrm{Z}$ powyższego zestawienia wynika, że stosunkowo najmniej efektywne (tzn. charakteryzujące się wysoką wartością nakładów do wyników) było dofinansowanie kierowane do województw: dolnośląskiego, łódzkiego, mazowieckiego, wielkopolskiego. Stosunkowo największą efektywnością wydatkowania środków z NPR charakteryzowały się takie województwa jak np. podkarpackie, czy warmińsko-mazurskie (co do reszty modele nie są zgodne, np. województwo lubuskie, które wg MaMoR i EuImpact charakteryzowało się największą efektywnością wg HERMIN - najmniejszą). Generalnie, nie można stwierdzić, że efektywność wykorzystania środków unijnych jest niższa w regionach opóźnionych. W grupie województw o najwyższej efektywności nie ma województw najzamożniejszych. Jest wręcz przeciwnie - aż trzy województwa o najwyższych dochodach: mazowieckie, dolnośląskie, wielkopolskie - charakteryzuje stosunkowo niska efektywność. A zatem, w przypadku polskich województw i perspektywy finansowej NPR 2004-2006, nie można potwierdzić, że efektywność wykorzystania środków w regionach ubogich jest mniejsza - co podkreślają przeciwnicy polityki spójności. Być może trwałość inwestycji oraz ich zdolność do podtrzymywania wzrostu po ustaniu finansowania jest w regionach najuboższych mniejsza - lecz efektu tego nie można zmierzyć za pomocą wykorzystywanych w tym rozdziale danych (por. przypis nr 6). 


\subsection{Podsumowanie}

$\mathrm{Wg}$ autorów $\mathrm{V}$ raportu kohezyjnego ,polityka spójności w znacznym stopniu przyczynita się do rozszerzenia strefy wzrostu gospodarczego $i$ dobrobytu na cała Unię, co z kolei wptynęto na zmniejszenie różnic gospodarczych, społecznych i terytorialnych.(...). Nie ulega wątpliwości, że bez polityki spójności dysproporcje bytyby większe (za: Komunikat Komisji do Parlamentu Europejskiego..., [2010, s. 2]).

$\mathrm{Z}$ badań przeprowadzonych $\mathrm{w}$ niniejszym rozdziale można $\mathrm{w}$ części potwierdzić powyższą tezę. Jak wynika z podrozdziału 6.3 .3 (gdzie wykorzystano analizy o wpływie polityki spójności na PKB dokonywane przez 3 niezależne ośrodki badawcze) realizacja polityki spójności pozwala osłabić, choć minimalnie, procesy dywergencji gospodarczej wśród polskich województw (co powoduje, że można twierdząco odpowiedzieć na ostatnie z pytań szczegółowych postawionych we wstępie). Różnice w zmniejszeniu nasilenia zjawiska dywergencji są nieznaczne, lecz szczególnie znamienne wobec wniosku o braku trafności programów regionalnych z okresu programowania z NPR 2004-2006 (co jest negatywną odpowiedzią na pytanie o trafność alokacji - zdefiniowanej jako korelacja wartości projektów z potrzebami województw mierzonymi PKB per capita). Pomimo, że środki nie trafiały w większym stopniu do regionów o najniższych wskaźnikach gospodarczych (co wynikało z przyjętego algorytmu ich przydzielania, polegającego głównie na kryterium wielkości populacji województw), to efektywność ich wykorzystania (w podrozdziale 6.3.4 pokazano, że korelacja pomiędzy wielkością wsparcia regionów a wzrostem PKB pc. z tytułu realizacji polityki spójności jest dodatnia) sprawiła, że proces dywergencji nie uległ zwiększeniu. Weryfikacja ostatniego z ewaluowanych kryteriów (odpowiadających na kolejne ze szczegółowych pytań badawczych postawionych we wstępie) - użyteczność polityki spójności nie przyniosła rozstrzygającego rezultatu; korelacja pomiędzy sytuacją gospodarczą województwa z okresu przed realizacją polityki spójności a rezultatami tej polityki była co prawda ujemna (co wskazuje, że wpływ realizacji polityki spójności był tym większy im gorsza była sytuacja początkowa województwa), lecz nieistotna statystycznie.

Niektórzy autorzy formułują większe nadzieje w związku z nowym okresem programowania: „wraz z zaangażowaniem w najniżej rozwiniętych regionach dużych środków zwiazanych z realizacja NSS 2007-2013, skumulowane oddziaływanie instrumentów polityki spójności powinno przełożyć się na spowolnienie procesów dywergencyjnych." (Wpływ funduszy europejskich... [2010, s. 8]). Trudno jednakże mówić o faktycznym wpływie tego okresu programowania na konwergencję, czy mówiąc precyzyjnie na istotne spowolnienie dywergencji, bowiem pierwsze znaczące środki na finansowanie programów z NSRO 20072013 uruchomione zostały dopiero w 2009 r. Jeśli chodzi o wpływ polityki 
spójności na konwergencję mierzoną PKB per capita, to limitacja danych $\mathrm{z}$ rachunków regionalnych spowodowała, że faktyczny wpływ tej polityki mógł być, w momencie pisania pracy, empirycznie zbadany dla lat 2004-2009, czyli okresu oddziaływania NPR 2004-2006. O ile zatem nie można mówić o jakiś generalnych zmianach $\mathrm{w}$ procesach dywergencji wywołanych realizacją NPR 2004-2006, to takie nadzieje daje NSRO 2007-2010. Niektóre badania wskazują (zob. Kusideł [2012b]), że dzięki realizacji programów regionalnych w ramach NSRO (w szczególności stworzenia specjalnych programów dla województw Polski Wschodniej), osłabienie tempa rozbieżności gospodarczej polskich województw powinno być, dzięki realizacji polityki spójności, wyraźniejsze. 


\section{ZAKOŃCZENIE}

Jeśli przyjąć, że konwergencja jest procesem doganiania (catch-up effect) bogatszych krajów (regionów) przez biedniejsze, to wyniki badań intensywnie prowadzonych w latach 80 i $90, \mathrm{XX}$ w. pozwalają na ostrożny wniosek, że w grupie krajów o podobnej strukturze, szybszego wzrostu doświadczają te z nich, które mają niższy początkowy poziom PKB per capita. Jednocześnie jednak badania wskazują, że pogłębiają się zróżnicowania wewnątrzkrajowe. Jest to dość typowa dla Unii Europejskiej rozbieżność - spadek zróżnicowania pomiędzy poszczególnymi krajami Unii Europejskiej (choć szybkość tego procesu jest niewielka), przy jednoczesnym rosnącym rozwarstwieniu pomiędzy poszczególnymi regionami NUTS 2 wewnątrz krajów. Polska nie jest pod tym względem wyjątkiem - doświadcza wzrostu gospodarczego, który pozwala jej na stosunkowo szybkie zmniejszanie dystansu w stosunku do średniej unijnej przy jednoczesnym rosnącym rozwarstwieniu wewnętrznym.

Pokazują to badania przeprowadzone w niniejszej książce - PKB per capita charakteryzuje beta-dywergencja i sigma-dywergencja. Oznacza to, że województwa o niższym, początkowym poziomie dochodu charakteryzują się mniejszymi tempami gospodarczego niż bogatsze, co uniemożliwia im ich doganianie. Rosną również dysproporcje wojewódzkich PKB per capita w czasie, a niektóre badania pokazują, że w ogóle nie należy spodziewać się odwrócenia tego negatywnego trendu w najbliższej przyszłości ${ }^{1}$.

Badania konwergencji w podziale na bardziej homogeniczne grupy województw pokazały, że główną przyczyną jej braku, jest rosnące zróżnicowanie nie tyle pomiędzy wszystkimi województwami, co pomiędzy ich grupami (klastrami). Gdy w badaniu wyodrębniono 4 grupy województw: o najwyższym, średnim, najniższym poziomie PKB per capita oraz województwo mazowieckie, to okazało się, że można stwierdzić konwergencję wewnątrz niektórych grup. Pokazano w ten sposób występowanie dochodowej konwergencji lokalnej, która polega na zbliżaniu się do siebie regionów o podobnych charakterystykach strukturalnych.

Badania konwergencji wydajności pracy - prowadzone równolegle $\mathrm{z}$ badaniami PKB per capita - pokazały, że regionalny rozkład produkcji wśród pracowników ją wytwarzających (mierzonej WDB na pracującego) jest inny niż wśród osób ją „konsumujących” (mierzonej PKB per capita). O ile w przypadku wszystkich badań dla PKB per capita stwierdzono (podobnie do wyników ba-

\footnotetext{
${ }^{1}$ Analizy symulacyjne z artykułu Kusideł [2013c] pokazują, że przy kontynuacji dotychczasowych trendów co do udziału PKB poszczególnych województw w całkowitym PKB Polski - regionalne nierówności gospodarcze będą się pogłębiać również w przyszłości (analizy dotyczyły horyzontu do roku 2020), co nie daje nadziei na szybkie osiągnięcie konwergencji.
} 
dań innych autorów) dywergencję (choć nie zawsze istotną statystycznie), to w przypadku wydajności pracy - w niektórych badaniach (po uwzględnieniu specyficznych dla województw czynników sugerowanych w modelu Solowa) stwierdzono konwergencję, wprawdzie nieistotną statystycznie, lecz pokazującą zbieżność (a nie rozbieżność) do stanu równowagi. Niskie tempo zbieżności wydajności pracy znalazło potwierdzenie $w$ badaniach stacjonarnych stanów równowagi (steady-state), w których zademonstrowano, że ich osiągnięcie zajmie województwom czas mierzony raczej w pokoleniach, niż w latach (czas potrzebny do zmniejszenia występujących różnic w wydajności pracy o połowę to 22-34 lata - ostateczny wynik zależy w dużym stopniu od sposobu parametryzacji modelu Solowa, na co w pracy zwrócono szczególną uwagę). Badanie ścieżek stanów równowagi pokazało, że taka analiza może być pomocna w wyróżnieniu wśród wielu analizowanych regionów takich ich grup, które rozpatrywane oddzielnie - charakteryzuje konwergencja (jest to niekonwencjonalne wykorzystanie analiz steady-state).

Różnice w wynikach dotyczących stanów równowagi, w zależności od parametryzacji modelu Solowa, nie są wyjątkowe. Generalnie, parametryzacja (czy to modelu Solowa, czy jego funkcji produkcji) wpływa na wszystkie analizy na podstawie których wnioskuje się o konwergencji. Nie tylko inne wartości parametrów (tj. stopa deprecjacji kapitału, czy elastyczności produkcji, której np. niższe wartości i brak zróżnicowania w regionach zwiększają tempo zbieżności, natomiast zróżnicowanie regionalne tego parametru i/lub wysokie jego wartości zmniejszają tempo konwergencji, a nawet powodują jej brak), lecz również inne definicje zmiennych (tj. produkcja, zatrudnienie, kapitał) mogą mieć wpływ na wyniki (na przykład w zależności od definicji kapitału regionalnego można otrzymać wniosek o występowaniu lub braku konwergencji). Zazwyczaj badacze nie przedstawiają szczegółowych wyjaśnień co do zastosowanej metody wyliczeń (zmiennych i parametrów), pomimo, że sposób ich wyznaczania wpływa na wielkość i dynamikę analizowanych zmiennych oraz, co za tym idzie, wnioski o konwergencji (pokazanie tych zależności w niniejszej pracy, pomimo, że było tylko etapem pośrednim przeprowadzanych badań, można uznać za wartościową analizę).

Parametryzacja nabiera szczególnego znaczenia w przypadku badań konwergencji technologicznej, której wyrazem w niniejszej pracy były badania oparte o łączną produktywność czynników produkcji - TFP. Wyznaczenie TFP jest zadaniem samym w sobie (w którym należy podjąć decyzje co do wartości wielu zmiennych i parametrów), a badania konwergencji tej zmiennej przeprowadzone na tak szeroką skalę (pod względem liczby użytych testów, jak i poziomów: zagregowanego i sektorowego; globalnego i lokalnego), jak w niniejszej pracy, nie są autorce znane. Uzyskano wynik, który ostrożnie można zinterpretować (ostrożność ta wynika właśnie $\mathrm{z}$ wpływu przyjętych w formule TFP wartości 
zmiennych i parametrów na wyniki o konwergencji) jako możliwość występowania konwergencji wojewódzkich $T F P$, co jest istotne przynajmniej z dwóch powodów. Po pierwsze dowodzi, że zaawansowanie technologiczne regionów nie ma tendencji do coraz większego zróżnicowania. Oznacza to, że postęp technologiczny, przynajmniej na terenie jednego państwa, jest możliwy do przemieszczania się i nie koncentruje się na jednym, nawet najlepiej rozwijającym się, obszarze. Choć należy przyznać, że dotyczy to głównie słabiej wyposażonych w czynniki produkcji regionów, bowiem za konwergencję TFP w Polsce odpowiedzialna jest konwergencja wśród województw o średnim poziomie zamożności i najuboższych. Zgodnie z teoriami przytoczonymi w rozdziale 1.1 tempo dyfuzji technologii zależy od wielkości luki technologicznej (w miarę zmniejszania się tej luki jej dalsze ograniczanie staje się coraz trudniejsze), co oznacza względną łatwość doganiania przez obszary o najniższym zaawansowaniu technologicznym. Uzyskane w niniejszej pracy wyniki w pełni potwierdzają tę tezę. Jak i tę, która mówi o tym, że w segmentach gospodarczych o niskim poziomie innowacyjności i zaawansowania konwergencja jest bardziej prawdopodobna - w praktyce średniozamożne, a w szczególności najuboższe województwa, w których zbieżność TFP była największa to jednocześnie te, których innowacyjność (zmierzona w podrozdziale 3.4.1 kryteriami trójsektorowej koncepcji rozwoju gospodarki) jest odpowiednio na średnim i najniższym poziomie.

Drugi powód doniosłości badań nad konwergencją TFP wynika z faktu, że, zgodnie z wskazaniami literaturowymi (por. Boldrin i Canova [2001, s. 211]), zróżnicowanie łącznej produktywności czynników produkcji jest jednym z trzech czynników wpływających na nierówności dochodowe. Jednakże, w przypadku badań polskiej gospodarki przeprowadzonych w tej książce, wbrew wskazówkom powyższych autorów, zróżnicowanie TFP jest zmienną, która wraz z poziomem zatrudnienia, wpływa na nierówności w wydajności pracy, zaś na nierówności dochodowe (mierzone PKB per capita) wpływa przede wszystkim rozwarstwienie udziału produkcji rolniczej i usługowej województw. Otrzymane wyniki pokazały zatem, że do konwergencji wydajności pracy przyczyniać się może konwergencja łącznej produktywności czynników produkcji oraz konwergencja zatrudnienia, zaś na dywergencję PKB per capita wpływa dywergencja produkcji w sektorze rolniczym i usługowym.

Badania sektorowe (w podziale na 4 sektory gospodarki: rolnictwo, przemysł, usługi rynkowe i usługi nierynkowe) potwierdziły wniosek znany z innych tego rodzaju badań światowych, a mianowicie, że występuje wyższy stopień konwergencji na zagregowanym poziomie niż w sektorach gospodarczych. Rzeczywiście, dla wydajności pracy w 4 sektorach gospodarczych nie można było stwierdzić istotnej konwergencji wydajności pracy. Konwergencją charakteryzowała się natomiast łączna produktywność czynników produkcji w sektorze rolni- 
czym, przemysłowym i usług nierynkowych, lecz nie w usługach rynkowych. Brak spójności w tym sektorze usług, jest szczególnie pejoratywny, bowiem to tutaj głównie zlokalizowane są usługi będące nośnikami gospodarki opartej na wiedzy (GOW). Pogłębione badania pokazały, że za wynik ten odpowiedzialna jest w dużej mierze coraz większa koncentracja usług rynkowych w województwie mazowieckim. To z kolei wiąże się z jego funkcjami metropolitarnymi, które polegają na pełnieniu działalności usługowej najwyższego rzędu, zwłaszcza o charakterze decyzyjnym, związanej z obecnością instytucji reprezentujących struktury kierowania, zarządzania i kontroli.

$\mathrm{Na}$ koniec podsumowania badań przeprowadzonych w części pierwszej książki - kilka uwag o charakterze metodologicznym. Przynajmniej od połowy lat 90. $\mathrm{XX}$ wieku badaczom wiadomo, że beta-konwergencja jest warunkiem koniecznym, lecz niewystarczającym do wystąpienia sigma-konwergencji, która z kolei jest wystarczającym lecz niekoniecznym warunkiem tej pierwszej. Prawidłowość ta została bardzo dobrze potwierdzona w niniejszej książce, w której wyniki badań na podstawie testów beta-konwergencji i sigma-konwergencji były często ze sobą sprzeczne. Ogólnie, można potwierdzić znany w literaturze fakt, że stosunkowo łatwo uzyskać beta-konwergencję i stosunkowo trudno sigmakonwergencję (dla której większość miar rozproszenia, czy koncentracji prowadziło do tego samego wniosku - a zatem zastosowana miara zróżnicowania nie miała znaczącego wpływu na uzyskiwane wyniki).

Generalnie trudno wskazać wyższość jednej metodologii weryfikowania konwergencji nad inną. $Z$ jednej strony w literaturze podkreśla się słabe własności estymatorów beta-konwergencji, prowadzące do zbyt optymistycznych szacunków tego zjawiska ${ }^{2}$, z drugiej, rzecznicy tej metody, jak Sala-i-Martin, argumentują, że w niektórych przypadkach koncepcja sigma-konwergencji jest po prostu bezużyteczna ${ }^{3}$. Należy po prostu uznać, że beta- i sigma-konwergencja, pomimo wspólnej nazwy, mierzą tak naprawdę dwa różne zjawiska - konwergencja typu sigma oznacza zmianę rozkładu cechy w czasie, zaś konwergencja typu beta - jej mobilność między regionami w ramach tego samego rozkładu. Pewnym kompromisem pomiędzy beta- i sigma-konwergencją może być konwergencja typu gamma, dla której zaproponowano pewne modyfikacje testów spotykanych w literaturze na użytek badań dla próby 16 województw. Ostatnie z zaproponowanych $\mathrm{w}$ rozdziale drugim podejść w weryfikacji hipotezy o kon-

\footnotetext{
${ }^{2}$ Choć wydaje się, że konsekwentne przeprowadzanie testów istotności dla estymatora parametru mierzącego konwergencję (dywergencję) wystarczyłoby do ograniczenia liczby pozytywnie przeprowadzanych weryfikacji hipotezy beta-konwergencji.

${ }^{3}$ Na dowód tego twierdzenia Sala-i-Martin [1996] przytacza przykład rankingu drużyn NBA, których zróżnicowanie jest stałe (czyli nie mają zastosowania testy sigma-konwergencji), natomiast to beta-konwergencja pozwala odpowiedzieć na pytanie, jak szybko słabe drużyny awansują w rankingach.
} 
wergencji - stochastycznej, dało wyniki tylko częściowo zbieżne z testami beta i sigma konwergencji. Generalnie, wobec różnych wniosków co do procesu konwergencji wyprowadzanych na podstawie testów różnego jej rodzaju (beta, sigma, gamma, stochastyczna) należy postulować, aby badania konwergencji opatrywać wyraźnym komentarzem, który rodzaj konwergencji był badany.

W drugiej części pracy celem była ocena wpływu funduszy unijnych na procesy konwergencji gospodarczej w Polsce. Zanim oceniono wpływ tej polityki na to zjawisko, pokazano jak historycznie kształtowały się procesy konwergencji na świecie i w Europie oraz wskazano na ogólną filozofię, genezę, historię i zasady finansowania polityki spójności (w rozdziale 4), wskazano na metody jej ewaluacji (w rozdziale 5) oraz zbadano, jaki wpływ ma ona na wzrost gospodarczy w Polsce i konwergencję gospodarczą województw (rozdział 6).

Generalnie, realizacja polityki spójności sprzyja szybszemu rozwojowi gospodarczemu całego kraju, co jest wynikiem faktu, że poszczególne województwa Polski notują przyspieszony wzrost po akcesji do Unii, a wyniki modeli służących ewaluacji polityki spójności pokazują, że część tych wzrostów jest rezultatem oddziaływania polityki spójności. Powstaje pytanie, czy siła i kierunek zmian, które dokonały się w województwach pod wpływem polityki spójności, sprzyjały konwergencji, czy przeciwnie - powodowały narastanie istniejących nierówności. Przeprowadzone w rozdziale 3. badania dla okresu 1995-2010 pokazały, że wśród polskich województw nie zachodzi proces konwergencji PKB per capita. Zawężenie czasu analizy do okresu realizacji polityki spójności w Polsce nie zmienia tego wniosku - w Polsce brak jest wewnętrznej konwergencji gospodarczej ${ }^{4}$.

Biorąc pod uwagę, że głównym celem realizowanej polityki spójności jest zmniejszanie nierówności gospodarczych (wśród regionów NUTS 2), wniosek o ich narastaniu mógłby stworzyć wątpliwość co do skuteczności prowadzonej polityki. Lecz pytanie o skuteczność polityki spójności powinno być w istocie pytaniem o to, czy dywergencja gospodarcza regionów w Polsce byłaby wyższa, gdyby polityka spójności nie była realizowana. Przeprowadzone badania pokazują, że polityka ta nie przyczyniła się w Polsce do odwrócenia negatywnego trendu wskazującego na dywergencję wojewódzkich PKB per capita, aczkolwiek nieznacznie osłabiła ten proces. Różnice w zmniejszeniu nasilenia zjawiska dywergencji są symboliczne, lecz szczególnie znamienne wobec wniosku o braku trafności (powiązaniu celów prowadzonej polityki z potrzebami regionów) programów regionalnych z okresu programowania 2004-2006 (limitacja danych

\footnotetext{
${ }^{4}$ Prognozy konwergencji (do roku 2020) bazujące na modelach zakładających pełne wykorzystanie środków unijnych przeznaczanych na realizację polityki spójności, również na nią nie wskazują. Z modeli tych wynika, że realizacja polityki spójności jedynie osłabi procesy dywergencyjne z jakimi mamy teraz do czynienia - por. Kusideł [2013c].
} 
z rachunków regionalnych spowodowała, że faktyczny wpływ polityki spójności mógł być empirycznie zbadany dla okresu oddziaływania NPR 2004-2006). Pomimo, że środki z NPR 2004-2006 nie trafiały w większym stopniu do regionów o najniższych wskaźnikach gospodarczych (co wynikało z przyjętego algorytmu ich przydzielania, polegającego głównie na kryterium wielkości populacji województw), to efektywność ich wykorzystania sprawiła, że proces dywergencji gospodarczej województw Polski uległ nieznacznemu osłabieniu.

Zupełnie inną kwestią jest bardzo ożywiona ostatnio dyskusja, czy wyrównawcze (lub redystrybucyjne) podejście w rozdziale środków jest właściwym sposobem ich podziału. $\mathrm{W}$ momencie kończenia tej pracy przewaga modelu polaryzacyjno-dyfuzyjnego w rozdziale środków z polityki spójności nad dotychczas stosowanym modelem wyrównawczym była właściwie przesądzona. Weryfikacja adekwatności takiego modelu nie wpisywała się w cele niniejszej pracy, niemniej stanowi osobny i ciekawy temat badawczy. 


\section{BIBLIOGRAFIA}

Amable B., M. Juillard, The historical Process of Convergence, January 2000.

Arellano M., S. Bond, Some tests of specification for panel data: Monte Carlo evidence and an apllication to employment equations, "Review of Economic Studies", 58, ss. 277-297, 1991.

Arellano M., Panel Data Econometrics, Oxford University Press, Oxford 2003.

Baltagi B.H., Econometric analysis of panel data, John Wiley \& Sons Ltd.,Chichester 1995.

Bamberger M., H. White, Using Strong Evaluation Designs in Developing Countries: Experience and Challenges, "Journal of MultiDisciplinary Evaluation", 4 (8), ss. 58-73, 2007.

Barro R., XX. Sala-i-Martin, World Real Interest Rates, NBER Chapters, in: NBER Macroeconomics Annual 1990, 5, National Bureau of Economic Research Inc, ss. 15-74, 1990.

Barro R., Makroekonomia, Polskie Wydawnictwo Ekonomiczne, Warszawa 1997.

Barro R., X.X. Sala-i-Martin, Convergence across states and regions, "Brookings Papers in Econommic Activity", 1, ss. 107-182, Washington 1991.

Barro R., X.X. Sala-i-Martin, Convergence, “Journal of Political Economy”, 100 (2), ss. 223-251, Chicago 1992.

Baumol W.J., Productivity Growth, Convergence and Welfare, "American Economic Review", 76, ss. 1072-1085, 1986.

Bernard A. B., C. I. Jones, Technology and Convergence, "Economic Journal”, 106 , ss. 1037 1044, Willey-Blackwell, 1996.

Bernard A.B., S.N. Durlauf, Interpreting Tests of the Convergence Hypothesis, "Journal of Econometrics", 71, Netherlands 1996.

Blundel R., S. Bond, GMM estimation with persistent panel data: an application to production functions, The Institute for Fiscal Studies, Working Paper Series No. W99/4, Paper presented at the Eighth International Conference on Panel Data Göteborg University, June 11-12, 1998.

Boldrin M., F. Canova, Inequality and convergence in Europe's regions: reconsidering European region al policies, "Economic Policy", 16 (32), Great Britain 2001.

Bondonio D., Impact identification strategies for evaluating business incentive programs, POLIS Working Papers, 129, Department of Public Policy and Public Choice - POLIS, 2009.

Bondonio D., R.T. Greenbaum, Revitalizing regional economies through enterprise support policies: An impact evaluation of multiple instruments, European Urban and Regional Studies, (Forthcoming).

Borys T., Pojęcie i struktura wewnętrzna koncepcji ekorozwoju, [w:] Wskaźniki ekorozwoju, T. Borys (red.), Wydawnictwo Ekonomia i Środowisko, Białystok 1999.

Borys T., B. Fiedor, Operacjonalizacja i pomiar kategorii zrównoważonego rozwoju - przyczynek do dyskusji [w:] Rachunki narodowe. Wybrane problemy i przyktady zastosowań, M. Plich (red.), Główny Urząd Statystyczny, Departament Rachunków Narodowych, Warszawa 2008.

Boyle G.E., T.G. McCarthy, A Simple Measure of $\beta$-convergence, "Oxford Bulletin of Economics and Statistics", 59 (2), 1997a. 
Boyle G.E., T.G. McCarthy, Simple Measures of Convergence in Per Capita GDP: A Note on Some Further International Evidence, Economics, Finance and Accounting Department Working Paper Series, Ireland 1997b.

Bradley J., G. Untiedt, Do economic models tell us anything useful about Cohesion Policy impacts? GEFRA Working Paper No 3, July 2007.

Bradley J., J. Zaleski, Wyniki modelowania wptywu funduszy strukturalnych i funduszu spójności na gospodarke polska przy zastosowaniu polskiej implementacji modelu HERMIN, Ministerstwo Gospodarki, Pracy i Polityki Społecznej, Warszawa 2002.

Bradley J., J. Zaleski, P. Tomaszewski, M. Zembaty, Ocena wptywu Narodowych Strategicznych Ram Odniesienia $i$ programów operacyjnych na polska gospodarke przy pomocy modelu makroekonomicznego HERMIN. Raport zbiorczy, EMDS-Dublin, WARR, Politechnika Wrocławska, Wrocław, grudzień 2007.

Brelik A., A. Grzelak, Ocena tendencji w ksztaltowaniu się dochodów gospodarstw rolnych w Polsce, "Journal of Agrobusiness and Rural Development", 2 (20), Poznań 2011.

Bryan L.,J. Kay, Dialogue: Can a Company Be Too Big? "The McKinsey Quarterly”, 4, 1999.

Bryson A., R. Dorsett, S. Purdon, The Use of Propensity Score Matching In the Evaluation of Active Labour Market Policies, Working Paper Number 4, 2002.

Bukowski M., I. Magda, Ł. Marć, J. Zawistowski, Źródła i perspektywy wzrostu produktywności w Polsce, Instytut Badań Strukturalnych, Warszawa 2006.

Bukowski M., D. Pelle, Wplyw realizacji inwestycji finansowanych z funduszy unijnych na kształtowanie się głównych wskaźników dokumentów strategicznych - Narodowego Planu Rozwoju $i$ Narodowej Strategii Spójności oraz innych wybranych wskaźników makroekonomicznych na poziomie krajowym $i$ wojewódzkimi, Instytut Badań Strukturalnych, Warszawa 2009.

Bukowski M., W.M. Saj, Wptyw funduszy unijnych na gospodarkę Polski w latach 2004-2020, Instytut Badań Strukturalnych, Warszawa 2008.

Bukowski K. K. Wierus, Wpływ realizacji polityki spójności na ksztaltowanie się głównych wskaźników dokumentów strategicznych - Narodowego Planu Rozwoju 2004-2006 i Narodowej Strategii Spójności 2007-2013 oraz innych wybranych wskaźników makroekonomicznych na poziomie krajowym i regionalnym. Raport pótroczny 2011. Część II: zestawienie wyników, Instytut Badań Strukturalnych, Warszawa 2011.

Bukowski M, K. Wierus, P. Kowal, Badanie wptywu realizacji inwestycji finansowanych z funduszy unijnych na kształtowanie się głównych wskaźników dokumentów strategicznych Narodowego Planu Rozwoju 2004-2006 i Narodowej Strategii Spójności 2007-2013 oraz innych wybranych wskaźników makroekonomicznych na poziomie krajowym i regionalnym, Instytut Badań Strukturalnych, Warszawa 2011.

Cappelen A., B. Tungodden, Responsibility and Reward, Public Finance Analysis, Mohr Siebeck, Tübingen, 59 (1), February 2002.

Carree M., L. Klomp, Testing the Convergence Hypothesis: a Comment, "Review of Economics and Statistics", 79, ss. 683-686, Cambridge 1997.

Ciołek D., Badanie konwergencji krajów Europy Środkowo-Wschodniej z wykorzystaniem danych panelowych, „Dynamiczne Modele Ekonometryczne”, Wydawnictwo Uniwersytetu Mikołaja Kopernika, Toruń 2003. 
Ciołek D., T. Brodzicki, Głębokie determinanty wzrostu gospodarczego - weryfikacja empiryczna z wykorzystaniem metod estymacji panelowych, „Analizy i Opracowania KEIE”, 1/2007, UG, Sopot 2007.

Cottrell A., R. Lucchetti, Gretl User's Guide, Gnu Regression, Econometrics and Time-series Library, January 2011.

Counterfactual Impact Evaluation of Cohesion Policy: Impact and Cost-Effectiveness of Investment Subsidies in Italy, Final Report to DG Regional Policy "Counterfactual Impact Evaluation of Cohesion Policy. Work Package 1: Examples from Enterprise Support", Contract nr 2010.CE.16.B.AT.042, June 2012.

Cuadrado-Roura, J.R., B. García-Greciano, J.L. Raymond, Regional convergence in productivity and productive structure: the Spanish case, "International Regional Science Review", 22, ss. 35-53, 1999.

Czyżewski A., S. Stępień, Wspólna polityka rolna UE po 2013 r. a interesy polskiego rolnictwa, "Ekonomista", 1, Warszawa 2011.

D’Alcantara, G., A. Italianer, A European Project for a Multinational Macrosectoral Model, Document MS 11, DG XII, Brussels: Commission of the European Communities 1982.

Dańska B., Przestrzenno-czasowe modelowanie zmian $w$ działalności produkcyjnej $w$ Polsce. Zastosowanie modeli panelowych, Absolwent, Łódź 2000.

Dańska-Borsiak B, Dynamiczne modele panelowe w badaniach ekonomicznych, Wydawnictwo Uniwersytetu Łódzkiego, Łódź 2011.

Davies S., F. Gross, D. Yuill, Wzrost czy równość. Mechanizmy i skutki alokacji funduszy w polityce regionalnej, Raport 07/5, "Raporty EoRPA 1/2008. Wzrost, czy równość?", Ministerstwo Rozwoju Regionalnego, Warszawa 2008.

Davies S. , M. Hallet, Interactions between national and regional development, [w:] HWWA Discussion Paper 207, Hamburg Institute of International Economics, Hamburg 2002.

De Long J.B., Productivity Growth, Convergence and Welfare: Comment, “American Economic Review",78, ss. 1138-1154, 1988.

Deaton A., Instruments of Development: Randomization in the Tropics, and the Search for the Elusive Keys to Economic Development, "NBER Working Paper", 14690, 2009.

Doyle E., E. O'Leary, The role of structural change in labour productivity convergence among European Union Countries: 1970-1990, "Journal of Economic Studies”, 26, ss. 106-120, 1999.

Drążkiewicz J., A. Gajdos, Z. Kołakowska, I. Kołodziej, E. Kusideł, M. Sochańska, Wpływ interwencji z funduszy strukturalnych UE na zatrudnienie, Ministerstwo Rozwoju Regionalnego, Warszawa 2007.

Drążkiewicz J., E. Kusideł, Ocena wptywu wsparcia z funduszy strukturalnych $w$ zakresie modernizacji i rozbudowy infrastruktury społecznej na realizację celów rozwojowych regionów, Ministerstwo Rozwoju Regionalnego, Warszawa 2009.

Drążkiewicz J., A. Gajdos, E. Kusideł, P. Penszko, The impact of Cohesion Policy on the level and quality of employment in Poland, Ministry of Regional Development, Warszawa 2010.

Drążkiewicz J., E. Kusideł, P. Penszko, The impact of Cohesion Policy on the level and quality of employment in countries of the Visegrad Group, Ministry of Regional Development, Warszawa 2011. 
Durlauf S.N., P.A. Johnson, Multiple Regimes and Cross Country Growth Behaviour, "Journal of Applied Econometrics", 10 (4), ss. 365-384, 1995.

Ederveen S., J. Gorter, Does European cohesion policy reduce regional disparities? An empirical analysis, CPB Discussion Paper 15, CPB Netherlands Bureau for Economic Policy Analysis, 2002.

Ederveen S., H. Groot, R. Nahuis, Fertile soil for structural funds? A panel data analysis of the conditional effectiveness of European cohesion policy, CPB Discussion Paper 10, CPB Netherlands Bureau for Economic Policy Analysis, 2002.

Ekiert K., Ewaluacja $w$ administracji publicznej. Funkcje standardy $i$ warunki stosowania, Rządowe Centrum Studiów Strategicznych, Warszawa 2004.

Ellison G., E. Glaeser, Geographic Concentration in U.S. Manufacturing Industries: A Dartboard Approach, "Journal of Political Economy", University of Chicago Press, 105(5), ss. 889-927, October 1997.

Encyklopedia PWN, Wydawnictwo Naukowe PWN, Warszawa 1999.

Enders W., Applied Econometric Time Series, Wiley\&Son, New York 1995.

Engle R.F., Granger C.W.J., Cointegration and error correction: representation, estimation and testing, "Econometrica", 55, ss. 251-276, 1987.

Europejska polityka spójności w Polsce 2009, dokumenty DCRegio, Komisja Europejska, Bruksela 2009.

Evaluating Socio Economic Development, SOURCEBOOK 2: Methods \& Techniques Econometric models. Final Materials, European Commision, December 2003.

Ewaluacja programów wydatków Unii Europejskiej. Przewodnik. XIX/02 - Synthèse budgétaire et evaluation, Dyrekcja Generalna XIX - Budżet, Komisja Europejska, styczeń 1997.

Ferry M., Kierunki rozwoju polityki regionalnej w Polsce, Raport 08/2, [w:] Raporty EoRPA 2/2009. Rozwój regionalny w Europie: spójność terytorialna i przeglad budżetu UE, Ministerstwo Rozwoju Regionalnego, Warszawa 2009.

Ferry M., Rozwój polityki regionalnej w Polsce 2008-2009, Raport 09/3, [w:] Raporty EoRPA 3/2010. Rozwój regionalny $w$ Europie: polityka regionalna $w$ kontekście kryzysu $i$ nowych wyzwań, Ministerstwo Rozwoju Regionalnego, Warszawa 2010.

Fiedor B., K. Kociszewski (red.), Ekonomia rozwoju, Wydawnictwo Uniwersytetu Ekonomicznego we Wrocławiu, Wrocław 2010.

Florczak W., Produktywność czynników wzrostu PKB, „Wiadomości statystyczne”, 2, Warszawa 2011.

Friedman M., Do old fallacies ever die?, "Journal of Economic Literature", t. 30, ss. 2129-2132, 1992.

Gáková Z., D. Grigonyt, P. Monfort, The COHESION system of HERMIN country and regional models: description and operating manual, Report submitted under contract No. 2005CE160AT027 to DG Regional Policy, April 2007.

Gakova Z. D. Grigonyte, P. Monford, A Cross-Country Impact Assessment of EU Cohesion Policy. Applying the Cohesion System of HERMIN models. A series of short papers on regional research indicators produced by the Directorate General for Regional Policy, European Union Regional Policy, 01/2009, 2009. 
Galor O., Convergence? Inferences from Theoretical Models, "Economic Journal”, 106, ss.10561070, 1996.

Gawlikowska-Hueckel K., A. Zielińska-Głębocka, Integracja europejska. Od jednego rynku do unii walutowej, C.H.Beck, Warszawa 2004.

Geodecki T., Procesy konwergencji $i$ polaryzaji $w$ regionach Unii Europejskiej, Zeszyty Naukowe Akademii Ekonomicznej w Krakowie, 714 , Kraków 2006.

Glińska-Neweś A., Kulturowe uwarunkowania zarządzania wiedza w przedsiębiorstwie, TNOiK, Torun 2007.

Głuszek E., Zarządzanie zasobami niematerialnymi, Wyd.AE im.O.Langego, Wrocław 2004.

Gorzelak G., Poland's regional policy and disparities in the Polish Space, „Studia Regionalne i Lokalne", Tom I wyd. spec, Warszawa 2006.

Gorzelak G., Fakty i mity rozwoju regionalnego, „Zarządzanie Publiczne”, 4(6)/2008, Warszawa 2008.

Grabek G., B. Kłos, G. Utzig-Lenarczyk, SOE-PL - model DSGE małej otwartej gospodarki estymowany na danych polskich, Metodologia, specyfikacja, wyniki estymacji i pierwsze zastosowania, „Materiały i Studia NBP”, 217, Warszawa 2007.

Gradziewicz M., M. Kolasa, Szacowanie luki popytowej dla gospodarki polskiej przy wykorzystaniu metody VECM, „Bank i Kredyt”, luty 2004.

Grauwe P.D., DSGE Modeling. Where agents are imperfectly informed ,Working Papers Series, 897, European Central Bank, 2008.

Gruszczyński M., Ekonometria, PWN, Warszawa 2006.

Harris R.G., The Knowledge-Based Economy: Intellectual Origins and New Economic Perspectives, "International Journal of Management Reviews", 3, 2001.

Ignaszak M., O bogactwie narodów, „Trend - miesięcznik o sztuce inwestowania”, Fundacja Akademickie Inkubatory Przedsiębiorczości przy SGH w Warszawie, Warszawa, grudzień 2011.

Indicative guidelines on evaluation methods: Ex ante evaluation, "European Commission Directorate General Regional Development, The New Programming Period 2007-2013", European Commision, Working Document No. 1, August 2006.

Islam I., What Have We Learnt From Convergence Debate, "Journal of Economic Surveys", ss.309-362, 2003.

Jakubiak M. (red.), Ocena zbieżności rozwoju społeczno-gospodarczego Polski z Uniq Europejska, Raport CASE - Centrum Analiz Społeczno-Ekonomicznych, Warszawa 2006.

Johansen S., Statistical Analysis of Cointegration Vectors, "Journal of Economic Dynamics and Control", 12, ss. 231-254, 1988.

Johansen S., Likelihood-Based Inference in Cointegrated Vector Autoregressive Models, Oxford University Press, New York 1995.

Kaczmarczyk P., J. Tyrowicz, Wspótczesne procesy migracyjne w Polsce a aktywność organizacji pozarzadowych $w$ obszarach powiazanych z rynkiem pracy, Portal Instytucji Rynku Pracy, Warszawa 2010. 
Kaczmarczyk P., Kryzys a decyzje migracyjne Polaków, „Biuletyn FISE”, 3, 2010.

Kaczor T., Możliwości wykorzystania transferów z budżetu Unii Europejskiej. Analiza przy pomocy modelu równowagi ogólnej, Rozprawa doktorska, maszynopis, Warszawa 2005.

Kaczor T., J. Mackiewicz-Łyziak, M. Michniewicz, R. Socha, K. Soszyński, Wptyw realizacji polityki spójności na kształtowanie się głównych wskaźników dokumentów strategicznych Narodowego Planu Rozwoju 2004 - 2006 i Narodowej Strategii Spójności 2007 - 2013 oraz innych wybranych wskaźników makroekonomicznych na poziomie krajowym i regionalnym, Ministerstwo Rozwoju Regionalnego, IBnGR-Prevision, Gdańsk-Warszawa, czerwiec 2010.

Kaczor T., R. Socha, Badanie wptywu Narodowego Planu Rozwoju 2004-2006 i Narodowych Strategicznych Ram Odniesienia 2007-2013 na wybrane wskaźniki dokumentów strategicznych (za pomoca modelu MaMoR2), Instytut Badań nad Gospodarką Rynkową, Warszawa, kwiecień 2008.

Kaczor T, M. Mackiewicz-Łyziak, M. Michniewicz, Wpływ realizacji polityki spójności na ksztaltowanie się głównych wskaźników dokumentów strategicznych NPR 2004-2006 i NSS 20072013. Tom 2. Wskaźniki, Prevision-IBnGR, Warszawa, listopad 2011.

Khan M., Investment in Knowledge, [w:] "Special Issue on New Science and Technology Indicators”, STI Review, OECD Science, Technology and Industry Scoreboard 2005, Paris 2005.

Khandker S.R., G. B. Koolwal, H. A. Samad, Handbook on Impact Evaluation. Quantitative methods and practices, The World Bank, 2010.

Klimowicz M., Fundusze strukturalne oraz Fundusz Spójności w państwach Europy Środkowej $i$ Wschodniej, CeDeWu, Warszawa 2010.

Knosala R., Komputerowo zintegrowane zarządzanie, WNT, Warszawa 2004.

Kolipiński B., Ład przestrzenny w Polsce - stan i problemy. Ekspertyza, Ministerstwo Rozwoju Regionalnego, Warszawa 2011.

Kolko J., Can I get some service here? Information technology service industries, and the future of cities, Public Policy Institute of California, San Francisco, November 1999.

Komunikat Komisji do Parlamentu Europejskiego, Rady, Europejskiego Komitetu EkonomicznoSpołecznego, Komitetu Regionów oraz Europejskiego Banku Inwestycyjnego, COM (2010) 642/3, Bruksela 2010.

Kopczewska K., T. Kopczewski, P. Wójcik, Metody ilościowe w R. Aplikacje ekonomiczne i finansowe, CeDeWu, Warszawa 2009.

Kopycińska D. (red.), Teoretyczne aspekty gospodarowania, Katedra Mikroekonomii Uniwersytetu Szczecińskiego, Szczecin 2005.

Korczyn A, P. Sasin, Polska Klasyfikacja Działalności, Sigma Wydawnictwo, Skierniewice 2005.

Korol J., Wskaźniki zrównoważonego rozwoju $w$ modelowaniu procesów regionalnych, Wydawnictwo Adam Marszałek, Toruń 2007.

Kostro K., Kapitat spoteczny w teorii ekonomicznej, „Gospodarka Narodowa”, Warszawa 2005.

Kotowska E., (red.), Rynek pracy i wykluczenie społeczne $w$ kontekście percepcji Polaków diagnoza społeczna 2009, Centrum Rozwoju Zasobów Ludzkich, Warszawa 2009. 
Krugman P., Increasing Returns and Economic Geography, "Journal of Political Economy”, 99 (3), 1991.

Kudełko J., A. Prusek, K. Zieliński, Europejska polityka spójności oraz jej efekty w Polsce, Wydawnictwo Uniwersytetu Ekonomicznego w Krakowie, Kraków 2011.

Kumor P., Wspótzależność nierówności płac ze wzrostem gospodarczym w Polsce, „Wiadomości Statystyczne", 7/2009, ss. 10-28, Warszawa 2009.

Kurach J., M. Słodowa-Hełpa, Fundusze Unii Europejskiej jako instrumenty spójności społecznogospodarczej regionów [w:] „Gospodarka Polski po akcesji do Unii Europejskiej. Wymiar ekonomiczno-społeczny", W. Czternasty (red.), Wydawnictwo Uniwersytetu Ekonomicznego w Poznaniu, Poznań 2011.

Kusideł E, Modele wektorowo - autoregresyjne VAR. Metodologia i zastosowania, Absolwent, Łódź 2000.

Kusideł E., Wplyw realizacji polityki spójności na ksztaltowanie się głównych wskaźników dokumentów strategicznych - Narodowego Planu Rozwoju 2004-2006 i Narodowej Strategii Spójności 2007-2013 oraz innych wybranych wskaźników makroekonomicznych na poziomie krajowym $i$ regionalnym, ekspertyzy dla Ministerstwa Rozwoju Regionalnego dot. oceny raportów metodologicznych, cząstkowych i końcowych z badań ewaluacyjnych o ww. tytule wykonywanych na podstawie modeli: Hermin, EuImpactMod, MaMoR, maszynopisy, Warszawa 2009-2010.

Kusideł E., Metody oceny wplywu funduszy strukturalnych na zatrudnienie, "Acta Universitatis Lodziensis. Folia Oeconomica", 209, Wydawnictwo Uniwersytetu Łódzkiego, ss.279-286, Łódź 2007.

Kusideł E., Wplyw metropolii łódzkiej na rozwój społeczno-gospodarczy regionu, "Acta Universitas Lodziensis. Folia Oeconomica”, 246, ss. 159-168, Łódź 2010a.

Kusideł E., Convergence on local labour market, "Acta Universitas Lodziensis. Folia Oeconomica”, 252, Wydawnictwo Uniwersytetu Łódzkiego, ss. 61-68, Łódź 2010 b.

Kusideł E., E. Modranka, Zmiany na polskim rynku pracy po akcesji do Unii Europejskiej i przyszłe kierunki rozwoju wynikające $z$ dokumentów strategicznych oraz zmian demograficznych, "Acta Universitas Lodziensis. Folia Oeconomica", Wydawnictwo Uniwersytetu Łódzkiego, ss. 159-179, Łódź 2011.

Kusideł E., The Impact of the Cohesion Policy on Poland's Economic Development, [w:] "Statistical Methods in Analyses of Economic Phenomena under Integration and Globalization", P.Cmela, K. Kruszyński (red.), Statistical Office in Lodz, ss.191-208, Warsaw 2012a.

Kusideł E., Wpływ polityki spójności na konwergencję wewnętrzna w Polsce, „Prace Naukowe Uniwersytetu Ekonomicznego we Wrocławiu", ss.246-256, Wrocław 2012 b.

Kusideł E, K. Lewandowska-Gwarda, Projekcje PKB per capita (wg PPS) na poziomie województw (NUTS-2) oraz wybranych podregionów (NUTS-3) do 2020 roku wraz z analiza konsekwencji ewentualnych zmian klasyfikacji NUTS dla polityki spójności po 2020 roku, ekspertyza dla Ministerstwa Rozwoju Regionalnego, Warszawa 2012.

Kusideł E., J. Górniak, Transport Availability vs. Development of Poland's Regions, "Comparative Economic Research. Central and Eastern Europe”, 4/2012, ss. 105-116, Łódź 2012.

Kusideł E., Convergence of Regional Human Development Indexes in Poland, "Comparative Economic Research. Central and Eastern Europe”, 1/2013, ss. 87-102, Łódź $2013 a$. 
Kusideł E., Social convergence in Poland, "Acta Universitas Lodziensis. Folia Oeconomica”, Łódź 2013b.

Kusideł E., Prognozy konwergencji gospodarczej województw Polski do roku 2020, „Prace Naukowe Uniwersytetu Ekonomicznego we Wrocławiu", Wrocław 2013c.

Kuznetz S., Economic growth and income inequality, "The American Economic Review", 45 (1), ss. 1-28, 1955.

Kwiatkowski E., Teoria trzech sektorów gospodarki: prezentacja i próba oceny, PWN, Warszawa 1980.

Laskowska I., Zdrowie $i$ nierówności $w$ zdrowiu-determinanty $i$ implikacje ekonomicznospołeczne, Wydawnictwo Uniwersytetu Łódzkiego, Łódź 2012.

Le Gallo J., S. Dall'erba, Spatial and sectoral productivity convergence between European regions, 1975-2000, "Paper in Regional Science", 87 (4), ss. 505-525, November 2008.

Lichtenberg F., Testing the Convergence Hypothesis, "This REVIEW", 76, ss. 576-579, 1994.

Lucas R., On the mechanizm of economic development, "Journal of Monetary Economics", 22, ss. 3-42, Elsevier, 1988.

Lucas R., Econometric Policy Evaluation: A Critique, Carnegie-Rochester Conference Series on Public Policy, Elsevier, 1976.

Łastawski K., Historia integracji europejskiej, Wydawnictwo Adam Marszałek, Toruń 2006.

Łaźniewska E., T. Górecki, R. Chmielewski, Konwergencja regionalna, Wydawnictwo Uniwersytetu Ekonomicznego w Poznaniu, Poznań 2011.

Łuniewska M., W. Tarczyński, Metody wielowymiarowej analizy porównawczej na rynku kapitałowym, Wydawnictwo Naukowe PWN, Warszawa 2006.

Maddison A., The world economy. A millennial perspective, OECD Publishing, 2001.

Majsterek M., Wielowymiarowa analiza kointegracyjna w ekonomii, Wydawnictwo Uniwersytetu Łódzkiego, Łódź 2008.

Malaga K, P. Kliber, Konwergencja i nierówności regionalne $w$ Polsce w świetle neoklasycznych modeli wzrostu, Wydawnictwo Akademii Ekonomicznej w Poznaniu, Poznań 2007.

Malinowska-Misiąg E., W. Misiąg, M. Tomalak, Przestrzenne zróżnicowanie dochodów $i$ wydatków publicznych w Polsce w latach 2004-2005, Ministerstwo Rozwoju Regionalnego, Warszawa 2008.

Mankiw N.G., D. Romer, D.N. Weil, A Contribution to the Empirics of Economic Growth, "Quarterly Journal of Economics", 107, ss. 407-437, 1992.

Manuel A., Modelling Optimal Instrumental Variables For Dynamic Panel Data Models, Working Papers wp2003_0310, CEMFI, 2003.

Manuel A., Discrete choices with panel data, "Investigaciones Economicas", Fundación SEPI, 27(3), ss. 423-458, September 2001.

Martin C., I. Sanz, Real Convergence and European Integration: The Experience of the Less Development UE Members, "Springer Empirika”, 3, ss.205-236, September 2003.

Mazur S. (red.), Ewaluacja funduszy strukturalnych - perspektywa regionalna, Uniwersytet Ekonomiczny, Małopolska Szkoła Administracji Publicznej, Kraków 2007. 
Monfort P., Convergence of EU Regions. Measures and evolution, European Union EU Regional Policy Working Papers, 01/2008, 2008.

Myrdal G., An American Dilemma, The Negro Problem and Modern Democracy, New York, Harper, New York 1944.

Narodowe Strategiczne Ramy Odniesienia 2007-2013 wspierajace wzrost gospodarczy i zatrudnienie, Ministerstwo Rozwoju Regionalnego, Warszawa, listopad 2006.

Narodowy Plan Rozwoju 2004-2006, dokument przyjęty przez Radę Ministrów w dniu 14 stycznia 2003 r., Warszawa, styczeń 2003.

Nowak K., Problem bezrobocia strukturalnego: czego uczy nas teoria poszukiwań $i$ dopasowań na rynku pracy?, „Ekonomista”, 1/2011, Wydawnictwo Key Text sp.z o.o., Warszawa 2011.

Nowak W., Koncepcje konwergencji w teorii wzrostu gospodarczego, Zeszyty Uniwersytetu Rzeszowskiego. Katedra Ekonomii, 8, Rzeszów 2006.

Ocena systemu realizacji polityki spójności w Polsce w ramach perspektywy 2004-2006, Ego s.c., Warszawa 2010.

Ocena instrumentów wsparcia bezpośredniego przedsiębiorstw, PARP, Warszawa 2010.

Olejniczak K., Rola ewaluacji w krajowych politykach publicznych-analiza systemowa lata 19992010, [w:] „Ewaluacja w strategicznym zarządzaniu publicznym”, A. Haber (red.), Polska Agencja Rozwoju Przedsiębiorczości, Warszawa 2010.

Olejniczak K., M. Kozak, B. Ledzion, (red.), Teoria $i$ praktyka ewaluacji interwencji publicznych: podręcznik akademicki, Wydawnictwo Akademickie i Profesjonalne Akademia Leona Koźmińskiego, Warszawa 2008.

Orłowski W.M., Koszty i korzyści z członkostwa w Unii Europejskiej, CASE, Warszawa 2000.

Osińska M., Ekonometria współczesna, Wydawnictwo Uniwersytetu Mikołaja Kopernika, Toruń 2007.

Papadas C. T., S. Efstratoglou, Estimation of Regional Convergence equation using artificial neutral networks with cross-section data, "New Economic Papers", New York 2004.

Parente, S. L., E. C. Prescott, Monopoly Rights: A Barrier to Riches, “American Economic Review", 89, ss. 1216-33, 1999.

Parente, S. L., E. C. Prescott, A Unified Theory of the Evolution of International Income Levels, National Bank of Poland, Warszawa 2003.

Pawłowski J., Diagnoza potencjału innowacyjności i konkurencyjności przedsiębiorstwa, „Przegląd Organizacji”, 5, Warszawa 2005.

Perez J., M. Dones, C. Liano, An interregional impact analysis of the EU structural funds in Spain (1995-1999), "Paper of Regional Science", 3 (08), ss. 509-529, 2009.

Perło D., Regionalny model Hermin - przykład województwa podlaskiego, [w:] „Rachunki narodowe. Wybrane problemy i przykłady zastosowań”, M. Plich (red.), Główny Urząd Statystyczny. Departament Rachunków Narodowych, Łódź 2008.

Patton M.Q., Qualitive Evaluation and Research Method, second edition, Stage Publications, London 1990. 
Philippe M., Convergence of EU regions. Measures and evolution, "Working papers of Directorate-General for Regional Policy", 01/2008, Brussels 2008.

$P K B \quad$ na poziomie regionalnym (http://epp.eurostat.ec.europa.eu/statistics_explained/index.php/GDP_at_regional_level/pl\#Parytet_si.C5.82y_ nabywczej_i_mi.C4.99dzynarodowe_por.C3.B3wnania_ilo.C5.9Bciowe, 05.08.2012).

Polska 2010, Raport o rynku pracy oraz zabezpieczeniu spotecznym, Ministerstwo Pracy i Polityki Społecznej, Warszawa 2010.

Prescott E., Needed: A Theory of Total Factor Productivity, International Economic Review, Department of Economics, University of Pennsylvania and Osaka University Institute of Social and Economic Research Association, 39(3), ss. 525-551, August 1998.

Prochowicz R., J. Śleszyński, Wskaźnik trwałego dobrobytu ekonomicznego dla Polski w okresie 1990-2004, [w:] „Rachunki narodowe. Wybrane problemy i przykłady zastosowan”, GUS-UŁ, Warszawa 2008.

Produkt Krajowy Brutto - Rachunki Regionalne [wydania z różnych lat], Główny Urząd Statystyczny, Warszawa.

Prognoza Ludności Polski na lata 2008-2035, GUS, Warszawa 2008.

Próchniak M., Realna konwergencja w krajach Unii Europejskiej. Próba szacunków funkcji produkcji, [w:] „Zmiany aktywności gospodarczej w świetle wyników badań koniunktury”, Prace i materiały Instytutu Rozwoju Gospodarczego SGH, 87, Warszawa 2011.

Próchniak M., R. Rapacki, Konwergencja typu beta $(\beta)$ i sigma $(\sigma)$ w krajach transformacji w latach 1990-2005 [w:] "Wzrost gospodarczy w krajach transformacji: konwergencja czy dywergencja?", R. Rapacki (red.), Polskie Wydawnictwo Ekonomiczne, ss. 148-149, Warszawa 2009.

Próchniak M., Z. Matkowski, Zbieżność rozwoju gospodarczego w krajach Europy ŚrodkowoWschodniej w stosunku do Unii Europejskiej, „Ekonomista”, ss. 293-320, Warszawa 2005.

Puga D., European regional policies in light of recent location theories, "Journal of Economic Geography”, Oxford University Press, 2(4), ss. 373-406, October 2002.

Pylak K., Podręcznik ewaluacji projektów infrastrukturalnych, Ministerstwo Rozwoju Regionalnego, Warszawa 2009.

Quah D., Galton's Fallacy and Tests of the Convergence Hypothesis, December 1993.

Raport Polska 2030, Kancelaria Prezesa Rady Ministrów, Warszawa 2009.

Review of Methodologies Applied for the Assessment of Employment and Social Impacts, "IZA Research Report", 28, 2010.

Rey S.J., B. Dev, $\sigma$-convergence in the presence of spatial effects, "Papers in Regional Science", 85, ss. 217-234, June 2006.

Rodrigues-Pose A., U. Fratesi, Między rozwojem a polityka spoleczna: oddzialywanie europejskich funduszy strukturalnych $w$ regionach celu 1, „Studia Regionalne i Lokalne”, 3(17)/2004, ss. 6-32, Warszawa 2004.

Roeger M.W., J. Veld, QUEST III: an estimated DSGE model of the euro area with fiscal and monetary policy, European Economy - Economic Papers, 335, Directorate General Economic and Monetary Affairs, European Commission, 2008. 
Roeske-Słomka I., Statystyka opisowa, Wydawnictwo Uniwersytetu Ekonomicznego w Poznaniu, Poznań 2010.

Rozporzadzenie Rady Unii Europejskiej z dn. 21.06.1999 r., wprowadzające ogólne przepisy dotyczące funduszy strukturalnych, Bruksela 1999.

Sala-i-Martin X.X., Regional cohesion: Evidence and theories of regional growth and convergence, "European Economic Review", 4, 1996.

Scriven M., A Summative Evaluation of RCT Methodology: An Alternative Approach to Causal Research, "Journal of MultiDisciplinary Evaluation", 5 (9), 2008.

Shankar R., A. Shah, Bridging the economic divide within nations: a scorecard on the performance of regional development policies in reducing regional income disparities, "World Development”, 31( 8), Pergamon, ss. 1421-1441, Great Britain 2003.

Stownik języka polskiego, M. Szymczak (red.), PWN, Warszawa 1978.

Stownik wyrazów obcych, J. Tokarski (red.), PWN, Warszawa 1980.

Smuga T. ,(kier. proj.), Ocena szacunkowa Narodowych Strategicznych Ram Odniesienia 20072013. Raport końcowy, Instytut Koniunktur i Cen Handlu Zagranicznego, Warszawa, listopad 2006.

Solow R. M., A Contribution to the Theory of Economic Growth, "Quarterly Journal of Economics", 70, ss. 65-94, 1956.

Spójność wewnętrzna a konkurencyjność regionu łódzkiego. Diagnoza strategiczna, raport z badania zamawianego przez Urząd Marszałkowski Województwa Łódzkiego, Instytut Badań Strukturalnych, Łódź 2009.

Stobińska K., Zarządzanie wiedza. Wyzwania dla zarzadzania zasobami ludzkimi, „Organizacja i Kierowanie", 1, Warszawa 2004.

Strahl D., Modelowanie ekonometryczne z Excelem, Wydawnictwo Akademii Ekonomicznej im. O. Langego we Wrocławiu, Wrocław 2002.

Strategia Rozwoju Kraju 2007-2015, Ministerstwo Rozwoju Regionalnego, Warszawa, listopad 2006.

Suchecka J., Metody statystyczne. Zarys teorii, przyktady i zadania, Politechnika Częstochowska, Częstochowa 2002.

Suchecki B. (red.), Ekonometria przestrzenna, Metody i modele analizy danych przestrzennych, Wydawnictwo C. H. Beck, Warszawa 2010.

Swan T.W., Economic Growth and Capital Accumulation, "Economic Record", 32, ss. 334-361, Wiley\&Blackwell, November 1956.

Sztumski W., Idea zrównoważonego rozwoju a możliwości jej urzeczywistnienia, „Problemy Ekorozwoju", 2, ss. 73-76, Warszawa 2006.

Świeczewska D., Łączna produktywność czynników produkcji. Ucieleśniony kapital wiedzy, [w:] „Gospodarka oparta na wiedzy”, W. Welfe (red.), ss. 58-111, PWE, Warszawa 2007.

Świeczewska D., Innovative TFP Growth Factors in the Chosen E, [w:] „Statistical Methods in Analyses of Economic Phenomena under Integration and Globalization", P. Cmela, K. Kruszyński (red.), ss. 109-120, Statistical Office in Lodz, Warszawa 2012. 
Tarka D., Taksonomiczna analiza województw - aspekt ekologiczny [w:] „Rozwój regionalny podstawowe cele i wyzwania", Andrzej F. Bocian (red.), Wydawnictwo Uniwersytetu w Białymstoku, Białystok 2007.

Tkaczyński J. W., R. Willa, M. Świstak, Fundusze Unii Europejskiej 2007-2013. Cele Działania - Środki, Wydawnictwo Uniwersytetu Jagiellońskiego, Kraków 2008.

Toffler A., Trzecia fala, PIW, Warszawa 1997.

Traktat ustanawiający Europejska Wspólnotę Węgla i Stali, EWWiS, Paris 1951.

Traktat ustanawiajacy Europejska Wspólnotę Gospodarczą, traktat EWG, Rzym 1957 (tekst pierwotny, przed konsolidacją).

Traktat ustanawiający Europejską Wspólnotę Energii Atomowej (Euratom), Rzym 1957.

Traktat o Unii Europejskiej (Traktat z Maastricht), Maastricht 1992.

Tyszka T.(red), Psychologia ekonomiczna, Gdańskie Wydawnictwo Psychologiczne, Sopot 2004.

Udry C., Gender, Agricultural Production and the Theory of the Household, "The Journal of Political Economy", 104 (5), ss. 1010-1046, 1996.

Uniwersalny Stownik Języka Polskiego PWN, Dubisz S. (red.), PWN, Warszawa 2008.

Ustawa o podatku dochodowym od osób fizycznych, Dz.U., 2012 poz. 361.

Ustawa o podatku dochodowym od osób prawnych, Dz.U., 2011, 74, poz. 397.

Ustawa z dnia 27 kwietnia 2001 r., Prawo ochrony środowiska, Dz. U. ,62, poz. 627, Warszawa 2001.

Vandenberghe V., S. Robin, Evaluating the effectiveness of private education cross countries: a comparison of methods, "Labour Economics", 11, 2004.

Varga J., J. Veld, The potential impact of EU cohesion policy spending in the 2007-13 programming period. A model-based analysis, "European Economy", September 2010.

Wallush J., Ewolucja nowokeynesowskiej krzywej Philipsa, „Ekonomista”, 5/2000, Wydawnictwo Key Text, Warszawa 2008.

Welfe W., Empiryczne modele wzrostu gospodarczego, „Ekonomista”, 4/2000, ss. 483-499, Warszawa 2000.

Welfe W. (red.), Ekonometryczny model wzrostu gospodarczego, Wydawnictwo Uniwersytetu Łódzkiego, Łódź 2001.

Welfe W. (red.), Makroekonometryczny model gospodarki opartej na wiedzy, „Folia Oeconomica”, 229, Łódź 2009.

Welfe W, Makroekonometryczny model W8-P gospodarki polskiej - podstawowe równania strukturalne modelu, materiały przygotowane w ramach projektu KBN: PCZ 006-23 pt. „System prognozowania popytu na pracę", Łódź 2004.

Welfe W, Ekonometryczne modele zatrudnienia, [w:] „Przestrzenno-czasowe modelowanie i prognozowanie zjawisk gospodarczych", A. Zeliaś (red.), Wydawnictwo Akademii Ekonomicznej w Krakowie, Kraków 2005.

Welfe W., Wyzwania dla makromodelowania wynikajace z przechodzenia do gospodarki opartej na wiedzy, [w:] „Unia Europejska w kontekście strategii lizbońskiej oraz gospodarki 
i społeczeństwa wiedzy w Polsce”, E. Okoń-Horodyńska, K. Piech (red.), Instytut Wiedzy i Innowacji, Warszawa 2006.

Wielkość i struktura wydatków poniesionych w ramach Narodowego Planu Rozwoju w okresie 2004-2009, Ministerstwo Rozwoju Regionalnego, Warszawa 2010.

Williamson J.G., Regional inequality and process of national development: a description of the patterns", "Economic Development and Cultural Change", XIII (4, Part II), ss. 2-84. Chicago 1965.

Wolszczak-Derlacz J., Wspólna Europa, różne ceny - analiza procesów konwergencji, Wydawnictwo CeDeWu, Warszawa 2007.

Wong Wei-Kang, OECD Convergence: A Sectoral Decomposition Exercise, 2006.

Wplyw funduszy europejskich na gospodarkę polskich regionów $i$ konwergencje polskich regionów z krajami UE. Raport 2010, Ministerstwo Rozwoju Regionalnego, Warszawa 2010.

Wytyczne dotyczące stosowania jednolitych wskaźników makroekonomicznych będących podstawa oszacowania skutków finansowych projektowanych ustaw. Aktualizacja - grudzień 2011 r., Ministerstwo Finansów, Warszawa, grudzień 2011.

Yuill D., M. Ferry, Przeglad, zmiany, reformy. Najnowsze zmiany w polityce regionalnej $w$ UE $i$ Norwegii, Raport 07/1, [w:] „Raporty EoRPA 1/2008: Wzrost czy równość?”, Ministerstwo Rozwoju Regionalnego, Warszawa 2008.

Zaldivar M. G., Per capita output convergence: the Dickey-Fuller test under the simultaneous presence of stochastic and deterministic trends, Universidad de Guanajuato, Meksyk 2010.

Zaleski J., P. Tomaszewski, M. Zembaty, A. Wojtasiak, J. Bradley, Raport nr 1. Modyfikacja i uaktualnienie wersji modelu HERMIN dla Polski, Wrocław, wrzesień 2004.

Zaleski J., P. Tomaszewski, A. Wojtasiak, J. Bradley, Raport 4. Wstepny model dla polskich regionów. Studium przypadku na przykładzie województwa dolnoślaskiego, WARR, Wrocław, październik 2004.

Zaleski J., P. Tomaszewski, M. Zembaty, A. Wojtasiak, J. Bradley, Raport. Regionalny model HERMIN gospodarki województwa łódzkiego. Podręcznik, Wrocław, listopad 2005.

Zaleski J., P. Tomaszewski, M. Zembaty, A. Wojtasik, J. Bradley, Raport. Baza danych 16 modeli regionalnych dla polskich województw, Wrocław, listopad 2005.

Zaleski J., P. Tomaszewski, M. Zembaty, J. Bradley, Ocena makroekonomicznego wptywu realizacji Narodowego Planu Rozwoju na lata 2004-2006 oraz Narodowych Strategicznych Ram Odniesienia na lata 2007-2013 przy użyciu modelu Hermin dla polskiej gospodarki, Wrocławska Agencja Rozwoju Regionalnego-Economic Modeling and Development Strategies in Dublin, Politechnika Wrocławska, Dublin-Wrocław, lipiec 2007.

Zaleski J, J. Kudełko, Z. Mogiła, A. Poproch, P. Tomaszewski, M. Zembaty, Oszacowanie wplywu realizacji Narodowego Planu Rozwoju 2004-2006 (NPR) i Narodowych Strategicznych Ram Odniesienia/Narodowej Strategii Spójności 2007-2013 (NSRO/NSS) na wybrane wskaźniki makroekonomiczne na poziomie regionalnym do roku 2020 przy użyciu modeli regionalnych HERMIN. Raport końcowy, Wrocławska Agencja Rozwoju Regionalnego, Wrocław, czerwiec 2011.

Zeliaś A., Metody statystyczne, Polskie Wydawnictwo Ekonomiczne, Warszawa 2000. 
Zielińska-Głębocka A., Integracja europejska. Od jednego rynku do unii walutowej, C.H.Beck, Warszawa 2004.

Zienkowski L., Gospodarka oparta na wiedzy - mit czy rzeczywistość?, [w:] Wiedza a wzrost gospodarczy, red. L. Zienkowski, Wydawnictwo Naukowe Scholar, Warszawa 2003.

\section{Źródla internetowe}

appsso.eurostat.ec.europa.eu

bg.ae.poznan

cyfronet.krakow.pl

economicprincipals.com

econpapers.repec.org

epp.eurostat.ec.europa.eu

funduszeeuropejskie.gov.pl

hermin.pl

mf.gov.pl

mrr.gov.pl

polskawue.gov.pl

pwt.sas.upenn.edu

stat.gov.pl 


\section{WYKAZ OZNACZEŃ}

\begin{tabular}{|c|c|}
\hline $\mathrm{B} \& \mathrm{R}$ & Badania i Rozwój \\
\hline BAEL & Badanie Aktywności Ekonomicznej Ludności \\
\hline BDL & Bank Danych Lokalnych \\
\hline CEDEFOP & European Centre for the Development of Vocational Training \\
\hline CGE & Computational General Equilibrium \\
\hline CSHM & Cohesion System of HERMIN Models \\
\hline DNB & Dochód Narodowy Brutto \\
\hline DSGE & Dynamic Stochastic General Equilibrium \\
\hline E3ME & Energy-Enviroment-Economy Model of Europe \\
\hline EFOiG & Europejski Funduszy Orientacji i Gwarancji Rolnych \\
\hline EFRR & Europejski Fundusz Rozwoju Regionalnego \\
\hline EFS & Europejski Fundusz Społeczny \\
\hline ESRI & The Economic and Social Research Institute \\
\hline FEM & Fixed Effects Model \\
\hline GEM & Global Economy Model \\
\hline GER & Gross Enrlolment Ratio \\
\hline GFM & Global Fiscal Model \\
\hline GMM & Generalized Method of Moments (Uogólniona Metoda Momentów) \\
\hline GOW & Gospodarka Oparta na Wiedzy \\
\hline GUS & Główny Urząd Statystyczny \\
\hline HERMES & Harmonised Econometric Research for Modelling Economic Systems \\
\hline IBnGR & Instytut Badań nad Gospodarką Rynkową \\
\hline High-tech KIS & $\begin{array}{l}\text { High-tech Knowledge Intensive Services } \\
\text { (Ustugi oparte na zaawansowanej wiedzy) }\end{array}$ \\
\hline IBS & Instytut Badań Strukturalnych \\
\hline ISPA & $\begin{array}{l}\text { Instrument for Structural Policies for Pre-Accesion } \\
\text { (Instrument Przedakcesyjnej Polityki Strukturalnej) }\end{array}$ \\
\hline K_pc & $\begin{array}{l}\text { kapitał na mieszkańca (jeśli nie podano inaczej wartość brutto środków } \\
\text { trwałych w cenach stałych na mieszkańca) }\end{array}$ \\
\hline K_pp & $\begin{array}{l}\text { kapitał na pracującego - techniczne uzbrojenie pracy (jeśli nie podano inaczej } \\
\text { wartość brutto środków trwałych w cenach stałych na pracującego) }\end{array}$ \\
\hline $\mathrm{KE}$ & Komisja Europejska \\
\hline KIS & Knowledge Intensive Services (Ustugi Oparte na Wiedzy) \\
\hline KJO & Krajowa Jednostka Oceny \\
\hline KMNK & Klasyczna Metoda Najmniejszych Kwadratów \\
\hline
\end{tabular}


KŚT Klasyfikacja Śródków Trwałych

MRR

Ministerswo Rozwoju Regionalnego

NPR

Narodowy Plan Rozwoju

NSRO

Narodowe Strategiczne Ramy Odniensienia

PHARE Poland and Hungary Assistance for Restructuring their Economies

NUTS Klasyfikacja Jednostek Terytorialnych do Celów Statystycznych (Nomenclature of Units for Territorial Statistics)

PKB Produkt Krajowy Brutto

PKB_pc Produkt Krajowy Brutto w cenach stałych na mieszkańca

PPP Purchasing Power Parity

PPS Purchasing Power Standard

PSM Propensity Score Matching

REM Random Effects Model

REMI-NET Regional Economic Models

RPO Regionalny Program Operacyjny (w NSRO 2007-2013)

SAPARD Special Accession Programme for Agriculture and Rural Development

SRK

Strategia Rozwoju Kraju (obecnie obowiązująca na lata 2007-2015)

TFP

Łączna Produktywność Czynników Produkcji (Total Factor Productivity)

UE

Unia Europejska

VAR

Vector Autoregressive Model

VECM

Vector Error Correction Model

WARR

Wrocławska Agencja Rozwoju Regionalnego

WBŚT

Wartość Brutto Środków Trwałych

WDB

Wartość Dodana Brutto

WDB_pp

Wartość Dodana Brutto w cenach stałych na pracującego (wg BAEL)

WE

Wspólnota Europejska

WWPR

Wskaźnik Względnego Poziomu Rozwoju

ZPORR

Zintegrowany Program Operacyjny Rozwoju Regionalnego (w NPR 2004-2006) 
Skróty użyte do oznaczenia województw

$\begin{array}{ll}\mathrm{dl} & \text { Dolnośląskie } \\ \mathrm{kp} & \text { Kujawsko-pomorskie } \\ \mathrm{le} & \text { Lubelskie } \\ \mathrm{lb} & \text { Lubuskie } \\ \mathrm{ld} & \text { Lódzkie } \\ \mathrm{mp} & \text { Małopolskie } \\ \mathrm{mz} & \text { Mazowieckie } \\ \text { op } & \text { Opolskie } \\ \mathrm{pk} & \text { Podkarpackie } \\ \mathrm{pd} & \text { Podlaskie } \\ \mathrm{pm} & \text { Pomorskie } \\ \mathrm{sl} & \text { Śląskie } \\ \mathrm{sw} & \text { Świętokrzyskie } \\ \text { wm } & \text { Warmińsko-mazurskie } \\ \text { wk } & \text { Wielkopolskie } \\ \text { zp } & \text { Zachodniopomorskie }\end{array}$




\section{Zalącznik 1}

Rys. 1Z. Podzial zjawiska konwergencji wg różnych kryteriów (por. rozdzial 1.4)

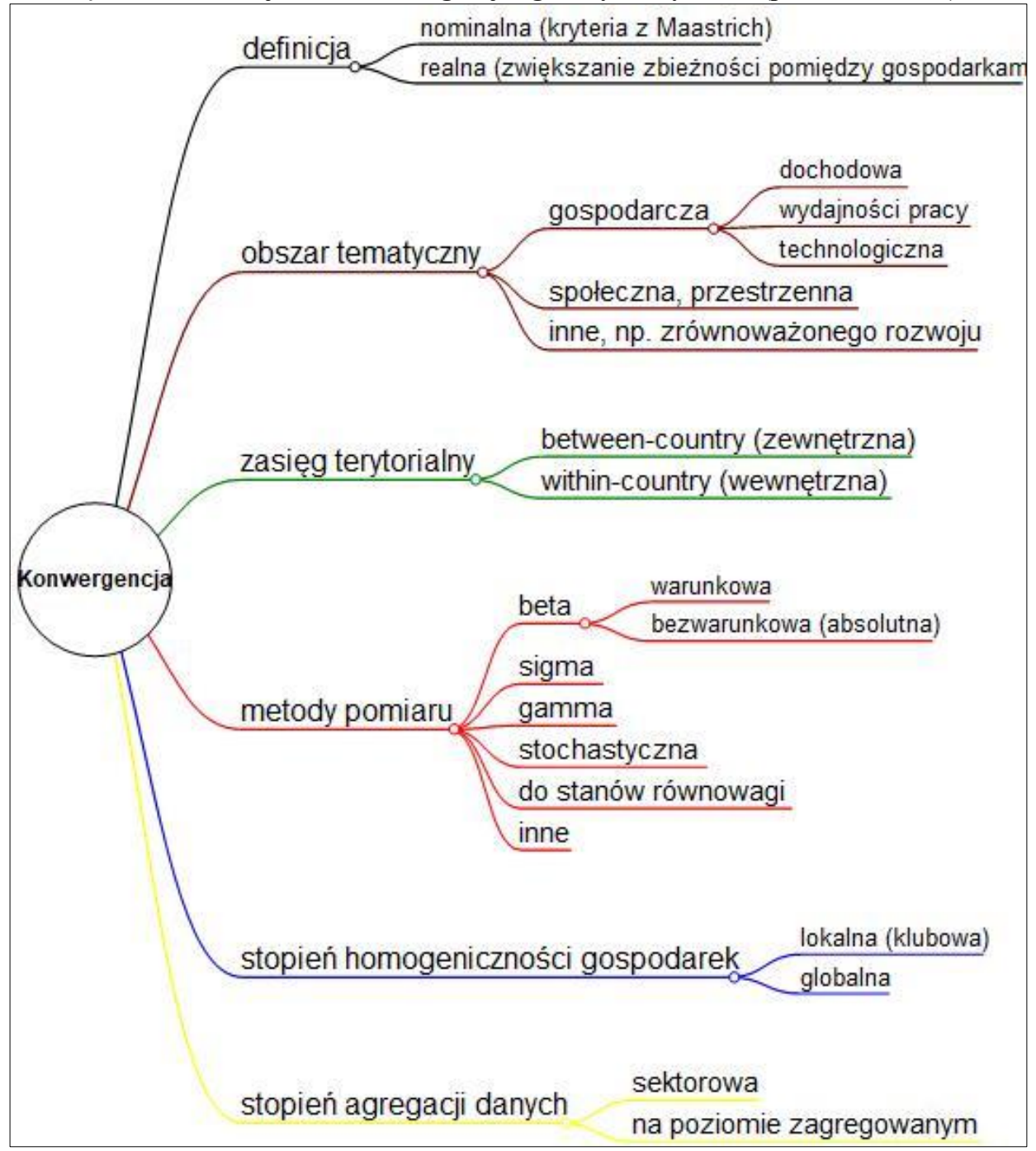

Źródło: opracowanie własne w programie MindMapper 4.0 